\title{
WestVirginiaUniversity
}

THE RESEARCH REPOSITORY @ WVU

Graduate Theses, Dissertations, and Problem Reports

2013

\section{From Gunboats to Good Neighbors: U.S. Naval Diplomacy in Peru, 1919-1942}

Joel C. Christenson

West Virginia University

Follow this and additional works at: https://researchrepository.wvu.edu/etd

\section{Recommended Citation}

Christenson, Joel C., "From Gunboats to Good Neighbors: U.S. Naval Diplomacy in Peru, 1919-1942" (2013). Graduate Theses, Dissertations, and Problem Reports. 253.

https://researchrepository.wvu.edu/etd/253

This Dissertation is protected by copyright and/or related rights. It has been brought to you by the The Research Repository @ WVU with permission from the rights-holder(s). You are free to use this Dissertation in any way that is permitted by the copyright and related rights legislation that applies to your use. For other uses you must obtain permission from the rights-holder(s) directly, unless additional rights are indicated by a Creative Commons license in the record and/ or on the work itself. This Dissertation has been accepted for inclusion in WVU Graduate Theses, Dissertations, and Problem Reports collection by an authorized administrator of The Research Repository @ WVU.

For more information, please contact researchrepository@mail.wvu.edu. 
From Gunboats to Good Neighbors:

U.S. Naval Diplomacy in Peru, 1919-1942

Joel C. Christenson

Dissertation submitted to the

Eberly College of Arts and Sciences

at West Virginia University

in partial fulfillment of the requirements

for the degree of

Doctor of Philosophy

in

History

James F. Siekmeier, Ph.D., Chair

Bradley L. Coleman, Ph.D.

Elizabeth Fones-Wolf, Ph.D.

Jack Hammersmith, Ph.D.

Aaron Sheehan-Dean, Ph.D.

Department of History

Morgantown, West Virginia

2013

Keywords: Peru; naval; diplomacy; inter-war period; Good Neighbor Policy; Intervention; dictatorship

Copyright 2013 Joel C. Christenson 


\section{ABSTRACT \\ From Gunboats to Good Neighbors: \\ U.S. Naval Diplomacy in Peru, 1919-1942}

\section{Joel C. Christenson}

This dissertation examines the role naval power played in the evolution of U.S. policy toward Latin America during the interwar period, when the United States abandoned armed interventionism in favor of the policy of the "Good Neighbor." Specifically, it focuses on two oft-overlooked types of naval diplomacy the United States used to exercise influence in the South American nation of Peru: the employment of U.S. personnel as naval advisers to the Peruvian government, and the use of U.S. naval vessels as agents of public diplomacy on "goodwill" cruises and port visits in Peruvian waters. It argues that the United States relied on the former while interventionism remained the accepted policy toward much of Latin America but was considered untenable south of the Caribbean (roughly 1919-1932), and embraced the latter after renouncing intervention in the interests of becoming a "Good Neighbor" (roughly 1933 through World War II). This research demonstrates that naval power was a much more flexible, integral part of U.S. diplomacy in Latin America during the 1920s and 1930s than historians have recognized. And importantly, it begins to bridge a persistent gap between the literatures on American diplomatic and naval history - neither of which captures the full extent of the nation's efforts at naval diplomacy in the interwar period or adequately addresses the broader significance of those efforts to U.S. foreign relations. 
a mi esposa-eres mi hogar. 


\section{ACKNOWLEDGEMENTS}

All I heard before setting out on this journey was that dissertation is a long, lonely pursuit. In some respects that has proven to be true. At the same time, though, as I wound my way through this project it became joyfully clear to me that no person can complete such a highly individual pursuit alone. It is a shame that this work, and the academic title that comes along with its successful completion, bear only my name - for none of it would have been possible without the support of others.

I would like, first of all, to thank the members of my dissertation committee. Very deep, heartfelt thanks go to Dr. James Siekmeier, who guided this project at every step with kind, patient encouragement. From the time I arrived at WVU in 2008 to today, he has given me support in ways too numerous to recount here. He is the model of what a doctoral advisor should be: coach, advocate, and in the end, dear friend. I am profoundly grateful also to Dr. Bradley Coleman, who introduced me to graduate education in history in the summer of 2005 and who, in the years since, has done me the high favor of demanding absolute excellence from my work at every turn. He has done more than he knows to shape me into the historian that I am today. He is an excellent scholar and teacher, and an ideal mentor. I am blessed to be able to call him amigo. Dr. Elizabeth Fones-Wolf, chair of the WVU Department of History, has helped nurture this project from seminar paper to completed dissertation. I hope one day to repay her generous, unwavering support of my work, and of my professional development. Special thanks are also in order for Dr. Jack Hammersmith and Dr. Aaron Sheehan-Dean, both of whom served thoughtfully and without hesitation on my dissertation committee despite having a thousand commitments of their own. I am grateful for their contributions. 
I would not be where I am today without the unconditional love and support of my Mom and Dad, who instilled in me both a deep love of learning and the confidence to believe that I could overcome all challenges in my path. From my days as a crying Rat at VMI to now, they've proven that parenting never ends. Theirs is the standard to which I aspire in my own walk as a father. I am blessed also to have as in-laws Dennis and Chris Moyer, who, perhaps despite their better judgment, expressed only support when I first mentioned the possibility of taking their daughter to West Virginia to live on a graduate student's stipend. In the years since, they have provided generous moral support and a whole lot of free room and board during my numerous (and sometimes lengthy) research visits to the DC area. Without this support I would never have been able to complete this project.

As this is a project that seeks, in part, to tell a compelling story about the Peruvian Navy, special thanks are in order to two leading authorities on the subject - both of whom were gracious in offering me their valuable perspectives. Dr. Daniel Masterson of the U.S. Naval Academy took time out of his busy schedule to respond thoughtfully to numerous emails, and to talk with me in person about my project. Dr. Jorge Ortíz Sotelo of Peru, a leading voice on Latin American naval history, has been a source of valuable advice and support. I look forward to working with both of these fine scholars in the future.

It is always gratifying when others find one's research not only interesting, but worthy of financial support. I am particularly fortunate to have received funding from a number of excellent institutions. Special thanks go to the U.S. Navy's Naval History and Heritage Command, which honored me with the Rear Admiral John D. Hayes Pre-Doctoral Fellowship in Naval History for the 2011-2012 academic year. The Hayes Fellowship made it possible for me to take some much-needed time off of teaching, and, for a time, to devote 
all of my professional energies to research and writing. The Naval History and Heritage Command is one of the real gems in the federal government's historical establishment. It was my good fortune to receive not only crucial funding from the Command, but thoughtful feedback on my work from its top-notch staff of historians. Dr. Michael Crawford (Senior Historian), Dr. Timothy Francis, and Mr. Robert Cressman all provided helpful direction and criticism along the way. I am profoundly grateful also to Rear Admiral Jay DeLoach, former Director of Naval History, who took an interest in my work at the 2010 annual meeting of the Society for Military History. From our first meeting, he supported my research and opened the doors of NHHC's fantastic resources to me. I appreciate it, and always will.

I offer heartfelt thanks to United States Southern Command, and again to its former Command Historian, Bradley Coleman, for helping to sustain this project through four historical research internships. Through those experiences I learned just how important timely, relevant historical knowledge is to the world of contemporary policymaking and military operations - especially in the American "neighborhood." Thanks go also to the WVU Department of History, which supported my research with a departmental dissertation fellowship as this project wound its way toward a productive conclusion. I also owe a significant debt of gratitude to the Franklin and Eleanor Roosevelt Institute (Hyde Park, New York) and the Herbert Hoover Presidential Library Association (West Branch, Iowa), both of which awarded me grants-in-aid to conduct invaluable research in the Roosevelt and Hoover libraries, respectively.

Good, patient archivists are a blessing to every historian who has ever felt overwhelmed stepping into the world of primary source research. At the National Archives in Washington, DC and College Park, Maryland, I have benefitted from the wise counsel of 
Mr. David Langbart (diplomatic records), Mr. Mark Mollan (navy records, downtown DC), and Mr. Nate Patch (navy records, College Park). Mr. Matt Schaefer at the Herbert Hoover Presidential Library in West Branch, Iowa, made my visit there more productive than I could have hoped. His kind assistance, both in person and, in the months after my visit, by email, has been invaluable. Mr. John Greco of the Naval History and Heritage Command's Operational Archives provided friendly, valuable archival support during my numerous visits to the Navy Yard.

The WVU Department of History is a special place, filled with special people who helped make my doctoral studies a joy. Outside of those faculty I have already mentioned, I feel particularly blessed to have had the opportunity to work with Dr. Peter Carmichael, who, more than anyone else, drove home to me the very valuable truth that what one sees as a historian depends on where one sits. It took all the scholarly energy I could muster to avoid being completely taken in by Civil War history while studying under his direction. Also, Dr. SilverMoon made my exploration of colonial and post-colonial Latin American history a pleasure. I miss her counsel. Special thanks are due also to Martha May and Becky Warnke of the History Department's staff. They answered every question I ever asked with patience and professionalism, and went the extra mile for me on more than a few occasions. The Department is lucky to have them.

If one's friends are the measure of one's experiences, my time at WVU has been exceptional. Special thanks go to Josh Esposito, with whom I share a love of history, football, and good IPA. He is one great amigo, and I am excited to see where his excellence as a scholar and teacher takes him. Golf outings with Joe Rizzo and Jordan Lieser provided much-needed diversions from the rigors of teaching and writing during the few months of 
each school year when West Virginia weather permitted them. Brandon Williams kept all in our cohort laughing, finding the funny in every situation. He has an amazing gift for it. Cara Snider's pure joie de vivre was - and is - an inspiration. David Goldberg and Billy Feeney were both generous and patient in sharing their expertise on the Civil War and Reconstruction - as well as their inexhaustible knowledge on Bruce Springsteen and coffee, respectively. Karina Garcia kept me supplied with decaf coffee and good cheer. For their friendship, I also wish to thank Jake Struhelka, Kati Engel, Jamie Bonser, Steve Wismer, Hal Gorby, Jinny Turman, Lauren Thompson, Ginny Young, Steve Santelli, and Rich Hulver. Each enriched my time at WVU in special and unique ways.

To say that my deepest thanks go to my beautiful wife, Emily, is to say far, far too little. At every step along this very long journey, she gave me unconditional love and constant support and encouragement. She spent far too much of our time in Morgantown alone - while I was traveling for research and conferences, and, more often, when I was holed up in my basement office studying for comps, grading, preparing lectures, or writing for months on end. All the while, she built a thriving business and became the kind of mother every man dreams that his child could have. I don't know that I can ever make up for all she has given, but now it is my turn to try. A special word of thanks goes also to my son, Teddy. Although he is too young to really understand what Daddy's been up to this whole time, when he is older I want him to know that the pitter-patter of his little feet on the floor above, and the sound of his laughter (and yes, of his crying) helped get his Daddy through some really challenging times. His arrival in 2010 was a blessing, and he is a source of true joy in my life. This work is for him, and for his wonderful Mommy. 


\section{CONTENTS}

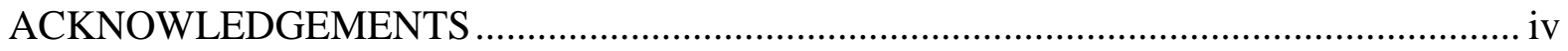

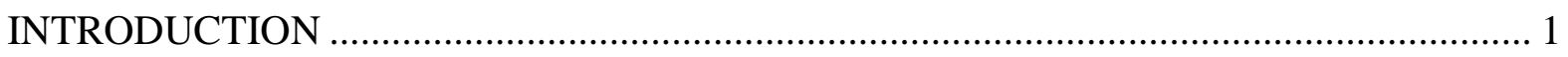

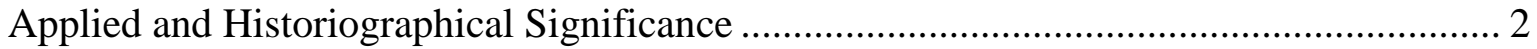

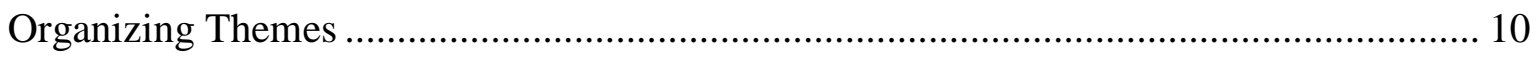

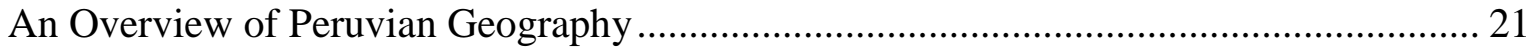

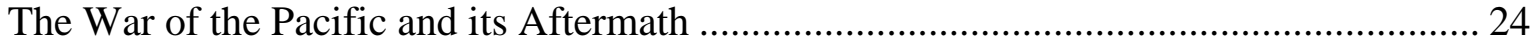

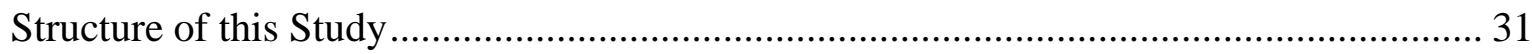

CHAPTER 1: A CONVERGENCE OF INTERESTS, 1919-1921 ..................................... 33

Looking South: U.S. Interests After the First World War ............................................ 34

Peruvian Interests: Financial and Trade Ties ............................................................. 40

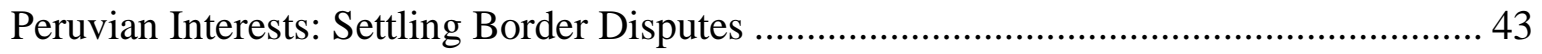

Peruvian Interests: Establishing a Dictatorship.......................................................... 56

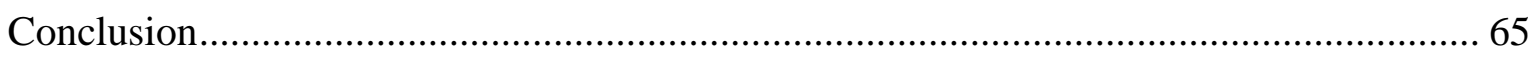

CHAPTER 2: THE WORK OF THE U.S. NAVAL MISSION TO PERU, 1920-1930....... 68

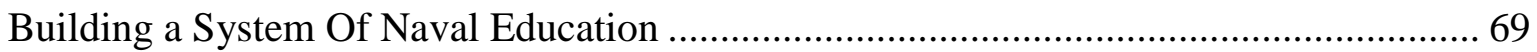

Establishing a Modern Submarine Force ........................................................... 82

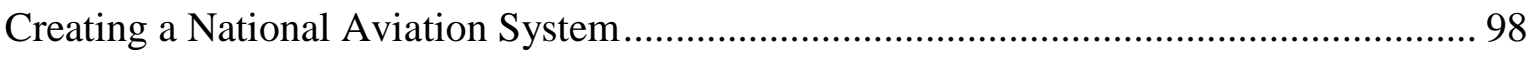

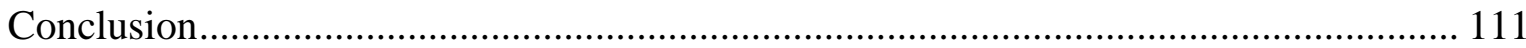

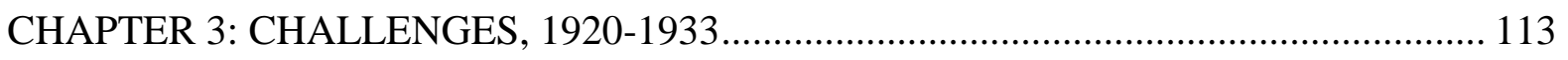

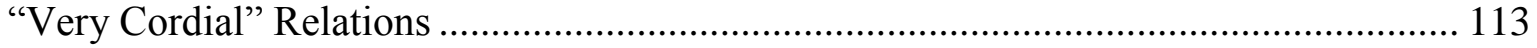

Challenges: The Woodward Incident ................................................................ 122

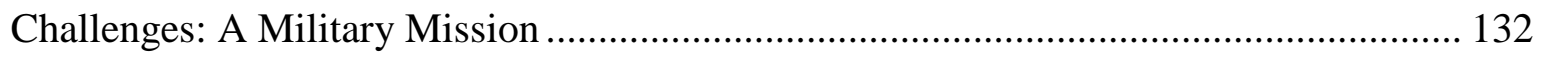

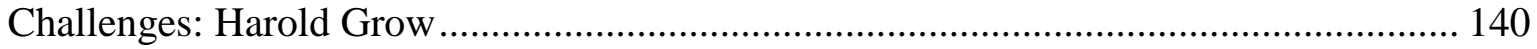

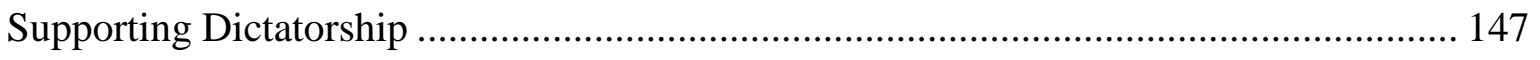

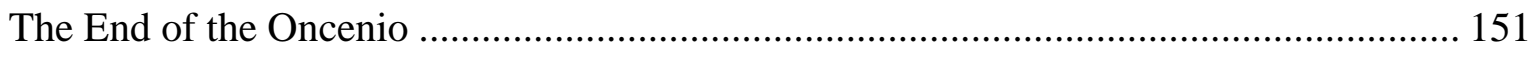

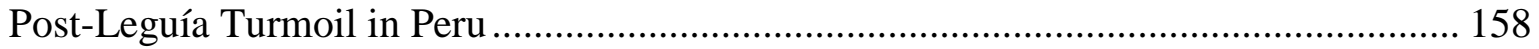

The End of the U.S. Naval Mission ................................................................ 167

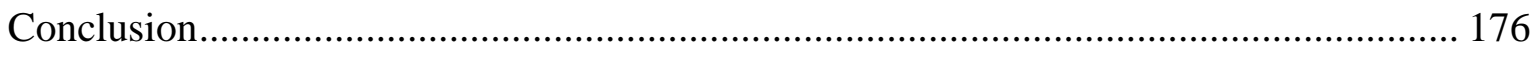

CHAPTER 4: A NEW NAVAL DIPLOMACY, 1928-37 ............................................ 178 


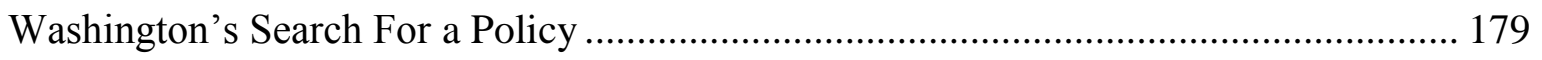

Goodwill Naval Diplomacy Before the Good Neighbor.................................................. 184

Herbert Hoover's Goodwill Tour................................................................................. 190

Under FDR: The U.S. Navy as a Good Neighbor.......................................................... 200

Balancing Gunboats and Goodwill: The Special Service Squadron ................................ 210

Goodwill Cruising in Peru....................................................................................... 215

Growing Concerns Over Hemispheric Security ……………………………………..... 227

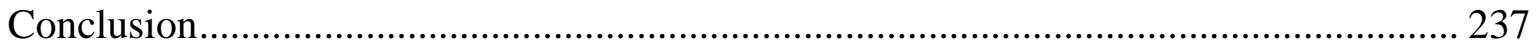

CHAPTER 5: NAVAL DIPLOMACY IN HEMISPHERIC DEFENSE, 1937-1942........... 239

Reestablishing the U.S. Naval Mission to Peru ……………………………………...... 240

The Naval Mission and Hemispheric Defense ………………………………………..... 253

Goodwill Cruising and Hemispheric Defense.............................................................. 268

A Deepening Security Partnership ........................................................................ 275

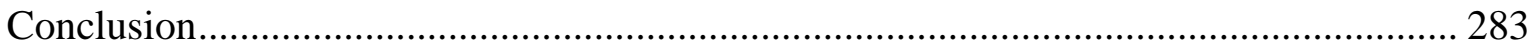

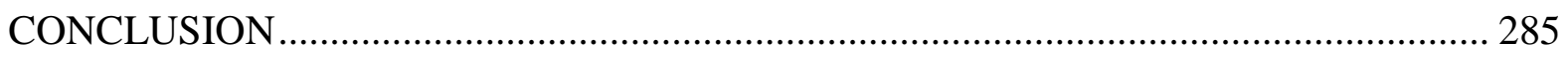

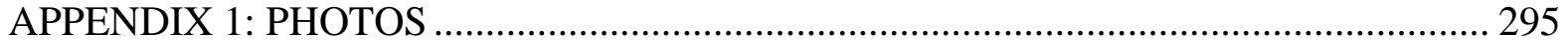

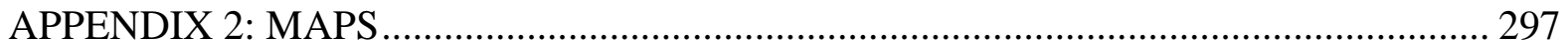

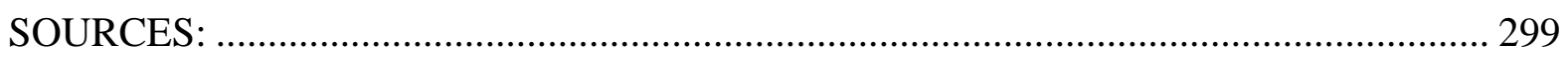




\section{INTRODUCTION}

This dissertation examines the considerable role naval power played in United States foreign relations with the South American nation of Peru from the 1920s to the early 1940s, a period when Washington abandoned the practice of armed intervention in its hemispheric policy in favor of what President Franklin D. Roosevelt called "the policy of the good neighbor." "Specifically, it focuses on two types of non-coercive naval diplomacy the United States used in Peru during those years to help move its Latin American policy to a more sustainable non-interventionist basis. First, it examines the American commitment to send a team U.S. Navy personnel to Peru as advisers (known as a naval mission) on naval affairs. Second, it explores the frequent employment of U.S. naval vessels and personnel in highly visible cruises and port visits to Peruvian waters for the purpose of cultivating goodwill. Both activities were central, this dissertation argues, to American efforts to close a turbulent period in the early twentieth century - a time when the relations of the United States with its southern neighbors turned on the use of force, actual and threatened. Peru provides an appropriate focal point for such a study of the interwar policy of the United States toward Latin America because, geographically, it falls outside of the Caribbean zone where the United States had long relied on intervention, and because, unlike countries of South America's east coast and southern cone, as an Andean nation on the continent's west coast Peru did not have socioeconomic or cultural ties with Europe strong enough to preclude it

\footnotetext{
${ }^{1}$ In his first inaugural address in March, 1933, Roosevelt declared that "In the field of world policy I would dedicate this Nation to the policy of the good neighbor - the neighbor who resolutely respects himself and, because he does so, respects the rights of others - the neighbor who respects his obligations and respects the sanctity of his agreements in and with a world of neighbors." Although it was a general declaration intended to guide U.S. relations throughout the world, the "Good Neighbor Policy" soon became associated most closely with Latin America. See Franklin D. Roosevelt and Samuel I. Rosenman, The Public Papers and Addresses of Franklin D. Roosevelt, 13 vols., vol. 2 (New York: Russell \& Russell, 1969), 14.
} 
from developing a closer association with the United States. In short, during the interwar

period U.S. foreign policymakers viewed Peru as something of a clean slate, on which it would be possible to chart a new, less antagonistic course for U.S.-Latin American relations. ${ }^{2}$

It was in Peru during these years, this dissertation contends, that U.S. foreign policy made use of naval power to help alter the direction of its relations with Latin America. It is necessary, therefore, to understand American naval diplomacy in Peru in order to comprehend how U.S. policy in Latin America began moving "from gunboats to good neighbors."

\section{APPLIED AND HISTORIOGRAPHICAL SIGNIFICANCE}

This dissertation's focus on the intersection of foreign relations and naval affairs makes it timely and relevant. More than any other arm of national military power, the work of a nation's navy is intimately connected with its foreign policy. This is true because, as naval theorist Ken Booth notes, warships routinely perform far more than fighting functions in the service of nations" interests: they are "visible signifiers and representatives of a country's intentions and commitments," he writes, a fact that makes them valuable adjuncts

\footnotetext{
${ }^{2}$ All studies of U.S. relations with Latin American nations have to confront the challenge posed by the usage of the words "America," "Americas," and "American." In this study, I use the words "United States" and "America" interchangeably, and I use the word "American" to refer to people, ideas, policies, and possessions that have their origins in the United States. I do this not out of cultural insensitivity, but because, of all the peoples of the Western Hemisphere, only citizens of the United States refer to themselves, their ideas, and their national possessions as "American." Often, I use the word "Washington" interchangeably with "United States" when referring to decisions taken or policies pursued by the United States toward Latin America. I use the phrases "Latin America" and "Latin American" to refer to the nations of the Western Hemisphere south of the United States and their peoples. I do not refer to Latin American peoples in this study as "American," because citizens of Latin American nations refer to themselves by their respective nationalities - Peruvian, Chilean, Cuban, and so on. I do, however, use the word "Americas" to refer to the nations inhabiting the Western Hemisphere. For a succinct summary of the logic underlying these choices in nomenclature, see Lester D. Langley, America and the Americas: The United States in the Western Hemisphere, The United States and the Americas (Athens: University of Georgia Press, 1989), xvi-xix.
} 
to foreign policy. ${ }^{3}$ Navies can undertake diplomatic tasks that are difficult if not impossible for ground and air forces to perform because, unlike those forces, naval ships possess the capability to operate independently of large foreign bases for prolonged periods of time. Moreover, because of their range and independence relative to armies and air forces, naval vessels possess a unique capability to respond quickly to crisis situations.

Plying the seventy-one percent of the globe covered by the oceans, naval forces have long been just this kind of asset to the foreign policy of the United States. Indeed, throughout its history the U.S. Navy has fulfilled a number of political, social, and humanitarian functions - functions short of war - in support of American national policy. ${ }^{4}$ For example, from the years of the early republic throughout the nineteenth century, the U.S. Navy devoted most of its peacetime attention to protecting the flow of American commerce overseas. $^{5}$ In the early twentieth century, as it grew in size and complexity to accommodate expanding U.S. interests in the world, the Navy routinely engaged in intervention operations (known as "gunboat diplomacy") to quell unrest in Latin America and East Asia. ${ }^{6}$ During the Cold War, when not rendering wartime service, U.S. ships often engaged in contingency operations of a diplomatic nature, such as staging a blockade in the Caribbean in 1962 to

\footnotetext{
${ }^{3}$ Ken Booth, Navies and Foreign Policy (London, New York: Croom, Helm, Crane, Russak, 1977), 34-35.

${ }^{4}$ The seventy-one percent figure comes from the U.S. National Oceanic and Atmospheric Administration. (NOAA). See NOAA, "Ocean." Accessed February 10, 2013. http://www.noaa.gov/ocean.html.

${ }^{4}$ For more on the U.S. Navy's role supporting American commerce in the nineteenth century, see John H. Schroeder, Shaping a Maritime Empire: The Commercial and Diplomatic Role of the American Navy, 18291861 (Westport: Greenwood Press, 1985).

${ }^{5}$ For more on the U.S. Navy's role supporting American commerce in the nineteenth century, see ibid.

${ }^{6}$ On U.S. gunboat diplomacy in Latin America in the early twentieth century, see Donald A. Yerxa, Admirals and Empire: The United States Navy and the Caribbean, 1898-1945 (Columbia: University of South Carolina Press, 1991). On similar operations in China in the early twentieth century, see Kenneth J. Hagan, This People's Navy: The Making of American Sea Power (New York: Free Press, 1991), 193-280.
} 
disrupt the flow of Soviet nuclear weapons and delivery systems to the island of Cuba. ${ }^{7}$ And, as has become routine in recent years, American naval ships have conducted cruises in friendly waters aimed at providing medical care to foreign populations and providing humanitarian relief. ${ }^{8}$ Indeed, it is fair to say that the U.S. Navy, which has not fought a major naval battle (a fleet action) since 1944, has devoted more time and effort to essentially diplomatic missions over the past seven decades than it has to conducting combat operations. ${ }^{9}$ This reality makes the Navy's role in U.S. diplomacy a fruitful area for study. The utility of navies to foreign policy is not limited to the global reach of ships and hardware, however. It stems also from the diplomatic nature of naval officership. Throughout American history, to a much greater degree than personnel from other military services, naval officers have served as de facto U.S. diplomats overseas. ${ }^{10}$ This is especially true in Latin America, where in the early twentieth century naval personnel frequently led intervention and occupation operations, and where, since 1920, the United States has dispatched naval personnel to advise foreign governments in naval affairs. ${ }^{11}$ Initially a niche arrangement extended to only a handful of Latin American countries, U.S. naval advising in the Americas grew considerably during World War II as the United States stepped up efforts

\footnotetext{
${ }^{7}$ See Curtis A. Utz, Cordon of Steel: The U.S. Navy and the Cuban Missile Crisis, The U S Navy in the Modern World Series (Washington: Naval Historical Center, 1993).

${ }^{8}$ See James Stavridis, Partnership for the Americas: Western Hemisphere Strategy and U.S. Southern Command (Washington, D.C.: National Defense University Press, 2010).

${ }^{9}$ For an excellent recent treatment of the last major (fleet-level) U.S. naval battle, the Battle of Leyte Gulf (October, 1944), see H. P. Willmott, The Battle of Leyte Gulf: The Last Fleet Action (Bloomington: Indiana University Press, 2005).

${ }^{10}$ David F. Long, Gold Braid and Foreign Relations: Diplomatic Activities of U.S. Naval Officers, 1798-1883 (Annapolis: Naval Institute Press, 1988).

${ }^{11}$ Among the most notable, high profile naval officers to write about his experiences as a "gunboat diplomat" during this period was Rear Admiral William B. Caperton, whose unpublished memoir discusses the diplomatic nature of early twentieth century naval officership at great length. See William Banks Caperton, History of Flag Career of Rear Admiral W.B. Caperton, U.S. Navy, Commencing January 5, 1915, RG 45, ZN Box 936, National Archives.
} 
to improve hemispheric defenses. This wartime initiative had not only the strictly military aim of improving Latin American proficiency in national defense, but also the diplomatic objective of helping to forge an anti-Axis unity throughout the Americas consistent with U.S. security aims. The United States remained heavily involved in naval advising in the post-war years as the triumph of victory over the Axis Powers gave way to deep new tensions with the Soviet Union. During the Cold War, when the United States made fighting communism a priority of its inter-American policy, U.S. naval and military advising were important parts of its inter-American policy. ${ }^{12}$ This presence endures today, as naval advisers serve together with Army, Air Force, and Marine Corps personnel in joint Military Groups (known as "MilGroups") throughout Latin America that establish and maintain military-to-military contacts with partner nations, provide advice to those nations' military establishments, and coordinate bilateral and multilateral military training and exchange programs. ${ }^{13}$ The persistence of the practice of U.S. naval and military advising, and its important place in U.S.-Latin American relations, make it a fertile area for historical inquiry, as well.

This research is historiographically significant, as well. It helps to bridge a persistent gap between the literatures on American naval and foreign relations history, neither of which fully recognizes the important role naval power played in U.S. policy toward Latin America during the 1920s, 1930s, and 1940s. In this way, this dissertation is responsive to recent calls of scholars of diplomatic and military history for a deeper, more nuanced conversation

\footnotetext{
${ }^{12}$ See Edward C. Stewart, "American Advisors Overseas," Military Review 45, no. 2 (1965): 3-9.

${ }^{13}$ See Tony Payan, Cops, Soldiers, and Diplomats: Explaining Agency Behavior in the War on Drugs (Lanham: Lexington Books, 2006), 100-01. For more on the expansion of U.S. military and naval advising in Latin America during the early Cold War, see Robert O. Kirkland, Observing Our Hermanos de Armas: U.S. Military Attachés in Guatemala, Cuba, and Bolivia, 1950-1964, Latin American Studies: Social Sciences and Law (New York, N.Y.: Routledge, 2003).
} 
between the two fields. ${ }^{14}$ Scholars of American naval history have generally devoted little attention to the activities of the U.S. Navy in Latin America during this period, instead focusing their attention on those decades' broader innovations in maritime strategy and on bureaucratic fights over the size, structure, and distribution of the U.S. fleet. ${ }^{15}$ Naval historians who have addressed the Navy's role in U.S. diplomacy have either not placed significant attention on the Americas, or have focused their inquiries on earlier chronological periods. ${ }^{16}$ Those few who have examined U.S. naval diplomacy in Latin America during the interwar period have, meanwhile, largely confined their inquiries to the Caribbean area that bore the brunt of U.S. "gunboat diplomacy" interventions, and say little about the

\footnotetext{
${ }^{14}$ Thomas Zeiler et al., "The Convergence of Military and Diplomatic History: A Roundtable," Passport: Newsletter of the Society for Historians of American Foreign Relations (2012): 30-37.

${ }^{15}$ For example, Edward J. Marolda's edited volume of essays by leading figures in U.S. naval history contains pieces entitled "FDR at War, 1913-1921," "Franklin D. Roosevelt and Naval Strategy, 1933-1941," and "The Evolution of the U.S. Fleet, 1933-1941: How the President Mattered." See Edward J. Marolda, FDR and the U.S. Navy, 1st ed., The Franklin and Eleanor Roosevelt Institute Series on Diplomatic and Economic History (New York: St. Martin's Press, 1998). In his history of U.S. sea power from 1890 to 1990, George W. Baer briefly addresses the importance of Latin America to U.S. strategists during World War II, but says nothing of naval advising or goodwill cruising in the Western Hemisphere. See George W. Baer, One Hundred Years of Sea Power: The U.S. Navy, 1890-1990 (Stanford: Stanford University Press, 1994). The same is true of Kenneth Hagan's classic one-volume history of American sea power from the American Revolution through 1990. See Hagan, This People's Navy: The Making of American Sea Power. Robert G. Albion's classic study of naval policy is similarly silent on the Navy's role in U.S. diplomacy in Latin America between the world wars. See Robert Greenhalgh Albion and Rowena Reed, Makers of Naval Policy, 1798-1947 (Annapolis: Naval Institute Press, 1980). Peter Karsten's study of the U.S. Navy officer corps in the 19th and early 20th centuries contains one chapter on the Navy's role in U.S. diplomacy, but devotes only eight pages to Latin America and the Caribbean - most of which, for the period in question, address U.S. gunboat diplomacy in the Caribbean. See Peter Karsten, The Naval Aristocracy: The Golden Age of Annapolis and the Emergence of Modern American Navalism, 1st Naval Institute Press (Annapolis: Naval Institute Press, 2008).

${ }^{16}$ Richard Challener's study of the U.S. Navy's role in foreign policy worldwide focuses its Latin American attention gunboat diplomacy operations in the Caribbean from 1898 to 1914. See Richard D. Challener, Admirals, Generals, and American Foreign Policy, 1898-1914 (Princeton: Princeton University Press, 1973). Charles Oscar Paullin's landmark work on the diplomatic activities of U.S. naval officers, the first study to treat the topic, was written in 1912 and covers the period 1778 to 1883. See Charles Oscar Paullin, Diplomatic Negotiations of American Naval Officers, 1778-1883 (Baltimore: Johns Hopkins Press, 1912). David F. Long's effort to update Paullin's work retains his chronological scope, ending in 1883. See Long, Gold Braid and Foreign Relations: Diplomatic Activities of U.S. Naval Officers, 1798-1883. William R. Braisted has done innovative work on the diplomatic roles of U.S. Naval officers in China in the interwar period, but there is no comparable work that sheds light on the vital diplomatic roles that Naval officers played in Latin America. See William Reynolds Braisted, Diplomats in Blue: U.S. Naval Officers in China, 1922-1933, New Perspectives on Maritime History and Nautical Archaeology (Gainesville: University Press of Florida, 2009).
} 
employment of naval power south of the Caribbean, where U.S. policy had long deemed

armed intervention to be impractical. ${ }^{17}$ These studies provide little analysis of the U.S.

Navy's active agenda of goodwill cruising in South American waters during the period, and

are silent on the advising work undertaken by U.S. naval missions in Peru and other countries

throughout the period. ${ }^{18}$ This dissertation is offered as a partial corrective to these

deficiencies in U.S. naval historiography.

Historians of U.S. foreign relations in the Western Hemisphere during the interwar

period have likewise said little about the significance of naval power to U.S. diplomacy. ${ }^{19}$

Scholars of U.S.-Latin American relations whose studies focus on U.S. armed interventions,

the turn in U.S. foreign policy toward "good neighborism," and the role of cultural

interaction in that shift have generally not acknowledged the considerable importance naval power played in bringing about that transformation. ${ }^{20}$ Among the only works of foreign

17 Richard Millett has produced excellent work on the Navy's Special Service Squadron, the unit established in 1920 to patrol Central American and Caribbean waters. See Richard Millett, "The State Department's Navy: A History of the Special Service Squadron, 1920-1940," The American Neptune 35 (1975): 118-135. Donald Yerxa has done a broader study of the U.S. Navy in the Caribbean from the outbreak of the Spanish-American War through World War II, but says little about the Navy's consequential involvement in affairs further south. See Yerxa, Admirals and Empire: The United States Navy and the Caribbean, 1898-1945.

${ }^{18}$ Yerxa mentions the few cruises that ships of the Special Service Squadron made to countries in the northern half of South America, but does not address the many more goodwill cruises the Navy sent throughout South America on maiden test voyages, known as shakedown cruises. See Yerxa, Admirals and Empire: The United States Navy and the Caribbean, 1898-1945, 86-90.

${ }^{19}$ Landmark works on U.S.-Latin American relations in the interwar period that largely overlook naval diplomacy include: Samuel Flagg Bemis, The Latin American Policy of the United States (New York: Harcourt, 1943). Bryce Wood, The Making of the Good Neighbor Policy (New York: Columbia University Press, 1961).

Lloyd C. Gardner, Economic Aspects of New Deal Diplomacy (Madison: University of Wisconsin Press, 1964). Fredrick B. Pike, FDR's Good Neighbor Policy: Sixty Years of Generally Gentle Chaos, 1st ed. (Austin: University of Texas Press, 1995). Robert Dallek's classic history of Roosevelt's diplomacy briefly treats Roosevelt's shipbuilding program and his own 1934 cruise through the Caribbean, the Panama Canal, and into the Pacific (86-91), but does not discuss his administration's use of naval diplomacy in South America. Robert Dallek, Franklin D. Roosevelt and American Foreign Policy, 1932-1945: With a New Afterword (New York: Oxford University Press, 1995).

${ }^{20}$ For example, see: David Healy, Drive to Hegemony: The United States in the Caribbean, 1898-1917 (Madison: University of Wisconsin Press, 1988). Mary A. Renda, Taking Haiti: Military Occupation and the Culture of U.S. Imperialism, 1915-1940 (Chapel Hill: University of North Carolina Press, 2001). Emily S. Rosenberg, Financial Missionaries to the World: The Politics and Culture of Dollar Diplomacy, 1900-1930 
relations history that does address American naval diplomacy in the hemisphere during this period, Eric Roorda's superb study of U.S. relations with dictator Rafael Trujillo's Dominican Republic, is necessarily limited in scope to the Caribbean. ${ }^{21}$ No diplomatic histories of inter-American relations address the Navy's engagement in goodwill cruising during the years of the "Good Neighbor Policy" under the Franklin D. Roosevelt administration. Moreover, none recognize in this activity the origins of U.S. public diplomacy in Latin America, something most place either during World War II or the early Cold War. ${ }^{22}$ And aside from a brief recognition by Joseph Tulchin that the Woodrow Wilson administration sent a U.S. naval mission to Peru in 1920 for essentially diplomatic reasons, scholars of U.S. foreign relations history have also been largely silent on the service of U.S. Navy personnel in advisory missions in Latin America during the 1920s, 1930s, and 1940s. ${ }^{23}$ As a work of U.S. foreign relations history as well as of naval history, then, this study endeavors to demonstrate the centrality of these activities to the course of U.S. interAmerican policy during this period.

Studies in Latin American history have devoted greater attention to military and naval aspects of U.S.-Latin American relations. The landmark work in this regard is Robert L. Scheina's masterful, broad study of Latin American naval history, Latin America: A Naval History, 1810-1987, which contains a brief chapter on foreign naval missions in South

(Cambridge: Harvard University Press, 1999). Kristin L. Hoganson, Fighting for American Manhood: How Gender Politics Provoked the Spanish-American and Philippine-American wars, Yale Historical Publications (New Haven: Yale University Press, 1998).

${ }^{21}$ See Eric Roorda, The Dictator Next Door: The Good Neighbor Policy and the Trujillo Regime in the Dominican Republic, 1930-1945, American Encounters/Global Interactions (Durham: Duke University Press, 1998), 149-91.

22 Justin Hart, Empire of Ideas: The Origins of Public Diplomacy and the Transformation of U.S. Foreign Policy (Oxford: Oxford University Press, 2013).

${ }^{23}$ Joseph S. Tulchin, The Aftermath of War: World War I and U.S. Policy Toward Latin America (New York: New York University Press, 1971), 35. 
America between the world wars, but which, because of its breadth and careful attention to the institutional development of Latin American navies, does not fully analyze the significance of those missions' work to foreign relations. ${ }^{24}$ In its brief four-page treatment of the U.S. naval mission to Peru during the 1920s, Lawrence Clayton's 1999 contribution to the University of Georgia Press's landmark “United States and the America” series, Peru and the United States: The Condor and the Eagle, does recognize the mission's significance to diplomacy between Peru and the United States. Clayton's work, however, focuses intently on the mission's contributions to Peruvian aviation (certainly an important contribution) and does not address the broad, diplomatically significant work the mission did for nearly a decade to directly overhaul other elements of the Peruvian Navy. ${ }^{25}$ The best treatments available on U.S. naval missions in Latin America come, not surprisingly, from a Latin American scholar. Jorge Ortiz Sotelo, a retired Peruvian naval officer and scholar of naval history, has written superb accounts of the work done by the U.S. naval mission to Peru during the 1920s. Much of Ortiz's work concentrates on naval education reforms directed by the U.S. mission at the Escuela Naval, Peru's naval academy. ${ }^{26}$ In addition, he has produced work (published in Peru in the Spanish language) that sheds light on the development of the Peruvian Navy's submarine force and other reforms enacted under U.S. oversight during

\footnotetext{
${ }^{24}$ Robert L. Scheina, Latin America: A Naval History, 1810-1987 (Annapolis: Naval Institute Press, 1987), $127-42$.

${ }^{25}$ Clayton's analysis provides the best point of entry available anywhere for scholars interested in learning about the role of Harold B. Grow (Commander, U.S. Navy) in the development of Peruvian naval and commercial aviation. See Lawrence A. Clayton, Peru and the United States: The Condor and the Eagle, The United States and the Americas (Athens: University of Georgia Press, 1999), 127-31.

${ }^{26}$ Ortiz has made contributions in both the Spanish and English languages. In Spanish, see Jorge Ortíz Sotelo, Escuela Naval del Perú: Historia Ilustrada (La Punta-Callao: Escuela Naval del Perú, 1981). In English, see Ortíz Sotelo, "Captain Davy and the U.S. Naval Mission in Peru, 1920-1930," in New Interpretations in Naval History: Selected Papers from the Ninth Naval History Symposium held at the United States Naval Academy, 18-20 October, 1989, ed. William R. Roberts and Jack Sweetman (Annapolis: Naval Institute Press, 1991).
} 
those years. ${ }^{27}$ Ortiz's work is remarkable not only for its attention to the specific labors of the naval mission in Peru during the 1920s, but because it situates that work in the flow of Peru's domestic politics. ${ }^{28}$ However, neither Ortiz's work nor the work of other scholars operating within the vein of Latin American history places explicit focus on U.S. naval missions' significance to the course of U.S.-Latin American relations during Washington's transition from interventionism to good neighborism in the interwar period. This dissertation seeks to draw out that important connection, and in so doing, make a valuable contribution to Latin American historiography as well.

\section{ORGANIZING THEMES}

Several themes flow throughout this dissertation and form its analytical backbone.

First, it raises questions about the nature and development of U.S. empire in the Western Hemisphere in the twentieth century. Throughout its history, the United States has sought to influence the shape and character of inter-American relations. In the early years of their nation's adolescence, for example, Americans saw their own successful revolution against Great Britain as an example for other nations of the hemisphere struggling for freedom from

\footnotetext{
${ }^{27}$ On the mission's support for developing a modern submarine force in the Peruvian Navy, see Ortíz Sotelo, Apuntes Para la Historia de los Submarinos Peruanos (Lima: Biblioteca Nacional del Perú y Asociación de Historia Marítima y Naval Iberoamericana, 2001).

${ }^{28}$ For example, see Ortíz Sotelo, "Las Rebelliones Navales del Callao, 1932 y 1948," Apuntes 45, Segundo Semestre (1999): 83-95. Daniel Masterson's excellent analysis of Peruvian civil-military relations from the early 1930s through the 1980s provides a very brief overview of the U.S. naval mission to Peru as part of its treatment of the Leguía era, drawing on primary and secondary sources referenced throughout this dissertation. Ortiz's work, although not cited, was important as well. In his preface, Masterson thanks "a Peruvian armed forces officer [Ortiz] who must remain anonymous" due to the unsettled political conditions that prevailed in Peru when the book was published in 1991. See Daniel M. Masterson, Militarism and Politics in Latin America: Peru from Sánchez Cerro to Sendero Luminoso, Contributions in Military Studies (New York: Greenwood Press, 1991), 30-34.
} 
European imperialism. ${ }^{29}$ In 1823 U.S. President James Monroe was sufficiently impressed by his nation's position in the Americas that he unilaterally declared the Western Hemisphere off limits to further European colonization, staking a claim to hemispheric leadership. The United States remained an ambitious but strategically weak force in hemispheric affairs into the late nineteenth century, when, strengthened by an industrial boom, Washington began to stake a more active claim to leadership. In 1889 the United States convened the First International Conference of American States in Washington, a meeting that produced landmark economic agreements and laid a foundation for closer cultural links throughout the Americas. ${ }^{30}$

Americans looked anew at their neighbors to the south in the early twentieth century, increasingly convinced that maintaining a growing, vibrant economy at home required them to take a more active role in managing affairs in Latin America. That emerging consensus grew stronger for military-strategic reasons after the United States began construction on an inter-oceanic canal across Panama in 1904. Upon its completion in 1914, protection of the Panama Canal would become a central organizing principle of U.S. national defense, confirming that Central America and the Caribbean were the heart of the new American empire. ${ }^{31}$ U.S. President Theodore Roosevelt underscored this strategic reality in articulating

\footnotetext{
${ }^{29}$ For more on the United States and Latin American wars for independence from Spain, see Langley, America and the Americas: The United States in the Western Hemisphere, 31-52. Also, see Langley's more recent work on the topic, Langley, The Americas in the Age of Revolution, 1750-1850 (New Haven: Yale University Press, 1996).

${ }^{30}$ Blaine had sought the establishment of an inter-American customs union to grow U.S. exports to Latin America. The meeting did not produce one, but did set the stage for the creation of a Pan-American Highway System, as well as a reciprocity tariff that allowed certain Latin American products to enter the U.S. free of charge in exchange for similarly favorable treatment for U.S. products. See David Healy, James G. Blaine and Latin America (Columbia: University of Missouri Press, 2001), 138-59.

${ }^{31}$ Many interpretations of U.S. Latin American policy in the early 20th century dwell on economic concerns, but David Healy's work presents a balanced picture in which security concerns were paramount, as well. See Healy, Drive to Hegemony: The United States in the Caribbean, 1898-1917. For more on the imperative of
} 
his December 1904 "Corollary" to the Monroe Doctrine, which declared that American interests in the region were so important that the United States would employ military force to protect them if necessary. ${ }^{32}$ It was a turning point in U.S. relations with the nations of Latin America, in the Caribbean basin and beyond. In subsequent years, Roosevelt and his successors - Republican and Democrat alike - demonstrated a firm resolve to uphold this commitment. Between 1900 and 1919, the United States deployed military forces to intervene in its new Caribbean empire on twenty-six different occasions to protect U.S. interests and enforce order. ${ }^{33}$ The era of American "gunboat diplomacy" had begun. ${ }^{34}$

The high costs of World War I, both in blood and in treasure, caused the United States to reevaluate the nature of its Caribbean empire. For nearly two decades the empire had been maintained by force, threatened and actual, and by war's end Americans were tiring of the expensive, open-ended commitments their government was making to occupation operations in countries like Nicaragua, Haiti, and the Dominican Republic. They were also increasingly convinced that, devastated by four years of savage warfare, European nations were unlikely to pose any significant threat to U.S. interests in the region. Both the Democratic and Republican parties read the prevailing public sentiment and quietly dropped all approving mentions of interventionist operations from their election year platforms in

securing the Panama Canal, see David McCullough, The Path Between the Seas: The Creation of the Panama Canal, 1870-1914 (New York: Simon \& Schuster, 1977).

${ }^{32}$ For more, see Thomas M. Leonard, Central America and the United States: The Search for Stability, The United States and the Americas (Athens: University of Georgia Press, 1991), 55-78.

${ }^{33}$ Richard F. Grimmett, Instances of Use of United States Armed Forces Abroad, 1798-2009, vol. RL32170 (Washington, DC: Congressional Research Service, 2010).

${ }^{34}$ For a good overview, see David Healy, Gunboat Diplomacy in the Wilson Era: The U.S. Navy in Haiti, 19151916 (Madison: University of Wisconsin Press, 1976). 
1920. ${ }^{35}$ A consensus began to form in Washington that the United States should cultivate a broad political stability in region favorable to its interests without resorting to force. That consensus strengthened throughout the decade as Latin American resentment at U.S. gunboat diplomacy mounted. That anger boiled over when the issue of U.S. interventionism came up for discussion at the Sixth International Conference of American States in Havana in 1928, where a chorus of "anti-American diatribes" from Latin American delegates convinced U.S. diplomats that they had to find a new basis for U.S. policy toward Latin America, and fast. ${ }^{36}$ Thus accelerated the turn in U.S. policy away from armed intervention in Latin America that would culminate with President Franklin D. Roosevelt's declaration of a non-interventionist "Good Neighbor Policy" in 1933.

But at the same time that U.S. policymakers were orchestrating the beginnings of a pullback from the Caribbean, initiating a fundamental transformation in the American empire, they became intent on significantly expanding the United States' commercial and strategic influence further south in Latin America - on the South American continent. Prior to the end of World War I, South America had been firmly on the outside of the U.S. empire. For years the concentration of American economic and security interests in the Caribbean and Central America had made it unnecessary for U.S. officials to contemplate extending gunboat diplomacy missions further south. ${ }^{37}$ Moreover, in terms of commercial and military

\footnotetext{
${ }^{35}$ Lars Schoultz, Beneath the United States: A History of U.S. Policy Toward Latin America (Cambridge: Harvard University Press, 1998), 252.

${ }^{36}$ Langley, America and the Americas: The United States in the Western Hemisphere, 131-32.

${ }^{37}$ This conclusion was reinforced by the hard reality that, for much of this time, the U.S. Navy's capability to project naval power around South America was severely limited. James R. Holmes notes that, in the early 20th century, "U.S. 'jurisdiction' over American affairs could go only as far as the military might of the Republic would carry it" and that noted naval theorist Alfred Thayer Mahan maintained that "U.S. power ebbed as the distance from its coastlines increased, especially when there were no forward bases to support power projection. Logistics represented a severe constraint on U.S. Navy operations south of the Caribbean Basin." See James R.
} 
influence, South America (especially its east coast and distant southern reaches) had historically been the purview of Europe. However, the unprecedented carnage that devastated Europe between 1914 and 1918 led European nations that had maintained military and naval advisory missions in South America (Germany, France, Britain) to recall their personnel for service on the western front. At the same time, European trade in the Americas fell victim both to wartime economic dislocations and to naval warfare that made the safe passage of commerce across the Atlantic all but impossible. Together, by war's end these forces produced a collapse in European strategic and economic influence in the Western Hemisphere.

Foreign policymakers in the administration of U.S. President Woodrow Wilson viewed these developments as a grand opportunity for the United States, as did American businessmen keen on exploiting South America as a source of raw materials and as an export market for finished U.S. goods. The question confronting Washington at the dawn of the 1920s was how best to integrate South America into the changing U.S. empire: for practical reasons, the empire had to be kept politically stable, but the American public was increasingly uncomfortable with using armed force to do the job. It was amid debates over these weighty issues about fundamental national interests that a request arrived from the new, ardently pro-U.S. president of Peru, Augusto B. Leguía (see Appendix 1, Photo 1), to furnish his government with a team of U.S. naval officers (known as a naval mission) to "reorganize and direct" the Peruvian Navy. As this dissertation explains, over time U.S. foreign policymakers came to view the naval mission that followed as an almost ideal type of solution to the challenges they confronted balancing the United States' aspiration to draw

Holmes, Theodore Roosevelt and World Order: Police Power in International Relations, 1 st ed. (Washington, D.C.: Potomac Books, 2006), 81-82. 
South America into its imperial fold with prevailing political realities that made armed intervention there inconceivable. Once in place, the U.S. naval mission to Peru gave Washington the ability to begin expanding its strategic and economic influence on the continent while at the same time helping to cultivate political stability without having to wield the threat of intervention.

It is in a consideration of the U.S. naval mission to Peru that this study's second organizing theme, closely related to the first, emerges: U.S. relations with Peru during the interwar period are best understood as an ongoing negotiation in which both nations, despite wide disparities in economic power, military might, and political influence, exercised significant influence over the course of the relationship. ${ }^{38}$ On its surface this might seem an odd assertion to make, given this study's use of the term "empire" to describe the framework within which the United States has pursued its interests in the Americas. But in embracing the term, this study's analysis rejects the simplistic view of empire as a vehicle for the outright domination of weaker nations by stronger ones. It accepts instead a more sophisticated view of imperial relationships in which both the stronger and weaker nations, at various turns, succeed in advancing their own interests despite the broad and persistent inequality in power between them. ${ }^{39}$ Such was certainly the case in U.S.-Peruvian relations

\footnotetext{
${ }^{38}$ In embracing this basic premise, this work is part of a movement that has coursed through the literature of U.S.-Latin American relations over the past decade that seeks to (as Max P. Friedman has put it) "bring Latin America back in." I share Friedman's concern that the dominance of revisionism in the historiography of U.S.Latin American relations from the 1960s through the 1990s painted a general portrait of those relations in which Latin American nations were acted upon by the United States, and had little to no power to influence that relationship to advance their own ends. Examples of the strength of this trend in the 1980s and 1900s include Walter LaFeber, Inevitable Revolutions: The United States in Central America, 1st ed. (New York: Norton, 1983). See also Schoultz, Beneath the United States: A History of U.S. Policy Toward Latin America. For an excellent assessment of the limitations of revisionism and the explanatory power of "bringing Latin America back in," see Max Paul Friedman, "Retiring the Puppets, Bringing Latin America Back In: Recent Scholarship on United States-Latin American Relations," Diplomatic History 27, no. 5 (2003): 621-36.

${ }^{39}$ For more on this idea, see T. J. Jackson Lears, "The Concept of Cultural Hegemony: Problems and Possibilities," The American Historical Review 90, no. 3 (1985)..
} 
during the eleven-year rule of Peruvian President Augusto Leguía (1919-1930), a period know in Peruvian history as El Oncenio.

From his first few months in office, Leguía, whose Patria Nueva ("New Fatherland") approach to national development called for developing intimate economic and political ties with the United States, demonstrated a keen ability to leverage U.S. power to advance his own objectives of growing Peru's economy, settling its borders, and strengthening his hold on power. These concerns led him almost immediately to seek a naval mission from the United States, something that Washington, eager to expand its economic and strategic influence in South America in the wake of World War I, quickly proved willing to provide. Throughout the ensuing decade that the mission served his government (1920-1930), Leguía used it to secure new naval arms from the United States, develop a national aviation system, and counterbalance the domestic influence of Peru's politically active Army. This is not to suggest that, under Leguía, Peru's relationship with the United States was that of an equal dealing with an equal. Nor is it to suggest that Leguía got everything he wanted from the relationship. Certainly he did not. Leguía would undoubtedly have preferred to receive far more than the $\$ 100$ million in foreign loans he secured from the United States between 1920 and 1930. Moreover, he surely would have liked to build a substantially larger, more powerful naval fleet than was possible given his nation's limited fiscal resources. But as this dissertation explains, at every turn Leguía proved to be a shrewd negotiator in his dealings with Washington, often pushing U.S. foreign policymakers further than they wished to go in lending him economic, naval, and political support. The things he did through that adept maneuvering to advance Patria Nueva during his Oncenio were significant, and do not 
conform to the results one might expect had Peru experienced complete domination by the United States.

The closeness of the relationship Leguía forged with the United States points to the third of this dissertation's organizing themes: that there has often been a divergence between the ideals the United States has championed in the Americas and the reality it has helped to create. Most often, scholars have pointed to the years of the "Good Neighbor Policy," World War II, and the Cold War when assessing the origins of U.S. support for dictatorship in Latin America. ${ }^{40}$ But in the immediate aftermath of World War I, as U.S. President Woodrow Wilson trumpeted the ideals of democracy and national self-determination and labored to create the League of Nations, the United States deepened its relationship with Leguía even as clear evidence emerged of his growing repressiveness and ambition to establish a longlasting dictatorship. When, very early in his rule, he began shutting down opposition newspapers, purging high-level officers from Peru's Army, and imprisoning political adversaries, the United States looked the other way and continued to give him material and political support. From Washington's perspective, the most important thing was that Leguía was demonstrating an enthusiasm for U.S. financial and military methods, and a desire to attract ever-greater amounts of American influence within Peru. In that regard he was unique among Latin American leaders of the time. Expanding economic and strategic influence in South America was the overriding priority of U.S. inter-American policy in the early 1920s, and Leguía was seen by U.S. foreign policymakers as a willing partner who could help them accomplish that goal. He was a member of Peru's mestizo aristocracy, someone, U.S. foreign policymakers believed, whose strong hand could corral Peru's majority-indigenous

\footnotetext{
${ }^{40}$ This case is made most forcefully by Bryce Wood in his follow-up to his famous work on the origins of Franklin D. Roosevelt's Good Neighbor Policy. See Bryce Wood, The Dismantling of the Good Neighbor Policy, 1st ed. (Austin: University of Texas Press, 1985).
} 
population and lead it to a prosperous future that for reasons of racial inferiority would be otherwise impossible for Peru to achieve. Of course, they knew, an autocrat could better protect American interests, as well.

Accordingly, throughout the 1920s, the United States intensified its relationship with Leguía even further. American capital flooded into Peru, and U.S. companies secured valuable concessions from Leguía himself to exploit the country’s abundant natural resources. Meanwhile the U.S. naval mission, whose members became integral members of Leguía's inner circle and constituted a vital element of broader U.S. policy in Peru, cultivated as close an association with the Peruvian Navy as the United States enjoyed with any naval establishment in the hemisphere. By the late 1920s, such inroads caused American foreign policymakers to see the entirety of the U.S. relationship with Leguía as a resounding success. However, they also obscured the harsh realities that confronted Peruvians who opposed Leguía's rule, and gave U.S. policymakers a false sense of security that Leguía's popularity among his countrymen was following the same upward trajectory as Peru's impressive economic growth. Throughout the decade, U.S. policy became personally tied to Leguía helping strengthen his rule into the entrenched dictatorship he sought - and as time went on, this association made it increasingly difficult for American foreign policymakers to see (let alone comprehend) the deep fissures that Leguía's repressive rule was opening beneath the veneer of prosperity his economic policies had created. Thus did the United States openly back a Latin American dictator, and clearly expose itself for the first time in South America as a nation whose professed ideals and behavior were often two very different things. 
Finally, this study adopts a broad view of naval power and demonstrates the importance of non-coercive naval activity to relations between nations. ${ }^{41}$ That is, it emphasizes the diplomatic significance of naval activities beyond combat operations and gunboat diplomacy, which together have tended to dominate treatments of naval affairs in the literatures of both foreign relations and naval history. ${ }^{42}$ Throughout the $1920 \mathrm{~s}, 1930$ s, and into the 1940s, the U.S. Navy's roles advising the Peruvian Navy and conducting highly public goodwill cruises to Peruvian shores constituted a large share of the overall diplomatic give-and-take between the United States and Peru. During the Leguía years, the American naval mission to Peru was a primary vehicle through which U.S.-Peruvian relations were conducted. Mission members were integral parts of Leguía's inner circle, holding positions of high rank and authority in the Peruvian Navy. Mission personnel, especially their chief (who occupied the highest uniformed position in the Peruvian Navy), often enjoyed more direct access to the president than the U.S. Ambassador in the country. Not only did this facilitate ever-closer relations between the United States and Peru during the 1920s, it laid the groundwork for an extraordinarily close institutional association between the U.S. and

\footnotetext{
${ }^{41}$ This work proceeds from naval theorist Ken Booth's premise that, wherever a nation's navy ventures in the world, its vessels are "small mobile pieces of national sovereignty" and carry with them the full weight of a nation's intentions and commitments - whether they are carrying out coercive gunboat diplomacy, or actions aimed at fostering goodwill and enhancing the nation's international prestige. See Booth, Navies and Foreign Policy, 41-45.

${ }^{42}$ Naval history's tendency to confine treatments of naval power's foreign relations relevance to coercive naval diplomacy has roots in the work of famed naval theorist Alfred Thayer Mahan, who in his seminal The Influence of Sea Power Upon History argued that "Whatever may be the determining factors in strifes between neighboring continental States, when a question arises of control over distant regions, politically weak, whether they be crumbling empires, anarchical republics, colonies, isolated military posts, or islands below a certain size, - it must ultimately be decided by naval power, by the organized military force afloat, which represents the communications that form so prominent a feature in all strategy." See A. T. Mahan, The Influence of Sea Power Upon History, 1660-1783 (New York: Dover Publications, 1987), 416. As Brian Loveman notes, "Mahan saw potential threats to America almost everywhere and warned that action must be taken to deter or destroy them," and that Mahan "sought to instill fear of potential enemies and their capabilities, or even their potential capabilities, into public and congressional debates on naval budgets and doctrine." See Brian Loveman, No Higher Law: American Foreign Policy and the Western Hemisphere Since 1776 (Chapel Hill: University of North Carolina Press, 2010), 151-52.
} 
Peruvian navies that would endure for decades even as winds of politics blew in wildly different directions.

That mutual fondness between the two nations' navies proved vital, for example, to U.S.-Peruvian cooperation in hemispheric security affairs as the clouds of war gathered in Europe and the Pacific in the late 1930s. The Peruvian Navy lobbied heavily from 1935 through 1937 for the establishment of a new U.S. naval mission to replace the one that had been withdrawn after Leguía's 1930 overthrow. Sent to Lima by the Franklin D. Roosevelt administration in 1938, that mission paved the way for more intimate links not only with the Peru's Navy, but with its aviation establishment, Army, and political leadership after the years of drift that had followed Leguía's downfall. In total, these naval activities helped fashion a security partnership between the United States and Peru that enhanced Washington's efforts to build inter-American unity and defend the Western Hemisphere from external threats. Before and during World War II, elements of the U.S. Fleet made goodwill visits to the Peruvian port of Callao that gave public expression to this emerging security partnership. Meanwhile, in Washington, the U.S.-Peruvian naval relationship (and U.S. naval activities in Latin America more generally) was a regular topic of discussion among high-level officials in the Roosevelt administration who were charged with hemispheric security efforts.

This is not to suggest, however, that naval cooperation always made for smoother relations between Washington and Lima. Indeed, especially during Leguía's Oncenio, it often complicated the relationship. The fact that mission personnel served as officers in the Peruvian Navy while retaining their rank and status in the U.S. Navy, for example, raised difficult questions about what status they should assume in the event that Leguía's 
government went to war with another nation or moved to forcibly quell a domestic disturbance. It also blurred lines of authority and opened the way for some officers, most notably aviation chief Harold B. Grow (Commander, U.S. Navy), to develop close, personal friendships with Leguía that made it all but impossible for the naval mission to remain neutral in national affairs beyond the Navy. This was true in large part because the Peruvian president made it a priority to keep the naval mission - and by extension, the Navy politically close. It was true also because Leguía saw the Navy as the ultimate guarantor of Peru's security and territorial integrity, and made its expansion a priority of his administration. Throughout the decade he effectively used the naval mission to advance that goal - giving naval mission chiefs prominent roles in advocating for naval expansion, using naval mission contacts to facilitate arms purchases in the United States, and, during the 1930 revolution that overthrew him, calling on naval mission members to take an active role in preserving his regime. In each of these instances and in others, close naval cooperation made American diplomats' jobs more difficult. But just as the numerous successes did, these complications demonstrated the centrality of naval power to the U.S.-Peruvian relationship.

\section{AN OVERVIEW OF PERUVIAN GEOGRAPHY}

To appreciate why naval power was so central to the U.S.-Peruvian relationship between the World Wars, it is important to understand the dominant features of Peru's geography (see Appendix 2, Map 2) as well as the basic contours of its national history since independence from Spain. Situated mid-way down the west coast of South America, Peru possesses a coastline of nearly fifteen-hundred miles in length that stretches from Ecuadorian frontier in the north to the Chilean border in the south. Hugging the coast is Peru's arid costa (coastal) region, a narrow stretch of land that ranges, on average, between twenty and ninety 
miles in width between the Pacific Ocean and the heights of the Andean mountains which run the length of the country and form its dominant geographical feature. Home to Peru's capital city, Lima, as well as most of Peru's mestizo population (persons of mixed indigenous and European descent), the costa has long been the country's economic and political power center. It is a predominantly a desert land whose main contribution to the nation's economic life in the nineteenth and early twentieth centuries was as a provider of exportable raw materials, the most prominent ones being guano (the calcified droppings of coastal birds, used as an agricultural fertilizer) and nitrates (substances such as saltpeter, components both of fertilizers and explosives). ${ }^{43}$

Acting almost as a wall, Peru's sierra (mountainous) region runs the length of the country, separating the western costa from the country's vast eastern selva (rainforest) region. Rising to a maximum height of more than twenty-two thousand feet, the Andes mountains constitute a formidable geographical obstacle within Peru, and throughout its national history, their persistent presence has significantly complicated the task of achieving the economic, social, and cultural cohesion so necessary to modern nationhood. Seat of the pre-colonial Inca Empire, the sierra has remained home to the largest concentration of Peru's large, vibrant indigenous population since independence. ${ }^{44}$ Throughout its national history, Peru has had difficulty forging socioeconomic linkages across this harsh topography. As a result, the sierra is economically and socially distinct within Peru, as is the even more isolated eastern selva that it separates from the costa. Comprising nearly sixty-percent of

\footnotetext{
${ }^{43}$ See Daniel M. Masterson, The History of Peru, The Greenwood Histories of the Modern Nations (Westport: Greenwood Press, 2009), 1-5.

${ }^{44}$ For more on pre-Colombian Peru and the colonial period, see Peter F. Klarén, Peru: Society and Nationhood in the Andes, Latin American Histories (New York: Oxford University Press, 2000). See also John C. Chasteen, Born in Blood and Fire: A Concise History of Latin America, 1st ed. (New York: Norton, 2001).
} 
Peru's total geographical area, Peru's rainforest region is home to less than ten-percent of the country's total population. It is a region rich in natural resources that Peruvians and foreigners alike have long viewed, often misguidedly, as the economic future of the whole country. ${ }^{45}$ Accentuating the selva's appeal has been the fact that rivers originating there combine to form the headwaters of the mighty Amazon River, South America's largest navigable waterway, which gives Peru direct shipping access to the Atlantic Ocean and solidifies its claim to be a transcontinental nation. ${ }^{46}$ Still, largely cut off from the nation's economic and political center in the costa, Peru's selva remains tremendously isolated.

Peru's geographic reality, then, is that of a nation of three largely distinct socioeconomic regions. Over time, Peru's challenging geography has made overland trade with neighboring countries very difficult. At the same time, though, it has made ground invasions of Peru difficult propositions for potential enemies, and has done much to enhance Peru's territorial security. In the nineteenth and early twentieth centuries, the periods vital to any understanding of Peru's security orientation during the interwar period, these two realities came together to accentuate the importance of the Pacific coastline to Peru's national identity. On the one hand, the coast came to serve as Peru's most important economic and political linkage to the international community. Its foreign trade and communications with other nations of the world were almost wholly dependent on ocean-going modes of transportation. On the other hand, though, this dependence helped make the Pacific coastline Peru's greatest strategic vulnerability. The latter would be demonstrated with devastating

\footnotetext{
${ }^{45}$ In the late nineteenth century, the selva gave birth to a boom in rubber production, which proved to be shortlived when British interests began producing larger quantities more cheaply in southeast Asia in the early twentieth century. Beginning in the 1960s, Peruvian and foreign investors again looked to the selva as savior of the nation's economy oil reserves were discovered there. By the early 1970s, though, scientific study revealed those reserves to be smaller than initially thought - large enough, only, to provide Peru with enough crude oil to attain self-sufficiency. The costs of extracting that oil and transporting it to market were far too high.

${ }^{46}$ Masterson, The History of Peru, 5-10.
} 
clarity in the later 19th century, when Peru and Chile went to war to settle a mineral rights dispute centered in the coastal desert that spanned the frontier they shared with Bolivia.

\section{THE WAR OF THE PACIFIC AND ITS AFTERMATH}

The War of the Pacific fought against Chile between 1879 and 1883 was the defining experience of Peru's first century of independence, and did much to shape its economy, foreign policy, and strategic posture well into the twentieth century. The war's origins lie in both the economic and strategic realms. Economically, it has roots in Peru's development as a nation whose prosperity by the 1870 s was tied up in a single commodity: guano. Over the course of many centuries, the rich marine life in Peru's coastal waters and the extremely dry climate that prevailed in Peru's costa region combined to preserve massive buildups of coastal bird droppings rich in nitrogen and phosphorous on small islands located just off Peru's central coast. The discovery of these deposits in the 1830s, some of the largest and richest in the world, sparked a vibrant international trade as Peru fed surging demand for fertilizer in the United States and in Europe. Although Peru granted concessions to foreign companies to exploit the deposits, it retained for itself a majority claim to the overall revenue of overseas guano sales - a development that kept the Peruvian government's coffers relatively full as the trade boomed from the early 1840s into the 1870s. Unfortunately for Peru's national development, wealth from the guano trade remained concentrated in the hands of a small group of elite merchants centered in Lima, and did not result in a balanced economic growth whose benefits were spread throughout the whole nation. This lack of balance ensured that Peru would be in for economically difficult times when, as was bound to happen, disruptions in supply and demand combined to slow the trade's frenzied pace. By the early 1870s, exporters had all but exhausted Peru's valuable guano deposits. At that 
same moment, a global economic depression struck that sapped international demand.

Wholly dependent on the guano trade and without other sectors capable of carrying Peru's economy forward, the country sank into crisis. $^{47}$

By the early 1870s, however, Peruvian and foreign investors had begun to discover large, valuable deposits of nitrates (a valuable component in the manufacture of fertilizer, as well as explosives) in the Atacama Desert that spanned the coastal regions of southern Peru, Bolivia, and northern Chile. At the time, national borders were imprecise in the Atacama due to the persistence of long-unsettled claims dating back to the days of Spanish colonialism. The discovery of nitrates ignited an investment frenzy that quickly exposed the ad hoc nature of the three nations' boundaries. In the span of a few short years foreign capital flooded into the region, and the three nations, sensing that the desert's potential riches held the keys to their economic recoveries, immediately staked overlapping mineral rights claims. In defense of Peru's interests Manuel Pardo, founder of Peru's first civilian political party (the Civilistas) and the nation's first civilian president, nationalized the nitrate industry operating in the Peruvian Atacama (the region of Tarapacá) in 1875. Among the nationalized entities were several Chilean and European companies that had been operating under contracts previously approved by the Peruvian government. The Chilean government saw Pardo's move as an affront to its national interests, and the level of bitterness and rancor among the three neighbors grew. Shortly thereafter, Bolivia, the poorest of the three, sought to solidify its claims by enacting a small tax (ten centavos per ton) on nitrates extracted by foreign firms from its portion of the Atacama. Again the Chilean government took exception, seeing the tax as a violation of existing agreements that Chilean firms had made with the Bolivian

\footnotetext{
${ }^{47}$ This summary is based on Fredrick B. Pike, The Modern History of Peru, Praeger Histories of Latin America (New York: Praeger, 1967), 120-50. See also Masterson, The History of Peru, 81-82.
} 
government. With its government's backing, the Chilean Antofagasta Mining Company refused to pay the Bolivian tax, a move that resulted in Bolivian forces forcibly seizing the company. To Chile, both Bolivia's moves and Peru's nationalizations were unjustified provocations. By early 1879, the Chilean government resolved to apply force to end the injustices. In February, Chilean ground and naval forces moved to seize the city of Antofagasta. Bolivia responded with a declaration of war, and in April, Chile responded by declaring war on both Bolivia and Peru. The War of the Pacific was on.

As important as economic issues were to the coming of the war, though, one cannot understand the countries' embrace of military solutions without also understanding the strategic reality of South America's west coast in the years before 1879. Since achieving their independence from Spain, Peru and Chile had each attempted, at various turns, to assert dominance on their shared coast and exercise preponderant influence over the waters of the southeastern Pacific. Throughout the early years of their existences as independent nations, wracked as they both were with internal political and economic problems, neither nation was entirely successful in the pursuit. The tensions that emerged over nitrate exploration in the shared frontier in the early 1870 s raised the stakes of this long-term rivalry considerably, and sparked efforts in both countries to enhance their security. Chile was the strongest of the three in military and naval terms, boasting a naval fleet with faster, more modern, more heavily armed ships than the Peruvian Navy possessed, and an army that was better organized, better equipped, and better versed in modern techniques of discipline, combat leadership, and logistics. Struggling under the weight of a bad economy and heavy indebtedness brought on by years of heavy borrowing compounded by the global economic depression, in the years before the war the Peruvian government was not in a position to 
build its naval and ground forces to quantitative or qualitative parity with the superior Chileans. Instead, consistent with Pardo's preference to seek security through treaties with neighbors rather than through expensive military buildups, Peru opted to ally itself with neighboring Bolivia in the hope that, should war come, together their military establishments could hold the superior Chileans at bay. In 1873 Peru signed a secret defensive alliance with Bolivia, the terms of which required each nation to come to the other's defense in the event of Chilean aggression. It was Peru's delivery on this promise in the wake of Chilean operations against Antofagasta that prompted the Chilean government to include Peru in its April, 1879 declaration of war against Bolivia. ${ }^{48}$

The War of the Pacific demonstrates as clearly as anything in Peru's national history the importance of coastal security and naval forces to its overall national security, for despite the fact that combat operations continued all the way into 1883, the war was, for all intents and purposes, won by Chile at sea in late 1879 - less than one year into hostilities. That is because the mountainous, desert terrain and vast expanse of the Atacama Desert made ground invasions from one country's territory into the other all but impossible to undertake. The only way Peruvian or Chilean armies could fully secure the other's nitrate-rich deserts or capital city was if their navies could land them safely on enemy shores within reasonable marching distance of the objective. Thus command of the sea was essential to victory. Accordingly, in the war's first year, both Peru and Chile put the overwhelming share of their war efforts into achieving supremacy on the water. In April, 1879 the quantitatively and qualitatively superior Chilean Navy initiated a passive strategy aimed at blockading Peruvian

\footnotetext{
${ }^{48}$ The best recent scholarly treatment of the War of the Pacific is William Sater's 2007 work, Andean Tragedy: Fighting the War of the Pacific. My brief discussion of the economic and strategic causes of the war is based in large part on Sater's work. See William F. Sater, Andean Tragedy: Fighting the War of the Pacific, 1879-1884, Studies in War, Society, and the Military (Lincoln: University of Nebraska Press, 2007), 1-115. See also Masterson, The History of Peru, 82-83.
} 
ports, choking off Peru's commerce, and denying the Peruvian government a vital source of revenue with which to sustain its war effort. The problem with this strategy was that it gave Peru's enterprising fleet commander, Capitán de Navio (later Almirante) Miguel Grau Seminario, complete freedom of action. The Peruvian used that freedom to maximum effect. Throughout much of the war's first year, Grau was unmolested by the static Chilean Navy as he shuttled Peruvian troops from Lima to the southern front and harassed Chilean ports and merchant vessels.

For months Chilean naval strategy failed to adapt to Grau's activism, ceding the initiative at sea to the smaller Peruvian fleet. Only when Grau's best armored frigate, the Independencia, ran aground in pursuit of a Chilean ship off the southern Peruvian port of Iquique did Chilean fortunes begin to turn. By historian William Sater's estimation, the loss reduced the small Peruvian fleet's operational capability by almost forty-percent, accentuating Chile's naval superiority. Although Grau remained an active and elusive enemy, the war turned decisively and permanently against Peru in early October. That is when a new Chilean naval commander divided his fleet and trapped Grau's Huáscar, the crown jewel of the Peruvian fleet, off Punta Angamos, just north of Antofagasta. Chased by faster, more heavily armed ships, the Huáscar struggled to return fire. One of the Chilean volleys struck the ship's armored bridge, killing Grau instantly and depriving the Peruvian Navy of the strategist and tactician who had kept its war effort alive against significant odds. In a matter of hours, despite numerous gallant but futile attempts to outrun its Chilean pursuers, the Huáscar succumbed. Chile had completed its destruction of Peruvian naval power, and had won command of the seas. Peruvian shores were wide open to invasion. Within a month, the Chilean Army occupied the Peruvian province of Tarapacá. Six months 
after that, the Chilean Navy put ground forces ashore further north in Peruvian territory at Arica, depriving Peru of its last source of vital nitrate revenue with which to fund its war effort. With complete freedom to act at sea, in late 1880 Chile succeeded in putting more than ten thousand ground troops ashore near Lima. Within two weeks, despite heavy resistance from Peruvian soldiers fighting to defend their capital, the old city founded centuries earlier by Spanish conquistador Francisco Pizarro fell into Chilean hands. The war would continue into 1883 as Peruvian forces took to the mountains of the sierra to mount a guerilla resistance. But those actions, as effective as they sometimes were in a tactical sense, ultimately proved to be strategically fruitless. In losing the naval war, Peru had completely lost the ability to defend its territory. With it, Peru had lost the wider war. ${ }^{49}$

Chile's victory in the War of the Pacific was a total one, and in many ways serves as confirmation of the old adage "to the victor belong the spoils." The Treaty of Ancón concluded on October 20, 1883 confirmed nearly all of Chile's wartime gains. It forced Peru to permanently cede its nitrate-rich Tarapacá region, and validated Chile's absorption of Bolivia's Pacific coast - turning the nation named for Simon Bolivar, the liberator of South America, into the continent's second landlocked nation (Paraguay was the first). The Treaty failed, however, to settle all of the belligerents' concerns. It delayed action on the fates of the coastal Peruvian provinces of Tacna and Arica, at the north end of the Atacama Desert, and instead left them up to settlement by a plebiscite to be held within ten years. When held, the vote was supposed to determine whether the provinces should be ceded to Chile or returned to Peruvian control. In the meantime, over Peruvian objections victorious Chilean

\footnotetext{
49 This narrative of the war's key developments is based on Sater, Andean Tragedy: Fighting the War of the Pacific, 1879-1884, 116-69. For a superb, concise analysis of the strategic significance of the Battle of Iquique, see Sater's 2007 article length treatment: Sater, "Revisiting the Battle of Iquique," History Compass 5, no. 1 (2007): 218-26.
} 
forces were allowed to occupy both provinces. As Chapter 2 will discuss, this awkward arrangement (de jure neutrality, supervised by de facto Chilean control) virtually ensured that no plebiscite would be held within the timeframe specified by the Treaty of Ancón. It all but guaranteed that the issue would continue to roil Peruvian-Chilean relations well into the twentieth century.

Peru's defeat in the War of the Pacific shaped the basic contours of its foreign and defense policies from the late nineteenth century into the twentieth. The loss of its southernmost province was a bitter pill that, for decades, steeled Peruvian resolve to hold on to Tacna and Arica. As a result, a succession of Peruvian governments between 1883 and 1919 made breaking the impasse over Tacna and Arica a priority. ${ }^{50}$ Peruvian insistence on retaining both provinces ran headlong into patient indifference from Chile, whose forces already occupied both. The result was a long-term diplomatic stalemate that Peruvians considered an affront to their national honor. At the same time, Peruvians began to take stock of the military and naval lessons of their defeat. Although military concerns were largely overshadowed by considerable turbulence in Peruvian politics in the late 1880s and early 1890s, Peru's leaders began to express grave concerns over Chile's postwar efforts to modernize and expand its Army and Navy. Particularly alarming to Peru was the fact that Chile had begun employing German military and naval advisers in 1885 . Painfully aware that military and naval inferiority had been at the heart of their recent defeat, and convinced that their nation could benefit from outside assistance, Peruvians also turned to foreign advisers. Because a ground war seemed likely if diplomacy failed to break the stalemate on Tacna and Arica, Peru turned first to augmenting its Army, welcoming a mission of advisers

\footnotetext{
${ }^{50}$ Ronald Bruce St. John, The Foreign Policy of Peru (Boulder: L. Rienner Publishers, 1992), 124-27.
} 
from the French Army in 1895. The move inaugurated a close institutional relationship that would last with few interruptions until World War II. Not until Augusto Leguía came to power in July of 1919, however, did a Peruvian president view the long-running Tacna-Arica controversy and the nation's military-strategic challenges as parts of an integrated whole. Armed with a keen awareness of the War of the Pacific's clearest strategic lesson, Leguía set out to make Peru's Navy equal to the task of serving as the ultimate guarantor of Peruvian security.

\section{STRUCTURE OF THIS STUDY}

This dissertation proceeds in a roughly chronological fashion. Chapter 1 assesses the unique conditions that gave rise to the U.S. naval mission sent to Peru in 1920, and how a convergence of interests between the United States and Peru shaped the mission and its work. Specifically, it discusses growing U.S. economic and strategic interests in South America after the First World War, and analyzes the ways in which the ardently pro-American Leguía believed securing a U.S. naval mission would advance his particular interests for Peru's security and economic development. Chapter 2 describes the work that the U.S. naval mission did to overhaul and reform the Peruvian Navy from the time of its arrival in 1920 until the Leguía's overthrow in 1930 - a ten-year period in which, per Leguía's insistence, U.S. personnel exercised full command over the Peruvian naval establishment. This treatment focuses specifically on the U.S. naval mission's efforts to reform Peru's system naval education, establish a submarine force as the foundation of Peru's naval defenses, and create a national aviation system capable of furthering Peru's security and economic interests. Chapter 3 explores the specific ways in which the naval mission's role in formal command of Peru's Navy often complicated relations between the two nations while Leguía 
was in power. It then addresses the challenges the mission's status posed after Leguía was overthrown in August of 1930, and traces how the violent unrest of Peruvian politics in the wake of Leguía's fall ultimately forced U.S. authorities to withdraw the mission entirely in early 1933. Chapter 4 explores Washington's search for new ways to exercise influence in Peru and throughout Latin America consistent with its renunciation of armed interventionism. Analyzing high-profile visits of U.S. Navy units to Peruvian waters, it traces the origins of the policy of employing goodwill cruises by U.S. naval ships to help promote good neighborism during the Herbert Hoover and Franklin D. Roosevelt administrations. And finally, Chapter 5 assesses how the United States utilized both of the types of naval diplomacy it had fashioned during the interwar period - naval missions and goodwill cruising - to help ensure Peruvian cooperation in U.S. hemispheric defense plans, as well as to forge a broad inter-American unity in the late 1930s and during World War II. 


\section{CHAPTER 1: A CONVERGENCE OF INTERESTS, 1919-1921}

The U.S. naval advisory mission that arrived in Lima, Peru in September of 1920 was the product of a convergence of interests between the United States and the government of new Peruvian President Augusto B. Leguía. ${ }^{51}$ For the administration of U.S. President Woodrow Wilson, the mission was a clear and visible expression of a new postwar commitment to expand U.S. strategic and commercial influence in South America, filling the vacuum that had been left by European nations' wartime retreat from economic and military activities on that continent. Amid its efforts to cultivate a new order to ensure global peace, the United States set about extending its Latin American sphere of influence beyond the Caribbean to include the entirety of South America. Situated on the west coast of South America, mid-way between the Caribbean basin, where U.S. influence was traditionally strongest, and the southern reaches of South America, where European influence historically eclipsed that of the United States, Peru was an essential focus of Washington's influencebuilding effort.

For Leguía, who had come into office in mid-1919, developing a close economic and security association with the United States was an overriding priority from day one. The greater the U.S. involvement in Peru's economic and security affairs, he believed, the better. Thus, throughout his eleven-year rule he proved to be a willing partner in U.S. designs. It is important to note, however, that while enthusiastically cooperative, Leguía was no mere vassal of Washington. Over the course of his eleven-year rule (known to Peruvian history as

\footnotetext{
${ }^{51}$ For the purposes of communicating the function that the U.S. naval officers sent to Peru in 1920 were to fulfill, here in the introduction I use the term "naval advisory mission." As this chapter will discuss, however, the work that the U.S. officers undertook in Peru was far more than "advisory." They assumed actual positions of command authority over the Peruvian Navy, and throughout their tenure, they were collectively known as a "naval mission."
} 
El Oncenio) he pursued an unprecedented level of economic and security cooperation with the nation he often referred to as "the great republic of the north," and did so for his own reasons. The U.S. capital and expertise he attracted to Peru was calculated to advance his own distinct vision of a stable, secure, and prosperous future for Peru. To realize that goal, Leguía believed, he had to deepen Peru's trade and financial ties to the United States, resolve his nation's several border disputes with neighbors, and consolidate his hold on power. As this chapter will discuss, he saw naval advisers from the United States as essential to achieving each of these three objectives.

\section{LOOKING SOUTH: U.S. INTERESTS AFTER THE FIRST WORLD WAR}

The United States emerged from the First World War as the strongest of the victorious Allies in economic and military terms, determined to establish a new, peaceful global political order and an open capitalist economic world defined by equal access to raw materials and export markets, and equal opportunities for trade and investment. ${ }^{52}$ Officials in the Woodrow Wilson administration believed that, more than at any time in the nation's history, wartime dislocations in international commerce had demonstrated the importance of a robust and growing foreign trade to the basic health of the U.S. economy. As historian Michael Krenn notes, the disruption of U.S. trade at the outset of World War I had briefly "paralyzed" business in the United States and "brought home the necessity of overseas commerce with 'compelling force'.,53 The solution, they increasingly believed, was to use

\footnotetext{
${ }^{52}$ For more on President Woodrow Wilson's post-World War I commitment to establishing a global order to ensure international peace, see Thomas J. Knock, To End All Wars: Woodrow Wilson and the Quest for a New World Order (New York: Oxford University Press, 1992). See also John Milton Cooper, Woodrow Wilson: A Biography, 1st ed. (New York: Alfred A. Knopf, 2009), 454-534.

${ }^{53}$ Michael L. Krenn, U.S. Policy Toward Economic Nationalism in Latin America, 1917-1929, America in the Modern World (Wilmington: SR Books, 1990), 2.
} 
the power of the U.S. government to promote trade expansion overseas. ${ }^{54}$ Accordingly, U.S. officials began to embrace the idea that the nation's military and naval power could be proper tools for helping to advance American economic interests and expand U.S. strategic influence. European nations had long sent military and naval advisory missions to South America on the belief that helping to improve other countries' military and naval establishments made for smoother, more productive diplomatic relations and facilitated expanded trade. ${ }^{55}$ Keen on dramatically expanding U.S. trade in the aftermath of World War I, especially in Latin America, officials in Wilson's State Department began to see naval and military missions as useful accompaniments to U.S. economic policy. ${ }^{56}$

Latin America as a whole, and South America specifically, occupied a central place within Wilson's open world economic vision. To a greater degree than other areas of the globe, U.S. foreign policymakers agreed, greater trade with South America could help the nation address two pressing postwar needs: first, the continent could grow into a valuable export market for American manufactured goods, and more importantly, it could supply U.S. industry with a nearly endless supply of vital raw materials. ${ }^{57}$ Both would be essential if, as the Wilson administration hoped, the United States was to moderate the dramatic swings that

\footnotetext{
${ }^{54}$ Emily Rosenberg argues that, like their predecessors, Woodrow Wilson and his advisers "continued to view strategic and economic concerns as inseparable." In 1915 Wilson's Secretary of State, Robert Lansing, wrote that "commercial expansion and success are closely interwoven with political domination over the territory which is being exploited" and suggested that the extension of U.S. economic influence over Latin America was "the best way to strengthen America's strategic posture." See Emily S. Rosenberg, Spreading the American Dream: American Economic and Cultural Expansion, 1890-1945, 1st ed., American Century Series (New York: Hill and Wang, 1982), 63-64.

${ }^{55}$ Scheina, Latin America: A Naval History, 1810-1987, 127-28.

${ }^{56}$ Tulchin, The Aftermath of War: World War I and U.S. Policy Toward Latin America, 35.

${ }^{57}$ Krenn, U.S. Policy Toward Economic Nationalism in Latin America, 1917-1929, 9-13. See also Tulchin, The Aftermath of War: World War I and U.S. Policy Toward Latin America.
} 
had characterized its cyclical boom-bust economic performance over the past half-century. ${ }^{58}$ As a coastal nation with a varied geography and a wide variety of accessible, exportable natural resources, the Andean nation of Peru was integral to Washington's plans. Peru appeared especially attractive to U.S. foreign policymakers because its largest pre-war trading partner, Great Britain, had proven unable to maintain its substantial trade presence there amid the economic and demographic devastation of World War I. Britain's overall share of Latin America's foreign trade, for example, had fallen from 29-percent to 20-percent during the war. By 1920 British purchases of Peruvian exports were off 10-percent from 1900 highs, while Peruvian imports of British manufactured goods fell 32-percent during the same period. The United States had had considerable success filling the void in Peru's wartime trade, as U.S. purchases of Peruvian exports increased by 13-percent between 1914 and 1919 while Peruvian purchases of U.S. manufactured goods during the war more than doubled. By war's end, the United States supplied more than 60-percent of Peru's imports, and even though these wartime heights would ultimately prove unsustainable, they signaled an important trend: by the end of World War I, the United States had supplanted Britain as the dominant force in Peru's international trade relations. ${ }^{59}$

At the same time, Peru was becoming a strategic concern for U.S. military leaders, who looked toward South America after World War I with a mix of optimism and concern. They shared in the State Department's hope that, with Europe in disarray and U.S. power ascendant, the United States could expand its strategic influence in the hemisphere far

\footnotetext{
${ }^{58}$ This pattern of late $19^{\text {th }}$ and early $20^{\text {th }}$ century U.S. economic performance is well characterized in Walter LaFeber, The New Empire: An Interpretation of American Expansion, 1860-1898 (Ithaca: Cornell University Press, 1963).

${ }^{59}$ Statistics taken from Paul W. Drake, The Money Doctor in the Andes: The Kemmerer Missions, 1923-1933 (Durham: Duke University Press, 1989), 213-14. See also St. John, The Foreign Policy of Peru, 157.
} 
beyond its traditional bounds in Central America and the Caribbean. ${ }^{60}$ They were also concerned that European military and naval influence in South America, which had been considerable before the war, might regenerate and become a menace to U.S. interests on the continent in the postwar years. France, Germany, and Great Britain had all maintained military or naval missions in South America in the decades before the war. ${ }^{61}$ The fact that none of these three nations (which were in the midst of postwar reconstruction efforts) possessed the capability to resume their military and naval advising missions in South America immediately following the war, however, did not assuage U.S. military leaders' fears that they might once again send missions in an attempt to reopen the hemisphere to European commercial dominance. In this regard, Britain was the object of greatest concern. U.S. military leaders viewed British activities in South America with "marked uneasiness," historian Joseph Tulchin has argued, and were especially concerned about potential sales of British military and naval equipment to South American nations and the possible construction of new British coaling stations on Latin American shores. It was these fears, coupled with broader concerns that U.S. Navy leaders had about their institution's place in postwar American life, that ultimately caused them to embrace the idea of sending naval missions overseas. Such missions, Navy Secretary Josephus Daniels acknowledged, would help the United States "cultivate close diplomatic and commercial relations with South

\footnotetext{
${ }^{60}$ Early in the 20th century, the United States had asserted its claim to strategic dominance in the Caribbean. In late 1904, U.S. President Theodore Roosevelt declared his "Corollary" to the Monroe Doctrine, which held that "in the western hemisphere the adherence of the United States to the Monroe Doctrine may force the United States, however reluctantly, in flagrant cases of such wrongdoing or impotence, to the exercise of an international police power." A year later, Roosevelt reinforced this policy by declaring that "We must make it evident that we do not intend to permit the Monroe Doctrine to be used by any nation on this Continent as a shield to protect it from the consequences of its own misdeeds against foreign nations." The Roosevelt Corollary and subsequent clarifying statements became the basis of the U.S. policy of intervention in the internal affairs of Central American and Caribbean nations until the "Good Neighbor Policy" of President Franklin D. Roosevelt formally renounced such intervention. See Healy, Drive to Hegemony: The United States in the Caribbean, 1898-1917, 108.

${ }^{61}$ Scheina, Latin America: A Naval History, 1810-1987, 129-30.
} 
American countries" and would help improve the general "international situation"

throughout Latin America. Moreover, naval missions would give the Navy an important role in the nation's peacetime diplomacy. ${ }^{62}$

For economic, diplomatic, and security reasons, then, the Wilson administration was primed to respond favorably when word reached Washington in October 1919 that Leguía would formally request a U.S. naval mission for Peru. Such a mission promised to give the United States a great deal of influence in a Latin American country outside of the Caribbean, the area where U.S. influence in the hemisphere had traditionally been strongest. ${ }^{63}$ Leguía's ardently pro-U.S. orientation and Peru's geographic location made it an attractive destination. Sending a mission to Peru would help establish a different kind of military involvement in Latin America than U.S. authorities had, by then, grown accustomed to exercising. Between 1900 and 1919, Washington had dispatched military forces to Latin American nations (none south of the Caribbean) to protect U.S. interests and enforce order on twenty-six different occasions. ${ }^{64}$ While many of those interventions had been brief, several, including those in Nicaragua (1912), Haiti (1915), and the Dominican Republic (1916), had gone on for years and required sustained, costly commitments of American military assets. ${ }^{65}$ In the wake of

\footnotetext{
${ }^{62}$ Tulchin, The Aftermath of War: World War I and U.S. Policy Toward Latin America, 34-35.

${ }^{63}$ The idea to examine Latin America as a set of zones of U.S. influence occurred to me while reading Bradley L. Coleman's Colombia and the United States: The Making of an Inter-American Alliance, 1939-1960, in which the author justifies his focus on Colombia in part by recognizing that "Colombia lay in a zone of transition between the areas of greatest U.S. influence in the Caribbean and Central America and the more distant neighbors of South America's southern cone. Rooted in the geography of the inter-American neighborhood, a mixture of independence and interdependence characterized U.S.-Colombian relations during World War II and the cold war." See Bradley Lynn Coleman, Colombia and the United States: The Making of an Inter-American Alliance, 1939-1960, New Studies in U.S. Foreign Relations (Kent, OH: Kent State University Press, 2008), xvi.

${ }^{64}$ Grimmett, Instances of Use of United States Armed Forces Abroad, 1798-2009, RL32170, 7-10.

${ }^{65}$ U.S. forces occupied Nicaragua from 1912 to 1933, Haiti from 1915 to 1934, and the Dominican Republic from 1916 to 1924. At the moment Washington first contemplated sending a U.S. naval mission to Peru (1919), all three occupations were still in full force. For more on U.S. interventions and long-term occupations in Central America and the Caribbean, see Lester D. Langley, The Banana Wars: United States Intervention in the
} 
World War I, when Americans had interceded for the first time in a European ground war,

U.S. foreign policymakers accurately sensed that American public opinion was tiring of interventionism and would not support it indefinitely as an instrument of the nation's diplomacy. ${ }^{66}$ Although the United States would not formally renounce interventionism in the Americas until the early 1930s, declining public support for such operations in the Caribbean made it impossible for U.S. foreign policymakers to consider using military intervention to advance Washington's post-World War I objectives further south in the hemisphere. By and large, the State Department was not as deeply concerned about a resurgent European military presence in Latin America as Navy leaders were, and believed that, going forward, it would be unnecessary for the United States to seek formal imperial control over South American nations in order to protect its strategic and commercial interests on that continent. ${ }^{67}$ To the diplomats, a mission of U.S. naval officers serving in a friendly capacity at the invitation of the Peruvian government represented a clear departure from traditional interventionism: it would give the United States a beachhead for growing its strategic and commercial influence in South America, but would not represent a coercive use of force. Thus, they believed, Washington would not be opening itself up to the familiar charges of "Yankee imperialism" that had long emanated from Central America and the Caribbean. In short, as a U.S. Navy

Caribbean, 1898-1934 (Wilmington: Scholarly Resources, Inc., 2002). See also Healy, Drive to Hegemony: The United States in the Caribbean, 1898-1917.

${ }^{66}$ Frank A. Ninkovich, The Wilsonian Century: U.S. Foreign Policy Since 1900 (Chicago: University of Chicago Press, 1999), 82-85. Also, Lars Schoultz notes that in 1920 "even a casual observer could see that officials in Washington were rethinking the nature of U.S. commitments, spurred by an awareness that the warweary public had grown disenchanted with its Caribbean protectorates." See Schoultz, Beneath the United States: A History of U.S. Policy Toward Latin America, 253.

${ }^{67}$ Tulchin, The Aftermath of War: World War I and U.S. Policy Toward Latin America, 94. Also, Frederick Pike argues that "Undoubtedly, considerations beyond national security influenced policy makers. The 1920s witnessed a re-emergence of the 'older, idealistic view that American businessmen, by their enterprise, would serve...the purposes of stabilization,' thereby making it unnecessary to extend into South America the Caribbean policy of relying on Marines." See Fredrick B. Pike, The United States and the Andean Republics: Peru, Bolivia, and Ecuador, The American Foreign Policy Library (Cambridge: Harvard University Press, 1977), 194. 
history of American naval missions would later conclude, in the 1920s, for the first time it became national policy to employ an arm of the United States military establishment to supplement "the development and expansion of our trade and political relations" and to give practical expression to previously "abstract expressions" of Pan-Americanism. ${ }^{68}$

\section{PERUVIAN INTERESTS: FINANCIAL AND TRADE TIES}

Washington's designs to further expand its trade, investment, and military influence in South America aligned well with the designs of Peruvian President Augusto Leguía, who came into office in July 1919 with three overriding objectives: 1) spurring economic growth through deepened financial and trade ties to the United States; 2) reaching favorable resolutions to Peru's unsettled border disputes, especially with Chile; and 3) entrenching himself in power. The first of these did much to frame Peru's foreign relations from very early on. Having served one previous term (1908-1912) as Peru's president, Leguía returned from exile to win the office again in 1919 on a Patria Nueva ("new fatherland") platform that staked Peru's economic future on export-led growth in its extractive industries (principally oil and minerals), the expansion of Peru's transportation and communications infrastructure, and a substantial expansion of the nation's social safety net. ${ }^{69}$ Essential to Leguía's vision of a prosperous future for Peru was widespread foreign involvement in the inner workings of both the Peruvian economy and government. In his assessment, infusions of foreign capital were necessary to give industrial and infrastructure projects the boost they needed to

\footnotetext{
${ }^{68}$ U.S. Navy, "U.S. Naval Missions to South America," Undated, RG 38, Entry E-194, Box 1, National Archives. Hereafter, this document is cited as "U.S. Naval Missions." Although undated, it is all but certain that this is the history of U.S. naval missions written by William O. Spears (Captain, U.S. Navy) during an assignment in Washington before he joined the U.S. naval mission in Peru in 1929.

${ }^{69}$ Jorge Basadre, Historia de la República del Perú, 1822-1933, 6 ed., 17 vols., vol. 13 (Lima: Editorial Universitaria, 1968). See also Masterson, The History of Peru, 114-15.
} 
overcome the nation's difficult geography, which had long kept Peru's coastal, mountainous, and eastern rainforest regions divided into economically distinct regions. Similarly, he viewed foreign technical expertise as Peru's only hope both for advancing into the realm of "modern" nations and for overcoming the longstanding socioeconomic divisions that flowed from the racial and cultural makeup of Peruvian society. For both capital and technical expertise Leguía looked first and foremost toward the United States. ${ }^{70}$ It was a familiar pattern: during his first presidential tenure Leguía had devoted considerable energy to securing U.S. commercial and government loans to finance his administration's programs, and had invited educators from the United States to assume key positions of responsibility within Peru's public education establishment. ${ }^{71}$

During his second tenure (1919-1930), these same patterns would reemerge on a much larger scale. Between 1920 and 1929, for example, U.S. banks and private firms loaned Leguía’s government more than $\$ 100$ million to finance the ambitious public works, rail and highway construction, and defense projects that were central to the Patria Nueva idea. $^{72}$ Often these loans were made through the sale of bonds in the United States, bonds that, on the one hand, were highly profitable for the brokers who gathered substantial commissions on their sale, but that, on the other, saddled Peru with an increasing debt load

\footnotetext{
${ }^{70}$ In an early conversation with the U.S. Minister in Lima in the fall of 1919, Leguía "expressed the hope that [the] great development which is inevitable in Peru will be participated in by capitalists of the United States. $\mathrm{He}$ is credited with being friendly with all foreigners in Peru, and of being very friendly to foreign enterprises and the introduction of foreign capital." See Foreign Relations of the United States, 1919, Vol. II (Washington, DC: U.S. Government Printing Office), 735. Hereafter, Foreign Relations of the United States volumes are cited as FRUS.

${ }^{71}$ James C. Carey, Peru and the United States, 1900-1962, International studies of the Committee on International Relations, University of Notre Dame (Notre Dame, IN: University of Notre Dame Press, 1964), 24-26.

${ }^{72}$ Ibid., 72. Carey includes a chart of all the major loans floated by U.S. banks to Leguía's government between 1921 and 1928, totaling more than $\$ 100$ million.
} 
that would be difficult to pay back as the decade progressed. ${ }^{73}$ However, even as they left Peru with a crippling debt burden, these massive infusions of U.S. capital (and the infrastructure modernization they facilitated) did help foster impressive economic growth in Peru during much of the 1920 s. $^{74}$ Moreover, they facilitated the importation of the U.S. technical expertise that was so important to Leguía's vision of a prosperous economic future. The first substantial loan his government secured from the United States, for example, came with the condition that an American be appointed to oversee the Peruvian government's fiscal management. This led to the appointment of a U.S. economist, William W. Cumberland, as director of Peruvian customs, adviser on the government budget, and member of the Board of Directors of the Reserve Bank of Peru. ${ }^{75}$ Leguía appears not only to have gone along with this arrangement, but to have helped conceive of it. In the fall of 1919 he had made overtures to the U.S. Minister in Lima about establishing such a reserve bank, and of having it led a U.S. manager. ${ }^{76}$ And on numerous other occasions during his early years in office, Leguía made concerted efforts to attract North Americans with technical and administrative expertise to Peru on the belief that doing so would pave the way for increasing amounts of U.S. investment to flow into the country. ${ }^{77}$ To a significant extent these efforts bore fruit, as U.S. citizens populated key civilian ministries and departments throughout the

\footnotetext{
${ }^{73}$ After the onset of the Great Depression in late 1929, the practical effect of U.S. banks' heavy investments in Peru would be steep, unrecoverable losses. For more on U.S. loans to Leguía's Peru, see Clayton, Peru and the United States: The Condor and the Eagle, 124-27.

${ }^{74}$ Klarén, Peru: Society and Nationhood in the Andes, 241-44.

${ }^{75}$ Drake, The Money Doctor in the Andes: The Kemmerer Missions, 1923-1933, 215.

${ }^{76}$ U.S. Legation in Lima to Secretary of State, October 31, 1919, RG 84, Vol. 175, National Archives.

${ }^{77}$ Lawrence Clayton has written that "On one occasion Leguía said he wished to name an American to direct all the major branches of the Peruvian government." See Clayton, Peru and the United States: The Condor and the Eagle, 105. This sentiment is visible in records of the U.S. Navy and State Department, as well. For example, a November, 1919 Office of Naval Intelligence report states that "Leguía is pro-American and from his own statements believes the American to be a 'superman'." See ONI Memorandum, November 14, 1919, RG 80, File 4492, National Archives.
} 
Peruvian government and, importantly, with Leguía's blessing, took full charge of the Peruvian Navy. ${ }^{78}$

\section{PERUVIAN INTERESTS: SETTLING BORDER DISPUTES}

To understand how a U.S. naval mission in particular fit into Leguía’s broader vision for Peru's future, though, it is also necessary to examine the foundations of the Oncenio's foreign policy. The centerpiece of that policy was a fervent desire to resolve Peru's persistent border disputes with its neighbors, and no border concern was more pressing to Leguía and the nation as a whole than the longstanding one with Peru's southern neighbor, Chile, which had festered since Peru's defeat in the War of the Pacific (1879-1883). ${ }^{79}$ At the heart of the dispute was the mineral-rich province of Tarapacá, which had comprised the southernmost part of Peru before the war but which, along with a vast swath of Bolivia's coastal Atacama Desert, was captured and occupied by victorious Chilean forces during the hostilities. By the Treaty of Ancón (1883) that formally ended the war, Chile was allowed to keep the Bolivian Atacama and most of Tarapacá as spoils of war. ${ }^{80}$ The national fates of the northern provinces of Tacna and Arica, however, were to be decided by a plebiscite held within ten years of the Treaty's ratification by both nations. In the interim, the Treaty

\footnotetext{
${ }^{78}$ For a brief treatment of Leguía's courting of North American expertise, and of the controversy it generated within Peru, see St. John, The Foreign Policy of Peru, 159-60. See also Carey, Peru and the United States, 1900-1962, 81-88. Daniel Masterson notes that Leguía saw U.S. control of the Peruvian navy "would encourage further [U.S.] business ventures" in Peru. See Masterson, The History of Peru, 115.

${ }^{79}$ On the War of the Pacific, see Sater, Andean Tragedy: Fighting the War of the Pacific, 1879-1884. See also Bruce W. Farcau, The Ten Cents War: Chile, Peru, and Bolivia in the War of the Pacific, 1879-1884 (Westport: Praeger, 2000).

${ }^{80}$ The Treaty of Ancón was concluded between Peru and Chile. Peru's wartime ally, Bolivia, was not a party to the negotiations, and was not a signatory to the Treaty. Thus Bolivia's loss of its littoral was concluded without Bolivian consent. Redressing the loss of its coastline has been a consistent theme in Bolivian foreign policy ever since. For more, see Kenneth D. Lehman, Bolivia and the United States: A Limited Partnership, The United States and the Americas (Athens: University of Georgia Press, 1999).
} 
stipulated that Chilean forces would be allowed to occupy both cities until the plebiscite could be held, and this was the heart of the problem that made finding a permanent solution so difficult. Unfortunately, the Treaty's terms on the timing and conduct of the plebiscite were not explicit, stating only that it should be held within ten years. The practical effect of this ambiguity was that Chile could maintain de facto control of both Tacna and Arica indefinitely until the vote was held.

The Treaty's lack of clarity on the plebiscite question led Peru and Chile to arrive at vastly different interpretations of the cities' legal status when in 1893, predictably, the tenyear period passed and no vote was held. With the expiration, Peru quickly declared the pact null and void since no vote was held within the specified timeframe. Chile, on the other hand, claimed that not only had a plebiscite not been a hard requirement of the Treaty in the first place, but that the ten-year window it specified was only a minimum timeframe within which the determining vote could take place. The implication of the Chilean position was that a vote could be held - or not held - at any time in the future and the Treaty of Ancón would not be violated. ${ }^{81}$ While this uneasy status quo no doubt strengthened Chile's de facto hold on Tacna and Arica (both cities were occupied by Chilean forces at the time), the unsettled condition of the dispute persisted and came to define the basic contours of Peruvian-Chilean relations for decades to come. That the Tacna-Arica controversy, which remained at an impasse when Leguía took office in 1919, would play a major part in Peru's foreign policy agenda in the 1920 s therefore comes as no surprise. ${ }^{82}$

\footnotetext{
${ }^{81}$ For detailed explanations of the Tacna-Arica controversy and the Treaty of Ancón's ambiguity on the plebiscite question, see St. John, The Foreign Policy of Peru, 123-27; Clayton, Peru and the United States: The Condor and the Eagle, 137-41.

${ }^{82}$ During his 1919 campaign Leguía had made achieving a favorable settlement for Peru - regaining not just Tacna and Arica, but all of the lost Tarapacá province - his top goal in foreign affairs. See St. John, The Foreign Policy of Peru, 158.
} 
Animated by a desire to gain the upper hand in that long-simmering dispute, once in office Leguía channeled his enthusiasm for all things North American into a concerted effort to secure U.S. naval assistance that would strengthen Peru's strategic position vis-à-vis Chile (among South America's major naval powers) both in the long-term and the short-term. What he sought to do was leverage the power of the United States to enhance Peru's national security in much the same fashion that he was using cozy financial and trade relations to strengthen Peru economically. In this way Leguía's efforts to secure naval assistance from the United States were entirely consistent with the central philosophical thrust of Patria Nueva, a vital component being the importation of U.S. technical expertise and the promise of close, sustained cooperation with Washington.

Leguía wasted no time putting his naval plans into motion. He began lobbying for a U.S. naval mission well before the Woodrow Wilson administration had even extended his government formal diplomatic recognition. ${ }^{83}$ In October of 1919, as he struggled to consolidate his shaky rule after barely three months in office, Leguía approached the interim U.S. Minister to Peru and signaled his intent to request a mission of U.S. naval officers to "reorganize and direct" - not merely to advise - the Peruvian Navy, which he wanted to improve and enlarge. ${ }^{84}$ In this regard the naval mission Leguía was contemplating differed substantially from the purely advisory naval commission the United States had sent to Brazil in 1918, a team of officers whose main purpose was to counsel the Brazilian Navy on the

\footnotetext{
${ }^{83}$ Wilson extended full diplomatic recognition to Leguía's government in the spring of 1920. Although Leguía had won election in May 1919, for reasons scholars still disagree on, he seized power in a coup-like fashion on July 4, 1919. Thus, in extending recognition, Wilson broke with his announced policy that "so long as the power of recognition rests with me the Government of the United States will refuse to extend the hand of welcome to anyone who obtains power in a sister republic by treachery or violence." For Wilson's statement of policy, see Schoultz, Beneath the United States: A History of U.S. Policy Toward Latin America, 241-42.

${ }^{84}$ Interim U.S. Minister to Peru to Secretary of State, October 22, 1919, U.S. Legation Lima, Vol. 175, RG 84, NARA.
} 
establishment of a naval war college. ${ }^{85}$ In December, as the U.S. State and Navy

Departments discussed the desirability of sending a naval mission to Peru, Leguía subtly

pressed Washington for action by making it clear to U.S. officials just how different a

mission to Peru would be: members of a U.S. naval mission to Peru were to have full

authority to reform that nation's naval establishment, meaning they would act in an

"executive" capacity and exercise actual command over the Peruvian fleet. Moreover,

Leguía told the U.S. Minister in Lima, under his leadership Peru would "give preference at all times to the United States regarding the strengthening of Peru in a financial, economical, and political way., 86

Leguía's proposal came as a welcome development to foreign policymakers in the Woodrow Wilson administration, who had made expanding U.S. strategic and commercial influence in South America the cornerstone of Washington's hemispheric policy after World War I. ${ }^{87}$ Indeed, by early 1920 Leguía's Peru looked like the most fertile ground in all of South America for postwar U.S. influence to take root. In mid-January Secretary of State Robert Lansing pressed Navy Secretary Josephus Daniels to accede to Leguía's wishes and allow American naval officers to be sent to Peru. Given the broader thrust of U.S. policy toward Latin America, he argued, the United States should not risk passing on the opportunity and opening the door to the possibility that some other nation (presumably a European nation with a history of military ties to South America) could step into the void and

\footnotetext{
85 “U.S. Naval Missions," 21.

${ }^{86}$ Interim U.S. Minister to Peru to Secretary of State, December 15, 1919, RG 84, Vol. 175, National Archives.

${ }^{87}$ Joseph Tulchin has argued that after World War I, U.S. foreign policy toward Latin America changed fundamentally, pivoting from an overwhelming focus on ensuring political and fiscal stability in the Caribbean to a larger preoccupation with rolling back European influence throughout the hemisphere and paving the way for American economic and strategic penetration of South America. In short, Tulchin concludes, after the war "the sphere of United States interest [in Latin America] now included the entire Western Hemisphere." See Tulchin, The Aftermath of War: World War I and U.S. Policy Toward Latin America, 3.
} 
offer Peru a naval mission. It was a line of argument seemingly designed to provoke a response. Coming out of the recent war in Europe, after all, it had been U.S. military leaders, not diplomats, who had expressed the greatest concern about potential European military encroachment in South America. Here, Lansing was reminding the Navy of that possibility. Passing on Leguía's request, he cautioned Daniels, would make it "more difficult to use our influence toward the betterment of the international situation in South America." 88

The State Department's position on dispatching a naval mission was decidedly more aggressive than that of the U.S. Navy, which, ironically, was the agency expressing concern about the diplomatic effects a U.S. naval mission to Peru might have on regional developments such as the still-tenuous border situation between Peru and Chile. ${ }^{89}$ As Secretary Daniels weighed the State Department's argument, a debate about the diplomatic wisdom of such a mission emerged among naval officers advising both the Secretary and the Chief of Naval Operations. In line with State Department thinking, Lucius Bostwick (Captain, U.S. Navy) advised Chief of Naval Operations Robert Coontz that Leguía's request for a U.S. naval mission should be "seriously considered" by the Navy Department even though the United States could not hope to receive much immediate material return on its investment. In Bostwick's assessment, as in the State Department's, the issue was not immediate payoff but the expansion of U.S. influence, the fundamental questions being

\footnotetext{
${ }^{88}$ Secretary of State (Lansing) to Secretary of the Navy (Daniels), January 14, 1920, RG 59 (State Department Central File), File 823.30/5.

${ }^{89}$ Lawrence Clayton notes that "In the main the United States has supported Peru's positions vis- à-vis Chile, a tradition that goes back to the War of the Pacific when the United States sought to maintain Peru's territorial integrity in the face of the victorious Chileans. The unresolved dispute between Peru and Chile over the disposition of the cities of Tacna and Arica and their territories gave rise to the most famous U.S. arbitration of Peruvian/Chilean affairs this century" - mediation by U.S. President Warren Harding in 1922, an effort continued by his successor, Calvin Coolidge. See Clayton, Peru and the United States: The Condor and the Eagle, 137-38.
} 
whether South American naval establishments like Peru's should be “influenced by our ideas or by the ideas and ethics of our possible enemies, whether we wish them favorably disposed toward the United States or the reverse." 90 Another staff officer, Harry Yarnell (Captain, U.S. Navy), acknowledged the validity of the State Department's position, and recognized that national policy dictated furthering the nation's political and economic interests in Latin America by "all legitimate methods," including naval missions. But owing to the unsettled border situation, he advised that the time was "unsuitable" for establishing a mission in Peru. Another staff officer made the case more clearly: because relations between Peru and Chile were "not cordial," sending a mission to Peru "might easily be considered an affront to Chile" and thus could prove profoundly destabilizing. ${ }^{91}$

Fearful that U.S. naval officers could become embroiled in a border war between the two South American nations, Secretary Daniels at first came down against a mission. In early November he wrote Lansing that, while he agreed in principle with the State Department's position, "the sending of such a mission could not be encouraged at any time when the relations of Peru with any other South American country [Chile] were unduly strained. ${ }^{92}$ To the State Department, the Navy's response was unacceptably cautious. Secretary Lansing and other officials proceeded to apply consistent pressure to change the Navy's position. In late December, Daniels relented. He reiterated his belief that "the present is not an opportune time" to send a mission, but in view of the direction broader U.S.

\footnotetext{
${ }^{90}$ Bostwick cover memo (undated) attached to letter from Assistant Secretary of State William Phillips to Secretary of the Navy Josephus Daniels, October 27, 1919, RG 80 (Secretary of the Navy General Correspondence), File 4492, Box 130, National Archives.

${ }^{91}$ Handwritten comments on routing sheet attached to Secretary of the Navy to Secretary of State, December 24, 1919, RG 80, File 4492, Box 130, National Archives.

${ }^{92}$ Secretary of the Navy to Secretary of State, November 3, 1919, RG 80, File 4492, Box 130, National Archives.
} 
policy toward Peru was heading, stated resignedly that the Navy would be "pleased to assist" national policy by sending a naval mission "at such time as it is considered proper to do so by the State Department."93 Clearly, foreign policymakers in the State Department believed the proper time had long since arrived.

As 1920 dawned, the Navy Department's reluctant approval set the stage for a quick consummation of the longer-term naval partnership Leguía had wanted with the United States. Almost immediately, the Wilson administration began pressing Congress to pass legislation permitting U.S. naval officers to accept employment from South American governments. ${ }^{94}$ And just as quickly, Leguía began urging Washington to expand on the commitment it was then only in the early stages of making. Specifically, Leguía wanted to ensure that the U.S. naval mission chief (who would head the Peruvian Navy) was an officer of sufficiently high rank to ensure that Peruvian officers, who may resent taking orders from a norteamericano, would obey his orders. Leguía had bristled at Washington's initial proposal to make the mission chief a mid-level officer, an offer the U.S. Navy had made out of necessity because it had few high-level officers it could spare for such duty. When, at the State Department's urging, Navy leaders subsequently elevated the position of mission chief to a captain's billet, the Peruvian president was still not satisfied. ${ }^{95}$ In a meeting that month

\footnotetext{
${ }^{93}$ Secretary of the Navy to Secretary of State, December 24, 1919, RG 80, File 4492, Box 130, National Archives.

${ }^{94}$ A bill (S.4435, "An Act to authorize officers of the naval service to accept office with compensation and emoluments from Governments of the Republics of South America") was passed by Congress and signed by President Woodrow Wilson on June 5,1920. The law authorized the President of the United States to detail naval officers to "assist the Governments of the Republics of South America," permitted those officers to accept commissions (rank in foreign navies) and compensation from South American governments, and allowed them to continue to receive pay and time-in-grade (for promotion purposes) from the U.S. Navy while serving in foreign missions. See "Brief Summary of the Activities of the U.S. Naval Mission to Peru from its Inception to 1 November, 1928," (Office of Naval Intelligence), RG 38, A-1 Entry 48-A, Box 4, National Archives. Hereafter cited as Brief Summary, 1928.

${ }^{95}$ Office of Naval Operations Memorandum on Conference Concerning Personnel for Naval Mission to Peru, February 12, 1920, RG 80, File 4492, Box 130, National Archives.
} 
with the U.S. Minister in Lima, he argued that the mission chief should be at least a rear admiral, so as to avoid "jealousies" that might arise with high-ranking Peruvian officers. Such problems had plagued the French military mission that had been advising the Peruvian Army for years, Leguía maintained, and he was "insistent" that the mistake not be made again within the Navy. ${ }^{96}$ Leguía soon backed off on this point, a move that appears to have been related to the fact that, as of March 1920, the United States had still not extended Leguía's government the formal diplomatic recognition he so fervently desired. ${ }^{97}$ Perhaps in an attempt to smooth the way for finally establishing those relations, Leguía soon indicated that, after all, he would be willing to accept an officer at the lower rank of captain or even commander - so long as the mission intended to train Peruvian naval forces "in actual work at sea."98 By May the United States had extended Leguía's government its coveted de jure recognition, and by September the U.S. naval mission was en route to Lima. ${ }^{99}$ The

\footnotetext{
${ }^{96}$ U.S. Minister to Peru to Secretary of State, March 15, 1920, RG 59, File 823.30/10. For more on the French military mission in Peru from 1896 to 1944 (with the exception of a few years in the late 1930s), see Masterson, Militarism and Politics in Latin America: Peru from Sánchez Cerro to Sendero Luminoso, 17-29.

${ }^{97}$ See U.S. Chargé in Peru to Secretary of State, January 18, 1920 and Secretary of State to Peruvian Ambassador in Washington, April 13, 1920, both in FRUS, 1920, Vol. III (Washington, DC: U.S. Government Printing Office), 359-360. It appears that Leguía's fears that recognition would not be forthcoming in the spring of 1920 were unfounded. In a March 10, 1920 memorandum to President Wilson, Under Secretary of State Frank Polk recognized that Leguía had some considerable leverage on Washington: namely, Washington feared European commercial, political, and military penetration of South America. As Polk wrote, "Leguía...does not wish to take any important action without the advices of the United States Government." Moreover, because Britain, France, and several other European nations had already extended Leguía's government formal diplomatic recognition, "longer delay [on the part of the United States] may injure the good relations at present existing between the Leguía government and...cause Leguía to turn to some other country for aid and cooperation." President Wilson signaled his approval of Polk's recommendation to extend recognition by initialing "W.W." on the memo. See Under Secretary of State to President Woodrow Wilson, March 10, 1920, RG 59, File 823.00/369, National Archives.

${ }^{98}$ Director, Office of Naval Intelligence (Niblack) to Chief of Naval Operations, May 5, 1920, RG 80, File 4492, Box 130.

${ }^{99}$ Historian James C. Carey argues that had the United States stuck to President Wilson's policy of nonrecognition of governments that assumed power by force, "it is doubtful that Leguía would have been recognized" when he was. In Carey's analysis, Leguía's strong pro-Americanism, especially in the economic realm, explains the deviation from Wilson's established policy. See Carey, Peru and the United States, 19001962, 40.
} 
foundation for a more than decade-long naval partnership between Peru and the United States was established.

As important as a close, cooperative naval relationship with Washington was to Leguía's longer-term security aims, his more immediate concern in late 1919 and early 1920 was procuring vessels and armaments from the United States that could help even the naval balance with Chile immediately. ${ }^{100}$ In 1919 it appeared that Chile had recently acquired six submarines from Great Britain and was in the process of acquiring additional surface vessels to augment its fleet. ${ }^{101}$ If true, Leguía feared, these reports meant Chile was on the cusp of achieving a position of significant strategic advantage over Peru, which possessed only two aging, largely inoperable French-built submarines (acquired during his earlier presidential term) and a thoroughly inferior surface fleet. ${ }^{102}$ The revelation of Chile's emerging naval superiority no doubt heightened Leguía's fears for Peru's security, as memories of its defeat in the War of the Pacific and insecurities over the still-unresolved border dispute lingered in the Peruvian national consciousness. As a new technology that had proven its worth as a decisive instrument of modern naval warfare in the recent war in Europe, submarines appeared to Leguía to be the fastest and most efficient means of increasing the lethality of

\footnotetext{
${ }^{100}$ Robert Scheina argues that Leguía's request of a U.S. naval mission was motivated by a desire to build Peruvian military and naval strength vis-à-vis Chile. See Scheina, Latin America: A Naval History, 1810-1987, 127.

${ }^{101}$ Chile had contracted with British firms for a number of submarines and surface vessels before the outbreak of World War I. When the war began, Britain seized those vessels for its own purposes and promised either their return or fair compensation after the war. In 1918, Britain delivered six submarines to Chile, and in 1920 it sold Chile one dreadnaught, three destroyers, and a tug for less than half of those vessels' market price. See Telegram from U.S. Embassy in London to Secretary of State, August 20, 1918, RG 59, File 825.34/218, National Archives. See also Secretary of Navy to Secretary of State, June 14, 1920, RG 59, File 825.34/232, National Archives.

${ }^{102}$ Peru attempted to purchase submarines from the United States during Leguía's earlier presidential term (1908-1912) but was forced to abandon the plan due to financial constraints. See Clayton, Peru and the United States: The Condor and the Eagle, 85-86. Peru ended up acquiring two submarines from France, the Ferré and Palacios, in 1913, but both boats were rendered inoperable when, during World War I, the Peruvian government was unable to acquire replacement batteries to power the vessels while submerged. See Ortíz Sotelo, Apuntes Para la Historia de los Submarinos Peruanos, 39-63.
} 
Peru's small naval fleet. ${ }^{103}$ Being deficient in submarines to Chile was therefore unacceptable. $^{104}$

The naval balance with Chile was such a concern, in fact, that Leguía had begun inquiring about purchasing submarines in the United States more than four months before his July 4, 1919 ascent to power. In March of that year, through an intermediary, Leguía had sought basic data on submarines from the Electric Boat Company (Groton, Connecticut) on the idea that, once in office, he might acquire several for the Peruvian Navy in order protect Peru from a growing Chilean threat. ${ }^{105}$ He continued this push for submarines after assuming the presidency. In the late months of 1919, even as he struggled to shore up his shaky hold on power, Leguía unsuccessfully sought to contract with the Electric Boat for two submarines. ${ }^{106}$ At the same time, hedging his bets, he reached out to Italian shipmaker

\footnotetext{
${ }^{103}$ Although submarines were clearly his higher priority, Leguía also initiated a push in 1920 to acquire surface vessels in the United States. In the winter of 1919-1920 he proposed buying modern oil-burning surplus surface ships directly from the U.S. Navy, and after it became apparent that the Wilson administration was not willing to make such a sale because of concerns over destabilizing Peruvian-Chilean relations, he began working his government's increasingly close connection with the Electric Boat Company. In March, 1920 the Peruvian ambassador to Washington, Federico Alfonso Pezet, approached Electric Boat about buying four destroyers the company had purchased from a U.S. government "scrap sale" and refurbished for resale. (See Electric Boat Company to Pezet, March 24, 1920, Munitions Industry: Hearings Before the Special Investigating the Munitions Industry, Vol. 1, 346.) In the same May 1920 communication in which he had pitched the idea of acquiring U.S. submarines for instructional purposes, naval attaché Aubry also signaled Leguía's interest in purchasing six submarine chasers and four oil-burning destroyers "of the older type" from Electric Boat if the U.S. Congress gave its approval. As he did with his pursuit of submarines, Leguía also approached the U.S. Navy directly, hoping to secure four surplus surface vessels for a lower price, only to run into the same objections the Wilson administration had raised about selling his government submarines.

${ }^{104}$ In an April 29, 1920 meeting with Secretary of State Bainbridge Colby, Peruvian Ambassador Pezet viewed Chile's acquisition of submarines and surface vessels from Britain with grave concern. He argued that "Chile was maintaining an entirely unnecessary armament and was nursing aggressive designs which would be troublesome to the United States [as well as Peru] in a period of ten years or less." See Secretary of State Memorandum of Conversation, April 29, 1920, RG 59, File 825.34/224, National Archives.

${ }^{105}$ Henry R. Carse (President, Electric Boat Company) to L.Y. Spear (Vice President, Electric Boat Company), March 29, 1919, Special Committee to Investigate the Munitions Industry, U.S. Senate, Munitions Industry: Hearings Before the Special Committee Investigating the Munitions Industry, United States Senate, Seventythird [-Seventy-fourth] Congress, pursuant to S. Res. 206, a Resolution to Make Certain Investigations Concerning the Manufacture and Sale of Arms and Other War Munitions, 1934, 85-86.

${ }^{106}$ Allen Gerlach, "Civil-Military Relations in Peru: 1914-1945" (Ph.D. Dissertation, University of New Mexico, 1973), 154.
} 
Laurenti about the possibility of procuring several of its submarines, perhaps as a way of strengthening his hand in negotiations with the United States (his preferred source) by playing on Washington's underlying concerns about resurgent European military influence in South America. ${ }^{107}$ Several months later, just as negotiations with Washington for a U.S. naval mission were coming to a fruitful conclusion, Leguía's naval attaché in Washington, Luis Aubry, approached the U.S. government directly about purchasing active submarines from the U.S. Navy's fleet. ${ }^{108}$ By mid-1920, however, the U.S. State Department had begun to share in some of the regional concerns that had been expressed earlier by the Navy Department: with a U.S. naval mission headed to Lima to take over administration of the Peruvian Navy, it would be imprudent to approve more overt naval support (such as armaments) for Leguía's government. Taken so closely on the heels of the decision to send a naval mission, such action could destabilize Peruvian-Chilean relations that had long been tense over Tacna-Arica. ${ }^{109}$

This turn in U.S. policy set off a flurry of activity that clearly demonstrates both the urgency Leguía attached to immediate naval expansion and the shrewdness with which he moved to achieve it in his relations with Washington. Rather than taking no for an answer and abandoning his plans to acquire submarines in the United States, in the face of Wilson

\footnotetext{
${ }^{107}$ Commander Lewis D. Causey, Report on “U.S. Naval Mission to Peru," RG 80, File 26255-611, Box 1612, National Archives, 1.

${ }^{108}$ As the U.S. Congress debated the bill that would permit the Wilson administration to send a naval mission to Peru, the Peruvian ambassador in Washington, Pezet, notified the State Department regarding Leguía's willingness to purchase submarines from the United States for instructional purposes. See Office of Naval Intelligence Memorandum to Secretary of the Navy, May 17, 1920, RG 59, File 823.34/61, National Archives.

${ }^{109}$ In June, 1920, the Electric Boat Company's vice-president, L.Y. Spear, wrote to his superior, H.R. Carse, that Peruvian Ambassador Pezet was "cabling the Government [of Peru] that the United States has definitely decided as a matter of policy not to supply anything either to them [the Peruvians] or to Chile on the score that this might be encouraging an outbreak of war between them." See L.Y. Spear to H.R. Carse, June 1, 1920, Munitions Industry: Hearings Before the Special Committee Investigating the Munitions Industry, United States Senate, Seventy-third [-Seventy-fourth] Congress, pursuant to S. Res. 206, a Resolution to Make Certain Investigations Concerning the Manufacture and Sale of Arms and Other War Munitions, 347.
} 
administration opposition Leguía simply began working around the U.S. government by cultivating closer direct ties with the Electric Boat Company and leveraging its connections to New York banks that might have an interest in financing a sale of submarines to Peru. He was encouraged in this regard by advice from Albert P. Niblack (Rear Admiral, U.S. Navy), director of the Office of Naval Intelligence, who was less reserved about supporting Leguía with naval aid than his State Department and fellow Navy colleagues were. In light of the Wilson administration's opposition to selling Peru naval armaments, Niblack advised Alfonso Pezet, Peru's Ambassador in Washington, that, for Peru, "it was now a matter of Peru going into the market" to buy submarines and destroyers to meet the nation's urgent security needs. ${ }^{110}$

This is precisely what Leguía set about doing. First, he agreed in principle directly with Electric Boat to order four new boats of the 912-ton type, which at the time were the largest and most modern submarines the company produced. To pay for the order, Leguía authorized his naval attaché in Washington, Aubry, to negotiate directly with private banks in the United States for a loan in the amount of $\$ 15$ million to cover the purchase price. ${ }^{111}$ However, Aubry's efforts to secure financing through banks in New York - aided by Electric Boat Company representatives eager to complete the sale - quickly ran into trouble. In late July one of the company's vice presidents, Henry R. Sutphen, informed his superiors that after meetings with representatives of banks that had interests in South America, the outlook for a loan for the Peruvian government to acquire submarines was poor. He wrote that in a meeting he had with representatives of the City Bank of New York, bank officials reported

\footnotetext{
${ }^{110}$ In light of Chile's recent naval acquisitions, Niblack characterized Peru's security situation "helpless," and noted that "the whole balance of power [in South America] has been destroyed by Chile getting six submarines and two warships from England." See Frederick E. Chapin (Electric Boat Representative in Washington, DC) to L.Y. Spear, June 3, 1920, ibid., 348.

${ }^{111}$ Frederick E. Chapin to L.Y. Spear, July 16, 1920, ibid., 348-49.
} 
having turned down similar loan requests from Leguía's government some months earlier because of the Peruvian government's "poor financial position." In that earlier instance, City Bank had viewed the loan request as simply too large in relation to the nation's existing external debt of $\$ 34$ million. Adding nearly 50-percent to Peru's national debt so its government could purchase of vessels of war would be a mistake, the bankers had concluded, especially in light of the fact that Peru had already "hocked almost everything she own[ed]" and would in all probability be unable to repay the loan. ${ }^{112}$ Other banks shared this sentiment, viewing the Peruvian government's finances with a great deal of skepticism. Nevertheless, Leguía remained "insistent" on obtaining submarines, going so far as to tell representatives of Electric Boat that if he could not secure financing in the United States then "the people of Peru will take the loan."

Sensing that the sale was in trouble, Electric Boat Company representatives went to great lengths in search of a financial solution that would permit Leguía's government to receive the funds it needed to make the purchase. First, company president Henry R. Carse floated the idea of seeking funds from a firm with an interest in oil exploration in Peru. Under such a deal, he wrote to his representative in Washington, Leguía's government would grant an oil concession to a foreign (presumably U.S.) firm in exchange for the money needed to purchase submarines. ${ }^{114}$ Although idea was consistent with Leguía's Patria Nueva vision of economic development, it appears to have never made it out of the concept stage because Leguía had not given up on the idea of securing a large loan from a New York bank. His preferred strategy was to improve the appearance of Peru's financial standing in order to

\footnotetext{
${ }^{112}$ H.R. Sutphen to L.Y. Spear, July 20, 1920, ibid., 351.

${ }^{113}$ F.E. Chapin to H.R. Carse, August 7, 1920, ibid., 352.

${ }^{114}$ H.R. Carse to F.E. Chapin, August 6, 1920, ibid., 353.
} 
make it look more creditworthy to prospective lending institutions. This was the impetus behind Leguía's decision to have his ambassador to the United States deposit in a Washington, D.C. bank the proceeds (approximately $\$ 2$ million) from the transfer by Peru to the U.S. Shipping Board of a German vessel that had been detained in the port of Callao during the recent World War. Carse saw the maneuver for what it was - an attempt to make Peru look like less of a lending risk. ${ }^{115}$

Neither this infusion of cash nor the oil concessions idea produced the financing both Leguía and Electric Boat so fervently desired for Peru. Indeed, none of Leguía’s efforts to acquire submarines in his first two years in office yielded the results he sought. But, determined to build up Peru's Navy, the Peruvian president continued to press Washington to sell him naval hardware. ${ }^{116}$ As will be explained in Chapter 2, these early attempts laid the groundwork for the successful submarine deals his government would conclude with the Electric Boat Company - with the active support and assistance of the U.S. naval mission to Peru - in later years. That those later purchases would take place at all given U.S. concerns about destabilizing the fragile Tacna-Arica situation is yet another indication of Leguía's determination to exert some measure of control in his relations with Washington.

\section{PERUVIAN INTERESTS: ESTABLISHING A DICTATORSHIP}

While U.S. naval support became a visible symbol of Patria Nueva and clear evidence of Leguía's efforts to leverage the power of the United States in Peru's ongoing

\footnotetext{
${ }^{115}$ See F.E. Chapin to H.R. Carse, October 25, 1920 and H.R. Carse testimony, both in ibid., 104, 353-54.

${ }^{116}$ In an official dispatch from Washington in November, 1919, Ambassador Pezet informed Peru's Ministry of Foreign Relations that despite opposition from President Wilson and his cabinet, he had not lost sight of acquiring destroyers for Peru's navy, had returned periodically to the issue since the summer, and was deploying new arguments in an attempt to gain the favor of Secretary of State Bainbridge Colby and Navy Secretary Josephus Daniels. See Peruvian Ministry of Foreign Relations to Senior Minister of the Peruvian Marine, December 30, 1919, RG 38, Entry 194, Box 1, National Archives.
} 
difficulties with Chile, it also helped him strengthen his domestic political position and establish a long-lasting dictatorship. Peru's military establishment had become a powerful force in the nation's political life in the early $20^{\text {th }}$ century. The Peruvian Army, for example, had long been under the tutelage of a French military mission that, although it espoused the French military ethic of obedience of military to civilian authority, was nevertheless imbued with characteristics peculiar to the French Army's overseas colonial service: a keen awareness of its own institutional interests, a firm sense of social mission, and a penchant for political activism. ${ }^{117}$ This mix of values took root and grew as the Peruvian Army professionalized on the French model, a process most clearly visible in the golpe (coup) led by then-Colonel Oscar R. Benavides against civilian president Guillermo Billinghurst February 1914. Launched in response to Billinghurst's cuts to military budgets and his attempt to reign in growing Army opposition by arming working class militia, the Benavides golpe demonstrated, in the words of historian Daniel Masterson, that Peru's newly professionalized Army “could not remain aloof from the nation's partisan political struggles” and "would enter the political arena once its corporate interests were threatened." 118 This willingness to involve itself in the nation's politics remained a hallmark of the Peruvian Army amid both the political instability that followed Billinghurst's overthrow and the economic change that accompanied World War I. When Leguía looked to regain the

\footnotetext{
${ }^{117}$ Daniel Masterson has noted that "The French colonial officer served more as an administrator than a combatant. More significantly, he frequently acted independently of Paris and consequently developed administrative competence and a concomitant contempt for remote civilian leaders who failed to comprehend the problems posed by restive indigenous populations in the colonies." A number of the French officers posted to the military mission in Peru, Masterson argues, had had experience in colonial service in France's African colonies. As a result, the prescription they offered the Peruvian Army was a mix of not just of military professionalism and modernization on the French model, but a philosophy of obedience to civilian authority that differed from the rigid model adhered to in France proper. Masterson further argues that this "French army 'school', enriched by the ideas and experience of its colonial soldier-administrators, became the seedbed for Peruvian military professionalism" in the $20^{\text {th }}$ century. See Masterson, Militarism and Politics in Latin America: Peru from Sánchez Cerro to Sendero Luminoso, 26-27.

${ }^{118}$ Ibid., 29.
} 
presidency in early 1919, he naturally viewed Army support as a double-edged sword something he had to have in order to reach power, and something he had to carefully manage in order to retain it.

In office, Leguía therefore sought to keep the Army happy while at the same time neutralizing its ability to disturb his grip on power. ${ }^{119}$ In short order he initiated substantial budget increases for the Army and, in a process that would continue throughout his rule, began systematically purging its officer corps of potentially dangerous figures while showering rewards on those officers he deemed politically loyal. ${ }^{120}$ Moreover, the energy Leguía poured into reforming and expanding Peru's Navy to strengthen it vis-à-vis Chile played perfectly into his early efforts to weaken the Army as a potential source of political opposition. In August 1919, after barely a month in power, he removed the Navy from the jurisdiction of the Ministry of War and established a separate Ministry of Marine with a political loyalist at its head. ${ }^{121}$ It was shortly after this that he began courting a naval mission from the United States, promising its officers complete control over the entire naval establishment. And only a matter of months after the U.S. naval mission arrived in Lima, Leguía reorganized the fledgling Ministry of Marine to ensure that the North American officers' control would be complete. In a January 17, 1921 decree he established a Naval

\footnotetext{
${ }^{119}$ To a significant degree, Leguía owed his return to power to the Peruvian Army, which helped him overthrow President José Pardo in the early morning hours of July 4, 1919. See U.S. Consul General at Callao-Lima to Acting Secretary of State, July 4, 1919 (3:00pm), FRUS, 1919, Vol. II, 721. In August, 1919, after Leguía had been in power for approximately six weeks, the U.S. Minister in Lima wrote the Secretary of State on the early dealings of Leguía's provisional government, noting that the Peruvian Army had been a major political player in determining the fates of Peru's three previous presidents, and would likely remain one in the future. See U.S. Minister to Secretary of State, August 19, 1919, RG 59, File 823.00/301, National Archives.

${ }^{120}$ For example, in 1921 Leguía sent Benavides into exile, and shortly thereafter assigned Lieutenant Colonel Luis M. Sánchez-Cerro (a junior officer thought by Leguía to be politically dangerous) to overseas duty studying foreign military establishments. See Masterson, Militarism and Politics in Latin America: Peru from Sánchez Cerro to Sendero Luminoso, 32-34.

${ }^{121}$ Gerlach, "Civil-Military Relations in Peru: 1914-1945," 153.
} 
General Staff whose head position, that of chief of staff of the Peruvian Navy, would be filled by the head of the U.S. naval mission. The chief of staff was to have "direction over and administration of the entire Navy," and his orders were to have "all the force and effect" of directives that came from the Minister of Marine himself. In an indication of just how close Leguía intended to keep the naval mission to the center of power, the decree stipulated that the naval mission chief, as Navy chief of staff, was to attend all meetings the president held with his civilian Minister of Marine. ${ }^{122}$ The Lima opposition newspaper, La Prensa, called this particular aspect of the decree "a real resignation of the ministerial function" and a "humiliating delegation of sovereignty," but the result was just as Leguía had envisioned it. ${ }^{123}$ The United States now had a direct, tangible stake in his regime.

With the U.S. naval mission in place and the Peruvian Navy firmly under the command of U.S. officers, who even held Peruvian commissions and wore Peruvian uniforms (see Appendix 1, Photo 2), the basic structure through which U.S.-Peruvian relations would be conducted for the remainder of the decade was in place. Importantly, Leguía had achieved his goal of linking Peruvian security, and the political security of his

\footnotetext{
${ }^{122}$ Brief Summary, 1928, Enclosure E, 1-2. Leguía's decree spelled out in detail that the naval directorates of "Operations, Personnel, Material, Administration, Medical Service, Port Authorities, and Accounts of the Ministry, shall be under the immediate jurisdiction of the Chief of the General Staff." Also, it established a "Naval Division" (fleet) consisting of the navy's few serviceable vessels. Finally, it appointed (by name) the first senior members of the U.S. naval mission to all key positions within the General Staff: Captain Frank B. Freyer as Chief of the General Staff, Captain Lewis D. Causey as General Commandant of the Naval Division, and Captain Charles G. Davy as Director of the Escuela Naval (naval academy). The opposition press in Lima, which at that time was still active, responded forcefully.

${ }^{123}$ In its January 21, 1921 edition, La Prensa called the new powers granted to U.S. officers "a real resignation of the ministerial function," and argued that the Minister of Marine "has nothing left to do, has no duties to perform and no authority to enforce in the Navy. Hereafter the Chief of Staff thus created, a position held at present by an officer ranking high in the American Navy, will do it all. From a patriotic point of view the Decree proves unacceptable, as no one can consent to so humiliating a delegation of sovereignty. However poor our resources, however great our lack of efficiency, however high our ambitions for the future, it is we who are called upon to rule ourselves and to automatically carve out our happiness or ruin." See "An Anticonstitutional Decree," reproduced in U.S. Ambassador (Gonzales) to Peru to Secretary of State, January 26, 1921, RG 59, File 823.30/20, National Archives.
} 
regime, to the United States. It was a favorable arrangement for the Peruvian president, whose mutually reinforcing objectives at every turn were developing an ever-closer relationship with the United States and consolidating his hold on power. Beginning in early 1921 Leguía set himself firmly about the task of achieving both. Through measures substantive and symbolic, he continued to curry favor with the U.S. financial and political establishments even as he moved to crack down on internal dissent. In 1921, for example, he secured his first major loan from a U.S. bank, the Guaranty Trust Company of New York, and, as noted earlier, received a North American as director of Peruvian customs and adviser on government finances. A more sizeable loan from the Guaranty Trust Company followed the next year - the result of productive lobbying both in New York and Washington, and a success that paved the way for the much larger loans that would flow to Peru throughout the rest of the decade. ${ }^{124}$ At the same time, Leguía sought to fertilize the growing U.S. economic involvement in Peru with symbolic acts designed to ingratiate himself with the United States and gain further validation of his rule. For example, on the occasion of three U.S. Navy destroyer divisions' visit to the port of Callao in January 1921, Leguía declared a national holiday and arranged what the New York Times called "an enthusiastic reception, the docks being crowded with people who commented on the fine impression made by the little war vessels." 125 The next year, he presented as a gift to the city of Lima a copy of French artist Jean Antoine Houdon's famous 1788 sculpture of George Washington, as “a testimonial to the American hero and to American ideals."126 And later, in honor of the United States he

\footnotetext{
${ }^{124}$ Tulchin, The Aftermath of War: World War I and U.S. Policy Toward Latin America, 198-204. See also Carey, Peru and the United States, 1900-1962, 71-74.

125 "Chile and Peru Hail American Warships: Pacific Fleet at Valparaiso-Atlantic Fleet Turns Off for a Visit to Callao," New York Times, February 1, 1921, 17.

${ }^{126}$ U.S. Embassy in Peru, "Monthly Report on General Conditions Prevailing in Peru During the Previous Month,” RG 59, File 823.00/422, National Archives.
} 
declared the fourth of July a Peruvian national holiday and hung a large portrait of President James Monroe (architect of the Monroe Doctrine) in the presidential palace. ${ }^{127}$

Leguía took these calculated measures as he continued to ratchet up pressure on his domestic political opposition. Following an uprising in the eastern Amazon port city of Iquitos early in 1921, he moved swiftly to crush dissent against his government, beginning with attacks on the opposition press. In March Leguía accused the owners of La Prensa, which had often been critical of his rule, of complicity in anti-government revolts, and promptly dispatched government forces against its offices. ${ }^{128}$ Decreeing it "urgently necessary to eliminate centers of conspiracy," in a single day Leguía loyalists expropriated the newspaper's assets, assumed control of its facilities, and resumed publishing - albeit with a strongly pro-government editorial bent. ${ }^{129}$ Such repression continued throughout the year.

U.S. engagement with Leguía's government only grew as the dictatorial nature of his rule came more clearly into focus. Indeed, the only debate that unfolded in Washington regarding the naval mission as Leguía moved against his political enemies was what position its members should assume in the event of revolutionary disturbances. At no point did the State Department or the U.S. Navy consider recalling the mission, or even discuss whether the United States should continue lending support to such an increasingly repressive regime. The U.S. naval officers' presence in Peru was seen too valuable to contemplate a recall. Accordingly, U.S. foreign policymakers attempted to find a solution that would permit the mission to remain, but that would ensure that American personnel did not become engulfed

\footnotetext{
${ }^{127}$ Drake, The Money Doctor in the Andes: The Kemmerer Missions, 1923-1933, 216.

${ }^{128}$ See U.S. Ambassador to Peru to Secretary of State, March 23, 1921, RG 59, File 823.00/381, National Archives.

${ }^{129}$ See "Refugees Report Peru Dictatorship: President Leguía is Declared to Have Usurped Powers and Exiled Opponents," New York Times, April 23, 1921, 18. See also U.S. Ambassador to Peru to Secretary of State, March 24, 1921, RG 59, File 823.00/382, National Archives.
} 
in a civil or foreign war that could prove embarrassing to Washington. The State

Department's chief legal officer identified the heart of the challenge confronting U.S. policy, which was inherent in the naval mission members' dual status as officers in both the Peruvian and U.S. navies: by the contracts the officers signed with the Peruvian government, he wrote, they were for all intents and purposes Peruvian officers and "seem[ed] to be obligated to fight for the present Peruvian Government if the necessity arises." ${ }^{" 130}$ Such involvement in a foreign nation's armed conflict would be clearly unacceptable. Secretary of State Charles Evans Hughes agreed, declaring that it would be "exceedingly unfortunate" if officers of the U.S. Navy served in naval operations in support of a revolution against Peru's government, in suppression of such a revolution, or in a Peruvian war against another South American nation. The obvious solution, he believed, was to develop more stringent contracts when - not if - the mission was renewed after its initial two-year stint in Lima expired in 1922. Until that time, Hughes concluded, "the judgment and discretion" of the mission's officers should govern their conduct, and they "should never allow themselves to be placed in a position, by the Peruvian Government, where they might be called upon to take part in naval engagements in either domestic or foreign war."131

That Washington did not consider withdrawing U.S. naval support from Leguía is not surprising, given the amount of effort he had put into courting the United States, and especially in light of the direction broader U.S. policy toward Peru was trending in the early 1920s. By the end of 1920 it was becoming clear that the United States was fully invested in Leguía's success. In December of that year, after more than twelve months of increasingly

\footnotetext{
${ }^{130}$ See State Department Solicitor Letter to Secretary of State, February 15, 1922, RG 59, File 823.30/23, National Archives.

${ }^{131}$ Secretary of State to American Charge d'Affaires in Lima (Sterling), March 13, 1922, RG 59, File 823.30/24, National Archives.
} 
close relations between Washington and Lima, the Latin American Affairs Division of the State Department recommended that the Secretary of State issue some statement reaffirming U.S. "intolerance" for armed uprisings against governments (such as Leguía's) of "established authority." This was an ironic move, given that Leguía had come to power in an Army-backed coup and received de jure recognition from Washington within a year despite Wilson's general policy not recognizing governments that had come to power by force. ${ }^{132}$

The deepening U.S. commitment to Leguía was based on more than compatible economic and political visions of the future. There was a distinct racial component underlying it that suggested to U.S. policymakers that Leguía's dictatorial methods were not so much a nuisance that U.S. policy had to live with, but, rather, were the right prescription for the infirmities that had long ailed Peru. This racial underpinning is clearly visible in correspondence between U.S. diplomats in Lima and Washington in the early 1920s. The U.S. Chargé d'Affaires in Lima in 1921, Frederick Sterling, gave U.S. views their clearest expression in a remarkable dispatch to Secretary of State Charles Evans Hughes that December - a moment when, amid Leguía's assaults on his political foes, Sterling deemed it appropriate to consider "what type of government is best suited to the development of Peru." Ninety-percent of Peruvian society consisted of either "pure Indians" or "mestizos," he wrote, and of the ten-percent who could be considered "white," only one-tenth (or, onepercent of the society as a whole) could be "classed as intelligent, having a national consciousness and a desire for the development of the country on modern lines." This social fabric, Sterling suggested, had long prevented "steadfast principles of government" from taking root in Peru and had consigned the country to a history of chronic political instability

\footnotetext{
${ }^{132}$ Latin American Affairs Division to Secretary of State, December 1, 1920, RG 59, File 823.00/377, National Archives.
} 
and economic stagnation. Given this poor outlook, he urged, it was worth considering whether or not "during its present state of civilization" Peru was "not better served by an honest and progressive, if autocratic, administration" such as Leguía’s. After all, Leguía was a son of the one-percent of Peruvians Sterling had classified as "intelligent." And as the ardently pro-American Peruvian president had clearly demonstrated, he had the national consciousness and desire for "modern" development that Washington foreign policymakers increasingly believed could only come from embracing the U.S. model of development. ${ }^{133}$ Moreover, Sterling continued, Leguía had the foresight to recognize that without firm leadership, Peru would remain mired in the socioeconomic "weakness and inefficiency" toward which its society's racial make-up naturally inclined it. Thus, Leguía’s political purges and deportations, attacks on the opposition press, and demonstrated "firm intention to maintain his power at any cost" were, in Washington's view, simply harsh but necessary medicine. Sterling concluded that the dictator was "the ablest president that Peru has had for many years," and deserved the "entire support" of the United States. ${ }^{134}$ Thus did the United States continue, through its naval mission and other measures, to involve itself intimately in the inner workings of the Peruvian state even as it recognized the dictatorial nature of the government its support was strengthening.

\footnotetext{
${ }^{133}$ For more on U.S. foreign policymakers' growing belief after World War I that U.S. values and the U.S. model of development could and should be exported globally, see Ninkovich, The Wilsonian Century: U.S. Foreign Policy Since 1900.

${ }^{134}$ See U.S. Chargé d'Affaires in Peru to Secretary of State (Confidential), November 29, 1921, RG 84, Vol. 182, National Archives. Little more than a year later, the U.S. Ambassador reported to Washington that Leguía was engaging in further repression, but noted that "the drastic measures used by the government" had made revolution unlikely, and that the Army and Navy were "temporarily satisfied" by substantial budget increases. See U.S. Ambassador to Peru to Secretary of State, January 5, 1923, RG 59, File 823.00/429, National Archives. And later in 1923 the U.S. Ambassador affirmed the soundness of the U.S. backing of Leguía, writing to Washington that "whatever may be the arbitrary policy of the President and the improvident and at times dishonest actions of Government officials, it can be stated that Peru is not yet prepared for full democratic government, that Leguía has the best interests of his country at heart, and that his administration is as good as former Peruvian governments, if not better." See U.S. Ambassador to Peru to Secretary of State, June 16, 1923, RG 59, File 823.00/434, National Archives.
} 


\section{CONCLUSION}

The U.S. naval mission that took charge of the Peruvian Navy in 1920 was the product of a convergence of interests between Washington and Lima. Intent on promoting his Patria Nueva vision of national development, President Leguía believed that the mission's presence in Peru would strengthen U.S. investors' confidence in the country and would enhance its prospects for receiving the infusions of capital he deemed necessary to facilitate long-term economic growth. At the same time, he saw the mission as a vehicle for strengthening Peru's position in its long-simmering border dispute with Chile, and by extension, for enhancing the nation's security. A student of Peru's naval history, Leguía knew that the mountains and desert comprising the Peruvian-Chilean frontier made a land invasion of Peru from the south virtually impossible, and that, during the War of the Pacific, Chilean ground forces had been able to land on Peruvian shores and march to victory only after the Chilean Navy had destroyed Peru's fleet in battle at sea. Thus Peru's national security depended on strong naval defenses. In Leguía’s view, having U.S. personnel in positions of command authority over the entire naval establishment gave Peru the greatest chance to successfully overhaul its fleet and achieve meaningful naval reform that would render the Peruvian Navy capable of serving as the backbone of the nation's defenses. Strengthening the Navy as an institution, the president knew, would yield domestic political benefits as well. Specifically, it would cultivate the Navy as a valuable political ally and would aid his efforts to undercut the significant influence exercised by the Peruvian Army in national politics. In this way, Leguía saw the presence of the U.S. naval mission an important step toward consolidating his own political position and achieving the overriding goal of entrenching himself in power. 
For its part, the administration of U.S. President Woodrow Wilson viewed the sending of a naval mission to Peru as an opportunity to provide meaningful assistance to an enthusiastic ally, and as a means of advancing its postwar goal of expanding U.S. strategic and commercial influence throughout Latin America. The goal was to fill the void left by the wartime retreat from South American military and commercial affairs of European nations such as Britain that had historically maintained intimate ties on the continent. Leguía's Peru, with its seemingly insatiable appetite for North American capital and know-how, looked like an ideal point of embarkation for putting this plan into motion. From the perspective of U.S. foreign policymakers, a naval mission in Peru would help pave the way for increasing amounts of American investment in Peru, and would aid in the expansion of U.S. trade in South America. U.S. Navy leaders were initially less enthusiastic about the idea, but did worry about a possible resurgence in European military and naval involvement in South American nations. In the end, the diplomats and the sailors agreed that a naval mission would be an appropriate tool for advancing U.S. objectives in Latin America beyond the traditional sphere of U.S. influence in the Caribbean: it would give Washington an unprecedented opportunity to influence an important South American nation from within, and because it was invited by a friendly government, would not suffer from the problems that had long plagued armed U.S. interventions further north.

To the officials in the U.S. State Department and the U.S. Navy who orchestrated the naval mission to Peru, the potential rewards of this new type of arrangement were well worth the risks Washington would assume. Early in the mission's tenure in Lima, both agencies acknowledged the complications that could flow from having U.S. personnel become officers in Peru's Navy - especially if, as seemed possible, Peru went to war with a neighbor or a 
revolution broke out against the Leguía government. Together, they took steps designed to insulate the naval mission from these potentially dicey situations. They saw no problems, however, with offering overt support (which the naval mission clearly was) to a dictator (which, very early on, Leguía revealed himself to be). Unencumbered by any worries in this regard, in short order members of the U.S. naval mission set themselves about the task of completely reforming the Peruvian Navy. Their efforts would further strengthen ties between the United States and Leguía, help fortify his autocratic rule, and lay the groundwork for a fruitful long-term relationship between the U.S. and Peruvian navies. 


\section{CHAPTER 2: THE WORK OF THE U.S. NAVAL MISSION TO PERU, 1920-1930}

The U.S. naval advisory mission sent to Peru in 1920 was a primary vehicle through which Washington exercised influence and promoted its interests in that nation during the Oncenio of President Augusto Leguía. At the same time, it served as the principal mechanism through which Leguía secured the naval assistance he wanted from the United States, advanced his naval priorities, and ultimately, helped strengthen his hold on power. That the United States and Leguía each succeeded in using the naval mission to secure their objectives is clear from the things the mission accomplished during its more than twelve-year stint in Lima. From the time of its arrival in 1920 until Leguía's overthrow in 1930, U.S. naval officers directed a wholesale transformation of the Peruvian Navy on the U.S. model, establishing enduring organizations and traditions that have served, as Peruvian scholar Jorge Ortiz Sotelo has noted, as the "backbone" of the Peruvian Navy ever since. ${ }^{1}$ Serving simultaneously in the U.S. and Peruvian navies and enjoying complete authority to effect change as best they saw fit, naval mission members threw themselves into the work of instituting meaningful, long-term reform patterned on U.S. Navy values and traditions, and in support of the broader U.S. policy goal of cultivating long-term influence for the United States in Peru.

\footnotetext{
${ }^{1}$ Jorge Ortiz Sotelo, “Captain Davy and the U.S. Naval Mission in Peru, 1920-1930," in William R. Roberts and Jack Sweetman, New Interpretations in Naval History: Selected Papers from the Ninth Naval History Symposium held at the United States Naval Academy, 18-20 October 1989 (Annapolis: Naval Institute Press, 1991), 64. Ortiz concludes that "A close and firm relationship between the United States and Peruvian navies was established" during the U.S. naval mission's years in Peru, a friendship that "reached its peak during the 1950s and 1960s," when the Peruvian navy was commanded by officers who graduated from the Escuela Naval during the 1920s.
} 
The U.S. naval mission's major accomplishments in Peru during this period fell into three broad areas: the creation of a rigorous system of naval education, the establishment of a submarine force as the foundation of Peru's naval defenses, and the formation of a national aviation system. Each afforded naval mission personnel opportunities to share knowledge and practices in areas of recent innovation within the U.S. Navy, and more broadly, each clearly supported the goals Leguía had for both naval reform and national development. As it worked to bring about changes in these areas, though, the mission's broad executive powers did help open a fissure within the Peruvian Navy's officer corps between younger, more junior officers who favored the mission and saw its work as essential to Peru's naval future, and older, established officers who resented the intrusion of U.S. officers into their ranks and viewed the mission's broad authority over the Peruvian Navy as a subversion of the nation's sovereignty. Leguía's repressive methods, including his liberal use of political imprisonment and exile, helped contain much of the senior-level opposition within the Navy for most of the Oncenio. Moreover, they opened paths of advancement to junior-level officers who embraced the U.S. naval mission's presence in Peru. These officers' progression through the ranks did much to cement a positive long-term relationship between the U.S. and Peruvian navies in subsequent decades.

\section{BUILDING A SYSTEM OF NAVAL EDUCATION}

Both the United States and Leguía viewed the creation of a rigorous system of naval education for junior officers as the foundation for a meaningful, long-term modernization of the Peruvian Navy. Early in the mission's tenure this meant devoting considerable attention to the reform of Peru's Escuela Naval (naval academy) at La Punta, whose directorship was deemed the mission's most important detail. In order to successfully plant the seed of U.S.- 
style naval reform, one member of the mission wrote, it "would be necessary to start with the youth of the country" and build long-term support for change within the Peruvian Navy's officer corps. ${ }^{2}$ The reform program put into effect by the officer assigned to lead the Escuela Naval, Charles Gordon Davy (Commander, U.S. Navy, who held the rank of Capitán de Navio in the Peruvian Navy) reflected this goal of using the academy as a seedbed for longterm institutional change. Upon assuming the directorship on February 9, 1921, Davy outlined a reform program focused on improving the academy's academic quality, instilling a focus on naval professionalism, ensuring that the school's cadetes navales gained significant experience at sea.

The challenges confronting Davy's reform vision were significant. In a dispatch to the Office of Naval Intelligence (ONI, which oversaw the mission's activities in Peru) near the end of his first academic year at the Escuela Naval's helm, Davy reported having found the academy in deplorable condition. "Influence" outweighed merit in the cadet admissions process; textbooks were scarce and outdated; examinations emphasized rote memorization over comprehension; discipline was "lax" and poorly administered; at-sea training for cadets was non-existent; and perhaps of greatest concern to the proud Annapolis graduate, there was "little of the military or naval in the atmosphere" around the school. ${ }^{3}$ Davy immediately sought and received from President Leguía both the authority to dissolve the numerous boards and committees that had previously governed the academy's rules and regulations,

\footnotetext{
${ }^{2}$ See "Brief Summary," 3, as well as Commander Lewis D. Causey to ONI ("U.S. Naval Mission to Peru"), RG 80, File 26255-611, Box 1612, National Archives. In his illustrated history of Peru's naval academy, Jorge Ortiz Sotelo has written that the U.S. naval mission detailed one of its members as director of the academy due to a "clear conviction that change and reform in the Peruvian Navy could be consolidated only through its application to the Naval Academy." See Ortíz Sotelo, Escuela Naval del Perú: Historia Ilustrada, 89.

${ }^{3}$ See Memorandum from C.G. Davy to Office of Naval Intelligence (entitled "Condition in which the Academy was Found" and "Progress Made"), December 1, 1921, RG 38, Office of Naval Intelligence, File E-9-b, Box 755, National Archives. Hereafter, cited as "Condition."
} 
and the power to promulgate new standards "as he deemed advisable" for the academy's future administration. ${ }^{4}$ The subsequent re-writing of the academy's rules and regulations required an immediate two-month postponement of the start of the first academic year under U.S. leadership, and resulted in a complete restructuring of the academy's executive and academic departments such that they "closely resemble[d]" those of the U.S. Naval Academy at Annapolis, Maryland. ${ }^{5}$ Under the new structure, an executive officer responsible to the academy's director would supervise the company-sized student body's day-to-day military activities and administer discipline, while reorganized academic departments would govern a new curriculum that ranged from naval engineering and navigation to mathematics, foreign languages, the sciences, literature, and history. Such a structure was necessary, Davy concluded, in order for the school to meet its mission of "giving the state young men whose physical, mental, and moral aptitudes enable them to be officers in the first line of defense of the fatherland: the Navy."

Davy's highest reform priorities as Director were, as his initial restructuring of the academy suggests, strengthening the school's academic program and fostering a culture of naval professionalism. Reforming the academy's curriculum in accordance with U.S. norms required, first, a substantial departure from the lecture-based learning model that had long been dominant. It was a model, he wrote, in which course instruction proceeded from "rigid outlines" while cadets' workloads consisted principally of absorbing instructors' in-class

\footnotetext{
${ }^{4}$ Commander Lewis D. Causey, Report on “U.S. Naval Mission to Peru," RG 80, File 26255-611, Box 1612, National Archives, 3.

5 See "Condition," 4.

${ }^{6}$ Ortíz Sotelo, Escuela Naval del Perú: Historia Ilustrada, 91-92.
} 
lectures. ${ }^{7}$ Davy instituted what he called "practically a reversal" of the lecture-based model, one that required "more work" and "more application" from cadets and lightened the lecture burden on instructors. To carry this reform to fruition, the academy would have to be stocked with sufficient numbers of "modern" Spanish-language textbooks spanning the entirety of the curriculum. It was a burden that Davy took up personally, translating a number of U.S. Naval Academy and U.S. Naval Institute texts covering naval engineering, mathematics, and the sciences.

Essential to improving the academy's academic quality for the long-term was shoring up both the cadet admissions process and cadet retention standards. Nominally governed by merit, in practice the academy's admissions process had long been "afflicted with certain defects," noted the professional journal of the Peruvian Navy, the Revista de Marina (which Davy edited), in its November-December 1921 issue. Too often, new cadets were admitted solely on the strength of the colegio (high school) diplomas they presented, the Revista concluded, a method Davy believed did not take adequate stock of the entirety of prospective cadets' skills and aptitude. Not giving admissions authorities a view of the whole person, he maintained, left room for influence peddling in the admissions process and permitted too many "poorly prepared" candidates into the academy who had "no serious intention of ever making the Navy their profession." ${ }^{\prime 8}$ To address the problem, he refocused admissions on clear physical standards and on the results of an annual competitive examination designed to test academic aptitude. Candidates who met basic physical requirements would compete for

\footnotetext{
${ }^{7}$ In his December 1, 1921 report to ONI, Davy wrote that on a day-to-day basis the lecture model of learning previously employed at the academy meant that cadets engaged in "much laborious copying in notebooks" and little if any reading of textbooks. See "Condition," 1, 5.

8 "Exposición de reformas en nuestra Escuela Naval," Revista de Marina VI, no. 4 (Noviembre-Diciembre 1921): 466. For Davy's assessment, see "Condition," 1.
} 
a set number of spots in the entering class through an examination covering mathematics (arithmetic, algebra, and geometry), as well as grammar, geography, and history. Following that, candidates would be subjected to an assessment of their overall "presence" by an admissions board that would score candidates' education, general demeanor, and overall potential to become good naval officers. ${ }^{9}$ To ensure that the academy drew the best qualified candidates from the widest possible pool, and to overcome what Davy saw as the very real problem of having a student body drawn excessively from the local area of Lima and its port, Callao (which, in his view, undermined the Navy's claim to be a truly national institution), the new admissions policy also aimed to ensure geographical diversity. Under rules he established, in situations where multiple candidates hailed from the same Department or Constitutional Province of the country, admission would be granted to the candidate with the highest merit as established through the revamped competitive examination process. ${ }^{10}$

As he moved to strengthen the admissions process, Davy also sought to address the academy's problem of retaining large numbers of academically deficient cadets from one year to the next. For example, in his December 1, 1921 report to ONI, Davy noted that more than $90 \%$ of the 1920 entering class (the last full class to matriculate before his arrival) finished its first year academically deficient in one or more subjects. To ensure such laxity did not continue, he approved three new measures aimed at raising academic standards: the first raised the bar for "academic sufficiency" from $55 \%$ to $60 \%$ on graded work (the national standard in Peru was 50\%); the second required the expulsion or "turning back" of

\footnotetext{
9 “Exposición de reformas en nuestra Escuela Naval," Revista de Marina VI, no. 4 (Noviembre-Diciembre 1921): 468 .

${ }^{10}$ Ibid, 467. Also, Davy noted in his December 1, 1921 report to ONI that one of the many weaknesses of the competitive examination process prior to his arrival was that it was "never announced until a week or two before they [the examinations] were to take place. It resulted that nearly all the candidates came from Lima or Callao and did not represent the country as a whole. The ready accessibility of their homes was a bad influence on serious work." See "Condition," 2.
} 
academically deficient cadets on an annual basis; and the third extended the academic year from ten to eleven months. ${ }^{11}$ These policies took rapid effect. During the first year of Davy's directorship, 26 of the 71 cadets who had completed the 1920 academic year were dropped from the academy altogether while another 30 were forced to repeat various classes in order to retain their positions at the academy. Combined with the fact that only 17 new cadets gained admission through the first competitive entrance exam administered on Davy's watch, for the academic year beginning on May 1, 1921, the result was a student body for the school's first year under U.S. direction of only 62 cadets - nine fewer than the previous year and well below the optimum level of 80 that Davy thought necessary in order to keep the Navy adequately supplied with junior officers in the future. Confident, however, that higher quality was more important than quantity, he reported happily at the end of that year that the academy's new admissions and academic standards had had a "magical effect": cadets carried a larger workload and performed better, fewer were deemed academically deficient, and faculty morale had improved. ${ }^{12}$

More rigorous academic standards supported Davy's efforts to foster a culture of professionalism at the academy. Instilling professionalism began, Davy insisted, with strengthening the ties that bound the academy and its cadets to the Peruvian Navy. Upon assuming the directorship he had complained that the academy had more the atmosphere of a civilian university than a military institution. As a whole, he wrote, it "lacked a good many of the fundamental principles of a military school." Under the previous director, cadets were

\footnotetext{
${ }^{11}$ See "Condition," 1, 4.

${ }^{12}$ See "Condition," 5.
} 
free to consider themselves "as boys at school and not as part of the Navy." 13 Davy therefore took several early steps to bring the academy firmly within the Navy's control. First, he established a requirement that new cadets entering the academy take an oath similar to the one taken by new midshipman at the U.S. Naval Academy, a measure intended to reinforce the message that, by entering the academy, cadets were entering naval service. Moreover, it would enforce that commitment by exacting a promise from new cadets to remain in the Navy for five years after graduation. ${ }^{14}$ Second, he secured the dissolution of the academy's disciplinary board and reserved for himself, as director, the power to administer cadet discipline - a power he called "one of the fundamental functions of command," and one that he had lacked upon assuming the directorship. Employing this power, Davy went after what he considered one of the most damaging holes in the academy's system of discipline by doing away with weekend leaves that had previously been so liberally distributed that, more often than not, a majority of cadets slept off academy grounds on Saturday nights. This was a problem in practice, he reported to ONI, because so many cadets hailed from the local Lima-Callao area, and because many routinely extended their weekend visits into Monday morning (cutting into the academic and training week) without prior authorization and without real fear of consequence from the academy's disciplinary board. This ready access to the comforts of family life for one day every week "effectively 'undid' any good work of military development of the week," Davy argued, and contributed mightily to the lax civilian atmosphere which Davy saw permeating the institution. It nurtured a harmful perception that cadets "still belonged to their fathers and mothers and not to the State," he wrote, and more

\footnotetext{
${ }^{13}$ See "Condition," 3, and Commander Lewis D. Causey to ONI (“U.S. Naval Mission to Peru"), RG 80, File 26255-611, Box 1612, National Archives.

${ }^{14}$ Under the regulations of the previous academy administration, cadets only had to take an oath of postgraduation service at the beginning of the second year. See "Condition," 3.
} 
significantly, helped widen the chasm he saw separating the academy from the Navy it existed to serve. ${ }^{15}$

Davy pursued other reforms in attempt to break those bonds of familial dependency and replace them with a strong ethic of naval professionalism that bound cadets to the academy, to the Peruvian Navy, and by extension, to the Peruvian state. Central to this, he believed, was ensuring that the academy could provide for the physical and material needs of cadets during their academy tenures, a particularly significant challenge in light of the status quo prior to the U.S. naval mission's arrival in Peru in 1920. Under its previous administration, owing to scarce resources, the academy had maintained a policy that required entering cadets to provide for their own uniforms, personal equipment, and to meet their own food costs during the first year of studies - the idea being that the government would assume responsibility for those costs in subsequent years. In practice, however, many second, third, and fourth-year cadets were also left to provide for themselves because, as Davy wrote, provisions purchased by scarce government appropriations were often distributed among upperclassmen according to "whose families or friends could muster the required influence" to secure them. This weakened the link between the academy and the Navy it served, Davy argued, and created an economic inequality among cadets of an unhealthy and "most pernicious condition" that endangered the school's ability to meet its mission of producing naval officers for the state. ${ }^{16}$ Given Davy's desire to differentiate the academy from Peru's civilian universities as well as his insistence on drawing cadets fully into the nation's naval service, he deemed it essential that the national government shoulder the burden of supplying all necessities cadets required throughout their academy educations. Near the end of his first

\footnotetext{
${ }^{15}$ See "Condition," 3.

${ }^{16}$ See "Condition," 3.
} 
year at the helm, Davy reported proudly that inequality among cadets was shrinking due not to a massive infusion of funds, but to a "democratic" rationing of supplies by academy officials. Moreover, he noted that although a shortage in funds had kept the policy from going into effect, new academy regulations called for each cadet to receive an annual allowance of 40 Peruvian Pounds for the purchase of academic and military supplies "essentially naval in character.",17

Developing naval professionalism at the academy required more than meeting cadets' material needs, however; it required strengthening the bonds of service among cadets, between cadets and the academy, and between the academy and the Navy. An article in the March-April 1924 issue of the Revista de Marina explained the importance of these linkages to an effective naval service and a sound national defense. Written by a U.S. naval officer, translated into Spanish, and republished from the Proceedings of the U.S. Naval Institute, the article (entitled "El Servicio Naval," or "The Naval Service") argued that the overall quality and efficiency of a nation's Navy was derived principally from the "espíritu de cuerpo" (esprit de corps) among its officers, which could not be developed through rules, regulations, or decrees, but had to "come of its own accord through love of the service." Love of service took firm root, the author suggested, in officers' aspirations to serve the whole nation in an institution (the Navy) that "belongs to the people of the country" and is wholly dependent on its people both for annual appropriations and for necessary "moral support." In an incisive passage which echoed the role Leguía envisaged the Peruvian Navy playing in the socioeconomic life of Peru, the author further noted that, no matter how small or seemingly unimportant, every action a naval officer took in the service of the nation contributed to

\footnotetext{
${ }^{17}$ See "Condition," 5.
} 
country's security and "protect[ed] its future development." A healthy naval service infused with sufficient esprit de corps was thus integral to the life, security, and prosperity of the nation as a whole. As the Escuela Naval was in Davy's view, in the author's view the naval academy was a place where the seeds of effective esprit de corps - abiding friendship, brotherhood, and fealty to naval service - could take root and grow. ${ }^{18}$

In an effort to shape an environment conducive to the growth of an esprit de corps, Davy instituted placed heavy emphasis on team sports and athletic competitions, and adapted a number of traditions in effect at the U.S. Naval Academy at Annapolis, Maryland. And to strengthen cadets' ties to each other and to the academy, Davy presided over the incorporation of traditions similar to many in effect at the U.S. Naval Academy. Among the most symbolically important of these was the adoption of the tradition of the class ring featuring the academy seal on top, and years of matriculation and graduation on the sides. Embraced for the first time by the Escuela Naval's class of 1925, as the Revista noted, the class ring would serve as a physical reminder of cadets' experiences at the academy as well as their bonds to one another and to the institution. Moreover, it would become "a symbol of union and strong fellowship" among those who wore it. ${ }^{19}$ The adoption of a class ring tradition followed closely on the heels of the establishment the year before of the "Class of 1924 Association," formed by that year's graduating class for the purpose of maintaining "that spirit of comradeship that should be traditional among all who graduated from the

\footnotetext{
${ }^{18}$ H.H. Frost, "El Servicio Naval," Revista de Marina IX, no. 2 (Marzo-Abril 1924): 123-135. Original article is H.H. Frost, "The Naval Service," Proceedings of the U.S. Naval Institute 50, no. 1 (January 1924): 31-39.

19 “Anillo de Promoción,” Revista de Marina X, no. 6 (Noviembre y Diciembre, 1925): 825-826.
} 
Peruvian Naval Academy and, at the same time, to keep the highest ideals of honor, honesty, truth, self-denial and enthusiasm for the institution." ${ }^{20}$

While making efforts to forge a lasting spirit of comradeship among cadets, Davy sought to focus the academy squarely on its mission of supporting the Navy, and on the Navy's mission of defending the nation. To this end, under his leadership the academy adopted as its motto "Mihi Cura Futuri," translated from Latin by a cadete navale in a 1922 essay as meaning "to me is entrusted the future." ${ }^{21}$ In practice, this cadet wrote, the motto drew a clear and unmistakable link between cadets' academy experience and the subsequent naval service all were required to render:

"I study to develop my intelligence; I awaken my spirit to strengthen my character; I educate my muscles to increase my physical strength, so that tomorrow, when I carry the noble title of naval officer, I can transfer this knowledge - this moral, intellectual, and physical strength - to sailors whose instruction or preparation is entrusted to me, thus forming in them the knowledge and character without which it is impossible to dream of a powerful navy."22

Intended to reinforce to cadets that the academic, physical, and moral challenges they confronted during their academy educations were preparation for future naval service, "Mihi Cura Futuri" was also intended to instill in them an appreciation for the Peruvian Navy's reason for being: to prepare for and fight the nation's wars. Cadets therefore had to prepare on the assumption that war was an "inevitable" eventuality: modern war represented a "struggle of minds," and as such, the "national energies" required to fight it had to be developed and matured over time and could not be the "fruits of an instant." It was only at the Escuela Naval, this cadet concluded, that minds and spirits of Peru's young men could be

\footnotetext{
${ }^{20}$ Ortíz Sotelo, "Captain Davy and the U.S. Naval Mission in Peru, 1920-1930," 61.

${ }^{21}$ Cadete Carlos Adolfo de la Jara, "Importancia de la divisa 'Mihi Cura Futuri' adoptada por la Escuela Naval del Perú," Revista de Marina VII, no. 6 (Noviembre y Diciembre, 1922): 766.

${ }^{22}$ Ibid, 766-767.
} 
molded into those of officers capable of defending the nation. For cadetes navales, then, "Mihi Cura Futuri" was far from a meaningless generality. It was a concise expression of Davy's vision of the Escuela Naval as an integral part of Peru's naval service. As the cadet essayist concluded, its unmistakable meaning was that in preparing for the future, "Yo me preparo para la guerra" (I prepare myself for war). ${ }^{23}$

To strengthen this institutional focus, and to ensure that Peru's cadetes navales received an "appropriate balance of theory and practice" in preparation for the rigors of naval officership, Davy moved to require all cadets to participate in at-sea training early and often during their academy educations. Upon his arrival he had identified the lack of sea training as a significant flaw in the academy's overall training program, noting that throughout their entire four-year academy experience cadets "never enjoyed the advantages of service on board ship" until they received their appointments as midshipmen following graduation. ${ }^{24}$ Together with his plans to reform the academy's academic program, remedying this deficiency required a complete restructuring of the whole institution's yearly calendar consistent with Davy's promise that, on his watch, the academy would work "twelve months a year and thirty days a month." 25 Months after taking charge of the academy, he approved a new schedule that compressed the academic year from two five-month sessions into one eight-month period (from early May through December), reduced cadet vacation from two one-month periods to one (April), and established a full three-month period for sea training during the summer months of January, February, and March. ${ }^{26}$ Indeed before Davy even

\footnotetext{
${ }^{23}$ Ibid, 771-773.

${ }^{24}$ See "Condition," 1.

${ }^{25}$ Quote from Ortíz Sotelo, "Captain Davy and the U.S. Naval Mission in Peru, 1920-1930," 60.

${ }^{26}$ See "Condition," 4.
} 
welcomed the first entering class of his tenure, in March of 1921, he dispatched the academy's fifty-six upper class cadets (none of whom had any experience serving on board a naval vessel) on a training cruise of the Peruvian coast north and south of Lima aboard the Almirante Grau and Coronel Bolognesi in order to expose them to service at sea, acquaint them first-hand with the nation's coastline, and as a "reciprocal function" permit the people of Peru's port cities to become familiar with the Navy. ${ }^{27}$

Deemed a success by Peruvian and U.S. personnel in 1921, in subsequent years the crucero de verano (summer cruise) became a mainstay of the academy program and a cornerstone of the broader Navy's annual training agenda. As an indication of both the growing strength of the Peruvian Navy and the increasingly close naval, political, and economic ties developing between the Leguía government and the United States, in 1925 the annual cruise ventured for the first time far from Peruvian shores - to the American naval base at Balboa, at the Pacific end of the Panama Canal. In Panama, Peruvian ships transited the Canal and cadets visited U.S. submarine base at Coco Solo while the Almirante Grau received repairs at U.S. naval facilities. A similarly ambitious itinerary characterized the 1926 cruise, which was the first to incorporate two new submarines Peru had recently acquired from the Electric Boat Company of Groton, Connecticut. And, in a reflection of just how close the ties were growing between the academy and the Peruvian Navy, between 1927 and 1930 the geographical scope and substantive complexity of the crucero de verano grew even further: Peruvian cadets visited ports in Colombia, Costa Rica, Nicaragua, Honduras, El Salvador and Chile (in addition to Panama), and learned firsthand how Peru's surface vessels were beginning operate in tandem with Peru's newest naval assets -

\footnotetext{
${ }^{27}$ Ortíz Sotelo, Escuela Naval del Perú: Historia Ilustrada, 98.
} 
submarines and naval aircraft. ${ }^{28}$ Indeed, thanks in large measure to Davy's leadership, by the late 1920s the Escuela Naval had become a bastion of naval professionalism and an integral part of the Navy it existed to serve. Moreover, during the time of the U.S. naval mission, it molded the generation of officers who, for decades to follow, would look favorably on the United States and effect a long-term closeness between the Peruvian and United States navies.

\section{ESTABLISHING A MODERN SUBMARINE FORCE}

The Navy became the linchpin of Peruvian national defense under Leguía, who saw unresolved tensions with Chile as Peru's most pressing foreign policy concern. Recalling the War of the Pacific (1879-1883), he saw Peru's coastline as its greatest security vulnerability. ${ }^{29}$ In the decades following that costly war, Chile had maintained a significant military superiority over Peru, the backbone of which was a pronounced naval advantage that successive Peruvian governments in the late 19th and early 20th centuries proved unable to overcome. $^{30}$ Leguía saw in the relatively new and rapidly advancing technology of submarines the potential for Peru to achieve significant advances in its coastal defense capabilities without going to the expense of a major expansion of its surface fleet. In his view, submarines' ability to move stealthily while submerged meant cash-strapped Peru could acquire more national security from a relatively smaller number of submarines than it

\footnotetext{
${ }^{28}$ Ibid., 99-101.

${ }^{29}$ Overland invasion from Chile into Peru proved virtually impossible during the War of the Pacific, as both the Andes mountains and the vast Atacama desert made long-distance ground operations exceedingly difficult. Hence, when the Chilean army finally invaded Peruvian territory and took the capital of Lima, they arrived on Peruvian soil via the sea. See Sater, Andean Tragedy: Fighting the War of the Pacific, 1879-1884, 258-300.

${ }^{30}$ Robert Scheina notes that in the late 19th and early 20th centuries the Chilean navy, "Peru's most serious potential opponent, was overwhelmingly superior, and given the resources available there was no way possible for the Peruvian fleet to match its strength.” Scheina, Latin America: A Naval History, 1810-1987, 130.
} 
could by purchasing a comparable number of new, more expensive surface ships. This meant that even though Peru could not afford to build or buy its way to numerical parity with the Chilean Navy, it could substantially narrow the overall capability gap with Chile without breaking the bank. Thus did Leguía make the acquisition of submarines the centerpiece of his plans for building Peru's naval strength upon assuming the presidency for the second time in early July of 1919.

This initiative to establish a modern submarine force in the 1920s represented a continuation of efforts Leguía had made earlier, during his first presidential term (19081912), when the Peruvian Navy was for a time under the tutelage of a small French naval mission, and when border disputes with each of Peru's neighbors - including one with Ecuador that nearly led to war in 1911 - made strengthening the nation's defenses a central concern. ${ }^{31}$ Seeking a budget-friendly way to quickly boost the capability of Peru's coastal defenses, during that period Leguía had accepted the French naval mission's recommendation to enact a modest, defensively-minded naval expansion program that emphasized the acquisition of "small unit" assets such as torpedo boats and submarines. As Jorge Ortiz Sotelo notes, such assets were capable of high speeds and possessed low surface profiles that would significantly improve the Peruvian Navy's ability to challenge enemy capital ships along Peru's coast. ${ }^{32}$ Moreover, as a commission of Peruvian naval officers concluded in endorsing the purchase of two French submarines in 1910, Peru's limited fiscal resources made submarines the only immediately viable option for counteracting the superior

\footnotetext{
${ }^{31}$ The Peruvian army had hosted a French military (army) mission since 1896, and as Robert Scheina notes, once the decision was made to contract a naval mission, the officers of the French military mission no doubt influenced the selection process. Moreover, he notes, a French mission made sense for Peru at the time because rival Chile had longstanding naval ties to Great Britain and already hosted a British naval mission, while the United States had not yet embraced the idea of employing naval officers in such a capacity. Ibid., 130-31.

${ }^{32}$ Ortíz Sotelo, Apuntes Para la Historia de los Submarinos Peruanos, 40.
} 
naval power of potential enemies. In supporting the purchase, the commission noted approvingly the words of former First Lord of the British Admiralty George Goschen, who in 1900 famously characterized the submarine as a "weapon of the weaker nation." For a nation dealing with unsettled border questions, experiencing economic upheaval, and facing a persistent naval inferiority vis-a-vis its historical rival (Chile), the Peruvian Navy of the early twentieth century found hope in Goeschen's admonition that "the nation which possesses it [the submarine] will cease to be weak, and will become really powerful., ${ }^{, 33}$

The service lives of the two submarines Leguía's government purchased from France in 1910, the Ferré and the Palacios, were active but short. Both were decommissioned shortly after the U.S. naval mission arrived to take charge of the Peruvian Navy in 1920, a time when Leguía, eager to deepen Peru's relations with the United States, had already begun looking to replace the French-built boats with a larger number of modern submarines built in the United States. Leguía's strategic rationale for doing so was laid out by his naval attaché to Washington, Luis Aubry, in a May 1920 public address in Lima. The submarine represented an economical way to rapidly boost Peru's coastal defenses, the career officer and submarine advocate argued. He stressed that that the submarine's value had been proven by the fact that "the two most powerful fleets in the world were not able to do anything against it" during the recently concluded "Great War" in Europe, and suggested that Peru was uniquely positioned to benefit from the submarine's acceptance as a weapon of modern war. Echoing themes Leguía had struck while pushing for submarine acquisitions during his first presidential tenure, Aubry argued that given Peru's geographic position, unsettled borders, and especially its unresolved difficulties with Chile, the nation could not stake its

\footnotetext{
${ }^{33}$ Nicholas A. Lambert, Sir John Fisher's Naval Revolution, Studies in Maritime History (Columbia: University
} of South Carolina Press, 1999), 43-45. 
future security on diplomacy alone, but would have to back its foreign policy with credible force. Submarines were the ideal fit for Peru's precarious strategic situation, he continued, because the nation found itself "in a state of incipient military and naval development" relative to its likely enemies - again, Chile foremost among them. Moreover, Peru had "scarce resources" it could devote to strengthening its defenses. A modest fleet expansion whose centerpiece was six submarines, complemented by six destroyers, would solve "eighty percent of the country's vulnerability," he concluded, adding that such a program would constitute "the best insurance policy" for denying potential enemies all-important control of Peruvian coastal waters. ${ }^{34}$ And, considering Peru's greatest vulnerability to invasion lay in its coastline, like Leguía, Aubry saw that submarines would help ensure Peruvian control over the invasion route future aggressors would most likely take into the country. ${ }^{35}$

Leguía's aim of making submarines a cornerstone of Peru's national defense had a substantial impact on both the composition of the U.S. naval mission and the work it undertook upon its arrival. As early as the spring of 1920, when negotiations for a mission were just getting underway, Leguía had informed Washington of his desire to receive officers with expertise in submarine warfare who could serve as instructors for the Peruvian Navy. ${ }^{36}$ This desire was met in the person of Lewis D. Causey (Commander, U.S. Navy), a 1906

\footnotetext{
${ }^{34}$ Luis Aubry, El Torpedero Submarino y la Reciente Guerra Mundial (Washington: National Publishing Co., 1920), 62-63.

${ }^{35}$ When Chilean forces invaded Peru and stormed Lima during the War of the Pacific, they did so from the sea because the prohibitively difficult overland route would have required traversing the Andes mountains as well as the vast Atacama desert.

${ }^{36}$ An Office of Naval Intelligence report noting Chilean reaction to Peru's request for a U.S. naval mission notes that given Peruvian-Chilean tensions, "it is interesting to note that an Act of Congress in June authorized the receiving of a North American Commission to Peru." Quoting an Argentine news report, it continues, "From the 'Army and Navy Register' of Washington it is noted that only officers of practical experience in destroyers, submarines, and mines, are wanted, and these as instructors in those specialties." See Office of Naval Intelligence Report ("PERUVIAN NAVY: Article in the Buenos Aires 'Prensa' quoting the 'Naval and Military Record' of August 18, 1920”), September 22, 1920, RG 38, Office of Naval Intelligence, File E-9-d, Box 761, National Archives.
} 
graduate of the U.S. Naval Academy who had commanded a submarine division in the waters off Ireland and the Azores during World War I, and who had led the U.S. Navy's fledgling submarine school at New London, Connecticut, in the war's waning days. ${ }^{37}$ With these qualifications Causey was given command of the Naval Division (operating fleet) of the Peruvian Navy and the rank of Capitán de Navío. And, as the naval mission's resident submarine expert, he was pressed into service almost immediately to provide Leguía with advice on the shape of Peru's future submarine force.

Clearly favoring the acquisition of American-built vessels, Leguía had delayed two important decisions on submarines until after the American mission's arrival in order to avail himself of its officers' counsel. First he looked to his new Naval Division commander to weigh in on a proposal, which was already before the government, that provided for the purchase of two Italian-built submarines. The proposal had originated with Lima's Asociación Naval Pro-Marina, an organization of naval enthusiasts that had long lobbied the government for a stronger Navy and raised funds for naval acquisitions when government appropriations fell short of desired levels. ${ }^{38}$ Convinced of the utility of submarines following the European war, the Asociación had initiated a fundraising drive early in 1919 - before Leguía's July return to the presidency - to acquire new submarines for the Navy. By early 1920 it had raised enough money to enable the government to contract with the Italian firm Ansaldo San Giorgo for the construction of two 430-ton submarines, and to provide a down payment of two-million Italian lira so construction on those vessels could begin. On

\footnotetext{
${ }^{37}$ Lewis D. Causey biographical profile contained in “Misión Americana," Revista de Marina V, no. 6 (Noviembre y Diciembre, 1920): 732.

${ }^{38}$ Asociación Naval Pro-Marina fundraising had been instrumental in the acquisition of the French-built submarines Ferré and Palacios during Leguía's first term, as well as in the earlier acquisition of the cruisers Almirante Grau and Coronel Bolognesi. See Ortíz Sotelo, Apuntes Para la Historia de los Submarinos Peruanos, 78-79.
} 
Leguía's request, the naval mission examined the deal immediately upon its arrival, before its members were even fully established in their positions in the Peruvian Navy. Not surprisingly given Leguía's inclinations and Commander Causey's desire to remake the Naval Division along U.S. lines, the mission found the Italian submarines' specifications inadequate to the nation's needs, recommended that the contract be terminated, and called for as much of the down payment as possible to be recovered for future use. ${ }^{39}$ Only weeks into its tenure in Lima, the U.S. naval mission was not prepared to lay out a complete set of recommendations on future naval acquisitions, but in voting to kill the Italian submarine deal its members clearly agreed with Leguía that in the future Peru should look to the United States rather than to Europe for such purchases.

The demise of the Italian contract foreshadowed the naval mission's action on the other pressing decision Leguía faced early on regarding the future of Peruvian submarines: what to do with the aging Ferré and Palacios, which had fallen into disrepair. Employed heavily in Peruvian naval exercises during their early years in the fleet (1913-1915), the French-built submarines' operational effectiveness quickly fell victim to the same economic dislocations that affected much of South America following the outbreak of World War I. ${ }^{40}$ Specifically, during the war the Peruvian Navy could not acquire the replacement batteries from France it needed to keep the boats supplied with electrical power while submerged. ${ }^{41}$

\footnotetext{
${ }^{39}$ Ibid., 80. See also Commander Lewis D. Causey to ONI (“U.S. Naval Mission to Peru”), RG 80, File 26255611, Box 1612, National Archives. In that report, Causey writes that "Before the mission had made a complete study of the [Peruvian naval] situation and arrived at a conclusion, due to the controversy over the purchase of some Italian-built submarines, the Senate passed a resolution calling on the Naval Mission to report on the advisability of purchasing these submarines, also what Naval acquisitions the Government should make. The Mission reported against the acquisitions of these submarines, but did not report until a later date on acquisitions."

${ }^{40}$ Tulchin, The Aftermath of War: World War I and U.S. Policy Toward Latin America, 3-37.

${ }^{41}$ Robert Scheina notes that the Ferré and Palacios were used so heavily after 1913 that "the loss of torpedoes during practice proved to be an expensive problem." See Scheina, Latin America: A Naval History, 1810-1987,
} 
Incapacitated by a lack of adequate power, the vessels were therefore in a highly vulnerable position by the time a commission, chaired by Commander Causey, was appointed in April of 1921 to assess their military value and determine their service fates. In short order Causey's commission found that the submarines' condition was so far gone that the "the cost of making them...of any military value was so great that it was inadvisable to undertake the job." The commission recommended that "due to their age and obsolete type," the Ferré and Palacios be decommissioned, dismantled, and that the materials in them be reused in the construction of a future submarine base on San Lorenzo Island adjacent to the port of Callao." ${ }^{42}$ These recommendations, which helped clear the way for future purchases of U.S. vessels, were entirely consistent with Causey's broader assessment of the rest of the Peruvian fleet. In general, he found, Peru's surface fleet was similarly outdated and in poor condition: all of the Navy's surface vessels were considerably older than the two French-built submarines and, with only one exception, he wrote, "had had no overhaul of any extent" for a number of years. ${ }^{43}$

By the time he reported to Leguía on the Naval Division's condition in mid-1921, it was clear to Causey that the entire Peruvian fleet would require a substantial updating and overhaul, and that Peru would have to acquire new surface vessels and submarines in order to adequately defend its lengthy coastline. In the near-term, however, the country's poor fiscal outlook precluded even a modest acquisition program focused on the kinds of defensive arms

131. Also, Jorge Ortiz Sotelo notes that the battery issue was a pressing problem because the French-built submarines were dependent on battery power for submerged operations, and because the batteries installed during construction had a five-year life expectancy See also Ortíz Sotelo, Apuntes Para la Historia de los Submarinos Peruanos, 61.

${ }^{42}$ Ibid, 64.

${ }^{43}$ Commander Lewis D. Causey to ONI (“U.S. Naval Mission to Peru”), RG 80, File 26255-611, Box 1612, National Archives. 
(submarines, airplanes, and "a destroyer or two") he believed were essential to ensuring Peru's future security. ${ }^{44}$ Importantly for Leguía's naval ambitions, even as mission members recognized Peru's immediate fiscal troubles, they assumed that eventually the United States would step in to help. Even though "the money for the purchase of any of these acquisitions is not absolutely available," Causey wrote, the plan "was to proceed with the idea in view of making money available" in the United States for Peru's naval purchases. Together with the scuttling of the Italian submarine deal the previous year, then, the decommissioning of Peru's two French-built submarines before they could be plausibly replaced signaled that although the time for substantial naval acquisitions had not yet arrived, the U.S. naval mission was paving the way for that eventuality by doing away with vestiges of European naval influence.

The cause of the submarine in the Peruvian Navy received a considerable boost with the arrival of Clark H. Woodward (Captain, U.S. Navy) as new head of the naval mission and Chief of the Peruvian General Staff in July $1923 .{ }^{45}$ Within four months of his arrival, Woodward, whose rank in the Peruvian Navy had been elevated by Leguía to Contraalmirante (Rear Admiral), articulated an overarching strategy for Peru's national defense that formalized the Navy's status as the unequivocal guarantor of the nation's security, and laid out a far-reaching naval program emphasizing the need to acquire modern submarines from the United States. He arrived at this conclusion by identifying Peru's strategic predicament even more closely with its geographical reality and its longstanding Chilean troubles than his predecessor had. Peruvian geography dictated that the country's

\footnotetext{
${ }^{44}$ Causey wrote that "Due to the limited finances of the country, the Mission could only recommend small and less costly acquisitions, the exact number I do not remember, but the general idea was to concentrate on aeroplanes, submarines, and a destroyer or two. Ibid, 6 .

45 "Nuevo Jefe Estado Mayor General de Marina," Revista de Marina VIII, no. 4 (Julio y Augusto, 1923): 505508. See also "Brief Summary," 5.
} 
"correct" strategy for national defense was "essentially naval," Woodward wrote, because its nearly 1,500-mile coastline was both its greatest economic asset and its greatest strategic vulnerability. Peru's "impossible mountains" and coastal deserts "force her to look to the sea for communications," he argued, and the natural obstacles that divided its distinct coastal, mountainous, and Amazonian regions meant that Peru's flows of international and domestic commerce were wholly dependent on the sea. This dependency on sea communications was so great, Woodward continued, that the government could not even concentrate its army in any part of the country "without recourse to the sea." The greatest challenge to Peruvian national security, then, was the fact that successive Peruvian governments had consistently failed to maintain naval defenses capable of securing the nation's territorial waters from the threat of enemy attack. The disastrous results of the War of the Pacific, in which Chile landed its Army on Peruvian soil from the sea, had clearly demonstrated the grave consequences that attended naval ill-preparedness. ${ }^{46}$

In the new Chief of the General Staff's view, Peru's "first defense" therefore had to be made at sea, and while securing "command of the sea" had to be the Navy's ultimate goal, at a minimum his proposal for naval acquisitions argued that Peru should strive to be able to deny such command to Chile. Again he pointed for reference to the War of the Pacific, recognizing that "although Chile possessed a superior Navy [during the war], it dared not try to disembark an army on Peruvian soil until the last Peruvian ship was sunk.” Moreover, Woodward argued, even though Peruvian ground forces fought valiantly against the subsequent Chilean ground invasion, it was the Peruvian Navy's defeat at sea that made an

\footnotetext{
${ }^{46}$ Clark H. Woodward, "The Strategy and Naval Policy of Peru,", "Clark H. Woodward Papers (Collection 297), Box 2, Operational Archives, Naval History and Heritage Command, Washington, DC.
} 
invasion possible. ${ }^{47}$ With the current state of the Navy in late 1923, Woodward's assessment of the situation concluded, Peru was "absolutely indefensible by sea." Should Chile or another potential enemy attempt another invasion of Peruvian territory, the ships of Peru's existing fleet would be "completely useless" in preventing or even hindering it "no matter how weak the enemy force employed in the attack." ${ }^{, 48}$

Woodward stressed that the time for Peru to build a modern submarine force was therefore at hand. Recognizing that a significant buildup of the Navy might be politically difficult to undertake absent some immediate national catastrophe, and taking stock of Peru's limited fiscal means, he dismissed as impractical any notion of building an offensivelyminded Navy and instead recommended an "adequate defense" that would - "like firefighters and police forces in a city" - be capable of responding effectively to emergencies and, in his words, nothing more. Woodward stressed that in Peruvian history "the clouds of war have sometimes appeared quickly and the storm has erupted without warning," a reality that made it extremely difficult to prepare for war once it was underway. Failing to plan ahead entailed "enormously high costs not only in money, material, and time, but what is more painful, in human lives." ${ }^{49}$ In its current state, he continued, the Peruvian Navy was powerless to resist the pressure an enemy navy would no doubt apply in its littoral - the lifeline on which the coastal nation's security and economic well-being depended. ${ }^{50}$ The costs of inaction were

\footnotetext{
${ }^{47}$ Clark H. Woodward, "Estudio Sobre El Plan Naval del Peru, 1924," Clark H. Woodward Papers (Collection 297), Box 2, Operational Archives, Naval History and Heritage Command, Washington, DC. This is a twentypage study, written in Spanish on Peruvian "Estado Mayor General" (General Staff) letterhead.

${ }^{48}$ Ibid, 2.

${ }^{49}$ Ibid, 4.

${ }^{50}$ In his earlier assessment of Peru's naval policy and strategy, Woodward wrote that "In case of a future war Peru would be practically wholly dependent upon outside resources, by the highway of the sea, for her materials of war and for many other elements necessary to her life as a people and nation. With an invader in command of the sea the strangulation of Peru would commence and continue to its inevitable consequence, just as it has always happened in like circumstances throughout the world. See Clark H. Woodward, "The Strategy and
} 
therefore, in Woodward's view, unacceptably high. But should Peru decide to undertake even the modest preparations that "responsible" nationhood required, including construction of "a sufficient number of submarines with which to successfully attack the enemy's fleet," he argued, the effort would in all likelihood compel the enemy to abandon or significantly change both its war plans and the assumption of Peruvian naval weakness on which those plans would certainly be based. ${ }^{51}$

Woodward's proposal was forceful not just because it made the acquisition of submarines a priority, then, but because it spoke clearly about the advantages they offered to nations able to devote few resources to national defense. Submarines would not only be capable of harassing enemy vessels that approached the Peruvian coast with little fear of being harmed in the process, he wrote, but could also mount attacks on enemy merchant ships, surface combatants, and troop transports that an enemy might bring to bear in attempting an invasion. Moreover, submarines' range and relative freedom from observation by enemy surface ships (sonar technology had not yet been fully developed) meant that they could operate independently and effectively against enemy naval forces not only in Peru's territorial waters, but in moderately distant enemy waters as well. This, Woodward argued, meant that in the event of war, submarines could observe and inform on enemy ship movements before an enemy fleet reached Peruvian waters, and could do so without significant fear of being discovered by enemy scouting vessels. ${ }^{52}$ But perhaps the greatest

\footnotetext{
Naval Policy of Peru,", , Clark H. Woodward Papers (Collection 297), Box 2, Operational Archives, Naval History and Heritage Command, Washington, DC.

${ }^{51}$ Clark H. Woodward, "Estudio Sobre El Plan Naval del Peru, 1924," Clark H. Woodward Papers (Collection 297), Box 2, Operational Archives, Naval History and Heritage Command, Washington, DC, 5.

${ }^{52}$ On the issue of range, Woodward noted that "as Peru is obligated to assume defense of all of its coast, and in view of the fact that the principal mission of submarines, those that Peru possesses should have a large radius of operation and be of the greatest possible speed both on the surface and while submerged." Ibid, 8 .
} 
benefit submarine operations afforded Peru, he suggested, was that they gave the nation a measure of naval power out of proportion to both the tonnage of its fleet and the funds in its treasury: "the best defenses against submarines are constant vigilance and high speed, conditions that cause excessive fatigue on [the enemy's] personnel and significant strain on materiel," he noted. This meant that "the constant threat of [Peruvian] submarines in proximity decays an enemy fleet to the point that...it will be so exhausted that his defeat may become an easy matter."53 Moreover, Peru's possession of a credible submarine force would compel an enemy fleet to divert resources and attention to the protection of its own ships, hampering the effectiveness of enemy offensive operations and decreasing the threat to Peru's coastal security.

The acquisition program Woodward recommended on these grounds was ambitious and costly. Its centerpiece was the purchase of six U.S.-built R-Type submarines, but it also included a call for six U.S.-built destroyers, twenty-five naval aircraft, and large numbers of torpedoes, mines, depth charges, and shells as well as the construction of a new submarine base on San Lorenzo Island and a number of other naval building projects ashore. The hefty bill for this naval overhaul, more than six million Peruvian Pounds, would be paid using loans secured from U.S. banks. The loans would be repaid over time using the proceeds of a new national defense tax proposed by Leguía, while the initial "down payment" needed to get ship construction underway (approximately 170,000 Peruvian Pounds) would come from the reliable coffers of the Asociación Naval Pro-Marina. ${ }^{54}$

Although expensive, Woodward's late 1923 proposal was not as fiscally impractical as it would have been had his predecessor proposed it even one or two years earlier. That is

\footnotetext{
${ }^{53}$ Ibid, 8-9.

${ }^{54}$ Ibid, 14-15.
} 
because American lenders' confidence in Peru had begun to grow by late 1923 in response to increased U.S. influence over Peru's national finances. As noted in Chapter 1, the first significant loan that Leguía's government secured from a New York bank, in 1921, had come with the condition that he appoint an American citizen, economist William W. Cumberland, as administrator of Peruvian customs. Once in place, Cumberland's charge quickly expanded to include advising Leguía on the national budget and serving as a member of the board of directors of the newly established, U.S.-designed Reserve Bank of Peru. ${ }^{55}$ With these closer financial ties to the United States, what followed was a period of greater fiscal stability and economic growth - if also greater indebtedness - within Peru. ${ }^{56}$ Between 1924 and 1928, more than ten times the amount of foreign capital entered Peru than had come in during the 1919-1923 period, and as Barbara Stallings notes, the increasing enthusiasm of American bankers for investments in Peru during these years meant that Leguía no longer had to "cajole" them or threaten to seek loans in Europe, while the U.S. State Department no longer had to "intervene to encourage the [American] banks to lend" to support its ally, Leguía, in Peru. ${ }^{57}$ This increasingly favorable lending climate no doubt gave Woodward confidence that his bold recommendations for a larger, better armed Navy would be well received both within Peru, where improved defenses at sea promised to better secure the nation's foreign and domestic commerce, and in the United States, where the contracts for Peru's new naval vessels would undoubtedly be let.

\footnotetext{
${ }^{55}$ Paul W. Drake notes that in 1923, Cumberland reported to the State Department in Washington that "Leguía did not really want him to reform public finances, but instead to serve as a magnet for loans [for Peru] through U.S. banks.” Drake, The Money Doctor in the Andes: The Kemmerer Missions, 1923-1933, 215.

${ }^{56}$ Lawrence Clayton uses the term "financial interlacing" to describe the growth in U.S. lending to Peru during Leguía's Oncenio. See Clayton, Peru and the United States: The Condor and the Eagle, 124-27.

${ }^{57}$ Barbara Stallings, Banker to the Third World: U.S. Portfolio Investment in Latin America, 1900-1986, Studies in International Political Economy (Berkeley: University of California Press, 1987), 256-57.
} 
Yet only part of Woodward's ambitious naval expansion proposal ended up becoming reality. Developed in consultation with Leguía and without the U.S. State Department's knowledge, his recommendations came as a complete surprise in Washington, where President Calvin Coolidge had recently taken up his predecessor's efforts to mediate the Tacna-Arica dispute between Peru and Chile. ${ }^{58}$ The State Department very quickly came to view Woodward's proposed naval buildup as profoundly destabilizing to the fledgling negotiations over those disputed territories. Stung by the independence with which Woodward had acted, Washington immediately applied the brakes to his proposed expansion of the Peruvian fleet and sought to refashion it in more modest, clearly defensive terms that would not enflame the delicate situation with Chile. Throughout the early months of 1924 Woodward worked to assess just how much of a fleet expansion Washington would deem acceptable in the current context, and by September Leguía had concluded just such a deal: turning to reliable old contacts at his favored shipbuilder, the Electric Boat Company of Groton, Connecticut, Leguía contracted for two R-type submarines and 24 torpedoes, as well as for the construction of the San Lorenzo submarine base that had been envisaged in the original Woodward proposal. ${ }^{59}$ Although Leguía fully intended to continue the expansion and modernization of the Peruvian fleet in the future and saw this scaled-down deal as merely a first step, the naval purchases his government would make throughout the rest of the Oncenio (consisting principally of two more R-type submarines from Electric Boat, for a total of four) never lived up to the expectations set by Woodward in his proposal of late

\footnotetext{
${ }^{58}$ U.S. President Warren Harding agreed to arbitrate the dispute in Washington beginning in early 1922, and his efforts were continued by Calvin Coolidge following Harding's abrupt death in August, 1923. See "Harding Invites Chile-Peru Parley: Note to Two Governments Says He Will Be Glad to Welcome Representatives in Capital," New York Times, 19 January 1922, 16. See also Clayton, Peru and the United States: The Condor and the Eagle, 137-38.

59 "Brief Summary," 8.
} 
1923. These acquisitions did, however, have two important effects: they made the submarine the operational backbone of Peru's fleet, and confirmed the Navy as Peru's first and most important line of national defense.

The submarine's rise to preeminence in the Peruvian Navy while that institution was under U.S. tutelage made sense not only in the context of Leguía's enduring belief in the submarine's suitability to Peru's particular defense challenges, but in view of its evolving place U.S. naval doctrine at the time as well. The U.S. Navy's civilian leaders had briefly entertained backing a British call to abolish submarines entirely following World War I, but had reversed course by the time of the Washington Naval Conference of 1922. Indeed in the early 1920s, American naval planners increasingly viewed submarines as integral to the U.S. Navy's future brand of warfare at sea - both in support of battle fleet operations and in coastal defense operations. This was evident in the Navy's commitment to build six large, long-range fleet submarines between 1921 and $1925 .^{60}$ Yet in the mid-1920s submarines were not yet, in naval historian George Baer's words, the "self-contained masters of the deep" they would ultimately become. Although the U.S. Navy was beginning to realize the

\footnotetext{
${ }^{60}$ Ernest Andrade, "Submarine Policy in the United States Navy, 1919-1941," Military Affairs 35, no. 2 (1971): 50. Andrade's assessment of the post-war U.S. Navy's outlook on submarines is more charitable than those offered by other historians. For example, William McBride argues that "Even after the U.S. naval hierarchy learned how close submarines had come to forcing Britain to capitulate early in 1917, its members minimized the effectiveness of the submarine threat...Although held hostage [during the war] by the submarine, no dreadnought had been sunk by one and the battleship remained supreme." He also notes that Admiral William S. Sims "and most of his colleagues, perceived the submarine threat to the battleship as minimal and easily countered by the battleship's higher speed," and as a result, during Sims's presidency of the Naval War College, the College "paid no attention to the submarine, except as it could support the strategy of the battleship." See William M. McBride, Technological Change and the United States Navy, 1865-1945, Johns Hopkins Studies in the History of Technology (Baltimore: Johns Hopkins University Press, 2000), 125-27. Robert O'Connell takes an even stronger line, arguing that naval officers' blind devotion to the battleship before, during, and after World War I prevented them from recognizing how new weapons, such as the submarine, were changing naval warfare. See Robert L. O'Connell, Sacred Vessels: The Cult of the Battleship and the Rise of the U.S. Navy (Boulder: Westview Press, 1991). Kenneth Hagan notes that during the 1920s and 1930s, American naval planners were "conditioned to think only in terms of decisive engagements between surface fleets of capital ships, and conveniently repelled by the brutal effectiveness of submarine guerre de course...made fundamental errors with submarines and their ordnance." See Hagan, This People's Navy: The Making of American Sea Power, 274-75.
} 
potential of fast-moving, long-range submarines to contribute to fleet operations far from shore, and although American Navy planners were beginning to envisage a future in which long-range submarines would be integral to offensive fleet operations aimed at establishing and maintaining command of the seas, in the early 1920s small coastal defense submarines remained the heart of the U.S. submarine force ${ }^{61}$ Fundamentally, U.S. naval doctrine of the early 1920 s confirmed, the submarine remained a defensive weapon. It is therefore not surprising that officers of the U.S. naval mission in Lima, who came of age professionally during the period of the submarine's operational infancy, would see it as a tool ideally suited for Peru - a nation whose central security concerns (refusing the approach of an enemy fleet to its shores and ensuring the safety of its ocean-going commerce) were inherently defensive and revolved around ensuring coastal security.

In the end, the Peruvian Navy's embrace of submarines during Leguía's Oncenio demonstrates two things very clearly. First, it shows that, although their dual status at times complicated U.S. diplomacy, members of the U.S. naval mission took their roles as Peruvian naval officers seriously. They developed close, cooperative relations with their champion, Leguía, and worked earnestly to acquire the U.S.-built submarines he believed were essential to Peru's defenses. Acting as Peru's highest-ranking naval officer, Admiral Woodward made Leguía's case for a fleet expansion that had as its raison d'être an inherently Peruvian goal, the strengthening of the nation's defenses vis-a-vis Chile, even though it conflicted with U.S. interests. Although Woodward's efforts did not bear the amount of fruit Leguía had desired, they were nevertheless instrumental in pushing the Peruvian president's longstanding efforts to acquire U.S.-built submarines over the proverbial finish line. And second, in Peru's

\footnotetext{
${ }^{61}$ Baer, One Hundred Years of Sea Power: The U.S. Navy, 1890-1990, 62.
} 
embrace of the submarine we can also see the shrewdly-played hand of the dictator Leguía, who by the time he succeeded in acquiring submarines (the one naval arm he saw as indispensible to meeting Peru's unique security challenges) from the United States, had spent portions of three decades pursuing them. Leguía had not only argued the merits of U.S.-built submarines over those from other nations. He secured a naval mission whose institutional views on this major issue comported perfectly with his own, and he successfully enlisted that mission - and by extension the power and prestige of the United States - in the cause of advancing his own naval priorities.

\section{CREATING A NATIONAL AVIATION SYSTEM}

As it had with submarines, the importance Leguía attached to coastal defense led the Peruvian Navy to embrace another new, promising technology of warfare during the 1920s: the airplane, whose promise the recent war in Europe had also begun to demonstrate.

Although the war had not answered all doubts about naval aviation within the United States, and although debate about the utility of aircraft in naval warfare raged within the U.S. Navy in the years that followed, consensus on aviation emerged early within Peruvian naval establishment while under the direction of the U.S. naval mission. ${ }^{62}$ That is because Peru, whose geography, principal security objectives, and limited fiscal resources precluded it from building a large fleet and pursuing an offensive naval strategy aimed at achieving control of the sea, could view aviation assets much as it did submarines - not as supplements to a great

\footnotetext{
${ }^{62}$ In the United States, the Navy's General Board reported in June 1919 that "to ensure air supremacy, to enable the United States Navy to meet on at least equal terms any possible enemy, and to put the United States in its proper place as a Naval power, fleet aviation must be developed to the fullest extent...A naval air service must be established, capable of accompanying and operating with the fleet in all parts of the world." Many within the Navy disagreed, favoring a continued emphasis on battleships and pursuit of decisive surface battles. For more on this debate, and on Brigadier General William "Billy" Mitchell's efforts to demonstrate the airplane's utility in naval warfare, see Stephen Howarth, To Shining Sea: A History of the United States Navy, 1775-1991, 1st ed. (New York: Random House, 1991), 330-34.
} 
armada of powerful surface vessels, but as a cornerstone of an economical, defensivelyminded naval capability. Moreover, the development of naval aviation aligned perfectly with Leguía's Patria Nueva vision of national economic development because advances made in the naval-military aviation realm held the promise of spillover benefits for the civilian economy. Indeed, the U.S. naval mission's efforts at developing Peruvian naval aviation in the 1920s would give immeasurable aid to the creation of a national system of aviation aimed at knitting together Peru's distinct coastal, mountain, and Amazonian regions, as well as the forging of closer commercial links between Peru and the United States.

The emphasis the U.S. naval mission placed on aviation from its earliest days is clear from the pages of the Peruvian Navy's professional journal, the Revista de Marina. Between 1922 and 1925 the Revista translated and republished a number of essays on the theory and practice of naval aviation from the U.S. Naval Institute's Proceedings. Although written by U.S. officers from a clearly North American perspective, each essay contained lessons relevant to the Peruvian Navy's development of a naval air service. The first such article, penned by U.S. Navy Commander D.E. Cummings and published by the Revista in late 1922, noted the possibilities and limitations of naval aviation, and posited that airplanes' greatest value in naval warfare lay in scouting and attacking enemy naval vessels, aerial combat against other aircraft, and protecting friendly vessels in escort duty. ${ }^{63}$ Of special significance to the Peruvian Navy, given its emphasis on defending the coast against Chilean naval attack, was Cummings's observation that aircraft were "particularly suited for scouting work, on account of their speed and vision," which enabled them to spot enemy surface vessels and submarines at a distance and alert friendly forces to the likelihood of an impending attack.

\footnotetext{
${ }^{63}$ D.E. Cummings, "Empleo de los Aparatos de Aviación en la Guerra Naval," Revista de Marina VII, no. 6 (Noviembre-Diciembre 1922): 682. Version published in the United States was D.E. Cummings, "Use of Aircraft in Naval Warfare," United States Naval Institute Proceedings 47, no. 11 (November, 1921).
} 
Aircraft were especially valuable in scouting operations against submarines, he noted, because their position high above the water gave them the ability to spot submarines that were submerged, but operating (as most at the time did) just below the surface - a point that no doubt resonated with Peruvian officers who, like Leguía, were concerned about Chilean superiority in submarines in the early 1920s. Because the Peruvian Navy was concerned first and foremost with coastal defense and operations within the Peruvian littoral, the factors Cummings listed as limiting the airplane's usefulness in scouting operations (its limited operating radius, limited radio range, and defensibility) were less of a concern than they were to the globally-minded, "blue water" U.S. Navy. ${ }^{64}$ Because Peruvian naval aircraft would conduct scouting operations relatively close to shore, and would be responsible for patrolling a smaller area than their U.S. counterparts, they would not have to conform to the same exacting standards that governed U.S. acquisitions of naval planes.

Subsequent articles selected by Davy for republication in the Revista de Marina addressed the types of aircraft best suited to warfare at sea as well as the roles they should fulfill in support of fleet operations. The November-December 1923 issue, for example, contained an article by U.S. Navy Lieutenant DeWitt Ramsey entitled "The Development of Naval Aviation," which detailed the characteristics required of aircraft engaged in scouting and observation, bombing, and aerial combat operations. Ramsey wrote that "large fuel capacity" and "seaworthiness" were essential features of naval aircraft "adaptable to long distance scouting flights over the sea," and that bombing planes should be capable of "short run" take-offs from the decks of aircraft carriers while carrying a "full military load." ${ }^{\circ 5}$

\footnotetext{
${ }^{64}$ Ibid, 683.

${ }^{65}$ DeWitt C. Ramsey, "El Desarrollo de la Aviación Naval," Revista de Marina VIII, no. 6 (NoviembreDiciembre 1923): 694-699.
} 
Scouting and bombing of approaching enemy vessels would be essential missions for Peruvian naval aviation, but these specific criteria were less important to the Peruvian Navy because scouting over Peruvian coastal waters involved shorter distances. Moreover, no Peruvian naval aircraft - whether for scouting or bombing of enemy vessels - would fly from the decks of carriers. But the publication of Ramsey's essay underscored that in the future, airplanes would serve as the eyes of the Peruvian Navy in carrying out its vital coastal defense mission. In practice, it also meant that Leguía and his U.S. naval mission would have greater flexibility in choosing the kinds of aircraft with which to equip the Navy's aviation service.

The cause of Peruvian naval aviation received a significant boost with the arrival of Harold B. Grow (Commander, U.S. Navy), an aviation expert whose Proceedings article on the "Tactical Employment of Naval Aircraft" was published by the Revista shortly after he joined the U.S. naval mission in Peru in January 1924. Charged personally by Leguía with directing the development and training of Peruvian naval aviation service, Grow came with a well-established reputation as an aviation expert, and clear views on the role aviation assets should play in naval warfare. ${ }^{66}$ Accordingly, his 1924 essay focused less on the types of aircraft best suited for naval aviation, or the exact specifications required, and more on the tasks naval aviators should carry out in order to effectively support fleet operations. In a finding ideally suited to Peru's strategic situation, for example, he differentiated between

\footnotetext{
${ }^{66}$ A 1912 graduate of the U.S. Naval Academy, Grow joined the U.S. Navy's aviation service in the spring of 1918 and served with the Northern Bombing Group until the end of World War I. Following the war, he served at the Hampton Roads Naval Air Station in Virginia, where he participated in naval bombing tests and, remarkably, set a world hydroplane flight record of 21 hours, 12 minutes. Just before joining the U.S. naval mission in Peru, Grow coordinated the Navy's training of spotter pilots and authored its guide to aerial artillery. As noted by the Revista de Marina upon his appointment, Grow was "considered an authority in the tactical employment of aviation, both for attack and defense." A brief biography of Grow was published in the Revista shortly after his arrival. See "Nuevo Jefe del servicio de Hidro-aviación," Revista de Marina IX, no. 1 (Enero y Febrero 1924): 113-115.
} 
"strategic" and "tactical" aerial scouting. Strategic scouting for enemy vessels, Grow wrote, meant gaining "information as to the location, strength, disposition, course, etc. of the enemy main body and screen." It was a function for which naval aircraft were uniquely suited, he continued, because under favorable weather conditions, a single aircraft aloft in close proximity to a friendly fleet could give that fleet seaward visibility of up to forty miles. Although it would be difficult to distinguish the specific types of enemy vessels at such a distance, he noted, "the mere knowledge of their presence would be invaluable" even if the plane were prevented from drawing near the enemy fleet's defensive screen to collect more detailed information. ${ }^{67}$ Simply alerting friendly vessels to the approach of an enemy fleet would buy them vital situational awareness and, importantly, time to prepare for battle.

Not surprisingly, Grow believed that naval aircraft also had critical roles to play once battle had arrived. Securing "absolute control of the air" was air power's first function amid hostilities, he argued, a task that involved seizing local control of the air and maintaining it throughout the period of the main fleet engagement. This command of the skies would be secured by fighter aircraft whose sole purpose was to attack any scouting, fighter, or bomber aircraft the enemy fleet might launch in the course of its advance. But, Grow cautioned, battle against an enemy fleet would not negate the need to keep scouting planes in the air. Indeed the strategic (longer-range) scouting flights that preceded hostilities would give way, in battle, to tactical scouting flights aimed at supplying commanders with "information concerning the enemy main body," including damage inflicted on enemy vessels and aircraft, "in order to assist the commander-in-chief to dispose his force to best advantage."

\footnotetext{
${ }^{67}$ Harold B. Grow, "Empleo táctico de la Aviación Naval," Revista de Marina IX, no. 3 (Mayo y Junio 1924): 161-162.
} 
In Grow's view, still somewhat controversial in U.S. Navy circles, aviation was clearly an indispensible element - perhaps the indispensible element - of naval power. In laying out his ideas he was careful to acknowledge, however, that as a new discipline within the profession of arms, aviation had not been shaped by a highly-developed body of theory and had not had the benefit of years of test and evaluation. Indeed, he concluded, when it came to the young business of naval aviation "for once we can not study history and the actions of great leaders for our own edification. True, certain principles exist in aerial combat...but to no source can we turn for any experience in working out our plans for the coordination of tactics of air units operating with the fleet. ${ }^{, 68}$ Clearly Grow had a faith in the utility of air power to naval warfare, and expressed no reservations about building Peru's naval air capability from this very limited base of experience.

By the time of Grow's appointment as the naval mission's point-man on aviation in early 1924, Leguía's push for an aviation service within the Peruvian Navy had already gained significant momentum. Indeed a month before Grow's arrival in Lima, Admiral Woodward, in his case before the Peruvian congress for a naval buildup centered on submarines, pointed to aviation as an essential component of an effective national defense. Like submarines, he argued, naval aircraft delivered the nation more capability per dollar than significantly more expensive surface vessels could. Given Peru's limited resources, aircraft could therefore help close the capability gap with the Chilean Navy without forcing Peru down the financially ruinous course of building its surface fleet to numerical parity with that quantitatively and qualitatively superior force. As Woodward wrote in a strategy document that accompanied his proposal to the congress, that was because the Navy's

\footnotetext{
${ }^{68} \mathrm{Ibid}, 163-165$.
} 
defensive orientation and emphasis on coastal defense meant it could content itself with "minor attacks" aimed at "reducing the enemy's relative superiority by putting some of his ships out of action." Such attacks would do much to exhaust and frustrate the advance of a Chilean fleet to Peruvian shores, and would no doubt help prevent the landing of a foreign army on Peruvian soil. In an assessment remarkably consistent with the views Grow expressed in his Revista essay, along with submarines, Woodward argued that naval aircraft would serve as the eyes of the Peruvian Navy (and indeed, of the nation as a whole): they would give the Peruvian fleet greater visibility on lurking threats, and would "impose much caution in the employment by the enemy of surface craft, be they battleship, cruiser or destroyer." And importantly, Woodward noted, like submarines, aircraft would deliver those capabilities at a lower cost than a comparable number of surface ships. ${ }^{69}$

Not surprisingly given the Peruvian Navy's emphasis on coastal defense, the aviation portion of Woodward's proposal was built around the scouting mission. But given Peru's paucity of fiscal resources, it also envisioned a naval air service in which all naval aircraft would do double duty as both scouts and attack planes. Although tests in the United States in the early 1920s were validating the airplane as a useful weapon against surface vessels, it was clear, Woodward stressed, that for Peru they would be most useful "in locating the enemy during his approach to the coast," whether they be "behind a line of enemy scouting ships or behind a smokescreen made by enemy destroyers." Control of the air (and therefore, success) in naval warfare, he cautioned, would be impossible to establish without the longrange early warning that aircraft could provide. With sufficient warning of approaching enemy vessels, Peru's naval air service could transition from strategic scouting to tactical

\footnotetext{
${ }^{69}$ Clark H. Woodward, "The Strategy and Naval Policy of Peru,", , Clark H. Woodward Papers (Collection 297), Box 2, Operational Archives, Naval History and Heritage Command, Washington, DC.
} 
attack with relative ease - dropping depth charges in the vicinity of submerged enemy submarines, combating enemy planes in the air, or even, in Woodward's words, "spreading gas over a considerable extent of the ocean, paralyzing enemy surface ships" - all while remaining safely out of range of enemy anti-aircraft guns. ${ }^{70}$

Amid the diplomatic fallout following Woodward's December 1923 naval expansion proposal to the Peruvian congress, though, the planned purchase of twenty-five naval aircraft was cut to zero. In fact, the scaled-back naval purchases Leguía made in 1924, which included two of the six submarines Woodward had envisaged, included nothing for Peru's fledgling naval aviation service. These cuts did not, however, represent a death knell for Grow's early naval aviation efforts. That is because the lion's share of his early energies went into the decidedly non-controversial areas of education and training. This emphasis meant that during much of his first year in Peru, Grow would have to devote considerable time not to acquiring aircraft, but to establishing the basic structure of Peruvian naval aviation and developing a training program. To accomplish this, he focused on undoing the work of a short-lived French aviation mission that Leguía had invited to Peru during the earliest days of is Oncenio. One of the few successes that that French mission achieved during its disastrous three-year tenure in Lima - which Lawrence Clayton notes was marked by "little success, undermined in part by spectacular accidents" - was the creation in 1922 of

\footnotetext{
${ }^{70}$ Clark H. Woodward, "Estudio Sobre El Plan Naval del Peru, 1924," Clark H. Woodward Papers (Collection 297), Box 2, Operational Archives, Naval History and Heritage Command, Washington, DC. In this study, the basis for his proposal to the Peruvian congress, Woodward identified as the "Mission" of Peru's naval air service "to obtain control of the air." The vital role of scouting, so important to effective coastal defense, is clear in his discussion of "Doctrine." To achieve the goal of control of the air, he identified the specific roles of naval aircraft as: locating the enemy and informing on his movements; denying similar information to the enemy's air forces; searching for submerged enemy submarines; attacking enemy surface ships with gas; discovering the adversary behind a scouting column of surface vessels, or behind a smokescreen; creating smokescreens to protect friendly forces; attacking major enemy vessels with bombs and torpedoes, while impeding similar attacks by enemy aircraft; and observing the impact of shots on enemy vessels, enabling corrections (to increase effectiveness).
} 
an aviation school staffed by French, British, and American instructors. ${ }^{71}$ Upon his arrival Grow tore down this existing structure of aviation education, which had housed civil, military, and naval aviation in one organization, and, in accordance with Leguía's wishes, initiated a program aimed at Americanizing Peruvian naval and military aviation and consolidating it under the watchful eye of the U.S. naval mission.

The process unfolded quickly, beginning with the construction of a naval air base and a new aviation school at Ancón, just north of Lima. By September of 1924 the mission was able to report to Washington that due to Grow's efforts, construction of the commanding officer's quarters, general store house, power plant, cuartel (barracks), and water management systems of the school had been initiated. Actual flying time during those early months was limited, though, by a lack of suitable training aircraft. ${ }^{72}$ It was a shortage for which Grow sought immediate redress. Two months earlier, in July, Woodward had informed ONI that although his ambitious call for twenty-five naval aircraft had been scuttled, the naval ministry had placed an order with the Boeing Corporation of Seattle, Washington, for three training planes "exactly like the lot being built for the U.S. Navy," which President Leguía had authorized for the naval aviation school at Ancón. A hands-on manager, Grow took the lead in negotiating the deal with Boeing, securing funds for the purchase from the Peruvian treasury, bargaining with Boeing for a price of $\$ 16,300$ per plane, and securing a promise that the new aircraft would be delivered to Peru in time for the

\footnotetext{
${ }^{71}$ Clayton, Peru and the United States: The Condor and the Eagle, 127-28. See also Masterson, Militarism and Politics in Latin America: Peru from Sánchez Cerro to Sendero Luminoso, 31.

72 The naval mission's September 1, 1924 report of operations to ONI noted that only two aircraft were available for regular "communication" flights between Ancón and Callao, as well as for the "breaking in of students.” Senior Naval Mission Member Present (Davy) to ONI, September 1, 1924, RG 38, Office of Naval Intelligence, File E-9-d (12524), Box 761, National Archives.
} 
inauguration of the aviation school on January $1,1925 .{ }^{73}$ An early product of the close, personal relationship Grow and Leguía developed between 1924 and 1930, this acquisition helped ensure that the fledgling naval aviation service's survival. Moreover, by bringing U.S.-built aircraft into the Navy's inventory, it helped solidify U.S. influence over Peru's nascent military-naval aviation establishment.

As Grow labored to establish a U.S.-style naval aviation service, Leguía's broader efforts to draw U.S. commercial aviation interests to Peru also began to bear fruit. Forging an integrated, "modern" national economy was a central objective of the Patria Nueva program of economic development, and, he believed, knitting together Peru's distinct coastal, mountainous, and Amazonian regions was essential to the task. Very early on, therefore, Leguía had made establishing air linkages between these regions a priority. In 1921, for example, he had offered a prize for the first trans-Andean flight from Lima to the Peruvian Amazon port of Iquitos - a competition won by American aviator Elmer "Slim" Faucett, who later established one of Peru's first commercial airlines. Because of Leguía's desire to establish a national aviation system and his favorable attitude toward foreign business interests, in the mid-1920s Peru became a magnet for pilots and aviation interests looking to either set new flight records or gain an upper hand in the struggle to corner the emerging South American commercial air market. ${ }^{74}$ By 1928 , the maturation of aviation technologies had reduced overall risk to levels acceptable to major investors, and an intense competition quickly developed between two new companies for the Peruvian market, one established by

\footnotetext{
${ }^{73}$ Naval Mission Head (Woodward) to ONI, July 15, 1924, contained in "Excerpts from Monthly Reports of Operations" of the U.S. Naval Mission to Peru for 1923-24, Clark H. Woodward Papers (Collection 297), Box 2, Operational Archives, Naval History and Heritage Command, Washington, DC.

${ }^{74}$ Clayton, Peru and the United States: The Condor and the Eagle, 131-33.
} 
Faucett with a group of Peruvian investors, and the other backed by the North American giant Pan American Airways and its aggressive founder, Juan Trippe.

To manage this competition Leguía made a decision in early 1928 that united Peruvian naval, military, and commercial aviation in a single bureaucracy and cemented American control over it: he appointed Commander Grow, by then one of his most trusted aides, to the newly created position of Director General of Aviation. ${ }^{75}$ As naval mission chief A.G. Howe later noted in a report to Washington, the appointment had the effect of bringing all aviation activities in the country "directly under his [Grow's] orders."

Moreover, it ensured that Howe, as the head of the naval mission and Chief of the Peruvian General Staff, would "at all times be posted in connection with the aviation activities of Peru." As the competition heated up between Faucett's company and Pan American for the right to establish an international passenger, mail, and cargo route between Peru and the United States, Howe noted, Grow's position was "daily growing in importance to the country [Peru] and also to the United States." ${ }^{, 76}$ U.S. foreign policy makers in Washington agreed with Howe that Grow's position was vital to the furthering of American commercial aviation interests in Peru. On January $19^{\text {th }}$, Secretary of State Frank Kellogg had advised the U.S. Ambassador to Peru, Miles Poindexter, that it was "highly desirable" that Leguía not grant

\footnotetext{
${ }^{75}$ See "Brief Summary," 17. Some sources note that Grow was appointed "Inspector General of Aviation." This brief summary of U.S. naval mission activities between 1920 and 1928 notes that "The President signed a Supreme Decree in August, 1928, creating (and regulating) Naval aviation under the Minister of Marine, Army aviation under the Ministry of Marine and Commercial aviation under the Minister of Interior. the same decree created the office of Inspector General of Aeronautics, the technical director and consultant of the three activities. Commander H.B. Grow was immediately appointed to fill the office." The February 1929 monthly report of the head of the U.S. Naval Mission (Howe) to ONI notes that, well after Grow had been given de facto control over Peruvian aviation, the law that, de jure, consolidated all aviation activities within the Ministry of Marine (and re-designated it the Ministry of Marine and Aviation) was passed by the Peruvian congress over "considerable opposition," and that its passage had only been secured by employing "steam roller tactics." See Head of Naval Mission (Howe) to ONI, on "Operations, January, 1929," February, 1929, RG 38, Entry 48-A (Pan-American Affairs Division), Box 4, National Archives.

${ }^{76}$ Head of Naval Mission (Howe) to ONI, on "Duty and work of the Naval Mission in Peru," October 10, 1928, RG 38, Entry 48-A (Pan-American Affairs Division), Box 4, National Archives.
} 
any aviation concession until Pan American's representative in Peru had had the time to develop his company's "projects" in the country. Moreover, he wrote, in the future Pan American "would associate the Naval Air Service of Peru" (Grow's creation) in its work. Two days later, Poindexter informed the Secretary, approvingly, that Leguía had placed the matter of the concession entirely "in the hands of Grow," who had recently established the naval air service's first link across the Andes, and who was now poised to recommend that the concession be awarded to Pan American. ${ }^{77}$

In addition to giving U.S. commercial aviation interests the upper hand in the competition for the Peruvian market, Grow's appointment underscored the importance of the U.S. naval mission to broader American interests in Peru. With this single decision by Leguía, Howe and U.S. diplomats noted approvingly, an enormous amount of diplomatic power had been invested in a mid-level U.S. naval officer - one who was a member of the dictator Leguía's inner circle, and who, by virtue of that access, was in a strong position to advance the cause of U.S. commercial aviation interests in Peru. And although by 1928 U.S. naval mission members had long held sway over the Peruvian Navy, Grow's appointment represented a new, more intimate level of U.S. involvement in Peru's sovereign affairs. His support of the Pan American bid, and Leguía's subsequent approval of it, stands as the clearest example of the U.S. naval mission lending direct support to American commercial interests throughout its tenure in Peru. Grow's place within the Peruvian bureaucracy gave the United States a measure of influence with Leguía that no civilian diplomat could hope to achieve. In so doing, it directly benefited U.S. commercial interests and afforded U.S. policy significant amount of influence over Peru's economic future.

\footnotetext{
${ }^{77}$ See Secretary of State to the Ambassador in Peru (Poindexter), January 19, 1928, and The Ambassador in Peru (Poindexter) to the Secretary of State, January 21, 1928. Both contained in Foreign Relations of the United States, 1928, Vol. I (Washington, DC: U.S. Government Printing Office), 800-801.
} 
As Director General of Aviation, Grow continued to facilitate advances in both naval and commercial aviation until Leguía's overthrow in August of 1930 ended his tenure and forced the U.S. naval mission to relinquish its executive authority over the Peruvian Navy. ${ }^{78}$ In May of 1929, for example, he directed Leguía's establishment of a joint Navy-Army Air Corps, which required that all Navy and army pilots be trained to fly missions in support of ground and sea operations. That same month, new naval mission head William S. Pye (Captain, U.S. Navy, who held the rank of Contraalmirante in the Peruvian Navy) reported the successful commencement of air mail service between Peru and the United States. ${ }^{79}$ In August of that year, Grow oversaw an increase in the size of the student body of the Escuela Naval, by twenty cadets navales, in order to "provide for more aviators which will be needed for an expanding aviation service." ${ }^{80}$ And from late 1929 through early 1930, he accelerated his longstanding efforts to procure U.S.-built aircraft for Peru's naval air service - an effort that ultimately fell apart amid the freezing of international capital markets following the stock market crash of October 1929 and the advent of a worldwide economic depression.

\footnotetext{
${ }^{78}$ As will be discussed in Chapter 4, Grow's close relationship with Leguía led him to undertake an active role in quelling the anti-Leguía uprising, which began in the southern Peruvian city of Arequipa in August, 1930. Grow did this in violation of the Peruvian aviation law passed in early 1929, and in violation of the regulations that governed his conduct as a member of the naval mission. He was captured by forces friendly to SánchezCerro in the course of his mission.

${ }^{79}$ See Head of Naval Mission to Peru (Pye) to ONI, on “Operations for Month of May," May 31, 1929, RG 38, Entry 48-A (Pan-American Affairs Division), Box 4, National Archives. Among the first letters sent by air mail from Peru to the United States was a short note from U.S. Ambassador Alexander Moore to President Herbert Hoover, dated May 3, 1929. In his response, Hoover noted that the letter had taken thirteen days to arrive (a significant improvement over service by sea), and that he had "no doubt that in time this service will be speeded up." See U.S. Ambassador to Peru (Moore) to President Herbert Hoover, May 3, 1929, and President Herbert Hoover to U.S. Ambassador to Peru (Moore), May 17, 1929 - both contained in Herbert Hoover Presidential Papers (Foreign Affairs), Box 996, Herbert Hoover Presidential Library, West Branch, IA. In February, 1929, Pan American and W.R. Grace \& Co., Peru's leading passenger and freight carrier at sea, formed Pan American - Grace Airways (known as "Panagra"); as Lawrence Clayton notes, for forty years following the company's formation, Panagra "dominated the airways between Peru and the United States, serving as one of the principal conduits for the flow of information, people, materials, and culture between the two countries." See Clayton, Peru and the United States: The Condor and the Eagle, 137.

${ }^{80}$ Head of Naval Mission to Peru (Pye) to ONI, August 31, 1929, RG 38, Entry E-194, Box 1, National Archives.
} 


\section{CONCLUSION}

When it relinquished command over the Peruvian Navy in August of 1930, the U.S. naval mission could claim an impressive record of success over its decade-long tenure. Improved academic and physical standards at the Escuela Naval, together with Captain Davy's emphasis on professionalism and his dedication to improving the academy's facilities, transformed it into a leader in South American naval and military education and shaped a generation of young officers favorably disposed toward the United States and the U.S. Navy. At the same time, the naval mission delivered on Leguía's desire to acquire modern, U.S.-built submarines and establish a base of expertise within the Peruvian Navy's officer corps in their use. In so doing, as Robert Scheina notes, the U.S. naval mission to Peru firmly established submarines as a cornerstone of Peruvian national defense and laid the groundwork for what would become, in subsequent decades, Latin America's premier submarine force. ${ }^{81}$ And finally, the mission established a naval air service that, together with the submarine, became an integral part of Peru's naval defenses at the same time that it served as the seedbed for commercial aviation developments that both propelled Leguía's Patria Nueva vision forward and materially aided U.S.-based aviation interests.

These successes did come at a cost, however. Throughout the 1920s, the naval mission's place within the Peruvian state apparatus, its broad authorities, and its members' dual status as Peruvian officers who enjoyed close relations with Leguía himself, helped firmly align U.S. policy with an autocratic leader. Indeed, the dictator's fall from power in the depths of the Great Depression would inaugurate a period of violent political turmoil within Peru, a defining feature of which was a rising tide of anti-U.S. sentiment within the

\footnotetext{
${ }^{81}$ Scheina, Latin America: A Naval History, 1810-1987, 362, n.20.
} 
Peruvian population. A detailed examination of the challenges that the naval mission's unique structure and work posed for U.S. foreign policy is the subject of the next chapter. 


\section{CHAPTER 3: CHALLENGES, 1920-1933}

For all the successes it achieved in the areas of naval education, submarines, and aviation, the U.S. naval mission's work in Peru from its arrival in 1920 until Leguía's overthrow in August 1930 came at a cost. Its members' dual status as officers in the U.S. and Peruvian navies meant that their activities often fell into gray areas between U.S. and Peruvian sovereignties, and posed significant challenges for U.S.-Peruvian relations. The complications flowed from the fact that, on the one hand, naval mission members were sent to Peru as instruments of U.S. policy calculated to achieve certain national objectives, while on the other, they were to serve as integral parts of the Peruvian government and labor on its behalf to build a more efficient, effective Navy for that nation. Over time, mission members' dual status proved more difficult to manage than U.S. decision makers had thought possible at the outset, in large part because Leguía, far from being a mere vassal of Washington, proved adept at using the mission to advance his own foreign and domestic priorities. The challenge was no less pronounced after Leguía's overthrow in August of 1930, when naval mission members relinquished command of the Peruvian Navy and assumed an advisory status that still proved diplomatically difficult. In the end, from its arrival in 1920 to its withdrawal in early 1933, the actions taken by the U.S. naval mission to Peru often contributed directly to more difficult relations between the United States and Peru.

\section{"VERY CORDIAL" RELATIONS}

Initially the dual status of American officers aroused little concern in Washington. The Woodrow Wilson administration had agreed to send the mission to Peru on the 
understanding that U.S. personnel would act mainly as trainers, consistent with Leguía's request for American officers to "reorganize and direct" the Peruvian Navy and enact structural reforms. ${ }^{1}$ Indeed, once the mission was in place the rules governing its activities stated that members' roles were to be limited to "merely those essential to the proper organization by them of the Peruvian Navy, and the instruction and training of its officers and other personnel."2 The United States had had no previous experience sending such missions before approving Leguía's request, but in the Wilson administration's view the arrangement was consistent with its expansive hemispheric policy aimed at aiding Latin American nations "as far as possible in all cases where there is no good reason not to do so." 3 The desire to extend such assistance was especially strong the case of Peru, given Leguía's strongly pro-American pronouncements and obvious desire to invite U.S. capital and expertise into the country. As a result, acceding to Leguía's request that U.S. officers assume actual command of the Peruvian Navy was seen by American foreign policymakers in Washington as a means - if a unique one - of facilitating the naval mission's work and keeping an enthusiastic ally happy. Indeed, there is no evidence in the records of either the State Department or Navy Department to indicate that, in the mission's earliest days, American officials were worried that American personnel might be called upon to direct Peruvian forces in a domestic or international conflict.

\footnotetext{
${ }^{1}$ Interim U.S. Minister to Peru to Secretary of State, October 22, 1919, U.S. Legation Lima, Vol. 175, RG 84, National Archives.

${ }^{2}$ Secretary of State to U.S. Chargé d'Affaires in Peru (Sterling), March 13, 1921, RG 59, File 823.30/24, National Archives.

${ }^{3}$ The United States had sent naval advisers to Brazil to assist in the establishment and development of a naval war college, but had not committed to sending a formal naval "mission" until it approved Leguía's request for such a mission for Peru. Through his diplomatic representative in Washington, Leguía's initial request for a U.S. naval mission specified that it would "reorganize and direct" Peru's Navy. See Interim U.S. Minister to Peru to Secretary of State, October 22, 1919, U.S. Legation Lima, Vol. 175, RG 84, NARA. For the quoted statement of policy, see Secretary of State to Secretary of the Navy, January 14, 1920, RG 59, File 823.30/5, NARA.
} 
The State Department expressed little concern about the naval mission's unique status even as it strengthened ties with Leguía's increasingly dictatorial administration. In November of 1921, for example, the ardently pro-Leguía American Chargé d'Affaires in Lima, Frederick Sterling ${ }^{4}$, urged U.S. support for the "honest and progressive" Leguía despite the fact that earlier that year he had launched an all-out assault on Lima's independent press (including the seizure of one of Lima's largest daily newspapers, $\mathrm{La}$ Prensa), closed the nation's oldest and most storied university for spreading anti-government "propaganda," and began systematically arresting and detaining "political suspects" he deemed threats to his government. ${ }^{5}$ Four months later Sterling reported, approvingly, that through such repressive measures Leguía had largely succeeded in neutralizing political resistance to his administration, and that the successful enactment of such Americanizing reforms as the establishment of a Peruvian reserve bank "patterned on the lines of the United States Federal Reserve Act” had done much to enhance both Leguía’s personal "prestige"

\footnotetext{
${ }^{4}$ Sterling served as Chargé d'Affaires between the departure of U.S. Ambassador William Elliott Gonzales on October 11, 1921 and the arrival of Miles Poindexter as Ambassador on April 20, 1923. See "Chiefs of Mission for Peru," Office of the Historian, U.S. Department of State, accessed June 12, 2012 , http://history.state.gov/departmenthistory/people/chiefsofmission/peru.

${ }^{5}$ For Chargé Sterling's late 1921 assessment, see U.S. Chargé d'Affaires in Peru to Secretary of State (Confidential), November 29, 1921, RG 84, Vol. 182, National Archives. In March, 1921 government forces stormed the Lima offices of La Prensa, arrested its staff, seized its assets, and resumed publication under government control. For the rest of Leguía's Oncenio, La Prensa would serve as the government's official "mouthpiece." For Leguía's assault on La Prensa, see U.S. Minister to Peru to Secretary of State, March 23, 1921 and March 24, 1921, RG 59, Files 823.00/381 and 823.00/382, National Archives. As he prepared to orchestrate his reelection in 1924, Leguía threatened Lima's largest and most widely-read newspaper, $E l$ Comercio, with "the same fate as La Prensa should it become bold in assailing" his administration. See "Report on General Conditions Prevailing in Peru During the Previous Month," May 6, 1924, RG 59, File 823.00/455, National Archives. In March of 1921, government forces shut down the University of San Marcos in Lima, reopening it the next year under leadership deemed to be politically reliable. See "Report on General Conditions Prevailing in Peru During the Previous Month," February 20, 1922, RG 59, File 823.00/417, National Archives. In December, 1921 Chargé Sterling reported that "incarcerating or deporting all persons in any way tainted by association with supposed new revolutionary activities" appeared to be the policy of the Leguía government. See "Report on General Conditions Prevailing in Peru During the Previous Month," December 7, 1921, RG 59, File 823.00/413, National Archives.
} 
and that of the United States within Peru. ${ }^{6}$ Washington's satisfaction with the stabilizing political situation in Peru and the promise it held for U.S. interests ensured that when Leguía moved to amend the Peruvian Constitution in May 1922 to permit his reelection at the end of his five-year term of office, the State Department offered no objections. ${ }^{7}$ As the United States moved closer to Leguía throughout these critical months of late 1921 and early $1922-$ months when Leguía consolidated his dictatorship under Washington's watchful, approving eye - American diplomats and naval leaders consistently referred to the naval mission as a critical contributor to the all-important growth of U.S. "prestige" in Peru.

U.S. ties with Leguía grew so close during the naval mission's first year that when concerns did arise about what status U.S. officers should adopt in the event of a revolutionary disturbance against the dictator - or worse, an international war against one of Peru's neighbors - they were given little credence. As noted earlier, when in the midst of Leguía's efforts to consolidate his rule in early 1922 the State Department's solicitor concluded that mission members' contracts appeared to obligate them to fight on behalf of the Peruvian government should they (as members of the Peruvian Navy) be ordered by Leguía to do so, Secretary of State Charles Evans Hughes argued that the United States should rely on the "judgment and discretion" of the individual officers to avoid being pulled into such a murky situation. ${ }^{8}$ The benefits of maintaining a naval mission in Peru that met Leguía's needs, State Department and Navy leaders agreed, outweighed the risks that could flow from the unique

\footnotetext{
${ }^{6}$ U.S. Chargé d'Affaires in Peru to Secretary of State, March 9, 1922, RG 59, File 823.00/418, National Archives.

${ }^{7}$ U.S. Chargé d'Affaires in Peru to Secretary of State, "Report on General Conditions Prevailing in Peru During the Previous Month," May 15, 1922, RG 59, File 823.00/421, National Archives.

${ }^{8}$ For the solicitor's position, see State Department Solicitor Letter to Secretary of State, February 15, 1922, RG 59, File 823.30/23, National Archives. For Secretary Hughes's view, see Secretary of State to American Chargé d'Affaires in Lima (Sterling), March 13, 1922, RG 59, File 823.30/24, National Archives.
} 
arrangement permitting its members to serve simultaneously in the U.S. and Peruvian navies. Besides, Hughes and U.S. Navy leaders further agreed, by mid-1922 information from the U.S. legation in Lima confirmed that Leguía had achieved a virtually unassailable position within Peru, while U.S. mediation of the Tacna-Arica dispute made war between Peru and Chile unlikely for the foreseeable future. ${ }^{9}$ In short, they concluded, neither concern raised by the solicitor in February seemed likely to develop. Neither the naval mission's wide-ranging powers nor its closeness to the dictator was seen as a significant impediment to the execution of U.S. foreign policy.

Having cast the American lot firmly with the now-entrenched Leguía, and recognizing the naval mission's importance to productive U.S. relations with him, the State Department next sought to extend the naval mission's tenure in Lima beyond its initial twoyear term. In this endeavor it found willing partners in the U.S. Navy's General Board, a panel of senior naval officers formed in 1900 to advise the Secretary of the Navy on naval policy, and in the Office of Naval Intelligence (ONI), which had overseen the activities of the U.S. naval missions in Peru and Brazil since their creation. ${ }^{10}$ ONI Director Luke McNamee (Captain, U.S. Navy) was particularly impressed with the work the naval mission had done throughout its first two years in Peru, and believed the expansion of such missions was important to the success of U.S. policy in Latin America. "The United States should do everything to encourage Latin American Republics to ask for Naval missions," McNamee

\footnotetext{
${ }^{9}$ Citing legislative successes, public approval over his handling of the Tacna-Arica problem, and suppression of the Iquitos Rebellion, Sterling reported to Washington in March 1922 that Leguía had "consolidated his position, especially with business and financial circles" and that he was "now more firmly entrenched than at any period of his incumbency." See Chargé d'Affaires in Lima (Sterling) to Secretary of State, "Report on General Conditions Prevailing in Peru During the Previous Month," March 9, 1922, RG 59, File 823.00/418, National Archives.

${ }^{10}$ Paolo E. Coletta, A Survey of U.S. Naval Affairs, 1865-1917 (Lanham, MD: University Press of America, 1987), 88.
} 
urged the Chief of Naval Operations in March of 1922, "and should send them wherever [they are] requested." ${ }^{\prime 1}$ In stating this case, he made an eloquent argument that the Navy should do more than fulfill its historical role of protecting American interests overseas - it should promote those interests as well. Latin America was where the Navy could most productively do this, he noted, not only because U.S. interests there were significant and governed by a clear, longstanding policy (the Monroe Doctrine), but because in recent years Washington had based its policy there on the forging of a spirit of "Pan-American union" throughout the hemisphere. ${ }^{12}$ This meant, McNamee wrote, that U.S. policy depended to a far greater degree than before on securing the "friendship and confidence of our southern neighbors" - a job for which the Navy was particularly well suited given "the importance of the military in these [Latin American] Republics, where the General or Admiral of today is very apt to be the President of tomorrow." After all, he suggested, it was "only natural" to expect that military and naval men trained by U.S. missions should, when they rose to positions of national leadership in the future, "look with favor on the country under whose tutelage they gained their education." In the long run, he stressed, this "favor" toward the United States would be "reflected in their political, financial and economic relations" and not merely in their military and naval relations. ${ }^{13}$

\footnotetext{
${ }^{11}$ McNamee to Chief of Naval Operations on "Naval Missions to Latin America," March 30, 1922, RG 80, General Board Subject File 438, Box 168, National Archives.

${ }^{12}$ Ibid. On Pan-Americanism in U.S. foreign policy in the early twentieth century, and on its place in Woodrow Wilson's foreign policy, see Mark T. Gilderhus, Pan American Visions: Woodrow Wilson in the Western Hemisphere, 1913-1921 (Tucson: University of Arizona Press, 1986). Gilderhus argues that the preferred U.S. approach to relations with Latin America in the $20^{\text {th }}$ century, Pan Americanism, was the centerpiece of Woodrow Wilson's Latin American policy as well as the basis for the broader foreign policy he pursued in the world after World War I. He notes that Wilson believed the nations of the western hemisphere shared a "natural harmony of interests" and that what was in the best interests of the United States was naturally in the best interests of other nations - an interpretation often shared by Latin Americans in the economic realm but fiercely contested in the political realm.

${ }^{13}$ McNamee to Chief of Naval Operations on "Naval Missions to Latin America," March 30, 1922, RG 80, General Board Subject File 438, Box 168, National Archives.
} 
At the same time they helped foster goodwill toward the United States, McNamee further argued, naval missions throughout Latin America would help advance Washington's post-World War aim of rolling back and replacing European influence in the Americas and paving the way for U.S. supremacy. Indeed, when the Woodrow Wilson administration decided to accede to Leguía's request for a U.S. naval mission in 1920, it did so in large part because it harbored concerns that European powers that had long maintained dominant economic and strategic influence in South America (principally Great Britain) would seek to re-establish themselves there after recovering from the devastation of the recent World War. ${ }^{14}$ The successes the U.S. naval mission had achieved in Peru throughout its first two years had helped to hold this feared development at bay, and importantly, he stressed, had done so on the relative cheap. Indeed, McNamee argued, the great benefit of missions such as the one in Peru was that they furthered American interests and "cost us nothing." Naval missions were therefore "the most potent influence I can think of in fostering close relations with South America," he wrote. They enabled the United States to "neutralize the influence of foreign powers" in Latin America, expand U.S. strategic (and by extension, economic) reach there, and perhaps most importantly, they demonstrated the kind of positive engagement that would keep Latin American nations from seeing in Washington's policy "anything that might be construed...as apathy or as ignorant disregard of our mutual interests." Failure to send U.S. missions, McNamee concluded, would render Pan-American solidarity "nothing but a pious aspiration," and would leave the U.S. interests in a disadvantaged position in the future. ${ }^{15}$

\footnotetext{
${ }^{14}$ Tulchin, The Aftermath of War: World War I and U.S. Policy Toward Latin America, 34-35.

${ }^{15} \mathrm{McNamee}$ to Chief of Naval Operations on "Policy in regard to Instruction of Foreign Naval Officers at home and abroad," April 28, 1922, RG 80, General Board Subject File 438, Box 168, National Archives.
} 
McNamee's two lines of argument resonated with the Navy's General Board, which demonstrated a keen understanding of the diplomatic nature of naval missions' work and, in turn, fully endorsed the expansion of such missions to other Latin American countries. In a letter to Secretary of the Navy Edwin Denby, the Board noted that South America represented one of two "special spheres" in the world (the other being Asia) that the United States was "particularly interested in seeing developed along lines in accord with her general ideas of international policy." In its view, nothing less than "the prestige of the United States" - so important to cultivating international goodwill - was on the line when it came to the question of sending more naval missions to Latin America. The United States should, therefore, not only approve future requests for such missions, the Board advised, but should "in a diplomatic way make it understood that similar requests from South American countries would not be unwelcome." 16 This was especially true of what the Board called South America's "peculiar triangle" of Argentina, Brazil, and Chile (today known as the Southern Cone) - nations which, as historian Mark Gilderhus notes, have leaned politically, economically and culturally more toward Europe than the United States, have long been the "most powerful and influential" in South America, and have acted as counterweights to U.S. influence in Latin America. ${ }^{17}$ "It would be exceedingly undesirable," the General Board concluded, if in these countries "dissimilar [European] sentiments, ideals and methods should be allowed to crop out" and spread throughout the continent. Therefore, the Board

\footnotetext{
${ }^{16}$ General Board (Senior Member Present) to Secretary of the Navy on "Naval Missions to Foreign Countries," April 19, 1922, RG 80, General Board Subject File 438, Box 168, National Archives.

${ }^{17}$ Gilderhus, Pan American Visions: Woodrow Wilson in the Western Hemisphere, 1913-1921, 20-27. On the "ABC" countries and their historical independence from the United States in foreign relations, see Schoultz, Beneath the United States: A History of U.S. Policy Toward Latin America. See also Michael J. Francis, The Limits of Hegemony: United States Relations with Argentina and Chile During World War II, International Studies of the Committee on International Relations, University of Notre Dame (Notre Dame, IN: University of Notre Dame Press, 1977).
} 
recommended, all efforts should be made to send additional naval missions to South America "to forestall any influences which might tend to work against the methods and ideals which we hope to see instituted" there, and to ensure that U.S. "naval sentiment" was positioned to permeate the entire continent. ${ }^{18}$ Given its concern about European influence in the "peculiar triangle" countries, the General Board saw continuing the naval mission to Peru as especially important, as Peru was a nation whose geographic position and extraordinarily pro-U.S. political orientation under Leguía aided in the task. Accordingly, in its final set of recommendations to the Secretary of the Navy, the General Board urged that in addition to encouraging further missions, the Navy should support the renewal of contracts for naval mission members in Peru. ${ }^{19}$ Secretary Denby's approval of the Board's recommendations on May 23, 1922 helped solidify the American naval mission's presence in Peru, and demonstrated that the U.S. Navy foresaw no problems associated with the dual status of the mission's personnel. ${ }^{20}$

On the issue of retaining the naval mission in Peru, the General Board's position was in perfect harmony with that of the State Department. In February 1922 the U.S. Chargé d'Affaires in Lima, Sterling, who was already on record as a strong advocate for supporting Leguía, wrote to Secretary of State Charles Evans Hughes recommending that the contracts of mission members be renewed. "From a political point of view," he wrote, "there is no question but that the presence of the Mission is valuable to the United States." It was

\footnotetext{
${ }^{18}$ General Board (Senior Member Present) to Secretary of the Navy on "Naval Missions to Foreign Countries," April 19, 1922, RG 80, General Board Subject File 438, Box 168, National Archives.

${ }^{19}$ General Board (Senior Member Present) to Secretary of the Navy on "Naval missions to foreign countries. Policy in regard to instruction of foreign naval officers at home and abroad.," May 19, 1922, RG 80, General Board Subject File 438, Box 168, National Archives.

${ }^{20}$ Secretary of the Navy Memorandum for the General Board, May 23, 1922, RG 80, General Board Subject File 438, Box 168, National Archives.
} 
valuable in large part because Leguía was a willing partner who was "most anxious" to have its stay in Peru extended. Moreover, he argued, the mission strengthened the already "very cordial" relations between the United States and Peru and enhanced "American prestige." In an assessment that echoed the analyses of ONI and the Navy's General Board, Sterling pointed not just to the benefits of maintaining the mission, but to the costs: should the mission not be renewed, he noted, "the Peruvian Government would doubtless invite some other foreign Power - probably Great Britain - to replace it." ${ }^{21}$ Just as they did in establishing the mission in 1920, on the issue of extending its tenure the Navy and State Departments exhibited a degree of cooperation that suggests an underlying compatibility of views. To both, the U.S. naval mission to Peru was an important arm of American diplomacy and a critical ingredient to productive relations with Leguía. In July 1922 the contracts of naval mission chief Frank Freyer and Escuela Naval director Charles G. Davy were extended by one and two-and-a-half years, respectively, while arrangements were made to dispatch replacements for personnel being rotated home for assignment elsewhere in the U.S. Navy. ${ }^{22}$

\section{CHALLENGES: THE WOODWARD INCIDENT}

Diplomatic difficulties with the naval mission began to appear only after its initial two-year contracts had been renewed and it experienced this first turnover in personnel. Their emergence is traceable to the fact that, in committing to extend the mission,

\footnotetext{
${ }^{21}$ U.S. Chargé d'Affaires in Lima (Sterling) to Secretary of State, February 20, 1922, RG 59, File 823.30/25, National Archives.

${ }^{22}$ See "Brief Summary," 5. Captain Freyer's contract was extended for one year from July 1, 1922, and Commander Davy's contract was extended two-and-a-half years from July 1, 1922. In October, 1922, Emory D. Stanley (Commander, U.S. Navy) arrived to replace James A. Bull (Commander, U.S. Navy) as the Peruvian Navy's Director of Administration.
} 
Washington confirmed the wisdom of the curious arrangement whereby its naval personnel served as officers in the Peruvian Navy. Continuing the mission gave this arrangement an air of permanence, and made it a durable symbol of Washington's support for Leguía. These developments emboldened the dictator to pursue his long-desired expansion of the Peruvian fleet, just as American banks' growing confidence in Peru made a naval buildup seem more possible than before. As the odds of some sort of Peruvian naval expansion grew in 1923, the State Department began to perceive the challenges that this type of involvement in Peru's sovereign naval affairs could pose for U.S. policy in the region.

Up to that time the State Department had expressed only approval of Leguía's methods and praise of the naval mission's activities on his behalf. But the prospect of a Peruvian naval buildup directed and supervised by American officers acting as agents of Leguía's government gave U.S. foreign policymakers pause. The U.S. legation in Lima expressed fears that Leguía's naval ambitions could destabilize fragile relations between Peru and Chile and disrupt President Warren Harding's nascent efforts to mediate the Tacna-Arica dispute between the two neighbors that had festered since the War of the Pacific (18791884). In February 1923 the U.S. Chargé d'Affaires in Lima, who earlier had made the case for strong American support for Leguía despite his dictatorial ways, warned that in the context of U.S. mediation, even small U.S. naval contracts made with Leguía could be interpreted as hostile by Chile and stoke opposition to U.S. policy in the region. ${ }^{23}$ With this

\footnotetext{
${ }^{23}$ The U.S. Chargé d'Affaires, Frederick Sterling, who had been a major supporter of the naval mission, expressed concern that a contract being contemplated by the U.S. Government for the repair and refurbishing of Peruvian naval vessels at U.S. facilities in the Panama Canal Zone - totaling "four or five hundred thousand dollars" - could "not only create an improper burden on [Peru's] resources" but could prove embarrassing for the United States if efforts to collect from Peru proved difficult." This was a concern, Sterling wrote, "without considering the political aspect of the question and disregarding the possible misinterpretation of the motives of the United States by other South American countries." See U.S. Chargé d'Affaires in Peru to Secretary of State, February 8, 1923, RG 59, File 823.34/62, National Archives.
} 
in mind the State Department pursued a cautious policy aimed at supporting Harding's efforts and finding a workable solution that would lower bilateral tensions between Peru and Chile and bring permanent stability to that troubled border region. ${ }^{24}$ Central to that cautious policy was maintaining a favorable environment in which bilateral discussions could make unimpeded progress. From the State Department's perspective, that seemed to rule out a significant expansion of the Peruvian fleet.

It was in this tense environment that Clark $\mathrm{H}$. Woodward, who took over as the new chief of the U.S. naval mission in July 1923, took his highly public stand in favor of a major enlargement of the Peruvian fleet and, for the first time, clearly demonstrated that U.S. mission members' dual status could significantly complicate U.S. foreign relations. The difficulties began with a public address Woodward gave at a memorial honoring Peru's foremost naval hero, Contraalmirante Miguel Grau Seminario, in Lima's port of Callao on October 27, 1923 - the day celebrated as "Navy Day" in the United States. ${ }^{25}$ Woodward had been instructed by the Navy Department in Washington to render honors to Admiral Grau, whose death aboard the Peruvian ship Huáscar in battle with the Chilean Navy during the War of the Pacific made him a martyr, by laying a wreath at the monument built in the Peruvian officer's honor. Charged with an essentially diplomatic task and acting a representative of the United States, Woodward briefly paid homage to Grau at the beginning of his remarks, calling him an able, energetic, and "brave" naval commander. The majority of his speech, though, was far from routine. In short order, he shifted from praising Grau to

\footnotetext{
${ }^{24}$ Clayton, Peru and the United States: The Condor and the Eagle, 71-73 and 137-41.

${ }^{25}$ The celebration of a "Navy Day" was proposed in 1922 by the U.S. Navy League. Intended to be a day of appreciation for the naval service, it was first observed on the birthday of former U.S. President Theodore Roosevelt, October 27, 1922. See "Nation to Observe Navy Day Friday: Navy League Chooses Birthday of Roosevelt for General Tribute to the Fleet," New York Times, October 23, 1922, 32.
} 
exhorting the gathered crowd to avoid repeating what he saw as the mistakes that made Grau's death such a crushing blow to the nation's fortunes. Wading deeply into the realm of Peruvian naval policy, Woodward shed his ceremonial role representing the United States and seamlessly assumed another role: that of Peru's most senior naval officer. Stepping firmly beyond the bounds of his assignment from Washington, Woodward proceeded to articulate a number of naval preparedness lessons he believed Peru should draw from the War of the Pacific, and made a forceful argument to the gathered crowd that, to avoid a similarly tragic fate in the future, Peru needed to significantly strengthen its naval defenses. ${ }^{26}$

The heart of Woodward's argument at the Grau memorial was that, as the linchpin of Peru's security, the Navy must never again be put in a position where its continued existence as a credible fighting force could be threatened in a single battle. It must be made larger and more capable. Despite the "heroism" Grau exhibited in the War of the Pacific's decisive Battle of Angamos (October 8, 1879), and despite the fact that he had done "all that a mortal could do with the inadequate means" he was provided, Woodward argued, the admiral had been "sacrificed on the altar of his country" by his government's "lack of foresight" and failure to maintain a navy equal to the nation's security challenges. ${ }^{27}$ The outcome of Angamos had given the Chilean Navy command of the sea and had made it possible for Chile to land an invading army on Peruvian soil. That, he continued, made the outcome of the war (Chilean victory) a foregone conclusion. ${ }^{28}$ Moreover it had demonstrated with tragic force

\footnotetext{
${ }^{26}$ Clark H. Woodward, "Homenaje al Contralmirante Grau," Revista de Marina VIII, no. 5 (NoviembreDiciembre 1923): 788 .

${ }^{27}$ Ibid, 789.

${ }^{28}$ At several points in his speech, Woodward noted the strategic significance of the Battle of Angamos. In one particularly articulate passage, he argued that "As a fact set forth by many well known military and naval historians, Peru did not lose the war [of the Pacific] when its army was overwhelmed, but had already lost it when command of the sea passed to the power of the enemy." Ibid, 792.
} 
the truth, for Peru, of the maxim "he who is victorious at sea, is victorious also on land." The present gathering at Grau's memorial, Woodward noted, afforded him the opportunity to "take from the pages of history some of the bitter lessons that should be learned from the sad facts of 1879 , when Peru - owing to its failure to truly prepare - was obligated by her enemy to accept peace because the statesmen of the country had provided only a small navy unable to compete with the enemy."29 Sadly, he continued, even the bitter peace that followed the War of the Pacific could not convince successive Peruvian governments to prepare and maintain adequate naval defenses. In words echoing similar criticisms American officers had of U.S. preparedness, Woodward noted that "as the work of the navy in times of peace is not prominent," public interest in naval affairs has a tendency to decline, permitting "desires of economy take precedent in the mind of the statesman." "Unfortunately," Woodward argued, the economy mindset "manifests itself in a dangerous way: in a policy of poor preparation, and in a reduction of the fleet to a point much lower than that needed to ensure security." The real danger of the peacetime economy mindset, he concluded, was its staying power: absent some national crisis, "little or no interest is taken in naval affairs" until "the clouds of war begin to loom on the horizon., 30

As he would later argue while making his specific recommendations for building up the Peruvian fleet, in his remarks at the Grau monument Woodward made the case that over the long term, ill-preparedness invited greater foreign aggression and proved more costly than a policy of modest, proactive preparation. Fundamentally, he argued, by failing to maintain adequate naval defenses Peru was neglecting the very important fact that, for coastal nations, national power and naval power "march in parallel." Given the nation's vast

\footnotetext{
${ }^{29}$ Ibid, 790.

${ }^{30}$ Ibid, 790 .
} 
coastline and wholesale dependence on the sea for commerce and communications, he stressed, maintaining "a weak navy is only preparation for defeat - a defeat that would mean humiliation and disaster" for Peru. Should it continue maintaining a poor naval establishment, Woodward suggested, Peru would soon learn the very difficult lesson that "national weakness causes more wars than national power." Thus, he urged, the efficiency of the Navy (and, for that matter, the Army) was "not something to be thought of only when war is imminent." And the ability of the naval officer, whose job was to safeguard the nation's security regardless of the Navy's material condition, was extraordinarily limited in this regard. The reality, Woodward concluded, was that in the absence of a change of course, the nation's future battles would be lost long before hostilities commenced: they would be lost by statesmen in the halls of parliament, in the Council of Ministers, or in the various ministries of government where important resource decisions went against the interests of stronger naval defenses. Building a Navy equal to the task of ensuring Peru's security thus placed a special burden on the statesman. ${ }^{31}$

Fully embracing his role as a Peruvian officer, Woodward then proceeded to define what an adequate naval defense for Peru should look like. Its centerpiece, he argued, must be the acquisition of enough capable vessels to deny potential enemies the ability to threaten Peruvian shores, as Chilean naval and ground forces done in the War of the Pacific. ${ }^{32}$ As justification Woodward cited French naval strategist René Daveluy's assessment of Peru's predicament in that war. "If Peru would have been superior at sea," Woodward quoted

\footnotetext{
${ }^{31}$ Ibid, 790-791.

${ }^{32}$ Later, in making his specific recommendations, Woodward would back off of his conclusion that the object of Peru's naval buildup had to be the achievement of command of the sea. At this early stage, however, in October of 1923, he argued that command of the sea was the objective: "El dominio del mar no puede nunca ser alcanzado o mantenido sin buques de guerra" ("Control of the sea can never be achieved or maintained without ships of war.”) Ibid, 793.
} 
Daveluy, "it would have protected its territory without the need of a single soldier." While the nation's "first concern" in the wake of the war "should have been the reorganization of its navy," he further cited Daveluy, in the decades that followed, Peru ignored the causes of its defeat, minimized the Navy, and foolishly dedicated the lion's share of its scarce defense resources to the Peruvian Army. ${ }^{33}$ The implication was that for nearly four decades Peru's national policy had ceded control of the sea to an enemy it still very much feared, and with whom it still had an unresolved border dispute. The solution, which Woodward would spell out in considerable detail later, was the acquisition of vessels capable of securing and maintaining command of the seas - not necessarily "battleships or cruisers of grand power," which Peru could not afford, but "destroyers, submarines, and airplanes which, although small, play a very important role in naval warfare." "If sufficient in number and properly managed," he concluded, "they will be capable of stopping an enemy squadron of much larger, more powerful ships. ${ }^{34}$

Woodward's address, and reaction to it in other South American countries, caused alarm in Washington. After the admiral's remark's began hitting newspapers in Chile and Argentina, Frederick Simpich, a former State Department official working as a writer for the Saturday Evening Post and Colliers, reported to Orme Wilson of the Department's Division of Latin American Affairs that Chilean and Argentine officials had expressed to him "a strong dislike" for naval missions such as the ones the United States maintained in Peru and Brazil. Simpich noted that officials in both countries' Washington, DC embassies recognized that the United States was "within its rights" to send such missions, but that the sight of American officers drawing pay from these Governments created "suspicion and hostility"

\footnotetext{
${ }^{33}$ Ibid, 792.

${ }^{34}$ Ibid, 793.
} 
because the American officers' efforts were "helping to increase the [size and capability of the] navies of the countries," and because those improved navies "might be employed against Chile and Argentina in the future." Moreover, Simpich noted, the officials had singled out Admiral Woodward's Navy Day activities for criticism: his action of laying a wreath on the statue of Admiral Grau had "created a painful impression" in Chile in light of Washington's stance as independent arbitrator of the Tacna-Arica dispute as well as its position as an advocate of "plans and conferences for the limitation of armament[s]" throughout Latin America. ${ }^{35}$ At the same time, another official in the Department's Division of Latin American Affairs cautioned State Department leaders that assistance provided to Peru by the United States through its naval mission would almost invariably "cause much comment in other South American countries," and that "this Government... will be severely criticised therefor [sic.]" because of the mission's activities. ${ }^{36}$

The State Department was taken by surprise because Woodward had crafted his remarks at the Grau monument and his subsequent recommendations for a naval buildup (detailed in Chapter 2) in close consultation with President Leguía and without notifying Washington of his intentions. The fleet expansion he proposed called the purchase of six destroyers, six submarines, and twenty-five military aircraft, as well as for the refurbishment of the remainder of the Peruvian fleet and the construction of new stations ashore. In total, it was a massive buildup given the diminutive stature of the Peruvian fleet at the time. The price tag for all of this, reported to be approximately 6 million Peruvian Pounds, far exceeded the size of the modest proposals Woodward's predecessor had contemplated. The size and

\footnotetext{
${ }^{35}$ Orme Wilson to Francis White (Memorandum of Conversation with Frederick Simpich), February 27, 1924, RG 59, File 839.51/2404, National Archives.

${ }^{36}$ Cox to Francis White, February 28, 1924, RG 59, File 823.34/67, National Archives. The U.S. was singled out for criticism even after it forced Leguía to accept a smaller naval buildup than he had sought.
} 
cost of the Woodward program, in the State Department's view, was unacceptably large and threatened to undermine the impartiality that underlay President Calvin Coolidge's fledgling efforts to mediate the Tacna-Arica dispute. ${ }^{37}$ If Woodward's proposal were enacted, U.S. foreign policymakers feared, other nations of the South America would see the United States - and not just its naval officers in Peru - as proposing a destabilizing expansion of Peru's sea power at a time when Peruvian-Chilean relations begged for caution.

Upon receiving word of Woodward's proposed expansion program, Secretary of State Charles Evans Hughes pinpointed the heart of the diplomatic problem it posed for the United States: such a quantitative and qualitative increase in Peru's Navy, Hughes wrote to Navy Secretary Edwin Denby, could easily be interpreted by the Chilean government as a hostile act by the United States because, even though Woodward made the recommendation in his capacity as a "Peruvian" naval officer, the fact was that he remained a commissioned officer in the United States Navy and continued to draw pay from the American treasury. Foreign governments, he suggested, would not necessarily understand the unique circumstances under which U.S. officers in Peru served the Leguía government. The danger, he concluded, was that if the impetus for a buildup of Peru's Navy appeared to come from the United States, it would undercut nascent U.S. efforts to find an "impartial" solution to the TacnaArica dispute. Not surprisingly, the State Department quickly sought to distance itself and the Coolidge administration from any implication that American policy advocated a destabilizing expansion of the Peruvian Navy. In fact, in attempting to control the damage Secretary Hughes asked the Navy Department to have Woodward abandon any plans for enlarging the Peruvian fleet or, if that proved impossible given his contractual status as an

\footnotetext{
${ }^{37}$ Coolidge assumed the role of mediator upon becoming president following the death of Warren G. Harding on August 2, 1923.
} 
arm of the Peruvian state, that he "at least not to push the matter of increased armaments for Peru. ${ }^{\text {38 }}$ Woodward's deep involvement in Peru's sovereign naval affairs had made him an advocate of a policy, Peruvian naval expansion, that threatened to derail his own nation's interests in solving a persistent, seemingly intractable problem in inter-American affairs. The controversy surrounding the Woodward proposal ended up subsiding when Washington gave its blessing to more modest, "entirely defensive" naval building plans that were designed to meet Leguía's desires while not upsetting the delicate Tacna-Arica situation. However, the episode did cause significant "embarrassment" in Washington, and underscored the unique diplomatic problems that could arise from permitting U.S. naval personnel to serve simultaneously in the U.S. and a foreign naval establishment. ${ }^{39}$

The difficulties that the naval mission's deep involvement in Peru's sovereign naval affairs could cause for U.S. foreign policy came even more sharply into focus in the months that followed. In March of 1925, the U.S. Ambassador to Chile, William Collier, reported that the press in the Chilean capital of Santiago had begun expressing grave concerns about Peru's unfolding naval building plans. A February 24, 1925 article in El Mercurio had noted that Peru's impending purchase of two R-Type submarines from the Electric Boat Company was being received "with a great deal of interest by the public," and suggested that even though Peru professed to be building its fleet "to guard coastwise and international commerce," it seemed likely that the acquisition of submarines with the blessing of the U.S. naval mission was "merely the first step in the unfolding of Peru's plans." The article expressed concern that "the submarines that have been ordered are twice as large as those of

\footnotetext{
${ }^{38}$ Secretary of State to Secretary of the Navy, December 17, 1923, RG 59, File 823.34/64, National Archives, 1 2.

${ }^{39}$ State Department, Division of Latin American Affairs Memorandum on "Naval Armament in Peru," September 23, 1924, RG 59, File 823.34/76, National Archives.
} 
Chile," and that under U.S. tutelage Peru appeared also to be arming a large air force equipped with naval airplanes. In sum, the article noted fearfully, it appeared that Peru had plans to create a fleet "that will make her one of South America's foremost naval powers." A February 27 editorial in the same paper suggested that the only objective of such an aggressive program - one intended to "create an Army and Navy capable of competing with ours" - was "revenge" for Chile's triumph in the War of the Pacific. It went so far as to suggest that Leguía was plotting "a war of revenge" in order to "make Peruvians forget the persecutions that attend the regime of Mr. Leguía." ${ }^{40}$

\section{CHALLENGES: A MILITARY MISSION}

Despite such concerns the United States remained committed to keeping its naval mission in Peru even as it became clear, following the Woodward episode, that overt U.S. military support for Leguía could compromise Washington's broader interests in the region. Triggered in part by Leguía's desire to expand the Peruvian fleet, these concerns were heightened by the dictator's persistent pursuit between 1920 and 1925 of a U.S. military mission to provide his Army with the same kind of direction and assistance that the American naval mission was providing to the Peruvian Navy. He first considered seeking a U.S. military mission while courting the naval mission in 1919 and 1920, but, perhaps recognizing that Washington saw a naval mission as better suited to promoting its interests in the region, opted to take what he could get at the time and revisit the issue of a military mission in the future. $^{41}$

\footnotetext{
${ }^{40}$ U.S. Ambassador to Chile to Secretary of State, March 26, 1925, filed in RG 38, Office of Naval Intelligence, File P-1-c, Box 1212, National Archives.

${ }^{41}$ In early May, 1923, U.S. Ambassador to Peru Miles Poindexter wrote to Secretary of State Charles Evans Hughes that the "Question of an American military mission" had been "considered by president [Leguía] about
} 
Leguía's tenacity in pursuing a U.S. military mission in subsequent years demonstrates very clearly that he was far from a passive recipient of U.S. actions and that, indeed, he intended to play the United States for maximum benefit. In April of 1923, months after the renewal of the naval mission's contracts had cemented U.S. ties to his government, Leguía dispatched his son, Juan, to raise the idea of a U.S. military mission directly with Secretary of State Charles Evans Hughes in Washington. The tack the younger Leguía took in broaching the idea reflects his father's attentive focus on Washington's interests in South America, and specifically, its desire to supplant Europe as the dominant strategic and commercial player on that continent. In his meeting with Hughes, Juan Leguía presented the idea of a military mission for Peru as an opportunity for the United States to continue rolling back European influence in South America. He indicated that his father was contemplating terminating Peru's longstanding French military mission, on the grounds (which Hughes recognized as suspect) that the mission's chief, a figure widely respected in Peru, was engaged in graft against the government. The younger Leguía proceeded to state that his father would "probably remove" the mission chief from command of the Peruvian Army, and then said that in "his own view" Peru's Army, like its Navy, would be better off in the future under the charge of American officers. For his part, in relaying the substance of his conversation with the younger Leguía to U.S. Ambassador Miles Poindexter in Lima, Secretary Hughes advised that from a policy point of view he considered the moment "inopportune" for sending Leguía a military mission because the Tacna-Arica dispute remained unresolved, and because the United States did not want to disturb ongoing Pan-

two years ago but since that time never suggested [it] to Embassy." See U.S. Ambassador to Peru (Poindexter) to Secretary of State (Telegram), May 2, 1923, RG 59, File 823.20/3, National Archives. 
American discussions on limiting military and naval armaments. ${ }^{42}$

Still Leguía persisted. He gauged U.S. willingness again in 1924 in the hope that the glacial progress being made in the U.S.-brokered talks on Tacna-Arica might soften Washington's resistance. ${ }^{43}$ His August 1924 query came to Washington via naval mission member Charles Gordon Davy, the Director of the Escuela Naval (Peruvian Naval Academy), who relayed a message to Ambassador Poindexter with a familiar ring to it: "great dissatisfaction exists [within the Leguía administration] with the French Military Mission," and Leguía would likely seek a new mission "from some other country" when the French contract expired. Sending the request through the U.S. naval mission, whose members were firmly on the inside of the dictator's inner circle, made it clear that, to Leguía, "some other country" was the United States. As it had the year before, though, Washington held firm. Despite some very limited progress in negotiations, a solution on Tacna-Arica remained elusive, and relations between Peru and Chile continued to be strained. Together, this meant that the moment was still inopportune for the United States to comply with Leguía's wishes. As Ambassador Poindexter noted, should the United States comply with Leguía's request, "the junction of both a Naval and a Military Mission from the United States in one country would give a handle that the anti-United States press [in Latin America] would be quick to grasp."

Undaunted, Leguía tried again in late 1925 when the untimely death of the French

\footnotetext{
${ }^{42}$ Secretary of State to U.S. Ambassador to Peru, April 26, 1923, RG 59, File 823.20/2a, National Archives.

${ }^{43}$ The French military mission to Peru is discussed in Chapter 1. Secretary of State to U.S. Embassy in Peru (Telegram), April 26, 1923, RG 59, File 823.20/2a, National Archives. See also U.S. Ambassador to Peru to Secretary of State (Telegram), May 2, 1923, RG 59, File 823.20/3, National Archives. This telegram mentions that Leguia had considered asking for an American military mission at the same time he requested a naval mission in 1920, but that "since that time never suggested [the idea] to [the American] Embassy."

${ }^{44}$ U.S. Ambassador to Peru to Secretary of State, August 27, 1924, RG 59, File 823.20/10, National Archives.
} 
mission chief presented him with an opportunity to again force the issue with Washington. Approaching Poindexter directly in late December, Leguía again stressed that he wanted an American officers to direct and administer Peru's Army. ${ }^{45}$ State Department fears of destabilizing the Tacna-Arica negotiations persisted, however, and continued to weigh against complying with Leguia's request. But the dictator's persistence finally forced the American diplomats to be more forceful in responding. On the one hand, the Washington needed to maintain a happy and compliant Leguía who favored American commercial interests in Peru and who continued to look to the United States for capital and technical expertise. On the other hand, though, it was clear that the United States had to be sensitive to broader regional concerns and could not grant Leguía all that he asked. As Secretary Hughes's response to this Leguía overture demonstrates, from that point forward, the objective became containing him - ensuring he had enough U.S. support to maintain his ardently pro-American leanings, but not so much that he could threaten regional stability. So long as the Tacna-Arica situation remained unresolved, Hughes instructed, it would remain "impossible" to send a military mission to Peru. But rather than risk alienating a firm ally even further with such an outright denial, the Secretary noted, the ambassador should only explain to Leguía that the 1920 law that had authorized naval missions for Latin America in the first place had covered only naval personnel and did not specifically authorize sending personnel from other military services. ${ }^{46}$ By taking this approach, Hughes believed, the

\footnotetext{
${ }^{45}$ U.S. Ambassador to Peru to Secretary of State (Telegram), December 26, 1925, RG 59, File 823.20/18, National Archives.

${ }^{46}$ For Hughes' instructions to Ambassador Poindexter, see Secretary of State to U.S. Ambassador to Peru, December 30, 1925, RG 59, File 823.20/18, National Archives. The 1920 legislation authorizing naval missions to Latin America, in specific terms, gave the President of the United States authorization "to detail officers of the United States naval service to assist the Governments of the Republics of South America in naval matters." It did not specifically authorize missions of personnel from the Army or Marine Corps. See Public Law No. 272, 66th Congress, reproduced in Brief Summary, 20.
} 
United States could stall the issue further, keeping Leguía in the pro-American fold while protecting its impartiality before the world as arbitrator of the Peruvian-Chilean border dispute.

Containing Leguía's ambitions became more of a challenge after the U.S. Congress passed, and President Calvin Coolidge signed, legislation in May 1926 authorizing the sending of U.S. Army and Marine Corps personnel to military missions abroad. This action removed what had become the State Department's key public justification for not sending Leguía a military mission. Because the real, underlying reason (Tacna-Arica) for not sending a mission remained, when newspapers in Lima began reporting the U.S. Congressional action, Secretary of State Frank Kellogg instructed Ambassador Poindexter to simply dodge the issue should Leguía continue to push. "Please endeavor if possible to avoid the subject at the present time," he advised, adding that "should President Leguia again bring up the question you may express appreciation and readiness to inquire again regarding the Department's attitude."47 Washington continued to defer, neither sending Leguia a military mission nor clearly denying him one, until, in May 1927, the Peruvian president called the American bluff and appointed a German officer, William Faupel, as Chief of Staff of the Peruvian Army. ${ }^{48}$ The move demonstrated yet again that, while he had strong pro-American leanings, Leguía was willing to act independently of Washington when it suited his needs. And while the move reawakened some U.S. worries about European influence in Peru ${ }^{49}$, they

\footnotetext{
${ }^{47}$ Secretary of State to U.S. Ambassador to Peru, July 17, 1926, RG 59, File 823.20/19, National Archives.

${ }^{48}$ For the passage of a law by Congress permitting the detail of U.S. Army and Marine Corps officers to Latin American governments, see Secretary of State (Acting) to U.S. Ambassador to Peru, July 21, 1926, RG 59, File 823.20/19, National Archives. For Leguia's appointment of German General Wilhelm Faupel as Inspector General of the Peruvian Army, see U.S. Ambassador to Peru to Secretary of State, April 18, 1927, RG 59, File 823.20/23, National Archives.

${ }^{49}$ In recounting Faupel's appointment to the Secretary of State, Ambassador Poindexter wrote that "Much surprise is expressed [in Peru] at the apparent indifference of the United States to the opportunity which was
} 
did not outweigh concerns about possibly enflaming tensions between Peru and Chile over their still-disputed border. Moreover, U.S. officials were not overly concerned in the 1920s with German military influence in Peru. ${ }^{50}$ Managing Leguía's ambitions while the delicate negotiations over Tacna-Arica progressed was a higher priority into 1927 than trying to counteract German influence over Peru's Army. In the end, only when the Tacna-Arica question was settled, in 1929, did Washington seriously entertain sending Leguia the U.S. Army advisers he had desperately wanted for most of the decade.

As Leguía’s push for a military mission in the early 1920s demonstrates, even as he sought closer ties with the United States, the dictator grew quite adept at challenging Washington when he believed it would help him achieve his goals. The U.S. naval mission's presence was a source of strength that helped make this growing assertiveness possible. First, by 1925 it was clear that the mission had developed into a source of secure, predictable support for Leguía and that the United States had no interest in removing it. Despite the diplomatic headaches caused by Admiral Woodward's recommendations, and despite the fact that they had to constantly parry Leguía's numerous attempts to secure a military mission,

offered them [to send a military mission]. The appointment of a German head of the Army and the additional German officers which it implies, is expected to lead to the purchase of a large proportion of the Peruvian military supplies of all kinds from German dealers. This is an important element in the foreign business of the country and it may be expected that the enterprising German merchants will take full advantage of it...In one stroke it has done more than anything that has occurred since the war to advance and enhance the standing of Germans and of Germany in this Latin-American country. It is looked upon as correspondingly a lost opportunity for America." See U.S. Ambassador to Peru to Secretary of State, April 18, 1927, RG 59, File 823.20/23, National Archives.

${ }^{50}$ In reply to Poindexter's concern that Faupel's appointment represented a lost opportunity for the United States, Assistant Secretary of State Francis White wrote "your despatch would of itself give the impression that the failure of this Government to meet the Peruvian Government's wish for the services of an American Army officer was due to mere lack of attention, whereas such was not the case. In order to keep the record clear, therefore, the Department desires to point out that...as long as the Tacna Arica controversy remained unsettled this Government could not possibly accede to President Leguia's request. The Department appreciates the action of the Peruvian authorities in not filling the position until it became necessary to do so, and keenly regrets that the circumstances were not such as to permit the selection of an American officer. The incident is now closed, however, and any explanations would obviously be inappropriate at this time." See Assistant Secretary of State to U.S. Ambassador to Peru (Confidential), May 10, 1927, RG 59, File 823.20/23, National Archives. 
American foreign policymakers continued to perceive enough value in the naval mission to render its withdrawal highly unlikely. Throughout 1924, 1925, and 1926, even as they recognized the nature of Leguía's strengthening dictatorship, U.S. diplomats continued to advocate closer relations in light of growing American interests in Peru and throughout the region. At the same time, they wrote to Washington with nothing but consistent praise for the mission's work, calling it a source of prestige for the United States and a vehicle for developing closer, more cooperative relations with Peru. ${ }^{51}$ Second, even though Washington developed concerns about its officers' dual status, and came to insist on amending their contracts to protect them from involvement in potential Peruvian wars, by the contracts they signed with Leguía's government the mission's officers did become integral parts of the Peruvian Navy and incurred certain obligations to Leguía as commander-in-chief. As Chief of the General Staff, for example, the U.S. mission chief attended weekly meetings (recuerdos) with the president on naval affairs to which the civilian Minister of Marine was not privy. ${ }^{52}$ And from very early on, seldom did Leguía attend high-profile public events without a member of the naval mission close by. ${ }^{53}$ As historian Lawrence Clayton notes, by virtue of Leguía's interest in naval affairs and their placement at the top of the Peruvian Navy, U.S. naval mission members enjoyed "extraordinary access to power.",54 By ensuring close, continuing contact between Leguía and the officers of the

\footnotetext{
${ }^{51}$ For example, in January of 1926, U.S. Ambassador Miles Poindexter wrote to the Secretary of State praising the naval mission's work. Captain Davy's efforts at the Escuela Naval, and Woodward's efforts to "render the [Peruvian] Navy independent of political pressures," were particularly noteworthy. And importantly, by 1925 it had delivered some significant successes: admissions and retention standards at the Escuela Naval had improved considerably, and the first two submarines of Leguía's scaled-back naval expansion program were under construction. See U.S. Ambassador to Peru to Secretary of State, January 25, 1926, RG 59, File 823.323/1, National Archives.

${ }^{52}$ See Brief Summary, 14.

${ }^{53}$ Cite.

${ }^{54}$ Clayton, Peru and the United States: The Condor and the Eagle, 128.
} 
American mission, these meetings gave weight to the Peruvian half of mission members' dual status and, over time, helped the dictator draw the mission into his inner circle and give it an importance out of proportion to its mandated functions of ensuring the "proper organization of the Peruvian Navy" and the instructing and training its personnel. ${ }^{55}$ Evidence of this closeness appeared as early as 1923, when, at Leguía's personal request, the first chief of the mission, Frank B. Freyer (Captain, U.S. Navy), embarked on a tour of southern Peru with the purely propagandistic mission of drumming up public support for the government's naval plans. As reported by La Prensa, the Lima daily taken over by the Leguía government in 1921, Freyer traveled to the mountain cities of Cuzco, Puno, and Arequipa - inland from Peru's lengthy coastline and high in the Andes mountains - to "awaken the interest of the youths of the mountainous regions in affairs of the sea and of the Navy." The idea driving the trip, Freyer argued to the assembled crowds, was that "the Navy should not be considered as a luxury belonging only to rich countries," but rather should be recognized as an indispensible contributor to the whole nation's security. The subtext of Freyer's public remarks was that all Peruvians, whether they lived near the coast, high in the Andes, or in Peru's eastern rainforest region, had a stake in the development of strengthened naval defenses. In each city he spoke to crowds on Leguía's rationale for a strong Navy, and supplemented his presentations with (as La Prensa reported) "the portentous invention of moving pictures" depicting U.S. Navy vessels at sea - a stroke that was no doubt intended to wow the locals while presenting "vividly to the men of the great Andean altitudes the problem of national defense" as Leguía saw it. ${ }^{56}$ For his mission Freyer garnered the praise

\footnotetext{
${ }^{55}$ See description of naval mission duties included in Secretary of State to U.S. Chargé d'Affaires in Lima (Sterling), September 23, 1924, RG 59, File 823.30/24, National Archives.

${ }^{56}$ U.S. Chargé d'Affaires in Peru to Secretary of State, February 21, 1923, RG 59, File 823.30/29, National Archives.
} 
of his own government (U.S. Chargé Sterling noted he showed "both ability and tact" and "added to the prestige of our country") and the thanks of his Peruvian commander-in-chief. Upon completing his stint as naval mission chief later that year, Leguía bestowed upon Freyer the rank of Rear Admiral in the Peruvian Navy and lauded him as a credit to the institution. $^{57}$

\section{CHALLENGES: HAROLD GROW}

The officer who did the most to strengthen Leguía's ties to the naval mission - and whose relationship with the dictator did the most to complicate U.S. foreign policy - was Harold B. Grow (Commander, U.S. Navy), who arrived in Lima in January of 1924 in response to Leguía's request for an officer to lead Peru's nascent naval aviation service. As he embarked on his duties, beginning with the establishment of the naval aviation school at Ancón, Grow very quickly developed a strong rapport with Leguía and became one of the dictator's most trusted advisers. A contributing factor to their personal and professional closeness was the fact that the two men had similar visions of aviation's place both in Peru's national defense and its economic development. Within the realm of national defense, Grow's vision for aviation aligned with Leguía’s plans to rebuild Peru's Navy around submarines and aircraft, the latter of which the president deemed "necessary for the national defense" in an address to the Peruvian Congress in October of $1924{ }^{58}$ Shortly after arriving in Lima, Grow, who had helped establish the U.S. Navy's new Bureau of Aeronautics immediately prior to his assignment to the naval mission in Peru, went on record arguing that

\footnotetext{
${ }^{57}$ Cite.

58 “Mensaje que el señor Presidente de la República leyó ante el Congreso Nacional el 12 de Octubre del presente año," Revista de Marina IX, no. 5 (Septiembre y Octubre 1924): 627. The importance of submarines and naval aircraft to Leguía's naval plans is discussed further in Chapter 2.
} 
aircraft had an "integral" role to play in the nation's future naval defenses. ${ }^{59}$ In 1925 he amplified his argument in the pages of the Revista de Marina, calling airpower "uniquely and exceptionally applicable" to Peru's peculiar national defense challenges because aircraft could "most rapidly help to overcome the existing deficiency in the [nation's] naval defense forces, with a minimum expenditure of money." Moreover, he argued in terms wholly consistent with Leguía's view of Peruvian national defense, superiority in aircraft "might mean the saving of the country" in war while the lack of a naval aviation capability "would most surely spell defeat to a country inferior in other branches" of armed power. ${ }^{60}$

Grow's views comported with Leguía's in the realm of civil aviation as well. Leguía had made overcoming Peru's difficult geography and uniting its distinct regions (the costa, sierra, and selva) into a coherent, traversable whole a priority of his Patria Nueva program of economic development. Throughout his Oncenio, for example, he directed a near-doubling of the national road system (from 10,643 kilometers in 1926 to 19,465 in 1930), which historian Peter Klarén notes improved communications, helped the government "expand its reach into remote areas and extend its authority as never before," and significantly increased the flow of trade and commerce to the nation's remote interior. ${ }^{61}$ Grow saw the naval aviation service as a complement to Leguía's effort to knit the country together. Eventually,

\footnotetext{
${ }^{59}$ A biographical sketch of Grow's life is contained in Appendix A of Sharon S. Pope, "Harold B. Grow and the Establishment of Aviation in Peru, 1924-1930" (University of West Florida, 1973). For Grow's early statements on aviation's role in Peru's naval defenses, see Harold B. Grow, "Empleo táctico de la Aviación Naval," Revista de Marina IX, no. 3 (Mayo y Junio 1924): 155.

${ }^{60}$ Harold B. Grow, "La Aviación es la Nueva Arma de la Marina," Revista de Marina X, no. 4 (Julio y Agosto 1925): 442-443. Grow's original type-written copy of this article (entitled "Aviation, The New Arm of the Navy"), written in English on Servicio de Hidro-Aviación de la Marina letterhead, can be found in Box of the Harold B. Grow Papers, held by the National Naval Aviation Museum, Pensacola, Florida.

${ }^{61}$ Much of Leguía's progress in expanding the national road system was due to a law he championed called the Conscripción Vial ("Road Conscription"), which Klarén notes "required all men aged eighteen to sixty to work six to twelve days each year on the national road system." Klarén, Peru: Society and Nationhood in the Andes, $250-51$.
} 
he imagined, it would be a seedbed from which a broader national aviation program could grow - one that would forge permanent links across Peru's geographical barriers and permit free flows of trade, commerce, and communication throughout the nation. From his earliest days in Peru, Grow hung a map of the country in his office at the naval aviation school in Ancón which labeled much of its interior as "unknown" or "unexplored," something he later said hung "like a burden" over his head. ${ }^{62}$ Early on he resolved to address the problem by proposing the establishment of a network of air routes that would carry mail, trade, and passengers from Lima over the high peaks of the Andes into the nation's interior. The city he identified as the air route's eastern terminus, the city of Iquitos, was an important Amazon River port that, once fully integrated into the nation's economy, could significantly enhance Peru's international trade prospects. It was an idea that met with Leguía's immediate approval. Concerned about Peru's unsettled borders and anxious to break the bonds of commercial and cultural interaction that bound many of eastern Peru's peoples to populations in neighboring countries, the dictator shared Grow's optimism about the potential of air routes to enhance Peru's security and economic prospects, and authorized funds so preliminary work could begin.

With the president's backing, in September 1926 Grow set out with a small party on an overland roundtrip to survey the terrain and climatic conditions with which future air linkages would have to contend, as well as to identify possible locations for air stations and landing fields between Lima and Iquitos. The journey followed the same treacherous path that intra-Peruvian trade and mail delivery routinely had to confront. The group started out from Lima on the Central Railroad of Peru for the interior city of Oroya, then proceeded the next day via automobile to La Merced before hiring a mule train and spending eight long

\footnotetext{
${ }^{62}$ Quoted in Pope, "Harold B. Grow and the Establishment of Aviation in Peru, 1924-1930," 23.
} 
days traversing trails only wide enough for single-file passage while contending with torrential rains, abundant mosquitoes and "insects of all shapes and sizes." Upon arriving at the head of the Pichis River, Grow's group then hired canoes piloted by indigenous guides for a three-day journey to Puerto Bermudas, where they boarded the naval gunboat Napo, which carried them the rest of the way to Iquitos. The return trip to Lima took longer - thirty days - due to difficulty crossing rivers that ran high with the Peruvian spring. In total, the difficult journey to Iquitos and back took fifty-four days to complete. Along the way, Grow selected sites for the three air stations (San Ramon in the Chanchamayo Valley, Masisea on the Ucayali River, and Iquitos) that would anchor the air link. He also selected the aircraft he believed best suited to takeoffs and landings on the kinds of short runways that would be built both in the mountains and in the thickly-vegetated Amazon basin, and settled on a preliminary four-stage transportation plan on which the project could proceed. Grow's design envisioned that when the route between Lima and Iquitos was fully operational, passengers, mail, and commerce would travel from Lima to Oroyo by rail, from Oroya to San Ramon via automobile, and would fly from San Ramon to Masisea before continuing by air to Iquitos. The total journey, which had ranged on average between twenty and thirty days over land in each direction, would be cut to three days. ${ }^{63}$ By 1928 the groundwork had been laid and flights between San Ramon and Iquitos were beginning to occur with increasing regularity. In January of that year, with Leguía's backing, Grow established a governmentsupported airline, La Linea Aérea Nacional al Oriente, and by 1929 the air link between the costa and the selva ran routinely enough that the government considered expanding similar

\footnotetext{
${ }^{63}$ This description of Grow's preliminary work in establishing the Lima-Iquitos air linkage is based on the superb work of Sharon S. Pope, whose M.A. thesis was written with the benefit of numerous, wide-ranging first-person interviews with Commander Grow before his death, as well as access to his private papers documenting his time in Peru. See Pope, "Harold B. Grow and the Establishment of Aviation in Peru, 1924$1930, " 22-32$.
} 
routes to other cities in Peru's eastern interior.

Grow's achievements in building the Lima-Iquitos air link impressed Leguía and distinguished the officer as someone with strong organizational and administrative skills who could quickly deliver positive results. Those results, on top of the success he had had in building the naval aviation school at Ancón (discussed in Chapter 2), strengthened Grow's influence over Peruvian aviation matters and helped deepen his personal and professional relationship with the president. ${ }^{64}$ In December of 1926 this growing closeness took on an official flavor when Grow signed a five-year contract with the Peruvian government and accepted de facto supervision of all aviation in Peru - civil as well as military and naval. ${ }^{65}$ By design it was a longer contract than the typical two- to three-year agreements signed by other members of the naval mission. As Sharon Pope notes, Leguía did not want his aviation priorities to fall victim to turnovers in personnel. ${ }^{66}$ Consequently, along with the position came direct access to power and an extraordinarily high profile.

Expecting that supervision of Peru's fledgling aviation establishment would require his undivided attention, and cognizant of the fact that U.S. Navy authorities were unlikely to permit him to extend his tour in Peru beyond early 1927, Grow chose to accepted Leguía’s offer to remain. He resigned his commission in the active duty U.S. Navy and opted for a

\footnotetext{
${ }^{64}$ Clayton, Peru and the United States: The Condor and the Eagle, 129. Sharon Pope notes that in his first two years in Peru, Grow had established "a viable, continuous aviation program" and had succeeded in large part by "cultivating rapport with President Leguía." She further notes that by late 1926 Grow had "obtained complete authority and control over every aspect of the naval aviation program including the budget." See Pope, "Harold B. Grow and the Establishment of Aviation in Peru, 1924-1930," 20.

${ }^{65}$ Sharon Pope notes that "Until 1928 three official commands for aviation existed [in Peru]: army aviation under the Ministry of War with its center at Jorge Chávez, directed by the German mission; naval aviation under the Ministry of the Navy at Ancón, San Ramon, and Iquitos, guided by the United States naval mission; and commercial and civil aviation directed by an officer of the army." As a practical matter, however, she notes that "Grow's position in Peru and rapport with President Leguía became of greater value to the United States" by the mid-1920s because "he could act as an intermediator [sic.]" between Leguía and U.S. interests in Peru. Ibid, 36, 39.

${ }^{66}$ Ibid, 41.
} 
commission in the U.S. Naval Reserve. While regular naval mission members drew salaries from the U.S. Navy as well as the Peruvian treasury, Grow's new reserve status came with no American pay. The practical effect was that in both institutional and financial terms, he would have the freedom to remain in Peru and serve Leguía indefinitely. ${ }^{67}$ In making this choice, Grow stepped beyond the difficult balance that other members of the naval mission had struck between carrying out their obligations as Peruvian officers while taking care not to entangle themselves too deeply in Peru's sovereign affairs. His contract ensured that he would be working directly for Leguía and, although he would remain a member of the naval mission in name, it also virtually guaranteed that his work would proceed outside established channels. ${ }^{68}$ Comfortable with Leguía and accustomed to unfettered access, it was a modus operandi that Grow immediately embraced. In 1927 he urged Leguía to create a single bureaucracy that would consolidate his control over all aviation within Peru. Such an agency, he argued, would make management of money, equipment and personnel more efficient. Moreover, it would permit the purchase of standardized equipment, and would enable better coordination of training efforts. Quickly persuaded, Leguía presented a bill drafted by Grow to the Peruvian congress, which approved it in February of 1928. Grow's appointment as the new agency's head - to the post of Director General of Aviation - was a foregone conclusion. ${ }^{69}$

As Director General of Aviation, Grow's proximity to power enabled him to directly advance American interests while laboring for Leguía's priorities. He was sensitive, for

\footnotetext{
${ }^{67}$ Ibid, 41-42. Also, See "Brief Summary," 12.

${ }^{68}$ Sharon Pope notes that "Although by the terms of the contract Grow was still attached to the naval mission and would receive any necessary evaluation and discipline through that agency, he was basically autonomous and enjoyed a position of power and authority." Ibid, 42.

${ }^{69}$ Ibid, 40.
} 
example, to the interests of American airplane manufacturers and keen to prevent non-U.S.

firms from making significant inroads into the Peruvian market, stipulating that the government-backed airline he had established would fly only American-made planes. ${ }^{70} \mathrm{He}$ continued to push for acquisitions of U.S. planes even after Peru began suffering severe effects of the Great Depression, signing a contract with the United Aircraft Corporation for twenty-six naval aircraft in January $1930 .^{71}$ More significant than his commitment to acquiring American-built aircraft, however, were his efforts to preserve an advantage for U.S. airlines seeking entry into the Peruvian market. As discussed in Chapter 2, in early 1928 Grow paved the way for Pan American Airways to win the Leguía administration's concession to establish an air mail, cargo, and passenger service between the United States and Peru. When that line began operating in May of 1929, it reduced transit time for communications between the two countries from weeks to a matter of days. ${ }^{72}$ The speed with which Pan-American's work on the U.S. air mail route progressed convinced Grow that the airline would soon be poised to expand its operations from Peru to other South American nations. Accordingly, in late 1928 he prevailed upon Leguía (who had been poised to approve it) to deny a concession to the French firm Aeropostale for the creation of an air link

\footnotetext{
${ }^{70}$ Pope, "Harold B. Grow and the Establishment of Aviation in Peru, 1924-1930," 43.

${ }^{71}$ Leguía had sought to purchase "new airplanes of American manufacture" in September of 1929, before the October stock market crash sent the international financial system into a panic. But, concerned about Peru's high levels of indebtedness, a number of New York banks declined to finance the purchase. This caused Leguía to approach the British firm Vickers, a move that Grow vigorously opposed. In the end, largely because of Grow's efforts to secure financing from an American firm, Leguía signed a contract with the United Aircraft Corporation. See Head of Naval Mission to Peru to Director of Naval Intelligence, September 30, 1929; Head of Naval Mission to Peru to Director of Naval Intelligence, October 31, 1929; and Head of Naval Mission to Peru to Director of Naval Intelligence, January 31, 1929 - all filed in RG 38, Entry E-194, Box 1, National Archives.

${ }^{72}$ U.S. Ambassador to Peru Harold Moore sent a letter (dated May 3, 1929) to President Herbert Hoover aboard the first air mail flight from Peru to New York. Hoover's reply, dated May 17th, noted that "I have your letter of May 3rd which arrived here on the 16th - a matter of thirteen days. I have no doubt that in time this service will be speeded up." See U.S. Ambassador to Peru (Moore) to Herbert Hoover, May 3, 1929 and Herbert Hoover to U.S. Ambassador to Peru (Moore), May 17, 1929, both in President's Personal File, Box 996, Herbert Hoover Presidential Library, West Branch, IA.
} 
between Iquitos and the northern Brazilian state of Pará. ${ }^{73}$ And in early 1929 Grow’s continued lobbying against allowing non-American airlines into Peru caused Leguía to disapprove a proposal by the Colombian-German airline SCADTA (Sociedad ColomboAlemana de Transportes Aéreos) to service select cities in northern Peru. ${ }^{74}$

\section{SUPPORTING DICTATORSHIP}

While it cleared the way for American supremacy in Peruvian aviation, Grow's work also complemented ever-increasing levels of U.S. investment in Peru, advanced Leguía's Patria Nueva agenda, and contributed to growth in the Peruvian economy. ${ }^{75}$ At the same time, it undeniably facilitated more intimate U.S. ties with Leguía, and, by extension, helped strengthen the dictator's hold on power. Their close relationship portended a broader pattern developing in U.S.-Latin American relations. As Grow intensified his relationship with Leguía, U.S. hemispheric policy began undergoing something of a sea change. In the face of increasingly vocal opposition throughout the hemisphere, Washington began in the late 1920s to back away from its longstanding dependence on armed interventionism as a tool of its relations Latin American nations. ${ }^{76}$ Little more than a month after assuming the American

\footnotetext{
${ }^{73}$ Pope, "Harold B. Grow and the Establishment of Aviation in Peru, 1924-1930," 51-52.

${ }^{74}$ For Leguía's decision, see Head of Mission to Director of Naval Intelligence, April 1, 1929, RG 38, Entry 48A, Box 4, National Archives. As David Bushnell notes, SCADTA was established at Barranquilla, Colombia in 1919 by a Colombian-German-Austrian group to fill "a critical need in a country...where topography was highly unfavorable to land transportation." In 1931, Pan American acquired a majority stake in SCADTA, although its name remained unchanged. See David Bushnell, Eduardo Santos and the Good Neighbor, 1938-1942, Latin American Monographs (Gainesville: University of Florida Press, 1967), 18-23.

${ }^{75}$ For more on this, see Klarén, Peru: Society and Nationhood in the Andes, 262-67.

${ }^{76}$ Although the "Good Neighbor Policy" would find its most articulate spokesperson (and its enduring brand name) under the administration of President Franklin D. Roosevelt, the policy's basic non-interventionist contours emerged in the late 1920s under Roosevelt's immediate predecessor, Herbert Hoover. As historian Brian Loveman notes, as president Hoover "sought to extricate the country from the remaining military occupations and the obligations incurred under the protectorate regimes." Hoover's approach to Latin America, Loveman suggests, represented "a genuine change in tactics, a distancing from military intervention and occupation as a principal instrument for achieving U.S. objectives." See Loveman, No Higher Law: American
} 
presidency, Herbert Hoover, who had held the chairmanship of the Inter-American High Commission while serving as President Calvin Coolidge's Secretary of Commerce, made his opposition to U.S. interventionism in Latin America clear. In an April 1929 address to the Gridiron Club of Washington, the new U.S. president declared that it "ought not be the policy of the United States to intervene by force to secure or maintain contracts between our citizens and foreign states or their citizens." ${ }^{, 77}$ Later that year he stressed in an address to the U.S. Congress that, although U.S. Marines remained on long-term occupation duty in Nicaragua and Haiti, in the future the United States did "not wish to be represented abroad in such manner." ${ }^{, 78}$ To end those interventions, and to render similar actions unnecessary in the future, Washington would need to find other means of maintaining stability in the region. The formula that eventually came to characterize the non-interventionist "good neighbor" approach consisted principally of lending political, material, and monetary support to Latin American leaders that Washington saw as capable of maintaining that much-desired stability. ${ }^{79}$ It was precisely the kind of relationship the United States had been developing with Leguía since 1919, a relationship to which the naval mission had been indispensable. By the time Hoover's Latin America policy began to take shape, the U.S. State Department had spent nearly a decade recognizing the dictatorial nature of Leguía's regime. However, because the dictator favored U.S. interests and demonstrated an ability to shield them from

Foreign Policy and the Western Hemisphere Since 1776, 240. For a more detailed examination of Hoover's Latin America policy, see Alexander DeConde, Herbert Hoover's Latin-American Policy (New York,: Octagon Books, 1970).

${ }^{77}$ National Archives and Records Administration, "Public Papers of the Presidents of the United States: Herbert Hoover," (Washington, DC: U.S. Government Printing Office, 1974), 35.

${ }^{78}$ Ibid., 295.

${ }^{79}$ For more on this, see Roorda, The Dictator Next Door: The Good Neighbor Policy and the Trujillo Regime in the Dominican Republic, 1930-1945. See also Schoultz, Beneath the United States: A History of U.S. Policy Toward Latin America, 290-315. 
harm with an iron-handed political stability, it offered him increasing levels of U.S. support.

In this way, the American relationship with Leguía represents a trial run for good neighborism.

When Hoover made his landmark seven-week "goodwill tour" of Latin America as president-elect between November of 1928 and January of 1929, the State Department adviser assigned to brief him on Peru prior to his arrival there, G. Butler Sherwell, gave this emerging reality clear expression. In a background memorandum for Hoover he noted that Leguía exercised "practically autocratic power" within Peru, and acknowledged that elections there were "free only in theory." He further wrote that the Peruvian Supreme Court was "nothing more than an instrument for his [Leguía's] wishes" while Peru's prisons were "known to be filled with political prisoners" who had opposed Leguía. Only token opposition to Leguía could be said to exist within the Peruvian political establishment. Peru's national Congress was packed with pro-Leguía deputies who made it their business to "pass any measure upon which he insists," Sherwell continued, while locally, the prefects of Peru's provinces were "personally appointed by the President and are responsible to him." These transgressions were acceptable, he wrote, because it was clear to the State Department - as it had been to American diplomats very early on ${ }^{80}$ - that Leguía was "a man of great energy, ability and vision" whose close economic and political ties to the United States were “one of his main points of support." In pointing out Leguía's simultaneous dependency on repressive rule and American friendship, the State Department acknowledged that embedded within his rule were the seeds of its own possible demise. Moreover, the State Department

\footnotetext{
${ }^{80}$ As noted in Chapter 1, very early in Leguía's tenure the lead U.S. diplomat in Peru had concluded that "during its present state of civilization" Peru was best served "by an honest and progressive, if autocratic, administration" such as Leguía's. See U.S. Chargé d'Affaires in Peru to Secretary of State (Confidential), November 29, 1921, RG 84, Vol. 182, National Archives.
} 
perceived that the United States had a stake in keeping those seeds from germinating and growing: Leguía could not afford to have "the existence or efficiency of that friendship [with the United States] called into question," Sherwell concluded. As long as his relationship with Washington and New York bankers remained strong, Sherwell cautioned Hoover, Peru could continue to finance its massive program of public works improvements and achieve the economic gains the dictator needed to continue diverting Peruvians' attention away from the state of their nation's internal politics and "the lamentable state" of their government's services. Absent Washington's support, the State Department signaled, Leguía's days could be numbered. ${ }^{81}$

As Leguía's Director General of Aviation, Grow's proximity to the center of power made him an important asset in lending Leguía the strong measure of U.S. support he needed. At the same time, however, this access, and the wide-ranging powers he wielded over the aviation establishment, blurred the established lines of authority that had governed the naval mission's activities since its earliest days. Upon Grow's appointment as head of all aviation in Peru, naval mission chief A.G. Howe stressed to Washington that "it was distinctly understood that it [Grow's appointment] should not in any way interfere with the fact" that Grow remained a member of the Naval Mission and, as such, subject to the orders and jurisdiction of the Head of the Mission. ${ }^{82}$ As Grow accumulated more power and influence with Leguía, Howe sensed that his own position of influence with the president was beginning to wane. He subsequently sought clarification from ONI that, even though Grow occupied a new position with broad national responsibilities within Peru, the Inspector

\footnotetext{
${ }^{81}$ G. Butler Sherwell to Herbert Hoover, "Memorandum on Peru," undated, Campaign and Transition File (Latin America Goodwill Tour), Box 170, Herbert Hoover Presidential Library, West Branch, Iowa.

${ }^{82}$ Head of Naval Mission (Howe) to ONI, on "Duty and work of Naval Mission in Peru," October 10, 1928, RG 38, Entry 48-A (Pan-American Affairs Division), Box 4, National Archives.
} 
General of Aviation was still "a member of the Naval Mission and, as such, one of my subordinates.. ${ }^{, 3}$ But there was little that Washington could say or do to alter the reality on the ground. Having resigned his active duty commission in the U.S. Navy and signed a contract directly with Leguía, Grow was an independent operator, come what may.

\section{THE END OF THE ONCENIO}

Developments throughout 1929 and 1930 exposed just how serious a challenge Grow's close relationship with Leguía - and his deep involvement in Peru's sovereign affairs - posed for U.S. foreign policy. The crash of the U.S. stock market in October 1929, and the precipitous decline of the world economy in the months that followed, wreaked havoc in Peru and strained Leguía's close relationship with the United States. It directly threatened the foundation of his political strength. ${ }^{84}$ For more than ten years Leguía had courted favor with politicians in Washington and bankers in New York, efforts which paid off handsomely as American firms injected tens of millions of dollars in American capital into Peruvian industry and infrastructure projects. That massive, sustained infusion of U.S. capital had

\footnotetext{
${ }^{83}$ Head of Naval Mission (Howe) to ONI, on “Operations, February, 1929," March 5, 1929, RG 38, Entry 48-A (Pan-American Affairs Division), Box 4, National Archives. On February 8, 1929, naval mission chief Alfred G. Howe wrote to U.S. Ambassador Alexander Moore to further clarify Grow's status, and to underscore that he did in fact remain a member of the naval mission. He noted that "the fifth clause of his contract states that Captain Grow has the same rights to diplomatic privileges as the other members of the Naval Mission," while the ninth clause "gives the Head of the U.S. Naval Mission the duty and right to determine any violation of contract and to take any necessary disciplinary action in the case of Captain Grow." Finally, Howe noted, by the eleventh clause of his contract Grow, like the naval mission's other members, was "not obliged to take part in any foreign or civil war in which Peru is engaged." See U.S. Ambassador to Peru (Moore) to Secretary of State, February 14, 1929, RG 59, File 823.30/76, National Archives.

${ }^{84}$ Of the Great Depression's effects on Leguía's rule, Klarén notes that "Without the continuation of foreign loans and the earnings on customs receipts on exports, the government was on the verge of bankruptcy. This situation, in turn, threatened the solvency of the country's banks, which like their foreign counterparts, had engaged in heavy lending to the government." The flow of loans from the United States, on which Leguía's government had become dependent, slowed to a halt. At the same time, the prices of Peru's principal exports (copper, wool, cotton, and sugar) fell by more than seventy percent while imports dropped precipitously. See Klarén, Peru: Society and Nationhood in the Andes, 267. See also Pike, The Modern History of Peru, 227-29.
} 
fueled impressive rates of economic growth in Peru for most of the 1920s. ${ }^{85}$ Although it was founded on high levels of indebtedness, Leguía's stewardship of the Peruvian economy and emphasis on public works improvements had, in turn, caused many Peruvians to overlook or at least stomach his dictatorial methods. By 1929, however, what had previously been disparate threads of opposition to his rule began to coalesce following his rigged reelection to a third five-year term, a move which historian Daniel Masterson notes "led his opponents to believe his regime would go on indefinitely." 86 When the global economic crisis froze the long-reliable flow of loans into Peru from the United States, the foreign capital-dependent Peruvian economy ground to a halt. There was little left to divert the public's attention from Leguía's repressive rule and his intimate association with the United States. ${ }^{87}$ Twin backlashes against Leguía and his benefactor ensued. American embassy personnel reported growing public unrest and political instability throughout late 1929 and 1930 . Worse for Leguía, there was growing unrest within the Peruvian Army, whose political influence he had long feared. ${ }^{88}$ In July 1930 the extent of the problem became clear to U.S. naval mission chief William S. Pye during a public presentation by the French ambassador to Peru of a motion picture celebrating the French Revolution on Bastille Day. With Leguía in attendance, Pye reported, the Peruvian crowd "stamped and cheered at each scene depicting the success of the revolutionists." The crowd's demonstrated approval "of the ideas of the French revolutionists," Pye noted, was remarkable both for its intensity and for the fact that it

\footnotetext{
${ }^{85}$ Carey, Peru and the United States, 1900-1962, 66-80.

${ }^{86}$ Masterson, Militarism and Politics in Latin America: Peru from Sánchez Cerro to Sendero Luminoso, 33.

${ }^{87}$ James Carey notes that, throughout the 1920s, "The loans floated by New York banking houses provided the Peruvian president with the funds he needed to maintain his hold on the presidency." See Carey, Peru and the United States, 1900-1962, 61.

${ }^{88}$ For example, see U.S. Ambassador to Peru to Secretary of State, November 12, 1929, RG 59, File 823.20/37, National Archives.
} 
took place in the president's presence. Its effect was clear and jarring, he concluded: "the Head of Mission was conscious from that date of a decrease in the feeling of security usually manifested by the President." $\$ 99$

By August of 1930, as policymakers in Washington were just beginning to realize it, members of the U.S. naval mission saw that the writing for Leguía's dictatorship was on the wall. In the new political environment, the naval mission, long seen by Washington as a stabilizing force in Peru, had become a diplomatic liability. It had become too closely associated with a single man. In mid-August Pye reported that the political situation "had become so bad that the Head of Mission decided that a change from the executive to the advisory status was essential," meaning that American personnel should relinquish command of the Peruvian Navy at the earliest possible moment. He made the decision believing that the naval mission's executive control of the Peruvian Navy "was recognized as a Leguía Policy" and could become a lightning rod for public opposition. A substantial weakening of the president's power could subject the mission to political attack "even under the best possible circumstances." 90 On August 20th Pye sent urgent follow-up to both the State Department and Navy Department imploring them to approve a change in the naval mission's status, while U.S. Chargé d'Affaires Ferdinand Mayer cabled Secretary of State Henry Stimson to the same effect. In his note to Stimson, Mayer noted that opposition to the naval mission's continued executive control of Peru's Navy was becoming widespread, and that, in addition to the potential difficulties that could flow from having U.S. officers in control of the Navy in the event of a coup against Leguía (which would no doubt invite

\footnotetext{
${ }^{89}$ Head of Naval Mission to Peru to Director of Naval Intelligence, August 31, 1930, RG 38, Entry E-194, Box 1, National Archives.

${ }^{90}$ Ibid.
} 
attacks on the United States in the Peruvian congress), there was among Peruvian naval officers "a growing feeling that after ten years of administrative control and training received, they should now have administrative control."91 In a later assessment Pye concurred with the Chargé and expressed "sympathy" with the Peruvian officers" position, noting that a belief existed "among the higher ranking officers" that "after ten years training by the Mission, they are capable of self administration.” Moreover, Pye added, senior members of Peru's naval officer corps recognized, as did the Americans, that "a revolution was not far distant" and that Peruvians should be in charge of their own Navy when it came. $^{92}$

The revolution came four days later, led by a politically-minded Army officer, Lieutenant Colonel Luis M. Sánchez Cerro, who led an uprising from his command in the southern city of Arequipa. Within twenty-four hours three of Peru's five military districts had abandoned Leguía and joined the revolution. Public discontent, so widespread since the Peruvian economy had begun its Depression-induced tailspin, gave the revolution critical nourishment. Harold Grow's closeness to Leguía placed him at the center of the emerging turmoil, and complicated Washington's efforts to manage and protect American interests amid the growing chaos. It worked at cross-purposes with the naval mission's efforts to assume an advisory status because, from the time the revolution broke out, Grow dedicated

\footnotetext{
${ }^{91}$ U.S. Ambassador to Peru (Dearing) to Secretary of State, August 20, 1930, filed in RG 38, A1 Entry 48-A, Box 4, National Archives.

${ }^{92}$ Head of Naval Mission to Peru to Director of Naval Intelligence, August 31, 1930, RG 38, Entry E-194, Box 1, National Archives. Earlier in 1930 the U.S. naval mission had begun making overtures in this direction. That year, for example, the Peruvian Navy undertook its annual crucero de verano without U.S. officers in command. The cruise, which owing to better bilateral relations with Chile following the settlement of the Tacna-Arica dispute included a visit to the Chilean port of Valparaiso, proceeded in this manner at Admiral Pye's recommendation, "in order to avoid on the part of the Peruvian officers, any feeling of humiliation in visiting Chile under command of a foreign officer." See Head of Naval Mission to Peru to Director of Naval Intelligence, "Operations for the month of March, 1930," March 31, 1930, RG 38, Entry E-194, Box 1, National Archives.
} 
himself to preserving the dictator's hold on power. It was Grow, for example, who first notified the officers of the naval mission on the afternoon of August 22nd that a revolution seemed afoot in the south of Peru. And it was Grow who huddled with Leguía through the night of August 22nd plotting strategy to quell the uprising. At Leguía's insistence and over Admiral Pye's strenuous objections, Grow then accepted the lead role in a flight operation intended to report to Leguía on conditions in the south and to "drop proclamations over Arequipa denying false charges against the Government which had been used to incite the revolution." Pye voiced his opposition to Grow's participation, stressing that it was dangerously "inconsistent with his status as an officer of the Naval Mission." While dropping leaflets could hardly be considered an act of war, Pye admitted, carrying out the mission would require planes to land and refuel in areas of southern Peru where government control was not assured, meaning they could be subject to capture by elements of Sánchez Cerro's revolutionary movement. But there was little the naval mission chief could do to stop it, and Grow's proximity to power again carried the day. Following direct orders from President Leguía, airplanes flew south on August 23rd. At the dictator's personal insistence, Grow had gone as their leader. ${ }^{93}$ His involvement in the operation, although not technically a violation of the letter of his contract (which merely stated that Grow was "not obliged to take part in any foreign or civil war in which Peru is engaged"), certainly violated the spirit in

\footnotetext{
${ }^{93}$ This view of Grow's actions during the Sánchez-Cerro-led revolution comes from a special report on the episode sent by Admiral Pye to the Director of Naval Intelligence. Although he was clearly frustrated with Grow's conduct, the facts of Pye's assessment are broadly consistent with the account written by Sharon Pope, whose thesis was based heavily on personal interviews and which, not surprisingly, takes a generally more sympathetic view of his activities. See Head of Naval Mission to Peru to Director of Naval Intelligence, "Special Report on activities of Mission, August 22 to 26, 1930," August 31, 1930, RG 38, Entry E-194, Box 1, National Archives. For Pope's treatment of the episode, see Pope, "Harold B. Grow and the Establishment of Aviation in Peru, 1924-1930," 63-73.
} 
which it was written. ${ }^{94}$ A U.S. naval officer had become a partisan in an armed revolt within Peru.

Grow was captured by Sánchez Cerro's forces the morning of August 24th in Camaná, approximately 430 miles south of Lima on the Peruvian coast, following an overnight refueling stop. As the revolution gained momentum and neared Lima that afternoon, Leguía sensed that the end of his rule was near. Within twenty-four hours of Grow's capture, Leguía submitted his resignation to the Peruvian congress and sought refuge on the naval ship Almirante Grau, whose crew he hoped to persuade to take him to Panama. However, Sánchez Cerro, who had quickly consolidated his hold on Peru's military establishment, ordered the ship attacked if it attempted to leave Callao with Leguía aboard. In short order the former president was handed over to the governing Junta for trial and judgment. ${ }^{95}$ Intent on trying Leguía and making examples out of those who had helped prolong his dictatorship, Sánchez Cerro quickly zeroed in on the highly visible Grow, going before the international press corps to call him "a mercenary who has been violating the rules of public right.. ${ }^{96}$ The former aviation chief remained in custody for more than four months in the wake of the revolution, facing charges that he had flown toward Arequipa in an armed aircraft with the intent to bomb revolutionists' positions.

Securing Grow's release from captivity became a significant ongoing concern for the Herbert Hoover administration throughout the latter months of 1930. In defending himself,

\footnotetext{
${ }^{94}$ For excerpt of Grow's contract, see U.S. Ambassador to Peru (Moore) to Secretary of State, February 14, 1929, RG 59, File 823.30/76, National Archives.

${ }^{95}$ Although loyal elements within the Navy at first supported the deposed president and sought to protect him, in short order the Navy came under Sánchez-Cerro's control and Leguía was turned over to the governing Junta for trial and judgment. See "Rebels Halt Leguia in Flight at Port; Martial Law Set Up," New York Times, August 26, 1930, 1.

${ }^{96}$ Sanchez Cerro was so quoted by the Associated Press on August 30, 1930. See "Peru Suspends Constitution Guarantees," Oakland Tribune, August 30, 1930, 1.
} 
the former Director General of Aviation - who for several years had held the naval mission at arm's length while directly serving Leguía - employed a surprising line or argument. Grow wrote to new U.S. Ambassador Fred M. Dearing that "the idea that may have occurred to you that I was independent of the Mission or had separated myself from it is probably due to the more or less independant [sic.] nature of my work in the country. My present contract clearly states that I am a member of the above mentioned Mission." ${ }^{.97}$ He further stated that he had never taken an oath of allegiance to the Peruvian government and that, because he remained attached to the U.S. naval mission, the only person authorized in his contract to interpret his actions and administer discipline was that mission's lead officer. ${ }^{98}$ At the same time, Grow felt the need to explain why he had gone much further than any other naval mission member in supporting Leguía during the revolution. "The second clause of my contract," he argued in a separate letter to Dearing, "is very specific in obliging me to submit myself to 'obey' all orders of the President of the Republic and the Minister of Marine."99

Caught in the middle of an international diplomatic spat, Grow clearly tried to walk back from the modus operandi that had governed his activities as Leguía's Director General of Aviation. His release on January 1, 1931 came only after several months of diplomatic negotiation helped convince a Peruvian court of inquiry that Grow had not flown to Arequipa with hostile intent. ${ }^{100}$ In the end, though, the energy with which he served Leguía made him a polarizing figure in the highly-charged political environment that developed in Peru in 1929 and 1930. His deep involvement in Peru's sovereign affairs had caused considerable

\footnotetext{
${ }^{97}$ Grow's letter to Dearing is quoted in Pope, "Harold B. Grow and the Establishment of Aviation in Peru, 1924$1930, " 70$.

${ }^{98}$ Ibid., 71.

${ }^{99}$ Ibid., 72.

100 "Peru Clears Grow on Bombing Charge: American Air Aide Accused of Siding Against Revolt Wins Acquittal in Special Court," New York Times, 1 January 1931, 23.
} 
difficulty for U.S. foreign policy. And perhaps more clearly than any previous episode, the Grow affair exposed with devastating clarity the problems that could flow from allowing American military personnel to serve as integral parts of another nation's defense establishment.

\section{POST-LEGUÍA TURMOIL IN PERU}

What followed Leguía's overthrow was one of the most turbulent periods in Peru's political history, one that required the United States to retreat from the intimate ties it forged with Peru throughout the Oncenio. The challenge for U.S. policy in the month and years following the dictator's downfall was finding a more cautious approach to relations that acknowledged the disfavor with which a majority of Peruvians, suffering through a devastating economic depression and alienated by years of U.S.-backed dictatorship, had come to view the United States. ${ }^{101}$ Peru's political turmoil during these years was driven in large measure by the economic chaos that continued to wreak havoc in the Peruvian economy throughout 1931 and 1932. The prices of Peru's three most valuable agricultural exports sugar, cotton, and wool - plummeted by 22-percent, 42-percent, and 52-percent, respectively, during the period. The nation's extractive industries (principally copper and oil production), which had eclipsed agriculture to produce the largest share of Peru's exports under Leguía, experienced similarly precipitous price declines in the face of a collapse in international demand. Imports of finished goods, on which the raw material export-oriented Peruvian economy depended, dropped by half as Peruvians' purchasing power fell victim to a depreciating currency, tightening credit markets, and a demand-killing combination of wage

\footnotetext{
${ }^{101}$ For more on this period, see Masterson, The History of Peru, 121-30. See also Clayton, Peru and the United States: The Condor and the Eagle, 142-59.
} 
cuts and growing unemployment. ${ }^{102}$ Anti-U.S. sentiment, which had built up considerably while Leguía was still in power, continued to grow even after he was gone. It reached a breaking point in late 1931 when laborers of the American-owned Cerro de Pasco mining company, protesting layoffs and wage cuts occasioned by falling export prices, clashed violently with police at the company's Mal Paso hydroelectric station. Thirteen miners died in the confrontation, as did three American employees of the company when the demonstrators, outraged at the conduct of the police, proceeded to ransack the station. ${ }^{103}$

U.S. efforts to reframe policy toward Peru were further complicated by the antiLeguía and anti-American political leanings of Peru's new political leadership. While met initially with broad public approbation, the anti-Leguía coup's success could not by itself begin to solve the nation's underlying economic problems or the fiscal crisis they had produced. Serving as the head of the provisional junta that took control following Leguía's ouster, Sánchez Cerro enjoyed several months of relative popularity. His political standing had begun to erode, however, by late 1930 amid seemingly intractable economic difficulties and growing opposition from political foes, chiefly the Alianza Popular Revolucionaria Americana (APRA, a leftist political party founded in opposition to the kind foreign political and economic penetration on which Leguía had built his Oncenio) as well as from individuals within Peru's military establishment who resented Sánchez Cerro's dogged pursuit of the presidency. ${ }^{104}$ Sánchez Cerro's political maneuvering angered a number of his fellow

\footnotetext{
${ }^{102}$ Summary of economic conditions drawn from Klarén, Peru: Society and Nationhood in the Andes, 266-67. Klarén notes that "Workers in Lima were particularly hard hit" by the unemployment crisis, as the jobless rate in Peru's capital city hit 25-percent by November of 1931.

${ }^{103}$ Clayton, Peru and the United States: The Condor and the Eagle, 116-20.

${ }^{104}$ Established in 1924 the young Peruvian political activist Víctor Raúl Haya de la Torre during his exile in Mexico, APRA's five-point founding platform called for 1) action against "Yankee" imperialism; 2) the political unity of Latin America; 3) nationalization of lands and industry; 4) internationalization of the Panama Canal; and 5) solidarity of all oppressed peoples of the world. Although founded as an international movement, it
} 
military officers, who believed the architect of the anti-Leguía coup should resign his position with the junta before making a play to carve out a long-term political future. He refused, however, and scheduled elections for late March of 1931. As Daniel Masterson notes, within weeks of Sánchez Cerro’s February announcement of elections, Peru descended into "open rebellion" and was "on the verge of civil war." Sánchez Cerro sought to defuse the potentially explosive situation in the only way he could, by agreeing to leave the scene through temporary exile in France. It was a short-term political calculation. Although his political enemies tried to prevent it, Sánchez Cerro returned to Peru in early July to contest the election that, in his absence, had been scheduled for October.

Sánchez Cerro's subsequent electoral triumph helped escalate what up to that point had been mainly a political competition into a violent confrontation between APRA, which saw his victory as illegitimate, and conservative political forces aligned with the new president. Fearful that Sánchez Cerro would mobilize the power of the state in a campaign to destroy their movement after his inauguration, APRA members turned to violence to effect change they believed (unjustifiably, according to the Peruvian historian Jorge Basadre) they had been cheated out of at the ballot box. ${ }^{105}$ Violent clashes between APRA activists and the

gained its most credible foothold within Haya's homeland, where it appealed to Peruvians disgusted with Leguía. APRA became a fixture on the Peruvian political scene in 1931, when Haya returned from exile to challenge Sánchez Cerro in that year's presidential election. Beginning during World War II, APRA moderated its platform and assumed a more cooperative view toward the United States. Although Haya de la Torre never won Peru's presidency, his party did remain a prominent player in the nation's politics. In the decades since its founding, APRA has twice seen a member, Alan García, elected president (1985 and 2006). See Masterson, Militarism and Politics in Latin America: Peru from Sánchez Cerro to Sendero Luminoso, 42. See also Carey, Peru and the United States, 1900-1962, 45-50.

${ }^{105}$ Daniel Masterson notes that, although historical opinion is somewhat divided on the honesty of the October, 1931 elections (which Sánchez Cerro won decisively, winning 58\% to Haya de la Torre's 42\%), "the best assessments portray them as the most honest in Peruvian history up to that time." See Masterson, Militarism and Politics in Latin America: Peru from Sánchez Cerro to Sendero Luminoso, 47. Basadre characterizes the 1931 election as one of the fairest in Peru's history, calling Sánchez Cerro's decisive victory (he won 152,062 votes more than Haya de la Torre's 106,007 plus the tallies of two lesser candidates) "un hecho cierto" (a certain fact). See Jorge Basadre, Historia de la República del Perú, 1822-1933, 6. ed., 17 vols., vol. 14 (Lima: Editorial Universitaria, 1968), 167-70. 
armed forces ensued. Vowing to meet violence with force, Sánchez Cerro moved almost immediately to crush APRA once and for all, thus validating the Apristas' fears of the state's hostility. ${ }^{106}$ Within weeks, in late December 1931, the president ordered a police raid on APRA headquarters in the city of Trujillo, in northwestern Peru, that wounded several party leaders. Less than two months later, armed with near-dictatorial powers after the Peruvian Congress had declared martial law, Sánchez Cerro ordered the arrest and exile of all twentythree Aprista lawmakers that had been elected to Congress during the same October elections that had delivered him the presidency. The president intensified his efforts yet again following a failed attempt on his life in early March by a young Aprista gunman inside a church in the Miraflores section of Lima. The assassination attempt not only hardened Sánchez Cerro's resolve to destroy APRA, but heightened his determination to capture its leader, Víctor Raúl Haya de la Torre, who he believed was directly responsible.

Haya's capture by government forces on May 6, 1932 should have marked the crowning success of Sánchez Cerro's anti-Aprista efforts. However, it was followed quickly by events that proved that the conflict with APRA was only growing more intense. The very next day, around 9:00pm on May 7th, enlisted sailors onboard the Peruvian naval cruiser Coronel Bolegnesi in Callao harbor (ten miles from central Lima) overpowered the guards on board their ship, captured and locked up its officers, and ignited a rebellion they hoped would spread throughout the Navy. The mutinous sailors could perhaps have been forgiven if their grievances centered entirely on pay, which had been irregular because of the crisis confronting the national treasury, or living conditions. But the demands they announced

\footnotetext{
${ }^{106}$ Frederick Pike characterizes APRA's post-election commitment to violent redress an embrace of "war without quarter to overthrow the new regime," and notes that, in response, Sánchez Cerro "fought back with furious abandon." The period of violence that ensued, he writes, enveloped Peru "in the throes of the bitterest civil discord in its history." Pike, The Modern History of Peru, 262.
} 
once the rebellion was underway ranged beyond narrowly naval concerns. The sailors, who Robert Scheina notes came from the "lowest grades" $" 107$ of the naval service, presented a proclamation calling for a number of the things that Peruvians suffering through economic depression might have expected (and perhaps even sympathized with) from disgruntled sailors: better treatment of enlisted personnel, greater regulation of the promotion process, better quality food, and limits on the length of naval cruises. Their fifth demand, however, that power be transferred from the military government of Sánchez Cerro to a new civilian administration, had a distinctly political tone and raised red flags within the president's inner circle.

Sánchez Cerro, who was suspicious of the Navy because of its close relations with Leguía, believed the hand of APRA was behind the Callao naval rebellion. His suspicion was later proven to have some foundation in fact. As Peruvian scholar Jorge Ortiz Sotelo notes, during the Bolognesi's 1932 summer cruise stopover at a U.S. naval base in Panama, a number of the ship's junior enlisted personnel had met with exiled APRA representatives, who shared with them the hope that, with the Navy's help, “there would be an uprising [against Sánchez Cerro] across several departments of the government."108 Amid the tense political environment of 1932, though, mere suspicion of APRA involvement was basis enough in Sánchez Cerro's view to take action. He ordered the mutinous crews be attacked if they did not surrender by 5:00am the next morning. An hour before that deadline, the president issued a communiqué calling the rebellion as "part of a revolutionary social plan" that had as its goal not just the overthrow of the Peruvian government, but the sparking of a

\footnotetext{
${ }^{107}$ Scheina, Latin America: A Naval History, 1810-1987, 115.

108 Jorge Ortiz Sotelo, “Las Rebeliones Navales del Callao, 1932 y 1948,” Apuntes 45 (Lima: Universidad del Pacífico, II semestre 1999): 85.
} 
broader revolution of "Communist character" throughout South America. ${ }^{109}$ When the leaders of the rebellion failed to heed the government's demands to surrender, the Navy's loyal elements, which were able to coalesce only because of the efforts of a few key personnel who escaped from the Bolognesi as the mutiny first got underway, opened fire in the early morning hours using three naval aircraft and the deck gun of the submarine R-4 (one of four submarines purchased from the Electric Boat Company during Leguía's reign). Within minutes the mutineers hoisted a white flag above the Bolognesi, whose hull had been pierced by a government volley that set its oil tank ablaze.

Although APRA leaders subsequently disclaimed any operational involvement in the Callao naval mutiny of 1932 , the party did see the rebellious sailors as making common cause. In turn, they took the uprising's failure as an opportunity to launch an even broader offensive against the Sánchez Cerro government. APRA’s commitment to violent, revolutionary action hardened. Its leaders began preparing to stage a major civil-military revolt they hoped would capture the city of Trujillo (APRA's power base) and expand throughout the country. The plan's success depended on the quick defeat of the undermanned Peruvian Army garrison stationed there, which had more arms and ammunition than its skeletal crew could effectively protect. Moving well before their planned steppingoff date, Aprista rebels, many of whom were irate sugar workers, attacked the undermanned garrison on July 7th and captured it in four hours with relative ease. The city of Trujillo fell under APRA control shortly thereafter. However, this rapid success, coming early as it did, could not be duplicated in other regions of the country where APRA activists were not nearly as prepared to move as were their counterparts in Trujillo. As a result, the revolt failed to

\footnotetext{
${ }^{109}$ Scheina, Latin America: A Naval History, 1810-1987, 116.
} 
expand much beyond Trujillo. The Sánchez Cerro government, facing an isolated local revolt rather than the broad-based uprising APRA leaders had anticipated, responded by unleashing a furious military response against the Aprista rebels there. On July 10th and 11th, government forces would pour into Trujillo and crush the revolt.

APRA's de facto leader, Agustín Haya de la Torre (brother of the party's jailed founder), and his inner circle managed to flee the city ahead of government forces' arrival. Those who remained, though, would face the full wrath of Sánchez Cerro's anti-APRA fury. Not content to stand idly by and wait for an onslaught from government forces, the Apristas lashed out, executing the thirty-five Army and Guardia Civil personnel they had been holding since taking the garrison on the 7 th. Five of the bodies were disfigured beyond recognition. These executions enraged Sánchez Cerro, whose government forces unleashed a terrible response after wresting the city from APRA control. Moving house to house through the city, Peruvian troops rounded up all male residents, young and old, whose shoulders and index fingers showed bruises or skin irritations that could be attributed to recent use of a firearm. ${ }^{110}$ Whether one was a bona fide Aprista or not was irrelevant to Sánchez Cerro, who intended to destroy the party once and for all. The suspected rebels were brought to the nearby pre-Colombian ruins of Chan Chan, where more than one thousand were summarily executed. $^{111}$

\footnotetext{
${ }^{110}$ Pike, The Modern History of Peru, 265-66.

${ }^{111}$ Frederick Pike notes that "Aprista spokesmen claimed that close to six thousand men were thus martyred in the environs of Trujillo. A more impartial estimate placed the number of victims at one thousand." Ibid., 266. Daniel Masterson notes that "Responsibility for the massacre has never been accurately fixed, but Sánchez Cerro's troops indulged in massive executions of suspected APRA revolutionaries in the nearby ruins of Chan Chan." Citing Peter F. Klarén's Modernization, Dislocation and Aprismo: Origins of the Peruvian Aprista Party, 1870-1932 (1973), Masterson concludes that the true number of victims was between one thousand and fifteen-hundred. In a more recent work, Klarén concludes that "Thousands of suspected rebels were rounded up and shot amid the pre-Columbian ruins of Chan Chan." See Klarén, Peru: Society and Nationhood in the Andes, 275.
} 
The violent struggle roiling Peru's political establishment reached its apex just as a border crisis with Colombia threatened to engulf Peru in an international war. On August 31, 1932, a band of Peruvian filibusters, angry about Peru's cession of territory to Colombia during the Leguía years, stormed the Amazon River port of Leticia in an attempt to recover it. $^{112}$ The move gave Peru's domestic political crisis a complicated international dimension. Sánchez Cerro, whose anti-Aprista campaign had helped buoy his popularity despite the nation's declining economic fortunes, initially condemned the filibusters' action as the isolated work of a few rogue communists, and pledged to work toward a settlement that would preserve Colombia's claim to the city. He did not count, however, on APRA exploiting the crisis to try and undermine his government. Almost immediately the party began producing propaganda hailing the filibusters as patriotic heroes, and criticizing Sánchez Cerro for failing to back their brave action. The efforts paid off, as public opinion quickly trended in the filibusters' favor and against the president's position. In an attempt to forestall an erosion in his popularity, which he saw as vital to waging an effective fight

\footnotetext{
${ }^{112}$ Much like Peru's southern border with Chile, it's frontier with Colombia had been in dispute since the days of Spanish colonialism. As part of his initiative to settle Peru's borders with its neighbors, Leguía had entered into negotiations with Colombia early in his presidency. At issue was the valuable Amazon port of Leticia, which facilitated shipping across the continent to the Atlantic Ocean. Negotiating in secret with Colombia's Minister to Peru, Fabio Lozano y Torrijos, Leguía concluded an agreement on March 24, 1922 (the Treaty of Frontiers and Free Inland Navigation, also known as the Salomón-Lozano Treaty) which would clarify the two countries' border in the Amazon basin. Under the agreement, Peru granted Colombia frontage on the Amazon River, including Leticia, in return for a large swath of territory south of the Putumayo River (but north of the Amazon) that Colombia had controlled since receiving it from Ecuador in a separate 1916 settlement. Although Peru picked up a substantial portion of territory from the treaty, and gained a strategic advantage over Ecuador (with whom it also had an unsettled border) in the process, Peruvian nationalists were livid that Leguía had handed Leticia over to Colombia, and that he had done so through private negotiations whose full terms were not released. Moreover, nationalists feared that Leguía, who they viewed as slavishly devoted to Washington, had concluded the agreement under pressure from the United States, which they feared was pushing the agreement as a means of finally compensating Colombia for its loss of Panama in 1903. ${ }^{112}$ That the SalomónLozano Treaty was not ratified by the Peruvian Congress until 1928, despite multiple pleas from Washington to do so, stands as evidence of how deeply the nationalists' concerns resonated throughout Peru. Nationalist outrage began to coalesce after the treaty finally received ratification in 1928, and ultimately found expression in the effort by filibusters to seize Leticia by force in August, 1932. On the origins of the Leticia dispute, see St. John, The Foreign Policy of Peru, 165-66.
} 
against APRA, Sánchez Cerro reversed course and publicly threw his support behind the filibusters. In doing so he accepted the risk that his action might lead, as in fact it did, to an outbreak of hostilities with Colombia. Historian Frederick Pike calls Sánchez Cerro's decision reluctant, and argues that it was made not only to preserve the popularity he felt he needed to maintain in order to successfully pursue his overriding objective of destroying APRA, but because to the lowly Lieutenant Colonel, who had experienced a meteoric rise from a mid-level Army command to the Peruvian presidency in little more than a year, public approbation was a "supreme good in itself." 113 As Peter Klarén notes, it was certainly a decision Sánchez Cerro made with the politics of Peru's deteriorating economy in mind. By mid-1932 the former soldier had had little success combating the effects of the depression, and had resorted to heightened deficit spending in an effort to mollify government and military personnel who, he feared, could pose a threat if irregularities in their pay were not resolved. ${ }^{114}$ But the end result was that, whether he did so reluctantly or not, Sánchez Cerro had moved Peru toward war with Colombia in order to enhance his domestic political standing and advance his campaign against APRA. Shortly after coming out publicly in favor of the Leticia filibusters, Sánchez Cerro appointed General Oscar Benavides, Peru’s most widely-respected military figure and a former provisional president of the nation, to command of operations in the Leticia region. In short order, Benavides ordered the conscription of all males between the ages of twenty-one and twenty-five. ${ }^{115}$ With Peru and Colombia were on the verge of war, the position of the U.S. naval mission in Lima grew quite tenuous.

\footnotetext{
${ }^{113}$ Pike goes so far as to call Sánchez Cerro's reversal the indulgence of "an almost childish" need for popular approval. See Pike, The Modern History of Peru, 267.

${ }^{114}$ Klarén, Peru: Society and Nationhood in the Andes, 276.

${ }^{115}$ Masterson, Militarism and Politics in Latin America: Peru from Sánchez Cerro to Sendero Luminoso, 52.
} 


\section{THE END OF THE U.S. NAVAL MISSION}

The more cautious orientation of U.S. policy after Leguía left the naval mission, a product of Washington's closeness with the dictator and a tangible investment in his rule, somewhat in limbo. In the immediate weeks and months following the revolution, the key question confronting the mission was what its continuing functions should be amid the new, highly uncertain political conditions. Very quickly its chief, Pye, decided on the least controversial option. The mission's principal focus, he decided, would be to build on what Peruvians and Americans alike had long recognized as the biggest success of the mission's tenure to date: enhancing Peru's system of naval education. In the new, post-Leguía political environment, in which Peruvian officers exercised executive control of their own Navy (including the Escuela Naval), this meant the creation and development of a Naval War College to prepare mid-level officers for senior leadership positions. Establishment of such an institution had been on the U.S. mission's agenda at least since mid-1929, when Admiral Pye first endorsed the idea as a way of enhancing the professionalism of the Navy's officer corps. It was such a popular idea that even a noted opponent of the naval mission, a retired Rear Admiral and Senator from Peru's northwestern Lambayeque province, called in early 1930 for mission members to devote their efforts to "the creation of a School for Advanced Naval Study." Such an institution, he explained, could educate officers on "the experiences of the last war" and to "explain the evolution which has occurred in strategic and technical principles" as a result. ${ }^{116}$

But efforts to translate those plans into reality gained momentum only after the

\footnotetext{
${ }^{116}$ Speech delivered by Senator (and retired Rear Admiral) Olivera, published by La Prensa, contained as enclosure to Chargé d'Affaires to Secretary of State, January 20, 1930, RG 59, File 823.30/82, National Archives.
} 
mission relinquished executive control and assumed an advisory status. In mid-September, little more than two weeks after Leguía's ouster, Pye wrote to the Director of Naval Intelligence noting that the prevailing attitude in the Peruvian Navy had become "completely demoralized" since the change in government, and that, given the difficult political environment and the "impossibility of extensive operations due to the financial depression," the mission would endeavor "to emphasize naval education, in order to keep the minds of the personnel occupied." ${ }^{\prime 17}$ Naval mission members threw themselves into the task. In October, on Peru's "Navy Day," the mission marked the inauguration of the Escuela Superior de Guerra Naval (Naval War College) with an initial class of six officers, including two naval aviators, and the opening of an abbreviated initial academic year of five months. ${ }^{118}$ In late November, Pye reported that mission members' lectures at the College were progressing "satisfactorily," and that students reported their course of study to be "the most complete discussion of the subject of naval warfare in the Spanish language." As the War College was in its infancy, Pye noted, instructors could do little more than expose students to "the great field of knowledge of naval operations" and "begin the compilation of material for future instruction." 119 Still, by early 1931 the U.S. officers' efforts on the War College made enough of a positive impression on the Sánchez-Cerro government that, instead of seeking its recall to Washington, the president sought renewal of the naval mission's contracts. It was an

\footnotetext{
${ }^{117}$ Head of Naval Mission to Peru to Director of Naval Intelligence, "Request for materials for instruction of Peruvian Navy," September 16, 1930, RG 38, Entry E-194, Box 1, National Archives. Along with the Guardia Civil, the national police force created by Leguía to serve as a political counterweight to the Army, the Navy, in which Leguía took an obvious personal interest, benefited materially from his prolonged rule. As a result, until the success of Sánchez-Cerro's revolution in August 1930 looked assured, the U.S. Embassy reported that the Peruvian Navy represented a politically "reliable" force in support of Leguía. See U.S. Chargé d'Affaires (Mayer) to Secretary of State, August 22, 1930, RG 59, File 823.30/96, National Archives.

${ }^{118}$ Head of Naval Mission to Peru to Director of Naval Intelligence, "Operations for the month of October," November 1, 1930, RG 38, Entry E-194, Box 1, National Archives.

${ }^{119}$ Head of Naval Mission to Peru to Director of Naval Intelligence, "Operations for the month of November, 1930,” November 30, 1930, RG 38, Entry E-194, Box 1, National Archives.
} 
unlikely turn of events, considering how Sánchez Cerro’s had viewed the mission (calling Harold Grow a "mercenary") immediately after toppling Leguía. Although Peru’s financial difficulties would require a reduction in the number of officers assigned to the mission, the Peruvian government expressed a desire to renew two members' contracts for the sole purpose of "conducting" the Naval War College. ${ }^{120}$

Yet even in an advisory capacity the mission's work at the Naval War College posed challenges for U.S. foreign policy, as mission members soon found themselves in the midst of the turmoil over Leticia. As a routine part of his advisory duties at the Naval War College, William O. Spears (Captain, U.S. Navy), who took over as chief of the naval mission in late 1931, regularly delivered lectures (in Spanish) on a variety of topics on everything from international relations to naval strategy and tactics, as his predecessor, Pye, and fellow naval mission members had done. In July 1932, the month before the Peruvian filibusters' move on Leticia, he delivered a series of lectures that featured a scenario closely resembling the developing imbroglio with Colombia. ${ }^{121}$ The purpose of this scenario, as others he and his colleagues developed in their lectures, was to provide students with a set of strategic and operational problems for which they would have to develop and recommend solutions. In this case, Spears presented a situation in which a state of war existed between Peru and Colombia, and in which the Peruvian Navy planned to dispatch a number of gunboats on an expedition from the Peruvian port of Iquitos (on the Amazon River) to Colombian territory

\footnotetext{
${ }^{120}$ Head of Naval Mission to Peru to Director of Naval Intelligence, "Operations for the month of December, 1930,” January 2, 1931, RG 38, Entry E-194, Box 1, National Archives.

${ }^{121}$ Original Spanish-language copies of many of these lectures, although not the one in question, can be found in two bound volumes (both entitled "Conferencias del Curso de la Escuela Superior de Guerra Naval Derecho Internacional, por El Capitan de Navio W.O. Spears") in Box 2, Folders 19 and 20, in the William O. Spears Papers \#3964, Southern Historical Collection, Louis Round Wilson Special Collections Library, University of North Carolina at Chapel Hill.
} 
on the north bank of the Putumayo River. ${ }^{122}$ Because of the geographic orientation of both rivers, which flowed west-to-east within Peru and converged at a point inside Brazilian territory, the expedition would require the Peruvian vessels to travel "several hundred miles" through Brazilian waters before reaching the portion of the Putumayo comprising the Peruvian-Colombian border. Although the Peruvian students' findings and recommendations in response to the scenario are not known, available evidence indicates that, in closing out discussion of the issue, Spears lectured that under the circumstances such an expedition could proceed because existing treaty arrangements between Peru and Brazil permitted it.

Specifically, he noted, a 1909 commercial treaty between the two nations conferred on Peruvian vessels - including, Spears concluded, vessels of war - the right to pass through "such Brazilian rivers as head wholly or partly in Peru." Moreover, he concluded, that right was confirmed by the protocols of the Barcelona Convention and Statute on Freedom of Transit (1921), which guaranteed that Peru could "legally transport land forces and armed vessels across the territory and waters of the Amazon to the Putumayo zone."123 Informed of Spears's July remarks in early September, only after Peruvians' seizure of Leticia, State Department reaction was swift and forceful. Upon receiving the dispatch summarizing the lecture's content, Selden Chapin, a staffer within the State Department's Division of Latin American Affairs, argued to that division's chief, Edwin C. Wilson, that even though the naval mission was laboring in an advisory capacity in Peru, "Spears is still skating over extremely thin ice in lecturing on such subjects as this." "His discussion,"

\footnotetext{
${ }^{122}$ As noted above, by the Salomón-Lozano Treaty concluded by Leguía and ratified by the Peruvian Congress in 1928, Colombia ceded to Peru a sizeable portion of territory that extended Peru's border with Colombia northward to the Putumayo River.

${ }^{123}$ First Secretary of U.S. Embassy (Peru) to Secretary of State, September 12, 1932, RG 59, File 823.30/173, National Archives.
} 
Chapin concluded, "might easily be construed as 'advice' by the ignorant Peruvian military." 124 The concerns Chapin raised in this situation were not unlike those the Department had expressed in late 1923 when naval mission chief Clark Woodward had made his recommendation to dramatically expand the size of the Peruvian Navy's operating fleet: if strategic decisions affecting the stability of Peru's fragile relations with a neighboring country appeared to emanate from the United States, American interests and policy in the region could be jeopardized. The State Department was especially sensitive to implications of U.S. meddling in this case because, since coming into office in 1929, the Herbert Hoover administration had pursued a broad new policy that renounced interventionism in Latin American nations' internal affairs. ${ }^{125}$ Moreover, following Leguía’s August 1930 overthrow, the U.S. naval mission was supposed to be working in a strictly advisory capacity vis-á-vis the Peruvian Navy. Peruvians were supposed to be making the decisions and devising the plans that affected their own national defense. Secretary of State Henry Stimson made that point abundantly clear in a September 30, 1932 directive to the American Embassy in Lima, ordering that "it is essential that members of the [naval] Mission refrain from participating in any way whatsoever in formulation of war plans directed against Colombia." ${ }^{\prime 26}$

Meddling was certainly not how Spears or the U.S. Ambassador to Peru, Fred Dearing, interpreted the officer's activities at the Peruvian Naval War College. In their view, Spears was merely fulfilling his contractual obligations to the Peruvian government. At issue was whether American instruction at the War College should be regarded as a purely

\footnotetext{
${ }^{124}$ Handwritten attachment (undated) to First Secretary of U.S. Embassy (Peru) to Secretary of State, September 12, 1932, RG 59, File 823.30/173, National Archives.

${ }^{125}$ For discussion of Hoover's renunciation of interventionism in Latin America, see Robert H. Ferrell, American Diplomacy in the Great Depression: Hoover-Stimson Foreign Policy, 1929-1933 (New York: W.W. Norton \& Company, Inc., 1970), 215-30.

${ }^{126}$ Secretary of State to U.S. Embassy in Peru, September 30, 1932, RG 59, File 721.23/149, National Archives.
} 
academic exercise, in which scenarios presented to Peruvian students for their use were merely theoretical, or whether it constituted a form of strategic advice and, as such, a direct U.S. contribution to Peru's war planning efforts. ${ }^{127}$ It was a very fine line, and as subsequent correspondence between Dearing and the State Department demonstrates, it was entirely too difficult a line for the United States to walk given the political conditions then prevalent within Peru. In a "strictly confidential" telegram to Secretary Stimson on September 28th (two days before receiving Stimson's directive to refrain from such activity), Dearing made it clear that, in practical terms, he believed that Spears's work did represent a direct contribution to Peru's preparations for war with Colombia. However, he argued, it did not constitute U.S. interference because, by the contracts Spears and his fellow officers had signed, they had to "perforce take part in preparing war plans since their contracts only relieve them from duty in case of a declaration of war." ${ }^{128}$ It was an argument that had merit, and it pointed to a very real problem with maintaining a naval mission with even advisory status in Peru after Leguía's fall. The State Department had gone to great lengths since the first renewal of the naval mission's contracts with Leguía in 1922 to protect U.S. personnel from becoming involved in Peru's armed conflicts, both domestic and international, by insisting that clauses be inserted into each contract expressly forbidding mission members' participation. But in this case, sporadic fighting between Colombian forces and the Peruvian filibusters at Leticia (who enjoyed some support from the Peruvian Army) had not risen to the level of all-out war. Neither Colombia nor Peru had actually made a declaration. And no

\footnotetext{
${ }^{127}$ For example, Spears contended that Peru "certainly has as much right to base their problems for instruction on their most probable enemy, which at present is Colombia, as the U.S. War College at Newport has to consider the Blue-Orange Situations for their studies." See Head of U.S. Naval Mission to Peru to Director of Naval Intelligence, October 18, 1932, RG 38, Entry 48-A, Box 5, National Archives.

${ }^{128}$ U.S. Ambassador to Peru to Secretary of State, September 28, 1932, File 823.30/175, National Archives.
} 
member of the U.S. naval mission occupied an official position that had anything at all to do with devising or implementing war plans. The mission's activities were confined to instruction of mid-level officers at the Naval War College, while the General Staffs of Peru's Navy and Army managed the nation's operating forces and plans for their employment in war. In Dearing's view, such instruction as Spears provided was well within the limits set in his contract with the Peruvian government.

Yet somehow the naval mission was at the center of another diplomatic high-wire act. In the State Department's view, the crux of the problem was that, in the course of his work, Spears had offered his students an interpretation of international law that could easily have had more than theoretical applicability: he may have intended the scenario portraying Peruvian-Colombian hostilities to be purely academic, but there was no way of keeping the Peruvian Navy from interpreting it otherwise. Because of this, despite the advisory and academic nature of Spears's work, it became clear to the State Department that his lecture could have directly influenced matters of war and peace between Peru and Colombia. In the State Department's view it marked the reemergence of the problem that had plagued the U.S. naval mission since the Woodward incident years before - namely, did U.S. officers make recommendations and offer their interpretations in their capacities as Peruvian naval officers, or on behalf of the United States? Were they purely Peruvian assets, or did they act as emissaries of U.S. policy? Under Leguía, when the naval mission exercised executive control over the Peruvian Navy, the lines of authority were clear even if these questions could not always be answered in a manner satisfactory to U.S. foreign policy makers in Washington. But in the unsettled post-Leguía political environment, it became even more difficult to understand, let alone categorize, the impact of the naval mission's activities. 
The message embedded in Secretary Stimson's solution to the problem, conveyed to Ambassador Dearing both on September 30th and again on October 12th (when he instructed that the mission "refrain absolutely from participation in any Peruvian operations preparatory to war" or face recall to the United States ${ }^{129}$ ), was clear. Diplomacy in such delicate situations must be left to the diplomats. Dearing responded appropriately, cabling that "the Naval Mission's duties are now strictly routine and have nothing to do with any South American country." 130 It was a terse follow-up to a more lengthy dispatch in which Dearing, who was close to Spears personally and who saw great value in the work the officer had done at the Peruvian Naval War College, had retreated from his earlier assertion that Spears had made direct contributions to Peruvian war planning. Directly addressing his earlier statement, the Ambassador wrote that, as an advisory body, the naval mission's "primary endeavor is to counsel and train the officers of the Peruvian Navy," work that entailed instructing them "in the methods of preparation of war plans," but which never required U.S. personnel to "take part in making these plans either as a Mission or as individuals." War plans were devised and implemented by the General Staffs of the Peruvian Navy and Army, Dearing further noted, and those staffs "may or may not use material collected by the student officers of the Naval War College in their regular studies of theoretical situations and war games." This was the heart of the problem to Secretary Stimson and the State Department as a whole: given the volatility that had characterized Peru's internal politics since Leguía's overthrow, and given the murky situation between Peru and Colombia over Leticia, the naval

\footnotetext{
${ }^{129}$ Secretary of State to U.S. Ambassador to Peru, October 12, 1932, RG 59, File 721.23/242, National Archives.

${ }^{130}$ U.S. Ambassador to Peru to Secretary of State, October 13, 1932, RG 59, File 721.23/274, National Archives.
} 
mission's work at the War College left far too much of U.S. policy to chance. ${ }^{131}$

Dearing disagreed but carried out the Secretary's instructions. In accordance with Stimson's directives, the Ambassador reported that the U.S. naval mission was "abstaining from taking part in the studies relating to the Colombian situation," while Spears had taken care to remove himself from "even passive participation" in the study of possible Peruvian naval action against Colombia. ${ }^{132}$ However, as the Ambassador noted in a separate dispatch a few days later, this did not change the fact that, in his view, "a naval mission must, as all military missions must, concern itself with theoretical war problems." It was quite natural, he wrote, that in countries such as Peru where "there is no experience or developed ability in making of plans," American missions should be willing to provide such instruction "within the proper limits," as, in his view, Spears had done in Peru. "In peace there would be no criticism of such activity," he concluded. Dearing's fear was that the difficult circumstances surrounding the naval mission's work at Peru's Naval War College might scare the United States away from providing such valuable services to Latin American nations in the future. ${ }^{133}$ A retreat from this sort of engagement, his October 6th dispatch to Stimson concluded, would be unfortunate, despite the periodic diplomatic complications the U.S. naval mission's activities in Peru had caused. Throughout the mission's tenure but especially since assuming its advisory role in August of 1930, its officers had done much to facilitate closer embassy contacts with Peruvian government officials. Moreover, Dearing stressed, the mission had directly supported U.S. commercial interests in the country. But perhaps most importantly, it had helped sustain the "pro-American" orientation of Peru's Navy and aviation services "at a

${ }^{131}$ U.S. Ambassador to Peru to Secretary of State, October 6, 1932, RG 59, File 721.23/273, National Archives. 132 Ibid.

${ }^{133}$ U.S. Ambassador to Peru to Secretary of State, October 14, 1932, RG 59, File 721.23/306, National Archives. 
time when the country is full of attacks on the United States." 134

\section{CONCLUSION}

With little left to do, the U.S. naval mission's days in Peru were numbered. In his October 1932 monthly summary of the mission's activities, Spears pinpointed the problem the mission then confronted. To comply with Washington's new orders “to do nothing unneutral" while also meeting its contractual obligation to the Peruvian government "to do everything possible to increase their [the Peruvian Navy's] efficiency," he wrote, was an impossibility. Ever since making the transition from executive control to advisory status, the naval mission had been devoted entirely to Peru's Naval War College, and absent carrying out meaningful instruction there, he reported, there was little of substance that U.S. personnel could provide to the Peruvian Navy. Under the circumstances, he concluded, it appeared that the "first aim of the Mission now is to keep the Mission going as long as possible hoping that the present situation [with Colombia] will be amicably adjusted" - the implication being that, with peace between Peru and Colombia restored, new officers might be sent and the naval mission could resume normal advisory duties. ${ }^{135}$ As it turned out, however, time was not on the naval mission's side. By late 1932 and early 1933, several developments - the worsening fiscal crisis confronting the Peruvian government, seemingly chronic political instability, the intensification of Peruvian-Colombian hostilities over Leticia, and a rising tide of antiAmericanism fed by Peruvians' lingering anger over U.S. support for Leguía and the deepening economic depression - ensured that the naval mission members' current contracts

\footnotetext{
${ }^{134}$ U.S. Ambassador to Peru to Secretary of State, October 6, 1932, RG 59, File 721.23/273, National Archives.

${ }^{135}$ Head of U.S. Naval Mission to Peru to Director of Naval Intelligence, "Naval Mission Activity," October 18, 1932, RG 38, Entry 48-A, Box 5, National Archives.
} 
would be their last. In January of 1933 Sánchez-Cerro declined to extend the mission's contracts further, and in early March its members departed Callao on a Grace Line vessel bound for New York. ${ }^{136}$ The naval mission's nearly thirteen-year tenure in Peru was over. Even so, the U.S. Navy would remain a key player in the conduct of U.S. diplomacy toward Peru.

${ }^{136}$ Chief of Naval Operations to All Bureaus and Offices, "U.S. Naval Mission to Peru; discontinuing of," March 28, 1933, RG 38, Entry 48-A, Box 4, National Archives. 


\section{CHAPTER 4: A NEW NAVAL DIPLOMACY, 1928-37}

As the Great Depression deepened and Peruvians expressed growing anger with the United States, American policy toward that nation entered a period of adjustment. For eleven years, from 1919 to 1930, Washington had maintained intimate ties with Peru, offering close, continuing support to a Leguía dictatorship that, although it fostered remarkable economic growth, repressed the will of its people and alienated a substantial share of the Peruvian population. From the time of President Augusto Leguía’s ouster in August of 1930 through 1932, U.S. foreign policy makers witnessed the after effects of that support as political turmoil, violence, and anti-American sentiment within Peru accelerated while economic conditions steadily deteriorated. Similar dynamics played out simultaneously across much of Latin America, as governments in a majority of Latin American countries experienced coups or revolutions between 1930 and 1933. ${ }^{1}$ Increasingly sensitive to criticisms of American imperialism that were emanating from the nations to its south, Washington began working to fashion a more cautious, hands-off policy appropriate to the increasingly delicate situation. ${ }^{2}$ President Herbert Hoover turned U.S. foreign policy toward Latin America away from armed interventionism and his successor, Franklin D. Roosevelt, embraced the policy and gave it its

\footnotetext{
${ }^{1}$ David Schmitz notes that "By 1933, dictators ruled fifteen of the twenty Latin American republics, most of them having come to power in the previous two years and enjoying the support of the United States." David F. Schmitz, Henry L. Stimson: The First Wise Man, Biographies in American Foreign Policy (Wilmington: Scholarly Resources, Inc., 2001), 92.

${ }^{2}$ In 1928, at the Sixth International Conference of American States in Havana, Cuba, Latin American resentment over U.S. interventionism boiled over. As Lester Langley notes, when discussion turned to the issue of Nicaragua, where the United States had maintained military forces since 1912, "anti-American diatribes" rang throughout the meeting hall. See Langley, America and the Americas: The United States in the Western Hemisphere, 131-32. Also driving the United States toward a policy of non-intervention was the Great Depression, which, especially under Hoover, led the U.S. government to curtail spending on activities abroad, including the Navy.
} 
enduring moniker, the Good Neighbor Policy. ${ }^{3}$ Both realized that for the policy to ultimately be successful, the United States would have to make attempts to alter negative popular attitudes of Latin Americans toward the United States. As this chapter will discuss, both also saw the U.S. Navy playing a central role in that effort. Accordingly, throughout Latin America, under the banner of good neighborism U.S. naval vessels and personnel engaged in public diplomacy aimed, among other things, at demonstrating neighborly respect for the sovereignty of Latin American nations. This meant that, just as it had during Leguía's Oncenio, the U.S. Navy would play an integral part in shaping U.S. policy toward Peru.

\section{WASHINGTON'S SEARCH FOR A POLICY}

The escalation of political violence within Peru and the unfolding crisis over Leticia made settling on a new policy an urgent matter for U.S. foreign policymakers in Washington. The United States had already perceived a need to craft a new framework for relations with Peru at the time of Leguía's fall, but throughout the nearly two years between his overthrow and mid-1932, American policy was characterized by drift. The fundamental problem, U.S. Ambassador Fred Dearing wrote in September of 1931, was that throughout Leguía's eleven years in power Washington had cast its diplomacy toward Peru in far too personal terms, carrying out relations more with Leguía personally than with the nation as a whole. The dictator's friendship and affection for the United States had been "so intense and profuse," he wrote, "that it amounted to favoritism" and constituted an "addiction" that the majority of Peruvians came to resent. Washington had erred in catering to the dictator's "unlimited

\footnotetext{
${ }^{3}$ Throughout this work, when referring to the formal, non-interventionist policy pursued by the Hoover and Roosevelt Administrations, I will use the phrase "Good Neighbor Policy," complete with capitalization. Often, however, when referring to oft-stated non-interventionist sentiments I will employ the phrases "good neighbor," "good neighborly," or "good neighborism."
} 
appetite for flattery," he continued, and had unwisely heaped "fulsome praise" on him "with no sense apparently of how ridiculous...and how inevitably the unwarranted praise and fulsomeness would bedevil our future relations." As a result, he wrote, in the post-Leguía era Peruvian public opinion was characterized by "suspicion and dislike" of the United States - a situation made worse by the fact that "it had to be suppressed during Leguía's time" and because Peruvians believed that the United States had aided the dictator in doing so. Speaking to the enormity of the challenge confronting Washington, Dearing noted that although it was animated by an "intense nationalism," by anti-Americanism, and by a revulsion to all things Leguísta, the Sánchez Cerro government came "nearer to expressing the real feelings of the Peruvian people" than any government in recent Peruvian history. ${ }^{4}$

The problem facing the United States, then, was how to undo the damage wrought by more than a decade of invited meddling in Peru's internal affairs while still protecting the economic and strategic interests that had caused cozy relations with Leguía to make sense in the first place. The delicate situation in Peru was part and parcel of the broader challenge the United States faced in recasting its foreign policy approach to Latin America in the late 1920s and early 1930s. By the time Franklin D. Roosevelt assumed the U.S. presidency in early 1933, the costs (both financial and political) of U.S. intervention in Latin America had become unacceptably high. Even though American foreign policymakers like Henry L. Stimson, Hoover's Secretary of State, believed interventions had been well-intentioned and

\footnotetext{
${ }^{4}$ Dearing's thoughts are communicated in a lengthy, wide-ranging assessment of U.S.-Peruvian relations made in response to a request made by Assistant Secretary of Francis White of all U.S. diplomatic representatives in Latin American countries for detailed reports on "the international relations of the state to which he is accredited and on certain other matters of fundamental importance to the establishment of more cordial relations between this Government and its neighbors" in advance of the Seventh International Conference of American States, which was to be held in Montevideo, Uruguay, "at the end of 1932 or in early 1933." The conference was not held until late 1933. For White's instructions, see Assistant Secretary of State to American Diplomatic Officers in Latin American Countries, October 10, 1930, RG 59, File 710.G/4A, National Archives. For Dearing's detailed response, see U.S. Ambassador to Peru to Secretary of State, September 2, 1931, RG 59, File 710.G/44, National Archives.
} 
in the "best interests" of the countries where they took place, the repeated use of force to protect U.S. interests in Central America and the Caribbean had "instead of promoting feelings of friendship...initiated feelings of hate and hostility" throughout Latin America towards the United States. ${ }^{5}$ As Stimson noted, the challenge facing the United States in Latin America was developing policies so that "less and less pressure would be necessary on the part of the United States to keep matters straight."6

Amid the intense unrest of early 1933 in Peru, when Sánchez Cerro was trying to mobilize the nation for war with Colombia even as its economy slumped to new depths, Ambassador Dearing proposed a policy he believed would do just that. A veteran diplomat, Dearing saw problems with the longstanding U.S. policy of dispatching warships to Latin American countries in times of crisis. He wrote to Secretary Stimson that, fundamentally, because United States had long adhered to a broad policy of armed interventionism in Latin America, when U.S. naval vessels arrived in Latin ports for any purpose, they were more often than not "interpreted as having ulterior purposes and being in a sense admonitory." Moreover, he continued, U.S. interventionism had stoked broad resentment in South America despite the fact that, in practice, all interventions carried out under the "Roosevelt Corollary" had been confined to the Caribbean and Central America. The solution, Dearing argued, was not to reduce the U.S. Navy's visibility in Latin America, but to increase it. The United States should begin sending its naval vessels into ports throughout Latin America on a regular basis, he urged, in order to help the peoples of those countries "become accustomed to the sight of our war vessels engaged in friendly missions." The idea behind Dearing's proposal was that if American naval visits were regular occurrences, individual visits would

\footnotetext{
${ }^{5}$ Stimson quoted in Schmitz, Henry L. Stimson: The First Wise Man, 91.

${ }^{6}$ Ibid., 92.
} 
not "stir up resentment and excitement" as had become the norm. Higher visibility would have a calming effect in countries such as Peru that were suffering through serious bouts of depression-induced economic and political instability, would give confidence to U.S. citizens conducting business there, and would, in general, render American interests throughout Latin America more secure. It was "only common sense to take preventive measures and to take them in time," he concluded. Doing so would ensure the creation of an atmosphere throughout the hemisphere that more effectively promoted U.S. interests and enhanced American "prestige."7

Coming as it did at a peak moment in Peru's political and international crises, and during a month when the U.S. economy sunk to alarming new lows, Dearing's recommendation landed in the State Department with a thud. ${ }^{8}$ The Assistant Chief of the Department's Division of Latin American Affairs, H. Freeman Matthews, strongly disagreed with the Ambassador's prescription, writing in response that visits by U.S. warships to Latin American ports were "usually misunderstood and cause[d] friction" - a conclusion with which the Department's most senior Latin America hand, Edwin C. Wilson, and Assistant

\footnotetext{
${ }^{7}$ U.S. Ambassador to Peru to Secretary of State, February 22, 1933, RG 59, File 721.23/1358, National Archives.

${ }^{8}$ February of 1933 saw the near-collapse of the U.S. banking system as the erosion of public confidence in banks accelerated in response to a U.S. Congressional investigation into that sector's role in the 1929 collapse of the U.S. stock market. As American banking teetered on the brink of collapse, President-Elect Franklin D. Roosevelt and President Herbert Hoover carried out a most uncooperative transition that was to culminate in Roosevelt's inauguration on March 4, 1933. See Dallek, Franklin D. Roosevelt and American Foreign Policy, 1932-1945: With a New Afterword, 23-28. For more on the economic crisis within the United States during these months, see Fiona Venn, The New Deal, BAAS paperbacks (Edinburgh: Edinburgh University Press, 1998), 26-45. For excellent overviews of the Hoover-Roosevelt transition and the scale of the economic devastation that ravaged the United States during the winter of 1932-33, see William Edward Leuchtenburg, Franklin D. Roosevelt and the New Deal, 1932-1940, [1st ed., The New American Nation Series (New York: Harper \& Row, 1963). For a more recent treatment, see Roger Biles, A New Deal for the American People (DeKalb: Northern Illinois University Press, 1991).
} 
Secretary of State Francis White both concurred. ${ }^{9}$ But their shared opposition to naval cruises for goodwill purposes would prove to be short-lived. Relative calm would fall over Peru's domestic and international crises by mid-1933, following the ascent of General Oscar Benavides to the presidency after Sánchez Cerro's assassination by a lone Aprista gunman. Benavides quickly negotiated a settlement of the Leticia problem with Colombia and, at home, retreated from Sánchez Cerro's hard line position on APRA by lifting martial law and allowing the party to resume limited political operations. ${ }^{10}$

While calmer conditions began to prevail in Peru, the State Department started warming up to the idea of using U.S. naval vessels for goodwill diplomacy throughout Latin America. That is because in his first months in office the new President of the United States, Franklin D. Roosevelt, had proclaimed a "Good Neighbor Policy" renouncing armed intervention in Latin America and committing the United States to the shaping of "an atmosphere of close understanding and cooperation" in the Americas. ${ }^{11}$ It was not a policy

\footnotetext{
${ }^{9}$ Wilson wrote that he "entirely agree[d]" with Matthews's assessment, and added that, "as a general rule, they [U.S. naval vessels] should not make any [visits] to L.A." Matthews's and Wilson's comments are handwritten in the margins of Dearing's dispatch, and Assistant Secretary White's approval of their views is given with his initials, dated March 10, 1933. See U.S. Ambassador to Peru to Secretary of State, February 22, 1933, RG 59, File 721.23/1358, National Archives.

${ }^{10}$ Masterson, Militarism and Politics in Latin America: Peru from Sánchez Cerro to Sendero Luminoso, 53-59.

${ }^{11}$ In his inaugural address, Roosevelt declared that "In the field of world policy I would dedicate this Nation to the policy of the good neighbor - the neighbor who resolutely respects himself and, because he does so, respects the rights of others - the neighbor who respects his obligations and respects the sanctity of his agreements in and with a world of neighbors." Although a general declaration, the "Good Neighbor Policy" soon became associated most closely with Latin America. The next month, in addressing the Governing Board of the PanAmerican Union on the occasion of "Pan-American Day," Roosevelt declared that "The essential qualities of a true Pan Americanism must be the same as those which constitute a good neighbor, namely, mutual understanding, and, through such understanding, a sympathetic appreciation of the other's point of view. It is only in this manner that we can hope to build up a system of which confidence, friendship and good-will are the cornerstones." See Roosevelt and Rosenman, The Public Papers and Addresses of Franklin D. Roosevelt, 2, 14, 130. Although the policy gained its "Good Neighbor" brand name under Roosevelt, the turn in U.S. policy toward non-intervention began in earnest under President Herbert Hoover. See DeConde, Herbert Hoover's Latin-American Policy, 125. See also Ferrell, American Diplomacy in the Great Depression: Hoover-Stimson Foreign Policy, 1929-1933, 215-30.
} 
born, as some scholars have suggested, entirely of U.S. altruism. ${ }^{12}$ Although backing away from the tactic of armed intervention, U.S. foreign policymakers were intent on maintaining the decisive sway the United States had spent more than a century painstakingly developing throughout Latin America. ${ }^{13}$ Washington's embrace of non-intervention under the banner of good neighborism was calculated to maintain that hard-won influence, but to do so in a less obtrusive way. ${ }^{14}$ It was a clear departure from decades of heavy-handed intervention, and the United States would have to back it with substantial action. As Washington began searching for tangible ways to demonstrate its good neighbor bonafides to Latin America, public exhibitions of goodwill assumed great importance. To Roosevelt, who had served as Assistant Secretary of the Navy under President Woodrow Wilson and who had maintained a lifelong love affair with the sea, the Navy was the perfect instrument to assume such an important role. $^{15}$

\section{GOODWILL NAVAL DIPLOMACY BEFORE THE GOOD NEIGHBOR}

\footnotetext{
${ }^{12}$ Shaped by inter-American cooperation during World War II, early scholarly interpretations of the Good Neighbor Policy tended to explain the U.S. embrace of non-intervention as an expression of U.S. altruism and genuine respect for the sovereignty of Latin American nations. Samuel Flagg Bemis, for example, argued that it was rooted in a "respect for the New World and a sincere desire to get along with it on the most cordial and friendly terms possible, as a means of cultivating commerce and culture, and above all of promoting peace." See Bemis, The Latin American Policy of the United States, 256.

${ }^{13}$ On U.S. preponderant influence in Latin America since independence, see John J. Johnson, A Hemisphere Apart: The Foundations of United States Policy Toward Latin America, The Johns Hopkins Symposia in Comparative History (Baltimore: Johns Hopkins University Press, 1990); Schoultz, Beneath the United States: A History of U.S. Policy Toward Latin America. For a good overview of U.S. efforts to expand its influence after World War I, see Tulchin, The Aftermath of War: World War I and U.S. Policy Toward Latin America.

${ }^{14}$ Later interpretations of the Good Neighbor Policy, framed in part by the Cold War, took a more skeptical, balanced view of American motivations. For example, see Donald Dozer, Are We Good Neighbors? (Gainesville: University of Florida Press, 1959). Although little scholarly work has been done on the Good Neighbor Policy in recent decades, the best works address both its international and cultural dimensions. For example, see Bushnell, Eduardo Santos and the Good Neighbor, 1938-1942; Pike, FDR's Good Neighbor Policy: Sixty Years of Generally Gentle Chaos; Roorda, The Dictator Next Door: The Good Neighbor Policy and the Trujillo Regime in the Dominican Republic, 1930-1945.

${ }^{15}$ For more on Roosevelt's affinity for all things naval and seagoing, see Robert F. Cross, Sailor in the White House: The Seafaring Life of FDR (Annapolis: Naval Institute Press, 2003).
} 
In order to understand the systematic implementation of goodwill naval cruising in Latin America under the Good Neighbor Policy, it is necessary to briefly examine the bureaucratic tug-of-war between the Navy and State Departments going back to the First World War. Beginning with American involvement in that war, Navy and State Department officials alike began to recognize that naval power was becoming more integral to the conduct of U.S. policy toward Latin America. Underlying that conviction was a shared sense that naval activity outside of combat operations was inherently diplomatic activity. A useful tool for understanding the emergence of this consensus is the work of naval theorist Ken Booth, who defines "naval diplomacy" as the use of naval power to "affect the thinking and behaviour of other governments with little or no intention or expectation of using brute force." ${ }^{" 16}$ Booth's definition proceeds from the understanding that the versatility, mobility, range, and symbolic power of naval vessels make them more useful instruments of a nation's diplomacy than other varieties of military power (such as ground armies or air forces). That is because, as he argues, wherever a nation's navy ventures in the world, its vessels are "small mobile pieces of national sovereignty" and carry with them the full weight of a nation's intentions and commitments. ${ }^{17}$ This applies, he suggests, whether naval assets are engaged in a more coercive style of naval diplomacy, of the sort that often occupied the U.S. Navy in the Caribbean during the early 20th century, or whether they are carrying out actions aimed at fostering goodwill and enhancing the sponsor nation's international "prestige" actions of the type that became important as the United States abandoned interventionism in Latin America and began pursuing the good neighbor approach.

\footnotetext{
${ }^{16}$ Booth, Navies and Foreign Policy, 41-45.

${ }^{17}$ Ibid., 33-36.
} 
The U.S. Navy had embraced a central role in carrying out the nation's Latin America policy during the First World War, when it detached four armored cruisers from its Pacific Fleet for diplomatic duty in South America. Under the command of William Banks Caperton (Rear Admiral, U.S. Navy), the ships' objective was to cultivate friendly, pro-Allied sentiments among South America's leading powers. It was a mission that Caperton, who had spent several years leading "gunboat diplomacy" interventions in the Caribbean before the war, pursued with great enthusiasm. From mid-1917 through the end of the war in late 1918, his squadron staged highly publicized goodwill visits to South American ports including Rio de Janeiro, Montevideo, Buenos Aires, and Valparaiso. Sensing the need to connect with populations as well as leaders in those countries, in each port he orchestrated and financed activities designed to maximize locals' contact with U.S. vessels and personnel, including concerts, parades, balls, and a variety of social gatherings. It was a "wonderful chance," to serve the American war effort, Caperton told his men - "a little different perhaps than we would do in battle, but nevertheless a means to an end."18 His effectiveness as a wartime sailor-diplomat impressed the State Department. In every country he visited, American diplomatic representatives sent glowing reports of his efforts back to Washington, the consensus being, as David Healy notes, that "no man...could have done better as a propagandist and advocate" of American interests. ${ }^{19}$

Encouraged by his successes and by the favor with which U.S. diplomats had greeted his efforts, the following year, just before retiring from naval service, Caperton urged the Navy Department to maintain an active role in the forefront of the nation's diplomacy.

\footnotetext{
${ }^{18}$ David Healy, "Admiral William B. Caperton: Proconsul and Diplomat," in Behind the Throne: Servants of Power to Imperial Presidents, 1898-1968, ed. Thomas J. McCormick and Walter LaFeber (Madison: University of Wisconsin Press, 1993), 92.

${ }^{19}$ Ibid., 91.
} 
While the Navy's primary mission was always to prepare for war, he wrote to Chief of Naval Operations William S. Benson, its important secondary mission was to maintain a presence in "all the important seacoast countries of the world" as a "visible and active manifestation of the friendships, and when necessary, the power of the United States." Such a presence was, "in the best sense of the word, national advertising," he argued, that served to heighten U.S. prestige and yield great benefits "out of proportion with the cost" such operations entailed. Such an investment was, in his view, especially necessary in Latin America, where a permanent, friendly naval presence would "render enormous aid" not only to U.S. efforts to forge productive inter-American cooperation, but to nascent U.S. efforts to expand trade and roll back European commercial and strategic influence in South America. ${ }^{20}$ Coming as it did at a moment when State Department leaders were eager to expand U.S. strategic and commercial influence beyond the Caribbean to all of South America, Caperton's recommendation met with "unhesitating" agreement when it arrived at Foggy Bottom. Policymakers in the U.S. Navy, on the other hand, swiftly rejected it. Officers of the Navy's Planning Committee did not want to detach any significant amount of the service's overall force for permanent diplomatic duty. Instead, they decided, it was better to maintain the bulk of the service's capable fighting vessels in a single battle fleet whose sole focus was preparing for war. $^{21}$

\footnotetext{
${ }^{20}$ Rear Admiral W.B. Caperton to Chief of Naval Operations, May 12, 1919, RG 45, Subject File UP, Box 679, National Archives.

${ }^{21}$ Of Caperton's recommendation that the Navy maintain vessels on permanent foreign stations, acting Secretary of State Frank L. Polk wrote that "The Department of State unhesitatingly concurs in the recommendations made by Rear Admiral Caperton in his report and sincerely hopes that the Navy Department may see its way to putting his recommendations into effect." See Acting Secretary of State to Secretary of the Navy, June 21, 1919, RG 59, File 811.30, National Archives. For the Navy Planning Committee's response to Caperton's recommendation, see Healy, "Admiral William B. Caperton: Proconsul and Diplomat," 93-94.
} 
Although wary of making a broad, global commitment to diplomatic duty of the sort envisaged by Caperton, Navy leaders did come to recognize the special demands placed on their institution by the nation's policy toward Latin America. For years the Navy had made a practice of responding individually to U.S. diplomats' frequent calls for vessels to assist in crises in Caribbean and Central American countries. By 1920 those calls had become so numerous that they made the old case-by-case method of coordination unworkable. As one officer in the Office of Naval Operations characterized it, the State Department's seemingly constant demands for naval assets in the Caribbean rose to the level of "abuse" with diplomats and consular agents seeming to demand ships "simply on the basis of alarmist rumors." ${ }^{22}$ Accordingly, in May of 1920 the Navy relented and agreed to establish a small squadron with the diplomatic role of patrolling and keeping order within the American empire in the Caribbean. ${ }^{23}$ The unit was designated the Special Service Squadron to reflect both its unique role outside the Navy's preferred line of business (preparing for war), as well as the close association it would have with the State Department. As Charles Freeman (Captain, U.S. Navy), a staff officer intimately involved in its establishment, later noted, the Squadron's creation was something of a defensive bureaucratic move by Navy leaders: they

\footnotetext{
${ }^{22}$ Comments by Captain Charles S. Freeman, who would eventually command the Special Service Squadron in the 1930s, are contained in Yerxa, Admirals and Empire: The United States Navy and the Caribbean, 1898$1945,81$.

${ }^{23}$ Donald Yerxa argues that the Special Service Squadron was established to protect the American maritime empire in the Caribbean. He writes, "Throughout history maritime empires have based their policies and strategies on commerce, overseas dependencies, and naval forces. Because their vital interests are bound up in overseas trade, maritime empires utilize their navies not simply to defend themselves from other powers, but also to police important sea-lanes and to assist in pacification operations. Political instability within the imperial sphere of influence is anathema to a major maritime power. Consequently, the maritime empire exhibits two recurrent and complementary concerns: (1) the need to protect the imperial sphere of influence from external threats posed by other major powers, and (2) the need to police the imperial sphere of influence to remove internal threats to the stability of the empire." When the Special Service Squadron was established in 1920, there was little likelihood of an external threat to America's Caribbean empire emanating from Europe or elsewhere. The principal concern of the United States in creating the Squadron, then, was maintaining a stability there favorable to U.S. interests. See ibid., 1.
} 
hoped that having a dedicated unit in the Caribbean would give the Navy an independent means of "evaluating the relative necessities in disturbed areas" while 1) eliminating the need to detach vessels from other units for tours of unspecified duration and, 2) limiting the total number of ships engaged in diplomatic activity. ${ }^{24}$ Nevertheless, it was a unit established for the sole purpose of helping to carry out U.S. foreign policy. Its creation signaled that, however haltingly, the Navy was moving away from the kind of outright opposition its leaders had expressed to Admiral Caperton's proposal for permanent diplomatic naval stations abroad.

The Special Service Squadron's official charge at its creation was to "promote friendly relations and contribute to the growth of a better understanding between the United States and the other republics of the Western Hemisphere." ${ }^{25}$ Not surprisingly given the conditions that spawned it, however, the Squadron was most often called upon in subsequent years not to show the flag or foster goodwill, but to protect American citizens and interests in the Caribbean region. Indeed, this gunboat diplomacy mission eclipsed that of goodwill cruising for most of the Squadron's existence, even though its commanders at different times sought to emphasize the goodwill diplomatic function. According to historian Donald Yerxa, from its creation in 1920 until 1934, vessels of the Squadron responded to State Department calls for crisis assistance some fifty-one different times. On several occasions, such in Nicaragua between 1926 and 1933, and in Cuba from 1933 to 1935, the assistance it

\footnotetext{
${ }^{24}$ Ibid., 81-82. Also, historian Richard Millett generally agrees, noting that, to the Navy, the Squadron's creation carried with it the hope of an "additional, unstated benefit" - that it would bring about a "lessening of the friction caused by the practice of maintaining vessels in area ports for long periods when political disturbances were feared. By allowing American diplomats to communicate directly with a squadron based on the Canal Zone ships could be dispatched to potential trouble spots with considerably greater rapidity, thereby obviating the necessity of keeping a vessel hovering off any area of potential disturbances." Millett, "The State Department's Navy: A History of the Special Service Squadron, 1920-1940," 119.

${ }^{25}$ Yerxa, Admirals and Empire: The United States Navy and the Caribbean, 1898-1945, 83.
} 
provided was both large-scale and long-term in nature. When commanders of the Special Service Squadron found time to engage in goodwill cruising in the Caribbean, they often met with stiff resistance from diplomats who did not want the Squadron straying from what they viewed as its interventionist raison d'être. In their view the Squadron should remain firmly under State Department supervision because the Caribbean was too delicate a region to permit naval officers to freelance as diplomats. While the State Department saw merit in conducting goodwill naval diplomacy further south, in South American waters, and had supported Admiral Caperton's proposal for a permanent goodwill naval presence there, in the Caribbean U.S. foreign policymakers wanted naval power was to play a narrower, more remedial role. ${ }^{26}$ Indeed it seemed throughout most of the 1920 s that, although they agreed that naval power had an important role to play in carrying out U.S. policy in Latin America, Navy and State Department leaders could not see eye to eye on the specific roles naval assets should play and where.

\section{HERBERT HOOVER'S GOODWILL TOUR}

The gulf between U.S. foreign policymakers and naval leaders on the utility of goodwill cruising narrowed considerably after President-Elect Herbert Hoover made a sevenweek swing through Central and South America in late 1928, and it began to disappear altogether when, after assuming power, he moved the United States away from its longstanding policy of armed interventionism in Latin American nations. Sailing aboard several U.S. Navy vessels, Hoover's seven-week visit - deemed his "goodwill tour" - was a catalyst for this major shift in American foreign policy. It represented a meeting of the

\footnotetext{
${ }^{26}$ Ibid., 86-87.
} 
minds between Hoover and Leo S. Rowe, Director General of the Pan American Union, who, confident of Hoover's victory, had proposed it to the then-Republican nominee more than a week before the 1928 presidential election. ${ }^{27}$ Latin America was the only region of the world that the well-traveled president-elect had never visited, and before leaving, he remarked that the trip represented an opportunity to pay "friendly calls upon our neighbors to the south" and get acquainted with them. ${ }^{28}$ Six of the ten nations Hoover visited on his tour were on the South American continent, marking the first time a U.S. president (although he had yet to take office) had set foot on that continent; in total, the trip marked only the third time a U.S. president had visited a Latin American country. ${ }^{29}$ In that sense it was a grand gesture, one that American foreign policymakers hoped in and of itself would demonstrate the credibility of U.S. desires for more positive, productive inter-American relations. ${ }^{30}$ For his part, Hoover saw the trip as a first step in the broad reorientation he hoped to effect in U.S. policy toward Latin America. ${ }^{31}$

\footnotetext{
${ }^{27}$ Alexander DeConde notes that, as a highly successful mining engineer and businessman, Hoover had visited every continent of the world except South America by the time of his election to the presidency. DeConde, Herbert Hoover's Latin-American Policy, 13-15. See also Leuchtenburg, Herbert Hoover, 120-22. Rowe sent a letter to Hoover on October 30, 1928 expressing himself "so thoroughly convinced of your election that I am submitting at this time a suggestion which I hope may have your favorable consideration...[that if] after your election to the Presidency, and prior to your Inauguration, you would make a tour of South America, it would mean a great service to our country and have a far-reaching influence on our relations with Latin America." Rowe followed this with a similar letter on the day of Hoover's election (November 6, 1928). See L.S. Rowe to Herbert Hoover, October 30, 1928 and L.S. Rowe to Herbert Hoover, November 6, 1928, both in Campaign and Transition File, Box 170, Herbert Hoover Presidential Library, West Branch, Iowa.

${ }^{28}$ See DeConde, Herbert Hoover's Latin-American Policy, 14.

${ }^{29}$ On earlier presidential visits to Latin America, Theodore Roosevelt famously visited Panama in late 1906 to observe construction of the Panama Canal. It marked the first time a U.S. president left the country during his time in office. See McCullough, The Path Between the Seas: The Creation of the Panama Canal, 1870-1914, 492-502. Calvin Coolidge visited Havana, Cuba in 1928 to address the Sixth International Conference of American States.

${ }^{30}$ Hoover made the visit at the suggestion of Leo S. Rowe, Director General of the Pan-American Union. See Rowe to Hoover, October 30, 1928 and November 6, 1928, Campaign and Transition File, Box 170, Herbert Hoover Presidential Library, West Branch, Iowa.

${ }^{31}$ DeConde, Herbert Hoover's Latin-American Policy, 15.
} 
At each of its eleven stops throughout Central and South America, events on the goodwill tour were carefully orchestrated to reinforce the president-elect's public message. ${ }^{32}$ Civilian personnel accompanying Hoover were reminded en route, for example, that all individuals in the party - whether trained as diplomats or not - had "more power than they realize[d]" to affect Latin American perceptions of the United States because of the “psychological moment” at which the visit was occurring. Hoover's designs for Latin America policy were already well-known, and, the traveling party's instructions said, the moment was ripe for Latin Americans who held unfavorable views of the United States to begin to change their attitudes. As a tour intended to shift public perceptions about the United States, the mission was to communicate Washington's good intentions. Accordingly, members of the traveling party were further encouraged to "forget your reticence when handing out complements" to the Latin American peoples they encountered; to "leave out of your conversation all...mention or suggestion of the relative importance, degree of progress or even scenic value" of the United States; to either forget or "at least have the decency to hide" any "nigger-white man attitude of superiority" toward darker-skinned Latin American peoples; and to take care to refer to themselves as "norte-Americano" rather than as “Americans." (Latin Americans were "also Americans and proud of it," members of Hoover's party were reminded.) Displays of "courtesy and tact" by each member of the party would go a long way toward demonstrating respect for Latin America at the individual level, it was hoped, and would help reinforce Hoover's broader point that the United States desired to be thought of as a good neighbor to Latin America. Moreover, good conduct

\footnotetext{
${ }^{32}$ Hoover's itinerary included eleven stops in ten countries. In order, he visited El Salvador, Honduras, Nicaragua, Costa Rica, Ecuador, Peru, Chile (where he made two stops - one in Antofagasta and one in Valparaiso), Argentina, Uruguay, and Brazil. See "An Incomplete Itinerary of Herbert Hoover's 1928 South American Trip," Campaign and Transition File, Box 164, Herbert Hoover Presidential Library, West Branch, Iowa.
} 
would help underscore that North, Central, and South America shared "identical interests along many lines." 33 This awareness that each person in the traveling party had a critical role to play in helping to carry Hoover's (and by extension, the United States') message to Latin American peoples at an individual level foreshadowed a central premise of U.S. goodwill cruising in Latin America throughout the "good neighbor" years: individuals outside the traditionally narrow realm of "diplomacy" could and would assume roles critical to the success of foreign relations.

As highly visible symbols of American power, U.S. naval vessels and personnel were also expected to do more on the tour than merely offer the president-elect a safe and reliable form of transportation. Naval assets - both vessels and personnel - were to play an active role in communicating his good neighbor message, just as civilian personnel were. It was a remarkable turnabout for the Navy, considering that over the years, in Latin American eyes, American ships had become symbols of U.S. heavy-handedness. Nevertheless it was a role that Navy leaders, responsive to the direction of national policy, quickly embraced. Just as Hoover was preparing to leave California, Navy Secretary Curtis D. Wilbur issued a change in departmental policy that for the first time recognized the "cultivation of friendly relations with foreign peoples" among the major objectives of U.S. naval operating forces. ${ }^{34}$ It was a recognition that while Hoover and his civilian entourage would seek to foster goodwill and

\footnotetext{
${ }^{33}$ Unknown author, "MISSION - OF TOUR" (undated), Campaign and Transition File, Box 170, Herbert Hoover Presidential Library, West Branch, Iowa.

${ }^{34}$ Secretary of the Navy, Annual Report of the Secretary of the Navy for 1928, November 15, 1928. H. Doc. No. $366,70^{\text {th }}$ Cong., $2^{\text {nd }}$ Sess. (1928), 3. Cultivating friendly relations with foreign peoples did not show up as an objective of U.S. naval operating forces in prior reports of the Secretary of the Navy in the 1920s. For example, in 1927 the Secretary's annual report listed the objects of naval operating forces as 1) maintaining the U.S. fleet in a state of readiness, 2) protecting Americans in the Far East and Central America, and 3) the maintenance of the European and Near East Squadron. See Secretary of the Navy, Annual Report of the Secretary of the Navy for 1927 , November 1927 . H. Doc. No. $81,70^{\text {th }}$ Cong., $1^{\text {st }}$ Sess. (1927). According to annual reports of the Secretary of the Navy, "cultivation of friendly relations with foreign peoples" continued to be a formal objective of U.S. naval operating forces through the end of Hoover's term in late 1932.
} 
change Latin American attitudes at the individual level, the Navy would reinforce the "good neighbor" message at the macro level. Its large, grey ships were among the most modern and powerful in the world, and, U.S. foreign policymakers believed, in delivering Hoover rather than landing parties of U.S. Marines, they would do much to help change Latin American attitudes conditioned by years of heavy-handed U.S. armed interventionism. Similarly, the ships' uniformed crews were well-positioned to play a symbolic part. Unlike the menagerie of civilian individuals who accompanied the president-elect, U.S. sailors were, quite literally, uniformly clothed in the garb of American power. Naval vessels and personnel would both, therefore, form a nice complement to the president-elect by visibly reinforcing his good neighbor message.

The Navy's unique diplomatic attributes made it well-suited to the task of boosting what U.S. foreign policymakers repeatedly referred to as American "prestige" in the hemisphere. To understand the symbolism of naval power, and its linkage to national prestige, it is again useful to turn to the work of naval theorist Ken Booth. "Prestige," Booth argues, is "the sex appeal of politics among nations." Booth's conception is apt because it recognizes that prestige is a difficult thing to quantify or discuss in absolute terms. The only evidence of its existence is, as he suggests, the behavior of nations under its sway. A nation possessing prestige, he argues, is "listened to [by other nations] with more than diplomatic courtesy," and its words are "invested with a special credibility and authority." Respect of this sort cannot be demanded or accrued under threat of force, Booth cautions. Rather, it must be painstakingly cultivated by repetition of friendly activities that build confidence. ${ }^{35}$ Hoover's goodwill tour depended on the U.S. Navy to do exactly that: to be seen by large

${ }^{35}$ Booth, Navies and Foreign Policy, 50-51. 
numbers of Latin American peoples in port after port as a symbol of U.S. goodwill as it delivered the chief spokesman, Hoover, for Washington's new approach to Latin America. As the tour's planners recognized, the Navy's role would be to help the United States gain "additional prestige through the showing of a smart naval force" in ports throughout Central and South America. ${ }^{36}$

As Hoover's tour progressed from early stops in Central America to the west and east coasts of South America, observers including the president-elect himself spoke glowingly of the benefits of having the Navy engage in such goodwill visits. For example, having witnessed the enthusiastic receptions given Hoover by large crowds in port after port, Chicago journalist Edward Bell Price (who accompanied Hoover on the entire journey) asked a rather straightforward question in a column published the U.S.S. Utah's ship newspaper, The Big U: "Why not consciously make the United States Navy an arm of American diplomacy?" Allowing that the Navy existed first and foremost "for the purposes of war," Price argued that naval vessels and personnel had nonetheless rendered valuable assistance to the changing U.S. policy in South America, and had helped "reinforce the influences of peace." The Navy had, so far, borne Hoover through Latin American waters "with dignity" and had provided "invaluable" assistance in making the "great enterprise" of the goodwill tour a success. Its personnel were, in Price's view, perfect candidates for diplomatic duty. The Utah's officers were "splendid," he wrote - both educated and refined - and they commanded "magnificent" vessels. "Is this not sea power - war power - active beneficently in the spheres of diplomacy and peace?" he asked. It was just the kind of activity that the Navy should be conducting "systematically and regularly," Price believed. Were it up to

\footnotetext{
${ }^{36}$ Unknown author, "MISSION - OF TOUR" (undated), Campaign and Transition File, Box 170, Herbert Hoover Presidential Library, West Branch, Iowa.
} 
him, he concluded, U.S. naval vessels and personnel would be seen "carrying the Stars and Stripes frequently into the harbors of sister nations, big and little, and using all their disciplinary efficiency and culture in spreading acquaintance with the United States of North America and its ideals of democracy in politics, social equality, and that doctrine...which sets a common value upon the prosperity of every country on the globe." ${ }^{37}$

Price's sentiments about the promise of goodwill naval diplomacy echoed those expressed by another American reporter, Harry W. Frantz, in the Christmas Day 1928 issue of The Catapult, the ship newspaper of the U.S.S. Maryland, which had borne Hoover from San Francisco to Central America and then down the South American west coast. The president-elect and his party had left the Maryland for the overland trip from Chile to Argentina with "a keen realization that the Navy's handclasp of friendship had been as warm and genuine as Latin America's 'abrazo' of affection,” Frantz wrote. Although Hoover's goodwill tour had taken place "in the shadow of sixteen-inch guns and other amazing contrivances of modern warfare," he wrote to all on board, the Maryland "seemed essentially a 'peace ship', a meeting place of men capable of fighting their country's battles with bighearted hospitality and friendly words as well as, when necessary, with gunpowder and steel." To the proud history of the Maryland's exploits in battle must be added, Frantz, accounts of its quarterdeck "as the scene of friendly international luncheons, as a center for [the] amicable conversations of diplomats, and as a peaceful haven for newspaper correspondents. ${ }^{\prime 38}$

\footnotetext{
${ }^{37}$ Edward Bell Price, "Our Naval Men as Diplomats," The Big U (ship newspaper of the U.S.S. Utah), December 22, 1928. Located in Campaign and Transition File, Box 171, Herbert Hoover Presidential Library, West Branch, Iowa.

${ }^{38}$ Harry W. Frantz, "President-Elect Leaves at Valparaiso," The Catapult (ship newspaper of the U.S.S. Maryland), December 25, 1928. Located in Lou Henry Hoover Papers, Box 110, Herbert Hoover Presidential Library, West Branch, Iowa.
} 
It was a conclusion shared by the Maryland's crew. Goodwill cruising was indeed a fruitful endeavor for the Navy, the Catapult editorialized in the same issue. It cost the Navy "only the trouble of expressing it," and returned benefits for the nation that had "a value beyond conversion to material terms." It helped foster respect and "national prestige" - both diplomatic necessities that "each country must earn for itself." The respect and prestige of the United States throughout Latin America could only be earned, the editorial continued, by a "genuine friendliness of outlook coupled with fairness toward other nations." Such work, it concluded, was "not a matter for the State Department alone" but was a shared responsibility. Goodwill diplomacy was the work of "every citizen," the idea being that individuals owed it to their country "to represent it well" in contacts with foreigners by demonstrating courtesy, tact, and respect. To this end, the editorial urged, the U.S. Navy had a vital, ongoing role to play. In the new age of good neighbor diplomacy, the work of the Navy must range far beyond its traditional vocation of preparing for war. Each sailor was "something...of an unofficial diplomat" who, when abroad, garnered "somewhat closer observation" than civilians or diplomatic personnel. Unlike traditional diplomats, Navy personnel were "labeled" by their uniforms and mode of transport as representatives of American national power, the Catapult concluded. In practice this meant that naval personnel were routinely "seen seen more by foreigners than the average [American] citizen."39

Just as the journey alerted the U.S. Navy to the productive role it could play in the nation's policy toward Latin America, so too did it open Hoover's eyes to the utility of goodwill naval diplomacy. According to reports filed by newspaper reporters traveling with him, the president-elect's choice to make the trip on board naval ships rather than

\footnotetext{
39 "The Good Will Business," The Catapult (ship newspaper of the U.S.S. Maryland), December 25, 1928. Located in Lou Henry Hoover Papers, Box 110, Herbert Hoover Presidential Library, West Branch, Iowa.
} 
commercial vessels was a strategic one intended, in part, to boost the Navy's peacetime diplomatic mission. ${ }^{40}$ From early in his voyage, Hoover often expressed satisfaction that, through greater engagement in goodwill cruising, the Navy could help the United States foster closer, more cooperative relations with foreign countries. On numerous occasions, the New York Herald Tribune reported, the president-elect expressed the hope that, with this goal in mind, goodwill naval cruises abroad would be "more heavily emphasized in the future." Hoover's enthusiasm reached its peak as his tour wound down and began its homeward voyage to Hampton Roads, Virginia. At a banquet with the captain and crew of the U.S.S. Utah on Christmas night, 1928, Hoover told his hosts that his goodwill tour had been "a revelation in many ways of the versatility and skill of naval men in a thousand things not pertaining to war." Such goodwill diplomatic activity had far-reaching benefits that were difficult to overestimate, he continued. In his view, goodwill cruising of the sort that had occupied the Navy during his tour was the "highest peace-time function of the fleet." They were the types of activities in which the Navy should "always will be engaged." specific terms, Hoover acknowledged the diplomatic value of having naval personnel carry out such duty. The role played by "naval men" ashore was one of the "main factors" in the goodwill tour's success, the New York Times quoted Hoover as saying. ${ }^{42}$ During his stop in Rio de Janeiro, Brazil, the president-elect trumpeted the importance of personal contacts

\footnotetext{
${ }^{40}$ Edwin S. McIntosh, "Hoover Favors Use of Navy in Peace Missions: Tells Utah Officers Ships Can Give Invaluable Aid in Promoting Friendships," New York Herald-Tribune, December 28, 1928.

${ }^{41}$ No copy of Hoover's remarks aboard the Utah exists in either the Campaign and Transition Files or the Lou Henry Hoover Papers at the Hoover Presidential Library. I have had to rely on press coverage to reconstruct his remarks. Hoover's remark on far-reaching benefits comes from Edwin S. McIntosh, "Hoover Favors Use of Navy in Peace Missions: Tells Utah Officers Ships Can Give Invaluable Aid in Promoting Friendships," New York Herald-Tribune, December 28, 1928. Hoover's expressed hope that the Navy would continue engaging in goodwill cruising comes from L.C. Speers, "Messages to Utah Forewarn Hoover," New York Times, December 27, 1928.

${ }^{42}$ L.C. Speers, "Hoover Extols Part of Navy in Mission,” New York Times, December 28, 1928.
} 
between peoples of different nationalities as the key to achieving a "better understanding" among nations. Only through such one-to-one contacts, he urged, could one country "gain a real insight into the character of the people of the other. ${ }^{, 43}$ Edwin McIntosh, the Herald Tribune reporter who publicized Hoover's remarks, wrote further that Hoover's vision met with the approval of naval officers who were "eager to have their field of service to the nation broadened." "Perhaps no body of men represents a fairer cross-section of North American intelligence, education and integrity," McIntosh concluded, "than the officers and men of the United States Navy."

Hoover's pre-inaugural embrace of the concept laid the groundwork for the active goodwill cruising regimen the U.S. would pursue in the 1930s. After expending years of effort trying to impose order in Latin America through gunboat diplomacy interventions, in the late 1920s and early 1930s under Hoover and his successor, Franklin D. Roosevelt, Washington sought instead to cultivate order through conciliatory actions. As the Christian Science Monitor concluded near the end of Hoover's goodwill tour, the task for U.S. policy during these transitional years became one of turning the page on the interventionist past and "selling" the United States anew to Latin America. For years, the Catapult noted, Latin Americans had come to the conclusion - not unjustifiably - that their norteamericano neighbors were "materialistic" and "imperialistic," while, for their part, Americans were all too content to let those perceptions develop unchallenged. What Hoover's trip demonstrated, the paper argued, was that there were dividends to be earned by disseminating what it called

\footnotetext{
${ }^{43}$ Edwin S. McIntosh, "Hoover Favors Use of Navy in Peace Missions: Tells Utah Officers Ships Can Give Invaluable Aid in Promoting Friendships," New York Herald-Tribune, December 28, 1928.

${ }^{44}$ Edwin S. McIntosh, unedited dispatch sent to New York Herald Tribune, published in The Big U: Evening Bulletin, December 27, 1928. Located in Lou Henry Hoover Papers, Box 110, Herbert Hoover Presidential Library, West Branch, Iowa.
} 
a "truer conception" of the United States throughout the hemisphere - one that minimized economic factors and instead sought to shine the spotlight on U.S. values and cultural achievements while at the same time demonstrating a sincere American interest in those emanating from Latin America. It was "vital" that the work begun by Hoover be expanded and continued, the paper concluded, if the United States hoped to change Latin American attitudes. $^{45}$

\section{UNDER FDR: THE U.S. NAVY AS A GOOD NEIGHBOR}

The economic calamity of the Great Depression hijacked Hoover's presidency and relegated foreign policy to the periphery of his overall policy agenda. By extension, it dashed any hopes for an active program of goodwill naval cruising in support of changing U.S. policy toward Latin America. The election of Franklin D. Roosevelt to the presidency in 1932 breathed new life into U.S.-Latin American relations, as the new president embraced the idea of selling U.S. good neighbor intentions to Latin America. To Roosevelt, a former Assistant Secretary of the Navy, it was only natural to employ the Navy in this capacity. In May 1933 Roosevelt's new Navy Secretary, Claude Swanson, approved a change to U.S. naval policy more sweeping than the one put into effect by his predecessor, Wilbur, before Hoover's goodwill tour. Where the policy under Hoover had made "cultivation of friendly relations with foreign peoples" an objective of the U.S. Navy's operating forces, Swanson's

\footnotetext{
${ }^{45}$ In making the case for continuing the work of Hoover's goodwill tour, the paper quoted Dr. Francisco Chigliani, editor in chief of the Montevideo, Uruguay daily newspaper El Dia, who asked the following of American reporters accompanying Hoover on his voyage: "Are we to understand that all North Americans are divorcees, are criminals? That all your music is jazz? Is this the United States? When we turn on our radios or read your papers and cables or see your 'movies' that is the impression we get. About your great cities, your marvelous cultural sciences, educational and social progress we hear little or nothing. You journalists must have your hearts and heads and hands to making your real country and its people known to us Latin Americans. Through such enlightenment will come real rapprochement and understanding." See "Good-Will Tour Shows Need to 'Sell' America: Hoover Party Finds Active Publicity Required to Meet Hostile Efforts," Christian Science Monitor, December 27, 1928.
} 
change made an explicit commitment "to make foreign cruises to cultivate friendly international relations" (emphasis added). ${ }^{46}$

Under Roosevelt the U.S. Navy quickly became a fixture in Latin American waters, engaging in numerous cruises aimed specifically at bolstering a "good neighbor" image of the United States. The pattern began to emerge clearly in 1934 , when, in response to the administration's new emphasis on Latin America and in recognition of the Navy's own peacetime mission of "showing the flag" in foreign ports, Navy leaders began routinely sending newly constructed ships on their trial voyages (known in Navy parlance as "shakedown cruises") to Latin American ports. The seminal event in this regard was the launch of the U.S.S. Ranger, the first U.S. naval ship designed and built from the keel-up as an aircraft carrier. ${ }^{47}$ When the Ranger departed Hampton Roads, Virginia for a lengthy shakedown to Rio de Janeiro (Brazil), Buenos Aires (Argentina), and Montevideo (Uruguay) in August 1934, its itinerary was packed not only with the full battery of on-board equipment trials and qualifying tests that were routine for such journeys, but with a full complement of public diplomacy activities as well. Navy leaders had initially expressed concern at sending the Ranger on such a long proving voyage, preferring instead to have the vessel remain closer to home in the Gulf of Mexico. ${ }^{48}$ But the ship's newly appointed commanding officer, Arthur L. Bristol (Captain, U.S. Navy), who had served in the U.S. naval mission to Brazil

\footnotetext{
46 “U.S. Naval Policy,” approved May 10, 1933, RG 59, File 811.30/177, National Archives.

${ }^{47}$ Prior to the Ranger, the U.S. Navy had converted existing ships into aircraft carriers, but had not designed and built a vessel specifically for the purpose of carrying, launching, and landing Navy aircraft at sea. For more, see Robert Cressman, USS Ranger: The Navy's First Flattop from Keel to Mast, 1934-46, 1st ed. (Washington, D.C.: Brassey's, 2003). Cressman's study of the Ranger, from conception to retirement, provides an excellent overview of the ship's history. See also Baer, One Hundred Years of Sea Power: The U.S. Navy, 1890-1990, $140-41$.

${ }^{48}$ Cressman notes that, initially, Navy leaders feared that "lengthening the Ranger's cruise would limit the operations that the carrier could conduct prior to her final acceptance trials" and "did not look favorably upon the extension."
} 
earlier in his career and was familiar with Latin American affairs, prevailed upon the Navy's Bureau of Aeronautics to let the vessel venture further south. A shakedown cruise down the east coast of South America, he argued, would allow the ship to undergo more extensive tests of its mechanical systems while at the same time affording the ship's crew a valuable opportunity to visit "a large foreign port south of the Equator." As Robert Cressman has argued, the Bureau's approval of the more ambitious itinerary, including stops in Argentina and Uruguay as well as Brazil, signaled that the Navy had a desire to help the State Department promote the president's Good Neighbor Policy. ${ }^{49}$

Upon its completion, leaders in both the Navy and State Departments applauded the Ranger's shakedown cruise as an unqualified success. Not only had ship and crew been successfully put through their technical and training paces, officials in the two departments noted approvingly, the cruise's three stops had also "created a favorable impression and [had] been of benefit to American prestige. ${ }^{, 50}$ So impressed were State and Navy Department leaders that they sought to replicate the Ranger's success. In three key ways its itinerary became a blueprint for future goodwill cruises in Latin American waters. First, as they had done during President Hoover's goodwill tour, during the Ranger's shakedown cruise naval personnel engaged in highly public demonstrations of respect for the sovereignty of the visited nations. For example, at Rio de Janeiro, Captain Bristol sent a small detachment of sailors and Marines ashore, including a marching band, to participate in a parade honoring Brazil's Independence Day - a move that, after the fact, occasioned a formal note of thanks

\footnotetext{
${ }^{49}$ Quoted in Cressman, USS Ranger: The Navy's First Flattop from Keel to Mast, 1934-46, 16.

${ }^{50}$ Commanding Officer, U.S.S. Ranger (Bristol) to Chief of Naval Operations, "U.S.S. Ranger - Shakedown Cruise - Report of Operations, 17 August to 5 October," October 1, 1934, RG 80, File CV4-A4(3), Box 1640, National Archives.
} 
from the Brazilian Foreign Office. ${ }^{51}$ During the ship's stop in Buenos Aires, Bristol laid wreaths at a monument to José de San Martin, a hero of Argentina's war for independence from Spain, and at a monument to the nation's foremost naval hero, Almirante William "Guillermo" Brown, whose naval victories during Argentina's war for independence won him acclaim as a founding father of the Argentine Navy. ${ }^{52}$ And in Montevideo, Bristol again paid public homage to a Latin American national hero by laying a wreath at the tomb of General José Gervasio Artigas, a key figure in the history of Uruguayan independence. The wreath he laid at the Artigas monument featured a ribbon consisting of the intertwined colors of the U.S. and Uruguayan flags, and bore an inscription reading "Homage of the Navy of the United States of America." It was just the kind of good neighbor message Roosevelt's larger policy was designed to send, and it was no doubt reinforced by the salute Bristol and six of his officers rendered at the tomb "for an appreciable period of time" in the presence of "a large number" of Uruguayan military personnel and civilian observers. ${ }^{53}$

Also foreshadowing the standard practice of future goodwill cruises, at each stop U.S. authorities sought to maximize the Ranger's visibility and that of her crew before the public. By the early 1930s, after more than three decades of active U.S. intervention in Central America and the Caribbean, U.S. naval vessels had become symbols of a gunboat diplomacy reviled throughout Latin America. Thus changing Latin American perceptions of U.S. naval power would be central to cultivating warmer feelings in Latin America toward the United

\footnotetext{
${ }^{51}$ See Commanding Officer, U.S.S. Ranger (Bristol) to Chief of Naval Operations, "U.S.S. Ranger Shakedown Cruise - Report of Operations, 17 August to 5 October," October 1, 1934, RG 80, File CV4-A4(3), Box 1640, National Archives. See also U.S. Ambassador to Brazil to Secretary of State, September 27, 1934, RG 59, File 811.3310/437, National Archives.

${ }^{52}$ See Commanding Officer, U.S.S. Ranger (Bristol) to Chief of Naval Operations, "U.S.S. Ranger Shakedown Cruise - Report of Operations, 17 August to 5 October," October 1, 1934, RG 80, File CV4-A4(3), Box 1640, National Archives. See also Scheina, Latin America: A Naval History, 1810-1987, 1-8.

${ }^{53}$ U.S. Chargé d'Affaires in Uruguay (Dominian) to Secretary of State, September 24, 1934, RG 59, File 811.3310/438, National Archives.
} 
States. From the itinerary the Navy and State Departments drew up for the Ranger's shakedown cruise, it was clear that leaders in both agencies believed it necessary to expose as many people as possible in each port to U.S. naval vessels and personnel engaged in friendly missions. The executive officer of the Ranger, for one, recognized the nature of the task. "We now have before us another job, a harder and more exacting one than those which have gone before," Commander Charles Pownall wrote to his crew in the first edition of the ship's newspaper: "The job is a diplomatic one in which we meet people of other lands and tongues." Demonstrating a firm grasp of the performance aspect of the Ranger's business, he beseeched his men to remember that "we are on parade before their [Latin Americans'] eyes and are required to inculcate confidence and respect not only to us but as representatives of American citizenship at its best. ${ }^{, 54}$ It was a message almost identical in spirit to the one that had guided the Hoover goodwill tour in late 1928: each individual was an emissary of the United States as a whole, and had to act accordingly.

While exposing locals to the Ranger's crew on an individual level would be important to the goodwill mission, planners recognized, it was also essential to maximize locals' contact with the ship itself. Accordingly, in all three ports the Ranger's crew made arrangements to permit the general public to come aboard. To manage the crowds they distributed a large but limited number of visitor passes, as American ships had long done on visits to large U.S. ports such as New York, where naval vessels were often objects of great public curiosity. In Rio de Janeiro, the first port visited, the crowds were small. Out of an abundance of caution, Captain Bristol had ordered the Ranger to anchor more than a mile from shore - out in the middle of the city's deep natural harbor. While this minimized the

\footnotetext{
${ }^{54}$ Quotes from ship newspaper, The Ranger, contained in Cressman, USS Ranger: The Navy's First Flattop from Keel to Mast, 1934-46, 20.
} 
risk of damage from moving in shallow water closer to shore, it also made public access to the ship - and hence, public diplomacy - a difficult proposition. In practice this meant that throughout the Ranger's eleven-day stay in Rio, the only locals who got to visit the ship were invited VIP's and those few general visitors who either owned their own boats or could catch a ride in one of the small boats ferried back and forth by the ship's crew from ship to shore. ${ }^{55}$ It was a situation that raised the ire of U.S. Ambassador Hugh Gibson, who decried Captain Bristol's decision to decline an urban, pier-side mooring. It was an unfortunate decision, he wrote to Secretary of Cordell Hull, one that ensured that the Ranger's visit was "little noticed" by the Brazilian press and public. ${ }^{56}$

It was an error that the State Department, eager for the Ranger to make a positive impact in South America, would not allow to be repeated. To have a shot at moving public opinion in favor of the United States, the ship would have to be close and accessible to the local populations. At the State Department's insistence, in approaching its next port, Buenos Aires, the Ranger would traverse the narrow, shallow Indio Channel in order to reach a berth close to one of the city's open plazas where thousands had gathered to witness its arrival. ${ }^{57}$

\footnotetext{
${ }^{55}$ Description of the ship's anchorage in the harbor of Rio de Janeiro, and of visitors to the ship, is contained in Bristol's after-action report on the shakedown cruise. Although he wrote that a "large number" of visitors came aboard during the Ranger's stay in Rio de Janeiro, the number almost certainly pales in comparison to those that came aboard in Buenos Aires and Montevideo. Bristol notes that in those latter two cities, his crew distributed twenty-five thousand visitor passes in Buenos Aires and "something short of twenty thousand in Montevideo." See Commanding Officer, U.S.S. Ranger (Bristol) to Chief of Naval Operations, "U.S.S. Ranger - Shakedown Cruise - Report of Operations, 17 August to 5 October," October 1, 1934, RG 80, File CV4-A4(3), Box 1640, National Archives.

${ }^{56}$ U.S. Ambassador to Brazil (Gibson) to Secretary of State, September 11, 1934, RG 59, File 811.3310/430, National Archives.

${ }^{57}$ Although he embraced the diplomatic nature of the Ranger's assignment, it is clear from Captain Bristol's after-action report that he opposed bringing the Ranger close to shore in Buenos Aires and Montevideo. He reported that "it was with some trepidation that the Indio channel was approached...Information received by radio on approaching the channel, indicated a depth of twenty-eight feet. The RANGER's draft at this time was just over twenty-five feet. It may be noted here, that it would have been impossible for the RANGER to have entered the channel at any time during the week previous; A northwest wind had been blowing and the channel depth had been as low as nineteen feet. As a matter of fact, this depth of nineteen feet existed up until the late afternoon of the day before our entry A shift of wind to the southeast had caused the rapid deepening of the
} 
An estimated twenty-five thousand visitor cards were issued in Buenos Aires and another twenty-thousand during the Ranger's subsequent visit to the nearby Uruguayan capital of Montevideo, where the Ranger also sidled up to an urban pier in full view of large crowds. In each case, Bristol wrote in his after-action report, bringing the ship so near the crowds presented an "extremely difficult" situation in which crowd control was "difficult to exercise." Not all who wanted to visit the ship could be accommodated, and in both cities high demand led to the appearance of counterfeit visitor passes as well as the emergence of shadow market in which passes (which were originally distributed free of charge) were bought and sold in the streets. In both ports the ship's proximity to the public made the Ranger's crew's job more difficult. Yet from a policy point of view, the State Department judged the rewards of the added effort to be worth the trouble. American diplomats in all three countries praised the conduct of the Ranger's crew in port and underscored the diplomatic value of the ship's visit. The U.S. Chargé d'Affaires in Uruguay, Leon Dominian, wrote to Washington that the Ranger's visit marked the first occasion in which such a large contingent of American sailors (numbering more than nine-hundred) spent six successive days in port in the heavily-touristed city of Montevideo "without giving rise to a single case of disorderliness.” And Captain Bristol, despite misgivings about the wisdom of forcing the Ranger to enter the port of Buenos Aires through the Indio Channel, concluded that its visits to all three cities had "created a favorable impression and have been of benefit

channel." In the end, he concluded, it was his "considered opinion that the visit should not be repeated by a ship of this size." See Commanding Officer, U.S.S. Ranger (Bristol) to Chief of Naval Operations, "U.S.S. Ranger - Shakedown Cruise - Report of Operations, 17 August to 5 October," October 1, 1934, RG 80, File CV4-A4(3), Box 1640, National Archives. 
to American prestige and indirectly to American business." ${ }^{, 58}$ Had he tried, Bristol could scarcely have written a clearer statement of Roosevelt's goals for the Good Neighbor Policy.

While they emphasized public displays of respect and sought to maximize the Ranger's visibility and that of her crew, American foreign policymakers had a third purpose in mind in routing the Ranger's shakedown cruise to South America: they wanted the Ranger - the newest, most complex, most modern ship in the U.S. inventory (and the technological marvel of its day) - to serve as a shining example of the ingenuity, development, and strength of the United States. Ultimately, it was this line of thinking, as well as the availability of a steady stream new American ships in need of testing (courtesy of President Franklin Roosevelt's new naval building program), that led U.S. policymakers to expand the use of shakedown cruises for diplomatic purposes throughout the "Good Neighbor" era. ${ }^{59}$ Routinely sending its newest, most advanced ships to Latin America to foster goodwill, they believed, could do much to help the United States put its best foot forward there. In 1934, the hope was that as the Ranger and her crew advertised

\footnotetext{
${ }^{58}$ Ibid.

${ }^{59}$ Very early in his first term, Roosevelt supported a naval building campaign that would both contribute to the all-important goal of national economic recovery and build the U.S. Navy up to quantitative and qualitative parity with Japan. As Robert Dallek notes, in June of 1933 Roosevelt allocated \$238 million in public works funds for the construction of thirty-two naval ships totaling 120,000 tons. It was the largest naval building campaign since 1916. And, as naval historian Kenneth Hagan notes, it was controversial: even among Roosevelt's closest political allies, the Keynesian notion of using government spending to stimulate economic growth had not yet taken firm root. Moreover, many liberals continued to be suspicious of arms manufacturers, believing that greedy arms dealers had helped lead the United States into World War I. As Hagan concludes, "The limited expansion of the navy in this milieu of Depression, isolationism, and pacifism testified to Franklin Roosevelt's political legerdemain." See Dallek, Franklin D. Roosevelt and American Foreign Policy, 19321945: With a New Afterword, 75-76. See also Hagan, This People's Navy: The Making of American Sea Power, 281-84. Naval historian Stephen Howarth describes Roosevelt's naval building program in greater detail. In addition to establishing one of the signature elements of Roosevelt's early "New Deal," the National Industrial Recovery Act of 1933 provided for the construction of four cruisers, two aircraft carriers, four flotilla leaders, sixteen destroyers, four submarines, and two gunboats over three years. And he notes that the Vinson-Trammell Act of March, 1934 gave the U.S. Navy "its first systematic program of ship replacement: a carrier, two cruisers, fourteen destroyers, and six submarines for 1935; fifteen destroyers and another six submarines for 1936; two battleships, twelve destroyers, and a further six submarines for 1937; and for 1938 and '39, two battleships, eight destroyers, and four submarines per year." See Howarth, To Shining Sea: A History of the United States Navy, 1775-1991, 357-58.
} 
Washington's "good neighbor" bonafides, it would also showcase the vitality of the Depression-ridden United States and garner all-important "prestige." A cutting-edge tool of the still relatively new field of naval aviation, the Ranger was particularly well-suited for this purpose. Before the Ranger even left the United States, the State Department had expressed the hope that its commander would put the ship's raison d'etre on public display by staging regular aviation demonstrations at each point along its journey. Showcasing its aviation capabilities would be such an important part of the Ranger's public diplomacy mission in South America, U.S. Ambassador to Brazil Hugh Gibson thought, that he asked Secretary of State Cordell Hull to press the Navy Department to permit the vessel to sail with a "full complement" of airplanes for just that purpose. However, as they had been more generally, Gibson's hopes for this particular aspect of the Ranger's visit to Rio were dashed. The Navy dispatched the ship with only seven planes on board, and those planes saw very little flight time in Rio owing to "almost continuous fog or haze with low ceiling." It was a stark contrast to the recent visit of a British aircraft carrier to Rio, during which its airplanes "carried out flying operations which made a deep impression and are still talked about." Gibson characterized the Ranger's lack of planes as a missed opportunity. ${ }^{60}$

Although aviation operations were impossible in the close, urban confines where the Ranger moored in Buenos Aires and Montevideo, U.S. diplomats still believed the ship succeeded in sending a message of American ingenuity, development, and strength. In Montevideo, U.S. chargé Dominian wrote, the "novel aspect" of the Ranger created "unusual

\footnotetext{
${ }^{60}$ Gibson wrote to Secretary of State Cordell Hull after the Ranger's departure from Rio that "It is a matter of regret that the RANGER came with only seven planes on board, although I had previously been informed as a result of inquiry made by the Department, that she would bring her full complement." See U.S. Ambassador to Brazil (Gibson) to Secretary of State, September 11, 1934, RG 59, File 811.3310/430, National Archives. For Captain Bristol's commentary on the Ranger's limited aviation operations in the harbor of Rio de Janeiro, see Commanding Officer, U.S.S. Ranger (Bristol) to Chief of Naval Operations, "U.S.S. Ranger - Shakedown Cruise - Report of Operations, 17 August to 5 October," October 1, 1934, RG 80, File CV4-A4(3), Box 1640, National Archives.
} 
interest" among the crowds who gathered nearby. The pier to which the carrier was moored was "constantly lined with thousands of spectators who stood for hours looking at the ship." Particularly gratifying was the fact that the British cruiser docked nearby, a smaller, nonaircraft carrying vessel, "created no such display of interest" among the locals. The crowds that gathered and gravitated to the Ranger provided evidence, he concluded, that "an admirable impression of American technical progress was left in this city." Importantly for the fostering of good neighborism, Dominian noted that the public impression seemed entirely "unconnected with the thought that the ship was a man-of-war." Rather, he wrote, the public interest was attributable to "admiration for the marvellous (sic.) technical progress exhibited by the aircraft carrier." ${ }^{, 61}$ It was the kind of message that the State Department's Latin America hands no doubt welcomed.

The Ranger's shakedown cruise was a turning point in U.S. policy in that it confirmed to both State Department and Navy leaders the wisdom of using naval vessels and personnel to cultivate goodwill in Latin American waters. Their upbeat analysis was amplified by the autumn of 1934 by evidence that the Roosevelt administration's efforts to sell its "good neighbor" intentions in Latin America had begun to pay dividends. Delegates to the Seventh International Conference of American States in Montevideo, Uruguay (December 1933) had welcomed, for example, Secretary of State Cordell Hull's surprising declaration that the United States would adhere to the assembly's agreement that "no state has the right to intervene in the internal or external affairs of another." ${ }^{, 2}$ Latin Americans also welcomed

\footnotetext{
${ }^{61}$ U.S. Chargé d'Affaires in Uruguay (Dominian) to Secretary of State, September 24, 1934, RG 59, File 811.3310/438, National Archives.

${ }^{62}$ Robert Dallek notes that Hull's move was significant, but not a complete repudiation of intervention. Hull, he notes, was determined "to preserve 'the right to protect lives and property where government has broken down and anarchy exists', and accordingly, "added the reservation that the United States expected the signatories to
} 
Washington's abrogation of the 1903 Platt Amendment that had long given the United States the right to intervene on the island and which, together with the 1904 Roosevelt Corollary to the Monroe Doctrine, had long been a flash point for anti-U.S. resentment throughout the hemisphere. In Peru, U.S. Ambassador Fred Dearing reported hearing "enthusiastic commendation" for the Roosevelt administration's move. "Even the most distrustful of our illwishers," he noted, "are beginning to believe the Good Neighbor is a reality." year, President Roosevelt accelerated the withdrawal of U.S. troops from Haiti, ending a nearly two-decade long occupation, and signaled his intent to find a new basis for cooperative relations with Panama, where, like Cuba, the United States had insisted upon a right of intervention since $1903 .{ }^{64}$

\section{BALANCING GUNBOATS AND GOODWILL: THE SPECIAL SERVICE SQUADRON}

The Ranger's South American cruise also confirmed for U.S. policymakers the specific wisdom of using shakedown cruises for goodwill purposes. Not only were new vessels such as the Ranger the best exemplars of American technological progress, they believed, but as brand new additions to the fleet they were also untainted by any association with the nation's interventionist past in Central America and the Caribbean. Therefore, it was thought, they could serve more credibly than others as emissaries of good neighborism

\footnotetext{
work out a codification or definition of the convention's terms." See Dallek, Franklin D. Roosevelt and American Foreign Policy, 1932-1945: With a New Afterword, 83.

${ }^{63}$ Dearing is quoted in Wood, The Making of the Good Neighbor Policy, 112. Of the Roosevelt administration's decision to abrogate the Platt Amendment, Wood writes on the same page that "It may be said that by 1933 the Platt Amendment, far from providing a desired right of intervention, had become for the United States a burdensome responsibility involving duties to maintain order which appeared not only incompatible with the Good Neighbor policy but also expensive and troublesome...The Platt Amendment had been a symbol of inequality, and its abandonment was an act, as distinct from a mere expression of intention, that quickened the appreciation of the Good Neighbor in other countries."

${ }^{64}$ Dallek, Franklin D. Roosevelt and American Foreign Policy, 1932-1945: With a New Afterword, 87.
} 
throughout Latin America. This emerging partiality toward shakedown cruises was in part a response to efforts by two commanders of the Special Service Squadron, Clark H. Woodward (Rear Admiral, U.S. Navy - formerly head of the U.S. Naval Mission to Peru) and Charles S. Freeman (Rear Admiral, U.S. Navy), to expand the geographical and substantive scope of that unit's operational responsibility. Upon assuming command of the Squadron in early 1933, Woodward appealed to the State Department to approve an ambitious schedule of goodwill cruising that would take its vessels far beyond their traditional Caribbean confines, to ports not only in nearby Colombia and Venezuela, but "down the west coast of South America" as well. ${ }^{65}$ Coming as it did during some of the deepest, darkest days of the Great Depression, and more than two months before Franklin Roosevelt proclaimed the "policy of the good neighbor" during his inaugural address, Woodward's proposal met with the same swift rejection that Ambassador Dearing's similar recommendation would the very next month. For the remainder of his brief tenure as its commander, the Special Service Squadron's ships would only venture from their base at Balboa, in the Panama Canal Zone, on brief excursions to other Panamanian ports. ${ }^{66}$

Weighing against any growth in the Squadron's mission throughout 1933 and 1934 was the fact that it was heavily committed in gunboat diplomacy pursuits as the United States

\footnotetext{
${ }^{65}$ Richard Millett argues that because the Special Service Squadron was created to serve an explicitly diplomatic purpose, throughout its brief, two-decade long existence the State Department exercised near total control over its operations. Donald Yerxa largely agrees, particularly with regard to the period after the U.S. abandoned interventionism and embraced the "policy of the good neighbor." On the issue of goodwill cruising, Yerxa notes, Navy-State tension over the Squadron's future "centered on State's desire to make the Special Service Squadron its own private naval force, operationally directed not by the squadron commander or CNO, but by State's Division of Latin American Affairs." See Millett, "The State Department's Navy: A History of the Special Service Squadron, 1920-1940."

${ }^{66}$ Yerxa, Admirals and Empire: The United States Navy and the Caribbean, 1898-1945, 87.
} 
moved to contain revolutionary unrest on the island of Cuba. ${ }^{67}$ During those two years the Special Service Squadron was expanded to more than thirty vessels (up from an average of between four and six) and engaged in patrol duty around Cuba. This duty represented the operational peak of the Squadron's gunboat diplomacy mission even though the United States never had to use its ships to land troops or engage in hostilities at sea. As stability returned to Cuba following the emergence of strongman Fulgencio Batista, permitting the United States to conclude the treaty abrogating the onerous Platt Amendment, it became clear to Navy leaders that, with interventionism in decline and good neighborism on the rise, the most active days of the Special Service Squadron's gunboat diplomacy were behind it. Still, a small movement emerged within the Navy dedicated to maintaining the Squadron's new high profile in U.S.-Latin American affairs.

As Washington's embrace of good neighborism grew, Woodward's successor, Freeman, who had played an active role in the Special Service Squadron's creation in 1920, began arguing that it should be given a broader role in the nation's diplomacy in Latin America beyond the Caribbean. ${ }^{68}$ In March 1934, well before the Cuban operation began to wind down and five months before the Ranger's shakedown cruise to South America helped crystallize the nation's new policy on goodwill naval diplomacy in Latin America, Freeman urged that the Squadron be used to conduct goodwill cruises in South American waters. It was important, he argued, that the U.S. Navy make efforts to counteract the British warships that routinely cruised there, and that the United States secure the long-term commercial

\footnotetext{
${ }^{67}$ For more, see Louis A. Pérez, Cuba: Between Reform and Revolution, 2nd ed., Latin American Histories (New York: Oxford University Press, 1995), 256-75.

${ }^{68}$ Special Service Squadron's founding mission quoted in Chief of Naval Operations to Commander, Special Service Squadron (COMSPERON), September 25, 1920. RG 80, Entry 13, Box 682, National Archives.
} 
advantages that were rightly the province of the United States. ${ }^{69}$ In January 1935, in the final days of operations around Cuba, Freeman pressed the Chief of Naval operations to give the Squadron a broader mission. Its role was "intimately tied up with our national policy," he wrote, and the question of its future was a basic one: should its assets continue to be confined to "such operations as emphasize their minatory function," as had been its "general practice" since its establishment? Rather than draw the unit down to pre-Cuba levels (four to six ships), as the Navy Department was contemplating doing, Freeman argued, Navy leaders should further boost its size and broaden its mission. The "single function" he had in mind was "showing the flag in Latin-America" and "improving prospects for U.S. commerce." Again he pointed to British efforts to make his case. The "American Squadron" of the Royal Navy was routinely engaged in Latin American cruises aimed at fostering goodwill, he cautioned. With its unique founding charge and the Roosevelt administration's emphasis on good neighborism, Freeman concluded, the Special Service Squadron was uniquely positioned to "parallel and neutralize" British efforts by taking on an ambitious schedule of goodwill visits throughout the Americas. ${ }^{70}$

\footnotetext{
${ }^{69}$ Commander, Special Service Squadron (COMSPERON) to Chief of Naval Operations, March 17, 1934, RG 80, Entry 22, Box 2196, National Archives.

${ }^{70}$ COMSPERON to Chief of Naval Operations (Restricted), "Resume of Special Service Squadron Activities, Period 7 November-31 December 1934," January 2, 1935, RG 80, Entry 22, Box 2195, National Archives. The appeal contained in Freeman's January 2, 1935 report was his most explicit, but he had made the case for a broader role for the Special Service Squadron on earlier occasions as well. On October 3, 1934 he wrote to the Chief of Naval Operations that "The obvious conclusion is that the presence of the Special Service Squadron in this particular area is strategically fortuitous in relation to the general Latin-American situation." And on November 7, 1934 he cautioned in vague terms that because "communistic efforts and Japanese trade expansion activities are confined to no particular area in Latin-America," the Squadron should be granted a broader authority than it had enjoyed in the past. See COMSPERON to Chief of Naval Operations (Restricted), "Resume of Special Service Squadron Activities, Period 21 August-2 October, 1934," October 3, 1934, RG 80, Entry 22, Box 2195, National Archives. See also COMSPERON to Chief of Naval Operations (Restricted), "Resume of Special Service Squadron Activities, Period 20 October-6 November 1934," November 7, 1934, RG 80, Entry 22, Box 2195, National Archives.
} 
For the most part, Freeman's appeals for a much broader role for the Special Service Squadron went nowhere. Throughout 1935 and 1936 he made numerous requests for permission to expand the Squadron's goodwill cruising beyond the Caribbean into South American waters. With only a few exceptions, the State Department denied each one. In 1935 Freeman received approval to take his flagship, the U.S.S. Trenton, on one cruise to the Colombian port of Cartagena, on the Caribbean, as well as a limited number of ports on the Pacific side of the isthmus of Panama: Buenaventura, Colombia, Guayaquil, Ecuador, and the Galapagos Islands. In each, the Admiral reported engaging his crew in goodwill activities such as public musical expositions, sporting competitions ashore, and a host of social functions. ${ }^{71}$ But that would be the extent of the Squadron's South American cruising on Freeman's watch. ${ }^{72}$ This is not to say that, under the Good Neighbor policy, the State Department was opposed in principle to the kind of broader goodwill cruising Freeman and his predecessor, Woodward, had proposed to undertake beyond the Caribbean. In the wake of the USS Ranger's highly successful shakedown cruise to Brazil, Argentina, and Uruguay, the State Department had clearly started getting on board with the idea. What diplomats objected to was using a unit so closely associated with past U.S. interventionism to do the job of cultivating goodwill in the hemisphere. As historian Donald Yerxa has argued, the Special Service Squadron suffered from an acute perception problem: its effectiveness as an

\footnotetext{
${ }^{71}$ The Navy forwarded copies of Freeman's after-action reports on these visits to the State Department. See Office of Naval Operations (Canaga) to State Department (George R. Merrell), July 10, 1935, RG 59, File 811.3310/575, National Archives.

${ }^{72}$ For several years following its June, 1935 visit to Buenaventura, Guayaquil, and the Galapagos, the Special Service Squadron's goodwill cruising would be limited to Central American countries, Caribbean islands, and the South American nations of Venezuela and Colombia with Caribbean coasts. In the spring of 1936, three ships of the Squadron (the Fairfax, Memphis, and Manley) visited Colombia and La Guaira, Venezuela. No other record of a Special Service Squadron visit to a South American nation exists in State Department files until 1938-39, when American fears of potential German and Japanese subversion in Latin America softened the State Department's opposition to allowing the Squadron to broaden its goodwill cruising agenda.
} 
instrument of gunboat diplomacy undermined its usefulness in doing goodwill naval diplomacy. In the end, the State Department judged, the Squadron could not easily shed its image and remake itself as an agent of good neighborism. ${ }^{73}$ The Navy had an important role to play in promoting the Good Neighbor Policy, but that role would be better filled by new vessels.

Following the Ranger's successful cruise in South American waters, the use of shakedown cruises for goodwill diplomatic purposes accelerated in South American waters. Almost immediately after the Ranger's return to the United States, the State Department approved the shakedown voyage of a new cruiser, the U.S.S. Tuscaloosa, with the same basic itinerary the aircraft carrier had followed. ${ }^{74}$ And in the wake of that cruise, officials from the State Department and Navy collaborated to send nine new ships on shakedowns to seventeen South American ports over the next three years. ${ }^{75}$ In each instance, the ships' itineraries were packed with activities of a highly public nature, and uniformly, U.S. foreign policymakers deemed the cruises successful in spreading the good neighbor message. All the while, the Special Service Squadron remained confined to the Caribbean.

\section{GOODWILL CRUISING IN PERU}

\footnotetext{
${ }^{73}$ Yerxa writes that "In the case of the squadron, the perception problem was acute. So often the instrument of coercion and intimidation, the force, except for late in its existence, rarely was perceived as the symbol of friendliness and good-neighborliness." See Yerxa, Admirals and Empire: The United States Navy and the Caribbean, 1898-1945, 89. Earlier, Yerxa wrote that the Squadron's "simultaneous pursuit of seemingly contradictory missions (goodwill cruising and gunboat diplomacy) was not entirely successful and gave the Special Service Squadron, like the foreign policy it attempted to implement, a schizophrenic character that it never completely shed.” Ibid., 83.

${ }^{74}$ The Tuscaloosa visited Buenos Aires, Argentina (November 2-12, 1934); Montevideo, Uruguay (November 13-20, 1934); and Rio de Janeiro, Brazil (November 23 - December 4, 1934). For summaries of these visits, see dispatches from U.S. diplomatic representatives to each country: RG 59, File 811.3310/454 (Argentina), File 811.3310/471 (Uruguay), and File 811.3310/467 (Brazil), National Archives.

${ }^{75}$ Totals calculated based on research in RG 59, File 811.3310, National Archives.
} 
By 1936 goodwill naval cruising had become a central feature of the Roosevelt administration's Good Neighbor Policy, and the U.S. Navy was becoming the public face of the United States in Latin America. The agenda soon expanded beyond shakedowns and ad hoc visits to include regular cruises by active elements of the U.S. Fleet. To policymakers in the Roosevelt administration, the growth of goodwill naval diplomacy was particularly good news for U.S. relations with Peru, which had been strained since Leguía’s 1930 overthrow. In an effort to boost ties with Peru and other nations on the South American west coast, in early 1936 Roosevelt proposed sending elements of the Scouting Force (a component of the U.S. Pacific Fleet) to visit ports on the west coast of South America following that year's annual training maneuvers off the Pacific coast of Panama. Navy Secretary Claude Swanson quickly signaled his agreement, informing the president that the Navy was prepared to send two divisions of heavy cruisers to Valparaiso, Chile, and two cruiser divisions and one destroyer squadron visit Callao, Peru in late May. As if to forestall the possibility of interagency disagreement, Roosevelt then forwarded Secretary Swanson's reply to Secretary of State Cordell Hull along with the somewhat loaded note asking "What do you and Sumner Welles think of this suggestion? It seems satisfactory to me. F.D.R.” ${ }^{, 76}$ In terms of total numbers of vessels and personnel, the visits that were taking shape at Roosevelt's initiative were part of the largest goodwill cruise yet undertaken in Latin American waters under the Good Neighbor: four ships of Cruiser Divisions Four and Five would visit Chile, while

\footnotetext{
${ }^{76}$ Roosevelt's initial proposal to Swanson is referenced in the Secretary's February 3, 1936 response - which FDR then sent to Secretary of State Cordell Hull with a brief cover note dated February 8, 1936. See President Franklin D. Roosevelt to Secretary of State, February 8, 1936, RG 59, File 811.3310/625, National Archives. In April, as planning for the visits progressed, an official within the State Department's Division of Foreign Service Administration noted that "The visits to Callao-Lima and Valparaiso of vessels of the United States Fleet are being made at the instance of the President." See Secretary of State to U.S. Consul in Valparaiso, Chile, April 3, 1936, RG 59, File 811.3310/651, National Archives.
} 
fourteen vessels of Cruiser Divisions Six and Seven, along with Destroyer Squadron Twenty, would visit Peru. ${ }^{77}$

Upon learning of the makeup of the naval contingent set to visit Chile, the U.S. Ambassador to that country, Hoffman Philip, expressed concern to the State Department that the visit could enflame Chilean sensitivities stemming from a violent altercation in 1891 between American sailors of the cruise U.S.S. Baltimore and locals in Valparaiso. The dispute had quickly ignited a diplomatic crisis that nearly led to war. ${ }^{78}$ But there was no stopping the planned visit, which was being made at President Roosevelt's personal insistence: the ships' visits to Valparaiso, and especially to Callao-Lima, were designed to publicly showcase the Navy as a shining messenger of good neighborism. As it had during Hoover's goodwill tour and in numerous cruises since, in both cases Washington relied on sailors to serve as de facto diplomats. The crews' agendas were packed with activities intended to show respect for the host countries' national sovereignty, and to maximize the visibility of the American ships and personnel. ${ }^{79}$ The visit to Valparaiso was the smaller and more modest of the two visits. Its focal point came when, before a large crowd of Chilean naval personnel and civilians, the two ranking U.S. officers, Thomas Hart and Harry Brinser

\footnotetext{
${ }^{77}$ Chief of Naval Operations (Acting) to Secretary of State, March 3, 1936, RG 59, File 811.3310/626, National Archives.

${ }^{78}$ The U.S. Navy's reputation in Chile had suffered considerably since the "Baltimore Affair" of 1891, and, Philip believed, it was of the utmost importance this time around that the Navy impose "the most rigorous discipline" on its sailors in order to soothe Chilean nerves that were still somewhat raw more than four decades after the Baltimore affair. See Acting Secretary of the Navy to Secretary of State, March 23, 1936, RG 59, File 811.3310/638, National Archives. For more on the Baltimore crisis, see Joyce S. Goldberg, "Consent to Ascent: The Baltimore Affair and the U.S. Rise to World Power Status," The Americas 41, no. 1 (1984): 21-35. See also Hagan, This People's Navy: The Making of American Sea Power, 198-200.

${ }^{79}$ Showcasing the technological advancement of the visiting ships does not appear to have been a major objective during these visits to Valparaiso and Callao-Lima, likely because none of the visiting ships were as highly symbolic of American ingenuity as the aircraft carrier Ranger. Rather, it is clear both from the agendas the State Department drew up for these visits and from the after-action reports that U.S. diplomats in both countries filed that the purpose was ensuring the American sailors' and ships' maximum contact and visibility with locals.
} 
(both Rear Admirals, U.S. Navy), laid a wreath at a monument to Captain Arturo Prat, a Chilean naval hero who died in battle with the Peruvian fleet during the War of the Pacific. ${ }^{80}$ By design, enlisted sailors from the four American vessels spent considerable time with the local population, touring Valparaiso and the capital, Santiago, while also participating in a recreational "field day of sports" organized by the local American expatriate community at the local Sporting Club. All four ships were open to visitors for two of their three full days in port. And one evening, at Admiral Hart's instruction, the Cruiser Divisions' combined band also staged a public concert ashore. ${ }^{81}$ Chilean press coverage of the visit was positive, but not effusively so. Santiago's largest daily, La Nacion, saw the U.S. Navy as an appropriate emissary of norteamericano good neighborism, given Chile's longstanding status as one of South America's preeminent naval powers. "A country of sailors, such as ours, which has in its history distinctive acts and deeds of extraordinary heroism," it concluded, "has always found in the American Navy Men special motives for admiration." It was a sentiment echoed by another Santiago daily, El Diario Ilustrado, which on the American ships' last full day in port commended American personnel for rendering homage to the nation's naval hero, Prat, and concluded that such displays would help "guarantee the good neighbor relations which

\footnotetext{
${ }^{80}$ U.S. Consul in Valparaiso to Secretary of State, June 5, 1936, RG 59, File 811.3310/699, National Archives. Widely regarded as a heroic figure in Chile, Prat commanded the Chilean ship Esmerelda, which was sunk by the Peruvian ship Huáscar (commanded by Peruvian naval hero Miguel Grau Seminario) at Iquique on May 21, 1879. Before his ship succumbed to the damage inflicted on it by a ramming from the Huáscar, Prat famously shouted "Board it, boys!" as the enemy ship drew close to inflict the lethal blow, and proceeded to board the Huáscar. He was killed by a Peruvian sailor's sword seconds later. For more, see Sater, Andean Tragedy: Fighting the War of the Pacific, 1879-1884, 127-30.

${ }^{81}$ Activities of American sailors in Chile summarized in a copy of U.S. Ambassador Hoffman Philip's afteraction report that was sent to the Navy Department. See U.S. Ambassador to Chile (Philip) to Secretary of State, June 3, 1936, RG 80, File FF3/A4-3, Box 2167, National Archives.
} 
President Roosevelt cultivates with such determination for the welfare of America and of the world." 82

The concurrent visit to Callao-Lima was considerably larger and more diplomatically significant for the United States because the stakes were higher in Peru than they were in Chile. Although the Depression had put a damper on trade between the two countries, the United States still carried on more extensive trade with Peru than with Chile throughout the 1930s, while American companies had invested in Peru at a far greater clip than they did in Chile. ${ }^{83}$ But, as noted earlier in this chapter, since the demise of Leguía, relations had become considerably more difficult. Anti-American sentiment ran high in Peru during the depression's early years. And since Sánchez Cerro’s April 1933 assassination, Peru had been ruled by a military man, General Oscar Benavides, with fascist leanings who held the United States at arm's length while seeking ever-closer ties with Germany and Italy. Clearly, the timing of the U.S. Navy's visit to Callao-Lima was significant. To U.S. foreign policymakers, it was important that the fourteen ships and the more than six thousand crew that arrived on May 28th perform their diplomatic roles ably and serve as emissaries of good neighborism. The Roosevelt administration, including the president himself, was counting on the Navy to score victory for its good neighbor diplomacy. ${ }^{84}$

\footnotetext{
${ }^{82}$ Press clippings contained as attachments to U.S. Ambassador to Chile (Philip) to Secretary of State, June 3, 1936, RG 80, File FF3/A4-3, Box 2167, National Archives.

${ }^{83}$ See Pike, The United States and the Andean Republics: Peru, Bolivia, and Ecuador, 236-68. For more on Roosevelt's emphasis on boosting U.S. trade with Latin America, see Schoultz, Beneath the United States: A History of U.S. Policy Toward Latin America, 303-04.

${ }^{84}$ Lawrence Clayton write that "Benavides was not a fan of the United States, its people, or its institutions. He had spent many years in Europe, especially in France and Italy, in various military and diplomatic missions, and was disposed to favor Germans and Italians equally with Americans in Peru's relations with foreigners. Fascist in political orientation, Benavides challenged the ongoing prewar U.S. effort to create a solid, democratic Western Hemisphere front." Clayton, Peru and the United States: The Condor and the Eagle, 160.
} 
During the Navy's four-day stay in Callao, American naval personnel engaged in public demonstrations of respect for Peruvian sovereignty that were larger than those the Navy conducted on any other goodwill visit to date. The "biggest single event of public interest" during the Navy's visit, the U.S. embassy reported afterward, was the parade on Saturday, May 30th of more than eleven-hundred American sailors and Marines through the streets of historic central Lima. It was a spectacle witnessed by thousands of Peruvians along the narrow, crowd-lined streets of the old city, culminating in the historic Plaza de Armas with a pass-in-review (complete with military salute) before President Benavides and his cabinet, who were assembled with U.S. dignitaries on a balcony with a commanding view high above the procession. ${ }^{85}$ The review in front of the presidential palace was the exclamation point on a several hours-long demonstration choreographed to publicly unite, in true good neighbor fashion, the American Navy men's observation of their own nation's "Decoration Day" (later known as Memorial Day) holiday with shows of respect for Peru's national history and institutions. The parade was preceded by a public ceremony at the tomb of Admiral Miguel Grau Seminario, Peru's naval hero from the War of the Pacific, with all eleven-hundred of the U.S. personnel who would later march in the parade participating (see Appendix 1, Photo 4). During the ceremony Charles Snyder (Rear Admiral, U.S. Navy), commander of Cruiser Division Six, laid an arrangement of white roses in the shape of a ship's anchor at the foot of the Grau sarcophagus and, addressing the assembled crowd, pronounced himself proud, as a sailor and as an American, to pay respects to Admiral Grau, the Peruvian Navy, and the Peruvian nation. Snyder's remarks were followed immediately by a smart salute, in unison, from the assembled ranks of American sailors and Marines, and

\footnotetext{
${ }^{85}$ Secretary of U.S. Embassy (Lima, Peru) to Secretary of State, June 3, 1936 - copy forwarded to Secretary of the Navy, RG 80, File FF3/A4-3, Box 2167, National Archives.
} 
then by remarks from the Chief of the General Staff of the Peruvian Navy, José M. Olivera. Olivera expressed the appreciation of all Peruvians for the honors their visitors had rendered. The country had welcomed periodic U.S. naval visits with "true joy" in the past, he continued, but "never until today have American sailors disembarked and presented honors in such irreproachable form to our national warriors." ${ }^{, 86}$

An ambitious schedule of sporting competitions between American and Peruvian teams complemented the formal, ceremonial displays of respect. Held "practically every day" during the American ships' visit, they were organized to be larger and more diverse than those held during other goodwill naval visits to Latin American countries (encompassing baseball, basketball, target shooting, boxing, and tennis), on the idea that displays of good sportsmanship would reinforce the visit's broader goodwill message. ${ }^{87}$ The games and matches pitted American athletes against teams composed of Peruvian naval and military men, university students, and even foreigners from Lima's vibrant international community. Unlike those held during the Navy's concurrent visit to Chile, which were held at a sporting-country club, the events were held in public venues throughout the Callao-Lima area. This public visibility ensured that the competitions were covered heavily by Lima's newspapers. The city's most influential daily, El Comercio, for one, devoted a special section of its June 1st issue to coverage of the games, and reported that high spirits prevailed throughout the competitions. It noted with satisfaction the triumph of the Peruvian pistol

\footnotetext{
${ }^{86}$ Summary of ceremony at the Grau tomb, including remarks from Rear Admirals Snyder and Olivera, contained in Lima newspaper coverage. See "Emocionado homenaje al héroe de Angamos rindieron los marinos de la División Naval Norteamerícana," La Cronica, May 31, 1936. Original text contained as attachment in U.S. Embassy dispatch summarizing the U.S. Navy visit: Secretary of U.S. Embassy (Lima, Peru) to Secretary of State, June 3, 1936 - copy forwarded to Secretary of the Navy, RG 80, File FF3/A4-3, Box 2167, National Archives.

${ }^{87}$ See Secretary of U.S. Embassy (Lima, Peru) to Secretary of State, June 3, 1936 - copy forwarded to Secretary of the Navy, RG 80, File FF3/A4-3, Box 2167, National Archives.
} 
team from the local Club Internacional Revólver Lima over "los marinos yanquis" (the Yankee sailors), a victory it called "a new and resounding success" and an "unequivocal demonstration" of the Club's (and the sport's) development in Peru. Although Peruvian baseball teams were not so fortunate against more experienced U.S. teams in several games at Lima's National Stadium, El Comercio reported, the Peruvian players played "determined" baseball in defeat. The American basketball team from the cruiser San Francisco lost a spirited contest to a team from the local Circolo Sportivo Italiano (Italian Sports Club) by a score of 44 to 28, while sailors from the Minneapolis narrowly defeated a local university team in a follow-on match before an enthusiastic crowd that erupted in generous applause for both teams. Dozens of photographs of the action were published alongside the game synopses, action shots depicting athletes in the flow of competition as well as posed shots of the American and local teams, smiling, arm in arm. They were the kind of images that might have permeated the dreams of the Good Neighbor's architects back in Washington. In total, hundreds of U.S. sailors participated, and were lauded by American and Peruvian officials for their good sportsmanship. ${ }^{88}$ From the large number of clippings embassy staff sent to Washington, it is clear that the events were intended to be far more than recreational diversions for the American sailors who took part. They were an integral part of the visit's diplomatic agenda.

The Navy's warm reception by the Peruvian public and press represented a marked change from the early post-Leguía years, and suggested to U.S. foreign policymakers an acceptance of the Roosevelt administration's efforts to turn the page on the United States'

\footnotetext{
${ }^{88}$ See "Los equipos de tiradores del Club Internacional Revólver 'Lima' No. 4, se anotaron un nuevo éxito ayer en los matchs sostenidos con los marinos norteamericanos," "Baseballistas del "New Orleans" Ganaron a la liga Chalaca," and "CCircolo Sportivo Italiano', en lucid a competencia de basket ball, venció al cuadro representativo del 'San Francisco'," El Comercio, June 1, 1936 - contained as attachments to Secretary of U.S. Embassy (Lima, Peru) to Secretary of State, June 3, 1936, RG 80, File FF3/A4-3, Box 2167, National Archives.
} 
interventionist past in Latin America. On the day the American vessels arrived, an editorial in the newspaper El Universal welcomed the "Yankee sailors" as "ambassadors of the country which is a leading representative of human progress," and concluded that old fears of American imperialism were unfounded in the face of "new tendencies of North American policy" shaped by President Franklin D. Roosevelt. La Noche echoed the sentiment, also referring to the visiting U.S. naval personnel as "Ambassadors of a nation which constitutes the exponent of human progress" and predicting that the visit would "strengthen even more the bonds which unite Peru with the powerful Republic of the North." El Comercio lauded Roosevelt's Good Neighbor Policy as "a diplomatic principle worthy of frank stimulation," and called the Navy's visit a "fruitful opportunity of Americanist cooperation" and a chance to start realizing "the wishes of the continent and solve the material and moral problems of humanity." 89 The generally positive outlook of the Lima press was quickly noticed by staff in the U.S. embassy. In a report to Washington, the embassy noted that during its stay the fleet "evoked a more cordial and friendly press comment toward the United States than has been evident here for many years." That was especially true of El Comercio, which had been at best "non-committal" toward Washington in years past, and "unfriendly" generally. During the Navy's visit, however, the paper "led all of the other newspapers" in the city in the amount of space it devoted to covering the American sailors' activities. Its pages were filled with photographs of the American sailors' activities, official and unofficial. The May 30th issue, for example, featured a collage of images depicting U.S. sailors and Marines on the streets of Lima - one of marine talking with a group of local businessmen; another of a marine and sailor politely examining a book, perhaps in response to a sales pitch delivered by

${ }^{89}$ Editorials of May 28, 1936 excerpted in Secretary of U.S. Embassy (Lima, Peru) to Secretary of State, June 3, 1936, RG 80, File FF3/A4-3, Box 2167, National Archives. 
the expectant-looking children next to them; and one of a sailor, smiling broadly, walking down a sidewalk hand in hand with a Peruvian child. ${ }^{90}$ To the delight of U.S. diplomats, the Navy's visit enjoyed such "unanimously" cordial coverage across all the city's major dailies.

One reason, it appears, that local coverage was so positive was that both press and public expected the presence of six-thousand U.S. naval personnel to be a boon to the local economy. During the four-day visit, advertisements trumpeting diversions for U.S. sailors filled the local papers. On the day the ships pulled into port, May 28th, El Comercio ran an ad (in English) for "Cock Fights - with Steel Spurs - In honour of the American Fleet," announcing seven fights "to the death" that night and the next, as well as the availability of a "bar and lunch counter on the premises." A1 Another, also in English, announced a "Maritime Bar and Cabaret" (claiming to be the "Best Place in Callao") just one block from the naval docks, complete with an in-house money exchange and English-speaking staff. ${ }^{92}$ American sailors did their part to oblige, evidently spending liberally during their stay. On the Americans' second day in port, La Prensa noted a considerable uptick in commercial activity in Callao and Lima, driven by U.S. sailors and Marines buying everything from shoes to clothing to blankets and toys, and frequenting cafes, restaurants, and engaging in "significant drinking" in local bars. ${ }^{93}$ (Interestingly, there appeared to be no major incidents of unruliness, as the embassy reported approvingly of the "excellent behavior of the men while

\footnotetext{
${ }^{90}$ Photos featured with "La visita de la División Naval Norteamericana," El Comercio, May 30, 1936 contained as attachment to Secretary of U.S. Embassy (Lima, Peru) to Secretary of State, June 3, 1936, RG 80, File FF3/A4-3, Box 2167, National Archives.

${ }^{91}$ El Comercio, May 28, 1936 - contained as attachment to Secretary of U.S. Embassy (Lima, Peru) to Secretary of State, June 3, 1936, RG 80, File FF3/A4-3, Box 2167, National Archives.

92 El Comercio, May 28, 1936 - contained as attachment to Secretary of U.S. Embassy (Lima, Peru) to Secretary of State, June 3, 1936, RG 80, File FF3/A4-3, Box 2167, National Archives.

${ }^{93}$ See "Las Tiendas de Comercio del Callao" and "Las Tiendas de Comercio de Lima," both in La Prensa, May 29, 1936 - contained as attachment to Secretary of U.S. Embassy (Lima, Peru) to Secretary of State, June 3, 1936, RG 80, File FF3/A4-3, Box 2167, National Archives.
} 
on shore" and noted that it was "highly commented upon" by Peruvian officials and newspapers throughout the Navy's stay.) And on the day the ships departed, El Universal lamented the departure of the sailors of "Tio Sam" (Uncle Sam), who had spent freely during their stay. $^{94}$

As the three divisions pulled out of Callao and headed for their home port of San Diego, California, U.S. diplomats in Lima declared their visit a resounding success. American personnel had demonstrated Washington's respect for Peruvian institutions, and had carried themselves in a manner befitting a good neighbor. The early returns seemed to indicate that the visit had "inspired conspicuous goodwill and cordiality amongst all classes of Peruvians." The largest U.S. Navy goodwill cruise to date had achieved exactly what Roosevelt intended: the Navy had demonstrated, in a highly public way, the good neighbor bonafides of the United States. And importantly, that victory had been scored in Peru, where relations had been difficult for a number of years.

The success of the 1936 goodwill visit to Peru was important for several reasons in the years that immediately followed. First, it further validated naval cruising as an instrument of good neighbor diplomacy, and set the stage for the Navy to undertake an even more ambitious schedule of goodwill visits throughout Latin America. In 1937, 1938, and 1939, by mutual agreement the State Department and the Navy dispatched even more cruises to Latin American countries for the purposes of generating goodwill. Second, it gave the Roosevelt administration a considerable boost in its efforts to rebuild U.S. influence in Peru, which had been in tatters since the end of Leguía's Oncenio. And third, it underscored that

\footnotetext{
94 “O.K. 'Uncle Sam' Sailors,” El Universal, June 2, 1936 - contained as attachment to Secretary of U.S. Embassy (Lima, Peru) to Secretary of State, June 3, 1936, RG 80, File FF3/A4-3, Box 2167, National Archives.
} 
while conveying messages of good neighborliness, American naval ships could also clearly communicate the strength of the United States.

This last factor grew in importance as Roosevelt administration became increasingly concerned throughout 1936 about German and Italian aggression in Europe and the possibility that another devastating war could engulf the European continent. In 1935, Benito Mussolini's Italy had invaded the East African nation of Ethiopia in an attempt to establish a new Italian empire. In March 1936 German Chancellor Adolf Hitler had ordered his powerful army, the Wehrmacht, to occupy the Rhineland, a demilitarized zone on the German-French frontier that had been established in 1919 by the Treaty of Versailles. ${ }^{95}$ Fearing that war in Europe would invariably threaten the Western Hemisphere, in early 1936 Roosevelt pressed the other nations of the Americas to gather in the near future "to determine how the maintenance of peace among the American Republics may best be safeguarded" amid the growing danger. ${ }^{96}$ Out of that initiative came the Inter-American Conference for the Maintenance of Peace, which convened in Buenos Aires in December of 1936.

Determined to forge an inter-American consensus to confront the growing threat, Roosevelt decided to lead the U.S. delegation to the conference himself. Making the twelve-thousand mile roundtrip journey aboard the cruiser U.S.S. Indianapolis, along the way he used stops in Rio de Janeiro and Montevideo to conduct some goodwill naval diplomacy of his own. As Robert Dallek notes, in Rio "huge throngs gathered" to greet Roosevelt at the city's pier,

\footnotetext{
${ }^{95}$ Historian P.M.H. Bell notes that before Hitler's order of March 7, 1936 to occupy the Rhineland, it had been "the fixed intention of all German governments" since the First World War to "do away with the demilitarized zone when it became possible to do so, partly because it was an affront to German sovereignty and self-respect, and partly because it left the Rhineland exposed to attack." For more on Hitler's decision, as well as Mussolini's move to invade Ethiopia, see P. M. H. Bell, The Origins of the Second World War in Europe, Origins of Modern Wars (London; New York: Longman, 1986), 228-33.

${ }^{96}$ Quoted in Dallek, Franklin D. Roosevelt and American Foreign Policy, 1932-1945: With a New Afterword, 122.
} 
shouting "Viva la democracia! Viva Roosevelt!" And in Buenos Aires, crowds estimated at more than two million people "packed in every conceivable point of vantage" greeted Roosevelt "with wild acclaim and showered him with flowers as he passed." ${ }^{97}$ By now accustomed to seeing naval ships as emissaries of U.S. good neighborism, Latin Americans for the first time since Hoover's goodwill tour saw an American president personally engaged in good neighbor diplomacy on their soil. That Roosevelt, ever the naval man, was doing it from the deck of a modern cruiser only seemed natural. Moreover, his efforts at Buenos Aires bore fruit: as he had hoped at the outset, delegates to the conference agreed to consult one another should a clear threat to peace emerge in the Western Hemisphere. ${ }^{98}$

\section{GROWING CONCERNS OVER HEMISPHERIC SECURITY}

With a guarantee of some measure of inter-American cooperation in the event of extra-hemispheric aggression, the Roosevelt administration turned its attention in the late 1930s to combating what it saw as the growing influence of Germany and Italy in Latin America. ${ }^{99}$ Not surprisingly, heightened concern about European encroachment in Latin America drove another clear shift in the tenor of the goodwill naval diplomacy Washington practiced there. Although public displays of U.S. respect for Latin American sovereignty remained important, they were increasingly complemented by efforts to publicly showcase the strength and technological prowess of the United States. In the late 1930s the emerging goal of American naval visits to Latin American ports was to send the clear message that not

\footnotetext{
${ }^{97}$ Ibid., 132-33.

${ }^{98}$ At the conference, the U.S. delegation faced determined opposition from Argentine Foreign Minister Carlos Saavedra Lamas, who argued against establishing a permanent committee to conduct inter-American consultations when the need arose. Ibid., 134.

${ }^{99}$ Dozer, Are We Good Neighbors?, 38-54.
} 
only was the United States a good neighbor, but was capable of leading an effective defense of the hemisphere. This transformation is most clearly visible in U.S. participation in the Inter-American Technical Aviation Conference held in Lima in September 1937. Convened with the goal of promoting and standardizing commercial aviation as a means of expanding commercial and communications exchanges among nations of the Americas, the Conference was an outgrowth of aviation discussions that had been held on the periphery of earlier interAmerican conferences. ${ }^{100}$ As an active participant in past inter-American conferences and as a key player in the development of commercial aviation in South America (most notably in Peru during the 1920s), the United States quite naturally wanted a clear voice in deliberations over future inter-American aviation links.

But the issue took on new urgency when word began to filter through Washington that, at the invitation of the Peruvian government, Italy would be sending a large delegation to participate in the conference as well. That the Italians would be the only participants from outside the Americas gave Washington pause. As early as April 1936 the State Department had expressed concern about the "disadvantage" that U.S. aviation interests (manufacturers of planes and equipment as well as builders of landing fields and airport facilities) would face should Latin American nations standardize their commercial aviation establishments along European lines. ${ }^{101}$ Those fears were only amplified by the word filtering into

\footnotetext{
${ }^{100}$ Resolution LIII of the Seventh International Conference of American States (held at Montevideo, Uruguay in December, 1933) called on participating nations to study "within the shortest possible time...the means of still further accelerating Inter-American aviation, by the establishment of a continuous line of Radio Stations, Beacons and Aerodromes, along the line of existing routes and others that may be considered desirable, and to determine what additional methods may be devised to bring about more rapid inter-American aerial communication facilities." That call was reiterated in Resolution XXXVIII of the Pan-American Commercial Conference held at Buenos Aires, Argentina in June, 1935, and again in Resolution XLVIII of the InterAmerican Conference on the Maintenance of Peace (also held in Buenos Aires) in December, 1936. Resolutions filed in RG 80, File A19(5)/EM-Lima, Box 787, National Archives.

${ }^{101}$ Memorandum of Telephone Conversation Between Navy and State Department, April 28, 1936, RG 80, File A19(5)/EM-Lima, Box 787, National Archives.
} 
Washington in early 1937 that the Peruvian President Oscar Benavides (who had studied in European military schools earlier in his career, and whose fondness for Italian-style fascism was well-known) was considering asking the Mussolini government for an Italian aviation mission, as well as a group of mining experts from Italy to help develop his nation's iron reserves. Such experts, Benavides was reported to have told Rome, would release Peru from its "mining vassalage to the United States." "102 It was part and parcel of the growing volume of intelligence flowing into Washington in 1937 that seemed to confirm that European powers were increasingly intent on expanding their strategic and commercial influence in the Americas.

Italy's participation in the conference set the stage for a public diplomacy showdown, as the Italian delegation planned a series of high-profile public events during the proceedings aimed at expanding the appeal of Italian aviation in Latin America. In late May 1937, little more than three months before the conference was to begin in Lima, the U.S. naval attaché there relayed word to Washington that during the conference the Italian government would present the host nation with a monument to Peruvian aviation pioneer Jorge Chávez, who had died in Italy in 1910 in an attempt to become the first aviator to traverse the Alps. The unveiling of the monument on Peru's national dia de aviación (aviation day) would be one of the conference's main events, one celebrated by aerial demonstrations put on by flyers invited from all participant nations. Along with the monument, the report noted, Italy planned to send "a mass flight of military planes" to Lima to participate in the unveiling ceremony. To offset the effects of that public demonstration of Italy's aviation prowess, the attaché concluded, it was "highly essential" that the United States send "as large a group of

\footnotetext{
${ }^{102}$ Memorandum to Under Secretary of State Sumner Welles, November 11, 1937, RG 59, Entry 209, Box 59.
} 
planes" as possible to make an aerial demonstration during the conference as well. ${ }^{103}$ When a formal invitation to send a delegation of planes arrived from the Peruvian government, Under Secretary of State Sumner Welles, the Roosevelt administration's point man on Latin America and a believer in the efficacy of naval power for goodwill purposes, agreed. In early June he wrote to Navy Secretary Claude Swanson that "as a matter of policy" it would be "highly desirable" to not only send American aircraft to participate in the unveiling ceremony, but aircraft "of the latest type." Sensing the opportunity to gain an upper hand in the public eye over the Italian contingent, Welles further recommended that a modern aircraft carrier be sent to Lima "to cooperate with the planes" and to serve as a visible indication of American naval prowess. ${ }^{104}$ Navy officials concurred, designating the U.S.S. Ranger - the darling of the State Department since its 1934 shakedown cruise to South America - for the job. "The presence of aviation representatives of many South American countries" at the conference, Ernest J. King (Admiral, Commander of Aircraft, Base Force, U.S. Fleet) noted in agreement, "appears to present an excellent opportunity to advance the prestige of American Aviation and promote general goodwill and friendliness toward our South American neighbors."

By the time the Ranger arrived in Callao on September 15, 1937, the conference had developed into the competition for influence that U.S. diplomats had expected. The Ranger's commander, John S. McCain (Captain, U.S. Navy), called it "a contest for supremacy [in South America] between American methods and equipment, and European, of which those of

\footnotetext{
${ }^{103}$ Report of the U.S. Naval Attaché to Peru, May 29, 1937, "Peru - Pan American Aeronautical Conference," RG 80, File A19(5)/EM-Lima, Box 787, National Archives.

${ }^{104}$ Under Secretary of State to Secretary of the Navy, June 8, 1937, RG 80, File A19(5)/EM-Lima, Box 787, National Archives.

${ }^{105}$ Commander of Aircraft, Base Force, U.S. Fleet to Chief of Naval Operations, August 11, 1937, RG 80, File A19(5)/EM-Lima, Box 787, National Archives.
} 
Italy were strongly supported." But upon arriving in Lima, American officials discovered that the detachment of Italian aircraft at the conference totaled only twelve stunt planes, a far cry from the "mass flight" of planes that prior intelligence had anticipated. ${ }^{106}$ But the Ranger arrived ready for a public diplomacy showdown on a grand scale nonetheless, with a full complement of seventy-eight planes: eighteen bombers, eighteen fighters, thirty-seven scouting aircraft, and five utility planes. ${ }^{107}$ Wasting no time, McCain ordered the Ranger's planes to make their first demonstration flights almost immediately, on September 17th, six days before the larger exhibition that would accompany the unveiling of the Chavez monument. Flying at low altitude due to "mediocre" weather conditions, sixty-six of the Ranger's seventy-eight planes carried out a practice flight in which four large open formations passed over the Limatambo airfield (in the San Isidro section of Lima) before dividing into what the influential Lima newspaper El Comercio called "eight large and perfect" V-shaped formations, which then "paraded in magnificent form" back over the airfield before returning to the Ranger. It was a "brilliant demonstration of capacity, power, efficiency, and safety," El Comercio reported, an impressive spectacle attended by "a large number of people" who "applauded the North American pilots' precision enthusiastically from start to finish."108 As the paper noted, this warm-up performance was far more

\footnotetext{
${ }^{106}$ Commanding Officer, U.S.S. Ranger to Chief of Naval Operations, "Report of Visit of U.S.S. Ranger to Callao, Peru, in connection with the Inter-American Technical Aviation Conference," RG 80, File A19(5)/EMLima, Box 787, National Archives.

${ }^{107}$ Confirmation that the Ranger would arrive in Lima with a full complement of 78 naval aircraft is contained in Secretary of State to the Members of the American Delegation to the Inter-American Technical Aviation Conference, September 2, 1937, in Foreign Relations of the United States, 1937, Vol. V (Washington, DC: U.S. Government Printing Office), 199. Specific information on the types of aircraft sent is included in Acting Secretary of the Navy to Secretary of State, August 7, 1937, RG 59, File 579.6 AC 1/168, National Archives.

108 “Aviones de la Armada de Estados Unidos de Norteamérica ofrecieron ayer una brillante exhibición,” El Comercio, September 18, 1937 - contained in RG 59, File 579.6 AC, National Archives.
} 
successful than the first sortie of the smaller-than-expected twelve-plane Italian contingent, in which two of its craft "cracked up in a cross-wind" before they could make it into the air.

On the day the Italian delegation unveiled and dedicated the Jorge Chávez monument, as Welles had hoped, the Ranger's planes stole the show. As the largest and most heavily publicized contingent participating in the event, the American aircraft were the first to parade overhead following the formal speeches of the dedication ceremony. El Comercio reported that, flying in four "perfectly formed" formations as they had days earlier, the American planes "offered a unique and impressive spectacle" to the thousands of spectators assembled near the new Chavez monument. Flying from the Ranger's position in the waters just off Callao, the planes proceeded in a north-to-southeasterly direction, passing directly over top of the dignitaries assembled near the monument and, upon completing their initial pass, executed a broad left turn along Lima's seacoast before dividing (as they had on the 17th) into eight "large and perfect" V-shaped formations. In tight new formations they passed a second time over the assembled crowd "in magnificent form," the paper noted, with the apex of each formation pointed forward and with the aircraft arrayed so tightly that, to some observers on the ground, it "appeared as if the wings were touching." The precision with which American pilots carried out their maneuvers sent the clear visual message that the U.S. State Department no doubt intended: in the realm of aviation, the United States was a world leader. Amplifying that message quite literally was the sound of the demonstration. "The engine noise of the American planes was powerful and isochronous," El Comercio noted, and "enveloped the field with a deafening noise" that reflected the "strength and number of 
planes involved." 109 It was precisely the kind of display that Sumner Welles and the State Department had envisioned: outnumbering those of every other nation in attendance, American planes assumed a central, high-profile place in the festivities, were warmly received by the locals, and garnered favorable coverage in the local press.

To U.S. foreign policymakers, the Ranger's visit was a resounding success. It had been a rousing demonstration of the capabilities of American aviation, Captain McCain concluded while sailing back to California. The flights had given U.S. goodwill cruising, which up to that time had centered around ships and sailors, a dynamic new dimension. Echoing the local reporting by El Comercio, McCain noted that the "mass flights" launched from the Ranger's flight deck had been "cheered enthusiastically by the populace," and that “the disciplined precision of the Squadrons' maneuvers" had been "complemented highly" by officers of the other military establishments in attendance. The chief of the U.S. delegation to the conference, Dr. Harry Block, expressed his approval as well, noting that the Ranger's presence and the displays put on by its airplanes had "measurably strengthened" the American position in the conference deliberations and "materially furthered" the cause of U.S. civil aviation throughout South America. ${ }^{110}$ U.S. Ambassador to Peru Laurence Steinhardt agreed, reporting to the State Department in Washington that the "coordination, perfect discipline and fine formations evoked the loudest praise among Peruvian Government officials" as well as the gathered public. ${ }^{111}$ The most satisfying assessment of the visit's

\footnotetext{
109 "La inauguracion del monumento a Jorge Chavez: el homenaje al heroe revistio gran solemnidad - hermoso espectaculo ofrecido por las escuadrillas nacionales y extranjeras," El Comercio, September 24, 1937 contained in RG 59, File 579.6 AC, National Archives.

${ }^{110}$ Commanding Officer, U.S.S. Ranger (McCain) to Chief of Naval Operations, "Visit of the U.S.S. Ranger to Callao, Peru, in connection with the Inter-American Technical Aviation Conference," October 4, 1937, RG 80, File A19(5)/EM-Lima, Box 787, National Archives.

${ }^{111}$ U.S. Ambassador to Peru to Secretary of State, September 27, 1937, RG 59, File 811.3310/974, National Archives.
} 
effectiveness, however, came from President Benavides himself, who had lunched aboard the Ranger during its visit and who, in the days after the ship's departure, wrote to Roosevelt expressing gratitude "for the cordial attitude of the good neighbor, with which the Navy and Aviation corps of the United States of America have associated themselves in glorifying the Peruvian Aviator, Jorge Chavez."112

Proof of the demonstration's effectiveness, however, came only after the initial exchange of niceties. In the weeks that followed, the Peruvian Government began to signal a growing sensitivity to the Roosevelt administration's concerns about Italian influence in Peru. On November 22, the Peruvian Ambassador in Washington, Manuel de Freyre y Santander, wrote to Secretary of State Cordell Hull conveying his government's special thanks for the participation of U.S. planes in the dedication of the Chavez monument, and announcing that President Benavides had awarded La Orden El Sol del Peru (the Order of the Sun), the highest award the nation could bestow, on Dr. Block, Captain McCain, and the commanders of the two naval vessels that had accompanied the Ranger to Peru. Employing the language of hemispheric solidarity that was coming increasingly into vogue with a Roosevelt administration concerned about European threats to Latin America, Freyre wrote that the actions of these men, and of the American pilots who participated in the unveiling, were evidence of "a solid continental unity" and of "a true American solidarity" that existed among the nations of the Americas. ${ }^{113}$ It was the first time that the Benavides government spoke in such terms.

\footnotetext{
${ }^{112}$ President of Peru to President of the United States, September 28, 1937, RG 59, File 579.6 AC 1/255, National Archives.

${ }^{113}$ Peruvian Ambassador to the United States to Secretary of State, November 22, 1937, RG 59, File 579.6 AC 1/294, National Archives.
} 
Yet the success of the Ranger's aerial public diplomacy did not extinguish Washington's fears of growing European encroachment in Peru and throughout Latin America. Rather, the United States emerged from the Inter-American Technical Aviation Conference with a heightened sense of concern about Italian and German ambitions in South America. Although the performance of the Italian aviation contingent had been marred mechanical failures, U.S. Ambassador Laurence Steinhardt reported to Washington that the Italian representatives to the conference itself "attempted - and were partly successful - in dominating the whole picture" of the gathering. From the opening to the closing day of the conference, he noted, the Italian delegation had held high-profile events (in addition to the dedication of the Chavez monument) that were intended to highlight the Italy's and Peru's shared interests in aviation, including an exhibition of works by the designer of the Chavez monument at a local Italian-owned gallery in Lima, a wreath-laying ceremony commemorating Peruvian aviators lost in service, a gala honoring President Benavides held at Lima's country club, and a private dinner for the president and his wife held at the Italian legation - the last being an event to which "no foreign diplomats or representatives of any of the visiting delegations were invited." 114 Acts of public diplomacy in their own right, these events were well-covered by the Lima press. At the gala, for example, El Comercio reported that the country club's main hall was elegantly decorated with gold ornamentation and a host of Peruvian and Italian flags, and that, upon Benavides' arrival, a band played the Peruvian and Italian national anthems, along with the fascist hymn Giovinezza favored by Italian leader Benito Mussolini. ${ }^{115}$

\footnotetext{
${ }^{114}$ U.S. Ambassador to Peru to Secretary of State, September 27, 1927, RG 59, File 811.3310/974, National Archives.

115 "El baile de anoche en el country club," El Comercio, September 22, 1937 - contained in RG 59, File 579.6 AC, National Archives.
} 
All signs pointed, Steinhardt warned, to the possible establishment of an Italian aviation mission in Peru - a development that, if it came to pass, could open the door for the creation of Italian naval and military missions in Peru as well. The Benavides government had "unquestionably been much impressed" by the Italian public relations offensive during the recent conference, he cautioned. Because of this, the time was right to consider sending another U.S. naval mission to Peru. ${ }^{116}$ The Peruvian Navy had made a number of overtures about a new U.S. naval mission in the years since the old mission's withdrawal. With memories of the complications that had attended that earlier naval mission still fresh in its collective mind, Washington had rebuffed each attempt. ${ }^{117}$ Steinhardt argued that the time had come for the United States to reconsider. A majority of the mid-level officers on duty in the Peruvian Navy in the later 1930s had been trained during the previous U.S. naval mission's tenure, Steinhardt noted, and regretted its departure. This meant that Peruvian Navy's favorable disposition toward the United States presented Washington with an opportunity to arrest the expansion of Italian influence in Peru. ${ }^{118}$ The "net result" of the Ranger's visit during the aviation conference, he stressed, had been to make the Peruvian government even more determined to secure a new naval mission from the United States. However, he cautioned, Peruvian enthusiasm for a U.S. naval mission was not inexhaustible.

116 "The net result of the RANGER's visit to Peruvian waters," Ambassador Steinhardt wrote to Secretary of State Cordell Hull, "has been to make certain important officials of the Government more determined than ever to close contracts for the employment of American naval officers to train their navy." See U.S. Ambassador to Peru to Secretary of State, September 27, 1927, RG 59, File 811.3310/974, National Archives.

${ }^{117}$ A February, 1935 telegram from Ambassador Fred M. Dearing to Secretary of State Cordell Hull noted that the Peruvian government "greatly desires" a U.S. naval mission, and suggests that the U.S. modify its "recent disinclination" to grant such a mission. Hull denied the request, and the U.S. continued to do so until 1937 . See U.S. Ambassador to Peru to Secretary of State, February 7, 1937, RG 59, File 823.30/201, National Archives and Secretary of State to U.S. Ambassador to Peru, February 9, 1937, RG 59, File 823.30/201, National Archives.

${ }^{118}$ Months earlier, Steinhardt's predecessor, Fred M. Dearing, had reported to Washington that Peruvian naval officers had broached the subject of a new U.S. naval mission during the March, 1937 visit of the destroyer U.S.S. Cummings to Peruvian waters, and urged favorable consideration of any forthcoming request. See U.S. Ambassador to Peru to Secretary of State, March 10, 1937, RG 59, File 823.30/210, National Archives. 
Any "unreasonable delay" in reciprocating the Peruvian Navy's interest in a new U.S.

mission now could well "result in the Italians making such favorable proposals as to induce the Peruvian Government to turn over to them" the Navy as well as its aviation establishment. ${ }^{119}$ Time was of the essence.

\section{CONCLUSION}

The 1930s was a transformational decade in U.S. policy toward Latin American nations, and in U.S. relations with Peru. Beginning under Herbert Hoover and gaining momentum under Franklin D. Roosevelt, it was a time when a "good neighborism" founded on non-interference and cooperation eclipsed armed intervention as the basis for relations. U.S. credibility and prestige in the Hemisphere began to rebound after reaching an all-time low in the late 1920s and early 1930s. Central to that process was Washington's recognition that its policy had to shift from its emphasis on trying to impose order in Latin America, an approach that bred intense resentment, to a more hands-off approach aimed at fostering or cultivating order. To cultivate order effectively and bury the interventionist past once and for all, U.S. foreign policymakers recognized, Washington would have to systematically demonstrate conciliation - and in a highly public, highly visible manner. Popular attitudes would be the focus. From Herbert Hoover's pre-inaugural goodwill tour onward, the United States Navy proved indispensible in this pursuit. Time and time again, American naval vessels and personnel served as emissaries of good neighborism, communicating U.S. respect for Latin American nations' sovereignty and institutions, discharging the duties of uniformed “diplomats," and showcasing American technological progress. Those contributions would

\footnotetext{
${ }^{119}$ U.S. Ambassador to Peru to Secretary of State, September 27, 1927, RG 59, File 811.3310/974, National Archives.
} 
become all the more important as the objectives of U.S. policy changed yet again in the late 1930s, and focused on securing the Western Hemisphere from external threat. Just as it had helped prove the nation's bonafides as a good neighbor, the Navy would again prove pivotal as U.S. foreign policy sought to reassure Latin American nations that it would be a good ally, as well. 


\section{CHAPTER 5: NAVAL DIPLOMACY IN HEMISPHERIC DEFENSE, 1937-1942}

By the late 1930s, as the threat of war in Europe and the Pacific grew, United States relations with the nations of Latin America became dominated by concerns over hemispheric security. Long preoccupied with European commercial and strategic influence in the hemisphere, American officials during these years grew especially worried that the growing military might of Nazi Germany might embolden that nation's leader, Adolf Hitler, to make aggressive moves in the Western Hemisphere. In particular, they feared possible threats to the strategically vital Panama Canal and possible subversion of Central and South American governments. President Franklin D. Roosevelt had sounded the warning bell as early as December 1936, when he led the U.S. delegation to the Inter-American Conference for the Maintenance of Peace in Buenos Aires, Argentina. U.S. concerns grew steadily through 1937 and 1938, and intensified further in 1939, when European efforts to appease Hitler collapsed and Germany resorted to open warfare to achieve its expansionist goals. As the full force of the Nazi threat to Europe came into focus, intelligence flowing into Washington seemed to confirm Roosevelt's fears of Nazi aggression in Latin America.

The Roosevelt administration responded by accelerating its efforts to unify the hemisphere and bring Latin America firmly under the umbrella of Washington's strategic reach. Key to these efforts was convincing Latin American nations that the United States was capable of leading an effective defense against extra-hemispheric threats. As it had earlier, naval power played a central role in this new incarnation of good neighbor diplomacy. After having backed away from utilizing naval missions earlier in the decade, in the late 1930s the United States again began dispatching teams of naval advisers for the 
stated purpose of helping Latin American governments build the capacity to both defend themselves and contribute to an effective hemispheric defense. Although in 1937-1938 there was some division within the U.S. government as to what the exact relationship between the U.S. advisors and their Latin American counterparts should be, as American officials' fears of outside threats to the security of the Western Hemisphere grew, a consensus emerged that the U.S. had to send such missions. At the same time that such missions sought to strengthen Latin American defense establishments from within, Washington continued to send naval vessels on cruises and port visits throughout Latin America to publicly demonstrate U.S. strength and resolve to defend the hemisphere. These two threads of U.S. naval diplomacy, conceived to meet different needs at different times, became braided during the years of World War II. Both were integral components of a single, intensive U.S. effort to build and maintain inter-American solidarity in the face of a global war that, at several points, seemed poised to engulf the Western Hemisphere.

\section{REESTABLISHING THE U.S. NAVAL MISSION TO PERU}

Peru would prove to be a fertile test-bed for the new, more urgent good neighbor naval diplomacy the United States practiced in the late 1930s and early 1940s. First, Peruvians had a long history with U.S. naval advising, having been the first recipients of a U.S. naval mission following the First World War. Many of the Peruvian Navy's mid- and junior-level officers, who had come of age under the tutelage of U.S. officers during the 1920s, lamented the fact that it had been withdrawn. They lobbied through the mid-1930s for its reestablishment. Moreover, Peru had played host to a number of American naval visits in the 1930s that had emphasized the importance of naval ties, convincing U.S. policymakers that continued engagement in the naval realm would pay diplomatic dividends. 
Add to that the fact that by the late 1930s Peru was beginning to occupy an important place in emerging U.S. designs for hemispheric defense, and its importance to American naval diplomacy begins to come more clearly into focus. Geographically, Peru was not as vital a U.S. ally as Colombia, whose shores guarded both the northern and southern flanks of the Panama Canal, or Brazil, whose protrusion into the South Atlantic represented the easternmost point in the Americas. But Peru's geographic proximity to the Canal's southern end made its cooperation essential in U.S. eyes, as did its significant populations of Germans, Japanese, and Italians, as well as its large stores of militarily useful raw materials such as rubber, vanadium, copper, and oil. ${ }^{1}$ Finally, in the late 1930s, Peru was beginning to prove itself a willing U.S. partner. The United states had enjoyed a closer, more cooperative relationship with Peru throughout the first three and a half decades of the twentieth century than it had with many other Latin American nations, and the record of meaningful naval cooperation between the two was longer than the United States enjoyed with any other Latin American nation. Although tensions had run high between Washington and Lima for a time in the early 1930s following the overthrow of former Peruvian President Augusto Leguía, the relationship improved by the decade's closing years.

When Peruvian officials stepped up efforts in 1937 to obtain a new U.S. naval mission "to ensure the progressive development of the Peruvian Navy," though, American officials at first responded cautiously. ${ }^{2}$ Willard Beaulac of the State Department's Division

\footnotetext{
${ }^{1}$ Daniel Masterson notes that Peru "was considered of major importance" by U.S. policymakers in the late 1930s "because of its proximity to the approaches to the [Panama] canal and its relatively significant numbers of Japanese, German, and Italian aliens." See Masterson, The History of Peru, 132. For more on Peru's wartime exports of critical raw materials to the United States, see Clayton, Peru and the United States: The Condor and the Eagle, 161.

${ }^{2}$ Peruvian Ambassador to the United States to Department of State, September 3, 1937, RG 38, Entry 48-A, Box 4, National Archives. Driven mainly by the Peruvian Navy, which maintained a pro-U.S. attitude through the political turmoil of the early 1930s, the Peruvian government had made a number of inquiries of the U.S. State Department through about obtaining a new U.S. naval mission prior to the formal request made in late
} 
of Latin American Affairs expressed concern that another mission could get dangerously entangled in Peru's domestic affairs, and could replay the unfortunate saga of Commander Harold Grow, whose intimate association with President Leguía while a member of the U.S. naval mission to Peru had given Washington headaches in the late 1920s. Citing the "Grow case" as evidence, Beaulac advised, the United States "should defer action in the matter [of a new naval mission] as long as possible" while offering "no encouragement" on the Peruvian government's request. "From a policy standpoint," another official argued, the United States should send a naval mission to Peru only if "another country would do so in case we did not." It would be better, he agreed, for the United States not to involve itself again too deeply in Peru's sovereign affairs. By holding out on a naval mission, the United States could not only avoid possibly replaying the embarrassing Grow saga, but could avoid becoming too closely identified with "what may be an ambitious naval program of the Peruvian Government" - just as it had when naval mission chief Clark Woodward proposed a large expansion of the Peruvian fleet in the early 1920s. ${ }^{3}$

However, such voices of caution were in the minority. The main debate within the State and Navy Departments in late 1937 and early 1938 was not whether the United States should send a mission. Given the interest Italy had demonstrated in Peru's aviation and naval

1937. For example, see U.S. Ambassador to Peru to Secretary of State, February 7, 1935, RG 59, File 823.30/201, National Archives.

${ }^{3}$ State Department Division of Latin-American Affairs Memorandum to Laurence Duggan, July 22, 1937, RG 59, File 823.30/212, National Archives. Also providing insight into the State Department's reluctance to approve a new naval mission to Peru was an October, 1937 memorandum on "The Armaments Situation in the Other American Republics." It notes that the Grow situation had caused "considerable embarrassment" for the United States, and cited the episode as a reason the Department "has been reluctant to look favorably upon the informal suggestions made from time to time that the Peruvian Government would welcome another naval mission from the United States." See "The Armaments Situation in the Other American Republics," October 13, 1937, RG 59, File 810.20/53A, National Archives. 
establishments, most officials in both departments agreed, that was a settled issue. ${ }^{4}$ At the time, the State Department's Latin America hands were recommending increased naval assistance to Latin American nations across the board, a move they believed would strengthen relations, generate further goodwill, and, in "times of emergency," permit those nations to lend meaningful assistance to the United States in defense of the Americas. ${ }^{5}$ Rather, the debate revolved around how a new naval mission should operate once it was in place. The central question quickly became whether U.S. officers should exercise full command of the Peruvian naval establishment, as they had in the 1920s, or whether they should act in a strictly advisory capacity. The Peruvian officials most keenly in favor of reestablishing the mission, including Roque A. Saldías (Captain, Peruvian Navy), a senior naval officer who had worked closely with the Americans during the Leguía years, wanted officers of the mission to have "full executive authority" just as they had before. ${ }^{6}$ By the time Peru's formal request made it to Washington, President Oscar Benavides had been convinced of the merits of such an arrangement, too, and had weighed in in favor of a mission with full command authority. ${ }^{7}$ Although they agreed on the wisdom of sending another naval mission to Peru, the consensus in both the State Department and Navy

\footnotetext{
${ }^{4}$ In a July 2, 1937 letter to the Director of Naval Intelligence, the U.S. Naval Attaché in Peru, Frank Loftin (Commander, U.S. Navy), reported that, before leaving Washington for his posting in Peru, Under Secretary of State Sumner Welles had informed him that "the State Department would be heartily in favor of renewing the Naval Mission in Peru." U.S. Naval Attaché, Lima, Peru to Director of Naval Intelligence, July 2, 1937, RG 38, Entry 48-A, Box 4, National Archives.

${ }^{5}$ Division of the American Republics Memorandum, March 21, 1938, RG 59, File 810.20/62, National Archives.

${ }^{6}$ At the time, Saldías was serving as Minister of Health in the Benavides government, but retained his rank and active status in the Peruvian Navy. The U.S. State Department had been informed that Saldías was very likely to be named Minister of Marine in the very near future, a prospect that gave his lobbying for a U.S. naval mission a high degree of credibility. U.S. Naval Attaché, Lima, Peru to Director of Naval Intelligence, July 2, 1937, RG 38, Entry 48-A, Box 4, National Archives.

${ }^{7}$ U.S. Naval Attaché, Lima, Peru to Director of Naval Intelligence, July 9, 1937, RG 38, Entry 48-A, Box 4, National Archives.
} 
Department was that, in part because of past experience, U.S. personnel should not again assume command of Peru's naval establishment. In fact, Director of Naval Intelligence R.S. Holmes (Rear Admiral, U.S. Navy) informed the U.S. Naval Attaché in Lima, Frank Loftin (Commander, U.S. Navy), by then it had been "definitely established as policy not to send any more Naval Missions abroad in an executive capacity."

It was more than memories of the Grow and Woodward incidents that weighed on U.S. officials. As Holmes noted to Loftin in his detailed explanation of U.S. policy on the matter, allowing a U.S. mission to exercise command over a foreign navy would be "unwise from the point of view of American continental solidarity" as well. Getting involved in the "actual command" of the military forces of any one Latin American country was bound to "arouse hostility" toward the United States in other countries "that might feel a rivalry toward any one of the countries to which our missions were attached." Moreover, he stressed, by allowing American officers to assume rank in and take command of a foreign navy, the United States would run the risk of aligning itself too closely with particular political factions within those countries. The previous U.S. naval mission to Peru had run into problems on both counts. Now, Holmes intimated, given the potential of European subversion in Latin America, the stakes were higher than they had been in the 1920s. In the interests of hemispheric security the United States could not run the risk of fanning any regional tensions and having them flare up into armed conflict. As long as a credible European threat to the Western Hemisphere existed, no risk to inter-American unity could be tolerated. Beyond such diplomatic considerations, he further stressed, there was the simple question of whether allowing U.S. officers to have command authority was the best

\footnotetext{
${ }^{8}$ Director of Naval Intelligence to U.S. Naval Attaché, Lima, Peru, September 14, 1937, RG 38, Entry 48-A, Box 4, National Archives.
} 
prescription for the countries receiving assistance. A naval mission operating in an executive capacity would no doubt bring its host navy to "a high state of efficiency more rapidly than one operating in an advisory capacity," Holmes explained. But whether such a mission could effect lasting change was another issue. The best solution appeared to be a strictly advisory naval mission for Peru, he argued, because more permanent results could be obtained only if the mission focused its efforts on developing Peruvian officers proficient in the exercise of command and technical functions. "If the Peruvians desire to learn to be competent naval officers," Holmes stressed, "they will cooperate fully with our naval advisors" by accepting their instruction and implementing their recommendations. If, however, they were “congenitally unable to cooperate," even a grant of executive powers to the mission could not improve matters permanently. ${ }^{9}$

With regard to Peru, Washington's desire to keep regional tensions under wraps was more than theoretical. Of the many border disputes Peru had confronted during the Leguía years, only the one with Chile, which stemmed from the War of the Pacific, had been resolved peacefully. The dispute with Colombia over the Amazon River port of Leticia had escalated into a brief armed conflict, the result of which was a tactical defeat for Peru. ${ }^{10}$ The border that remained an open question in the late 1930s was the northern one Peru shared with Ecuador, a frontier the two countries had disputed almost since independence on account of the inexact colonial boundaries drawn by Spanish authorities. The first concerted efforts to resolve the situation occurred in the 1880s and culminated in the García-Herrera Treaty of 1890, an agreement the Peruvian Congress failed to ratify out of a belief that the arrangement denied Peru all the land it was due under the old colonial demarcations. The

\footnotetext{
${ }^{9}$ Ibid.

${ }^{10}$ Masterson, The History of Peru, 135-36.
} 
situation remained unresolved for decades, into the late 1930s, despite numerous mediation attempts by Brazil, Argentina, Spain, and eventually the United States. Throughout this lengthy period of limbo, Peruvian and Ecuadorian military units skirmished occasionally along the disputed frontier. Out of frustration with the lack of progress on a permanent settlement, the Peruvian delegation would pull out of U.S.-brokered negotiations in Washington in September 1938, accelerating the longstanding tensions even further. ${ }^{11}$ It was in part out of a desire to save these ultimately ill-fated negotiations and achieve a peaceful settlement that the United States had been reluctant to grant Peru a new naval mission following the withdrawal of the Leguía-era mission in 1933. In 1937, as the exigencies of hemispheric defense tipped the scales in favor of finally sending a new mission, U.S. policymakers had to weigh the border situation carefully as they considered whether or not to accede to Peruvian desires for a naval mission equipped with command authority. Washington had already agreed to send a strictly advisory two-man naval mission to Ecuador the year before. ${ }^{12}$ The fear was that if the mission sent to Peru could in any way be construed as more than advisory in nature, it could enflame the already very delicate situation.

Peruvian officials were persistent in the face of American reluctance. The Peruvian Navy, which was the driving force behind the nation's renewed push for a U.S. naval mission, was insistent on the issue of executive authority. Captain Saldías, one of the main advocates for reestablishing the mission (and a man that U.S. officials expected to be

\footnotetext{
${ }^{11}$ This description of the origins of the Peru-Ecuador boundary dispute is based on Robert L. Scheina, Latin America's Wars: The Age of the Professional Soldier, 1900-2001, 1st ed. (Washington, D.C.: Brassey's, 2003), 114-17.

${ }^{12}$ According to a "Strictly Confidential" October, 1937 State Department report on "The Armaments Situation in the Other American Republics," two retired U.S. naval officers had been sent to serve as "instructors and advisers" to the Ecuadorian Navy in September, 1936, along with two other Americans who were "advisers and teachers" in that nation's aviation service. See "The Armaments Situation in the Other American Republics," October 13, 1937, RG 59, File 810.20/53A, National Archives.
} 
appointed Minister of Marine once a new U.S. mission was in place), gave the previous U.S. naval mission "unstinted credit" for all the advances that had been made in the Peruvian Navy since 1920, and believed that a new mission would need to be equipped with similarly broad powers in order to continue moving the institution forward. ${ }^{13}$ Because of this, word that any new U.S. mission would act in a strictly advisory and consultative capacity came as a "keen disappointment" to Peruvian naval authorities. "Unless the definition of what constitutes advisory and consultative capacity can be given a liberal interpretation" that would ensure it had some supervisory authority, U.S. Naval Attaché Frank Loftin reported in August, the Peruvians would rather have no mission at all. As a practical matter, they feared that a number of the roles they wanted U.S. officers to fill, such as a "naval constructor" to operate the nation's dry docks and a supply officer to oversee the Navy's expenditures, could not function properly without the authority to make command decisions. ${ }^{14}$ Beyond this, though, was a more deeply-seated problem that had roots in the Leguía era. As Loftin reported in October, a "peculiar situation" existed in the Peruvian Navy whereby a majority of the officer corps (junior to mid-level officers) had been "brought up" either under the direct tutelage of the previous U.S. mission or under the influence of the practices that that mission had left in place. Among these officers, the "great influence and high standards" of the earlier U.S. mission were still felt. The Navy's highest ranks, though, were filled with a number of officers whose training predated the Leguía-era mission, and some who had seen that mission as an unwarranted intrusion. Peruvian authorities up to and including President Benavides feared, Loftin noted, that any "advice" an advisory or consultative naval mission

\footnotetext{
${ }^{13}$ Saldías' view is characterized in U.S. Chargé d'Affaires in Peru to Secretary of State, July 14, 1937, RG 59, File 823.30/213, National Archives.

${ }^{14}$ U.S. Naval Attaché, Lima, Peru to Director of Naval Intelligence, August 20, 1937, RG 38, Entry 48-A, Box 4, National Archives.
} 
might offer to these senior officers "would not fall on very fertile ground." Again, he stressed, Peruvian advocates of a new naval mission expressed that they would rather have "no mission at all" rather than one ill-prepared to deal with this hard reality. ${ }^{15}$

As it appeared unlikely in the waning months of 1937 that they would get a U.S. naval mission that conformed to their desires, Peruvian authorities resorted to a negotiating tactic that Leguía had often employed to strengthen his hand vis-à-vis the United States in the 1920s: playing on U.S. fears of growing European influence in Latin America. The difference was that now, in the late 1930s, the Peruvian hand was stronger because Washington saw European encroachment in the hemisphere as more than an abstract commercial or strategic challenge, as it had in Leguía's day. The presence of German or Italian naval, military, or aviation missions in Peru or any other South American country could imperil inter-American unity and open the hemisphere to the threat European aggression. Given that, Loftin's mid-October report was especially alarming. It seemed to confirm what U.S. officials had feared coming out of the Inter-American Technical Aviation Conference: the Peruvian government had concluded a contract with Italy for a five-member aviation mission - a development, he noted, that "naturally bodes no good" for the prospect of a U.S. naval mission in Peru. ${ }^{16}$ At the same time, word filtered into Washington from Captain Saldías that the British government had recently offered Peru a naval mission. The U.S. Ambassador to Peru, Laurence Steinhardt, saw the timing of this latest information as suspicious. As he wrote Secretary of State Cordell Hull, the fact that the Peruvians revealed the British offer at the very time that a "hitch" over executive authority had emerged in the

\footnotetext{
${ }^{15}$ U.S. Naval Attaché, Lima, Peru to Director of Naval Intelligence, October 2, 1937, RG 38, Entry 48-A, Box 4, National Archives.

${ }^{16}$ U.S. Naval Attaché, Lima, Peru to Director of Naval Intelligence, October 15, 1937, RG 38, Entry 48-A, Box 4, National Archives.
} 
negotiations for a U.S. naval mission "cast grave doubt on the truthfulness" of the report. However, he noted, the recent "intense and open" efforts of Italy to penetrate the Peruvian aviation establishment, and President Benavides' well-known affinity for European military practices, created a "basis for the remote possibility" that the report of a British offer was true. ${ }^{17}$ Despite the apparent transparency of the Peruvian maneuver, the prospect of another non-American mission to Peru - even a British one - on top of the newly contracted Italian aviation mission amounted to an unacceptable challenge to U.S. leadership in hemispheric security. In that sense, the Peruvian tactic had the effect its architects had desired. As Under Secretary of State Sumner Welles noted while bringing naval mission negotiations with Peru to a successful close that December, naval missions were "an increasingly important factor" in U.S. inter-American policy, and it would be exceedingly unfortunate should Peru or Ecuador "for lack of ability on our part to meet their wishes, decide to engage either Italian or German missions."

Finalizing an agreement to send a naval mission to Peru therefore became a high priority in Washington by the end of 1937, so much so that officials in the State Department reconsidered their reservations about allowing naval mission members to assume some form of "executive authority." The Peruvian position remained unchanged. As Peruvian Ambassador to the United States Manuel de Freyre y Santander wrote to Welles in midDecember, officials within Peru's Navy felt deeply that the overall usefulness of a U.S.

\footnotetext{
${ }^{17}$ U.S. Ambassador to Peru to Secretary of State, October 4, 1937, RG 59, File 823.30/215, National Archives. In a lone (unattached and unnumbered) note dated October 16, Selden Chapin of the State Department's Division of the American Republics (as the Division of Latin American Affairs had been re-designated) wrote that Steinhardt was "inclined to believe that this [report of a British offer]," while confirmed, was nevertheless "a rather disingenuous attempt to hasten the negotiations (for an American naval mission) in Washington to a speedy conclusion."

${ }^{18}$ Under Secretary of State to Laurence Duggan (Chief, Division of the American Republics), December 17, 1937, RG 59, File 823.30/220-1/2, National Archives.
} 
mission would be "seriously curtailed" if its officers lacked the authority to ensure that their recommendations were followed. Given the division that existed within the Peruvian Navy's officer corps, the mission needed to be well-positioned to deal with the prospect that its suggestions - which could run "counter to the interests or bias of certain interested parties" within the institution - would be ignored by more senior leaders if all the U.S. personnel could do was "advise." In the naval mission agreements concluded during the Leguía years, Freyre noted, no formal mention had been made of the terms "advisory" or "executive" even though U.S. officers were empowered with command authority. Would it be possible to find a formula to obviate the "current difficulty," the ambassador wondered? ${ }^{19}$

Washington's concerns about allowing U.S. personnel to assume command of Peru's Navy, as expressed earlier by ONI Director Holmes, had not gone away: such an arrangement could still potentially enflame tensions with Ecuador, and could stunt the longer-term development of the Peruvian Navy as an institution. Moreover, memories of the complications such an arrangement had wrought during the Leguía years remained. Unwilling to accede completely to Peruvian wishes but recognizing that Washington had to give ground in order to get the mission underway, Welles proposed a compromise. To ensure that the advice they dispensed had the necessary degree of authority, mission members' contracts with the Peruvian government should be worded so as to make them "responsible solely to the Minister of Marine of Peru." And unlike the Leguía-era arrangement, in which U.S. officers were granted a higher rank in the Peruvian Navy than they held in the U.S. Navy and were accorded seniority over all Peruvian officers of equal rank, Welles proposed that in the new mission, each American officer's "precedence with

\footnotetext{
${ }^{19}$ Peruvian Ambassador to the United States to Under Secretary of State, December 16, 1937, RG 59, File 823.30/220, National Archives.
} 
respect to Peruvian officers shall be according to seniority.” In other words, U.S. personnel would have a line of authority that came directly from the Minister of Marine, but would not automatically have seniority over their Peruvian counterparts. The net effect of such an arrangement, he believed, was that mission members would be able to exercise "a substantial amount" of executive authority "without raising the awkward situation resulting from placing a foreign officer in actual 'command' of Peruvian units." The decisions and recommendations made by U.S. personnel would therefore have the weight of executive authority, even though the orders carrying those recommendations to fruition would be issued through the Navy's senior Peruvian officer. ${ }^{20}$

This arrangement underscores two important realities about U.S. efforts to foster inter-American solidarity and ensure a sound hemispheric defense in the late 1930s. First, it demonstrates that while the United States was eager to send missions to Latin American nations, it wanted to ensure that those missions would be seen as helping hands rather than as intrusions into their internal affairs. In this way the American approach to sending naval missions in the late 1930s had been clearly conditioned by the State and Navy Departments' shared desire to avoid the types of complications posed by the Leguía-era mission to Peru, as well as by the Roosevelt administration's commitment to principles of non-interference in the internal affairs of Latin American "good neighbors." Among the clearest expressions of this is the fact that all naval mission contracts the United States signed with Latin American nations in the late 1930s specified that American personnel would retain their rank in the U.S. Navy and wear only their own nation's uniform. At the same time, the contracts the United States and Peru concluded reflect the fact that, in the interests of securing Latin

\footnotetext{
${ }^{20}$ Under Secretary of State to Peruvian Ambassador to the United States, December 26, 1937, RG 59, File 823.30/220, National Archives.
} 
American cooperation, the United States was willing to tailor the security assistance it

offered to meet the needs identified by partner nations - even if, as in the Peruvian case, that meant treading on slightly uncomfortable ground. ${ }^{21}$ Whereas naval mission agreements with such nations as Colombia and Brazil clearly identified mission members' duties as strictly advisory in nature, the Peruvian contract was written in a more open-ended manner that allowed the "question of exactly how much command may be exercised in an advisory capacity" to be, as State Department Latin America chief Laurence Duggan recognized, "left for adjustment" when members of the U.S. mission arrived in Peru. ${ }^{22}$

\footnotetext{
${ }^{21}$ Wary of seeing the new naval mission repeat the mistakes of the past, especially given Peru's problems with Ecuador, Under Secretary of State Sumner Welles sought to contain any spillover effects by 1) insisting that the mission be established by individual contracts concluded between U.S. naval officers and the Peruvian government rather than by formal agreement between the two nations' governments, and 2) instructing the Division of the American Republics and the U.S. Embassy in Lima that U.S. personnel serving in the mission were to be referred to as "United States Naval Advisers" rather than as members of a formal U.S. "naval mission." He instructed Laurence Duggan of the Division of the American Republics to "endeavor to avoid the use of this expression in the press releases and in the telegram to Ambassador Steinhardt." See Division of the American Republics Memorandum (approved by Welles), January 28, 1938, RG 59, File 823.30/225, National Archives.

${ }^{22}$ According to the contract concluded by the United States and Colombia in November, 1938, the stated purpose of the U.S. naval mission to that nation was "to cooperate in an advisory capacity with the Director General and the officers of the Colombian Navy, wherever desired in Colombia by the Ministry of War, with a view to enhancing the efficiency of the Colombian Navy." Similarly, by contract, the U.S. naval mission to Brazil was to be "subordinate" to the Brazilian Minister of Marine, and its duty was "to advise, through the Minister of Marine, the Chief of Staff of the Navy, the Directors of Instruction of the Naval War School, of the Naval Arsenal, of Naval Engineering and of Aeronautics, cooperating with them in all matters within their province, always indicating the necessary measures, as well as the training to be given, for the greater efficiency of the Navy." The contract concluded with Peru was less clear on the nature of mission members' advisory work, stating only that the government of Peru agreed "to employ the services" of an "Advisory Chief of Staff of the Peruvian Navy" and subordinate mission members. See U.S. Department of State, "Naval Mission: Agreement Between the United States of America and Colombia, Signed at Washington November 23, 1938," Executive Agreement Series, No. 140, as well as U.S. Department of State, "Naval Mission: Agreement Between the United States of America and Brazil, Signed May 27, 1936, Effective June 25, 1936," Executive Agreement Series, No. 94. The contract concluded with Peru stated merely that "The Party of the First Part [Peru] hereby agrees to employ the services of the Party of the Second Part [the United States] as Advisory Chief of Staff of the Peruvian Navy, subject to the conditions set forth in this Agreement." No more precise statement of the mission's advisory nature was made. See Office of Naval Intelligence to Department of State, "Contract Between Peru and the United States," December 17, 1937, RG 38, Entry 48-A, Box 5, National Archives. For Duggan's commentary, see Head, Division of American Republics to Under Secretary of State, December 20, 1937, RG 59, File 823.30/221, National Archives. For more on the agreement Washington concluded with Colombia, see Coleman, Colombia and the United States: The Making of an Inter-American Alliance, 1939-1960, 19-20.
} 


\section{THE NAVAL MISSION AND HEMISPHERIC DEFENSE}

From the point of view of substantive naval reform, the naval mission's accomplishments in Peru during the two year period covered by the initial contract (19381940) disappointed both Americans and Peruvians. However, from the U.S. perspective, the mission's real value during those years was not the work it did (or did not do) to overhaul the Peruvian Navy. Its real value was political - in terms of building inter-American solidarity, the important thing was that the mission was there, serving as a clear indication of U.S. resolve. ${ }^{23}$ Cognizant of the successes their predecessors in the first naval mission had had in Peru between 1920 and 1930, members of the mission nevertheless had high expectations for their work. Those expectations were dashed by reality. Early in the mission's tenure its chief, Bruce L. Canaga (Captain, U.S. Navy), wrote to his superiors in ONI that members' lack of fluency in the Spanish language hampered their work. Only one member of the mission, Emory D. Stanley (Captain, U.S. Navy) was proficient in the language, having served in the Leguía-era U.S. naval mission. ${ }^{24}$ It was "a darned big handicap," Canaga wrote, and a marked departure from that earlier mission, many of whose officers, if not

\footnotetext{
${ }^{23}$ That the State Department was not overly concerned with the substantive work done by the naval mission to Peru is borne out by the fact that, in State Department records, there are no reports of naval mission activity for the years 1938 and 1939. During the Leguía-era naval mission's tenure, such reports were commonplace. Similarly, for 1938 and 1939 there are very few reports of naval mission activities in the records of the Office of Naval Intelligence, which had responsibility for overseeing the mission. The only substantive reports of the naval mission's work during these years are brief, periodic handwritten letters from Captain Canaga - reports that lack much detail.

${ }^{24}$ A Department of the Navy press release announcing the members of the new U.S. naval mission to Peru noted that Stanley served in the Leguía-era mission from 1922 to 1926. Department of the Navy Press Release, February 5, 1938, RG 59, File 823.30/227, National Archives.
} 
completely fluent, were sufficiently competent in the language to carry out their work effectively. $^{25}$

The larger problem confronting the mission, Canaga believed, was the Peruvian Navy's seemingly chronic shortage of funds. It was the constant theme of Canaga's communications to Washington. The age and relative disrepair of Peru's naval ships, which limited all-important training at sea, was a source of great frustration to mission members and Peruvian personnel, as was the Peruvian Navy's inability to accept a 1938 invitation from Washington to send officers and cadets to study at naval schools in the United States. "These people have no money to send students to the U.S.," Canaga wrote to ONI disappointedly, "and they can't find it so it is just a plain pain in the neck." The situation was so frustrating that in a moment of exasperation Canaga concluded that "when another comes along looking for my job they can have it -6 hours notice is all I need." 26 The Navy's funding problems represented a marked departure from the Leguía years, when, because of plentiful foreign loans and the president's own fondness for the Navy, the institution had enjoyed relatively plentiful budgets. For Canaga and his colleagues, the legacy of that earlier mission's successes, aided substantially as they had been by abundant resources and direct presidential support, seemed to obscure any memory of the problems that had often attended its work. The achievements of the Leguía-era mission hung over the new U.S. naval mission in 1938, and caused its members to become frustrated with their inability to produce similarly impressive results.

\footnotetext{
${ }^{25}$ Head of U.S. Naval Mission to Peru (Canaga) to ONI, June 12, 1938, RG 38, Entry 48-A, Box 5, National Archives.

${ }^{26}$ Head of U.S. Naval Mission to Peru (Canaga) to ONI, February 1, 1939, RG 38, Entry 48-A, Box 5, National Archives.
} 
The lack of results was frustrating also to Peruvian authorities, who continued to push Washington to permit the mission to assume broader authority over their naval establishment. When Duggan, the State Department's Latin America chief, visited Lima for the Eighth International Conference of American States in December of 1938, the issue of executive authority was the first thing the Peruvian delegation wanted to address with him. Captain Saldías, by then Peru's Minister of Marine, pushed him on the issue during a face-to-face meeting, and shortly afterward addressed a detailed aide-memoire pressing his case even further. There was a consensus among Peru's president, cabinet ministers, and a majority of the Navy's officers, he stressed, that it was "most necessary" that the U.S. naval mission be clothed with executive authority. For them, as for Canaga and his naval mission colleagues, the "past experience" of the Leguía-era mission had set a high standard for success. "With the old equipment we have and with the changes in regime" that were expected with Benavides' decision not to seek reelection in 1939, it was "most necessary" that Peru's naval policy be "fixed so it cannot be altered by a new government." This could only be done, he insisted, if obstinate senior-level officers were cut out of institutional decision-making and replaced by U.S. personnel. The assumption by U.S. officers of executive authority was particularly necessary at the Escuela Naval, the Minister argued, where in years past Captain Charles G. Davy's leadership had effected a far-ranging transformation in Peruvian officer education. Peru wanted to see such innovative work resume, including the importation of curriculum, texts, and practices from the U.S. Naval Academy. Such reforms could only be assured of success if an American officer was again placed in charge at La Punta. Saldías augmented his case for executive authority by again demonstrating his government's willingness to play on U.S. fears of growing European influence in Peru. His government 
desired greater cooperation with the U.S. Navy in aviation, he noted, both by sending Peruvian pilots to train in the United States and by contracting for an American naval aviation mission to undertake education and training in Peru. Saldías wrote that he was "most anxious" to conclude agreements with Washington on both fronts, but took care to note that the Italian government, which already maintained an aviation mission in the country, had recently offered to expand the number of Peruvian pilots invited to train in Italian military aviation schools. It would be most embarrassing, he stressed, for Peru to refuse the Italian offer if it did not have a compelling American alternative. At the same time, he concluded, there were no doubt significant efficiencies to be gained by having both naval and naval aviation missions from the same country. ${ }^{27}$

Peruvian persistence helped carry the day. In early 1939 the State and Navy Departments began to seriously entertain the idea of allowing the naval mission to Peru to assume broader authorities over the Peruvian Navy. But the larger force moving Washington's hand was growing concern over hemispheric security. As historian Max P. Friedman has noted, by late 1938 the Roosevelt administration believed "the most immediate security threat" facing the United States was the possibility of German destabilization of Latin American governments. ${ }^{28}$ Reports to that effect aroused considerable concern within the State Department and the White House. In November of that year Breckinridge Long, Roosevelt's former ambassador to Italy, reported finding strong evidence of active Nazi efforts to foment "political insurrection" in Brazil and Argentina during a regional fact-

\footnotetext{
${ }^{27}$ In the course of this wide-ranging aide-memoire, Saldías noted that "Seventeen of our Aviation Cadets are being trained in Italy at a cost of $\$ 550$ per year. Italy wishes to get more Cadets and makes excellent offers, some 40 Cadets desired for 1939." Saldías Aide-Memoire to Laurence Duggan, January 5, 1939, RG 38, Entry 48-A, Box 5, National Archives.

${ }^{28}$ Max Paul Friedman, Nazis and Good Neighbors: The United States Campaign Against the Germans of Latin America in World War II (Cambridge; New York: Cambridge University Press, 2003), 2.
} 
finding mission for the White House. ${ }^{29}$ Among the evidence Long collected was a German dispatch that the Brazilian government had intercepted between a retired German General living in Brazil and Nazi Foreign Minister Joachim von Ribbentrop in Berlin. The message was that "preparation for the armed movement is already well initiated," and informed Berlin that "a good network of resident agents" existed in the southern Brazilian states of Minas Gerais, Sao Paulo, and Paraná. In Sao Paulo alone, the general estimated, the network's "effectives" comprised more than 35-percent of the population and included Germans, Japanese, Italians, and Brazilians. Should those agents be successful in fomenting a civil war, he assured, the pro-Nazi presence meant that "everything will take care of itself." 30 This report was particularly alarming to Roosevelt, who received it on December 15th and brought it to the attention of his cabinet the very next day. Subsequently he had Welles cable Secretary of State Cordell Hull, already in Lima for the Eighth International Conference of American States, instructing him to pursue a declaration of all states in attendance that they "shall not permit any non-American state to assist or abet in the fomenting of internal disorder in any American republic." ${ }^{31}$ U.S. efforts at Lima to secure such a wide-ranging inter-American commitment were stymied, as they had been at Buenos Aires two years earlier, by Argentine resistance. The Declaration of Lima produced by the conference contained a weaker statement of inter-American solidarity than Roosevelt had hoped. ${ }^{32}$ But

\footnotetext{
${ }^{29}$ Secret Report of Breckinridge Long to Franklin D. Roosevelt, November 18, 1938, President's Secretary's File, Box 50, Franklin D. Roosevelt Presidential Library, Hyde Park, NY.

${ }^{30}$ Under Secretary of State Sumner Welles to Franklin D. Roosevelt, December 15, 1938, Sumner Welles Papers, Box 150, Franklin D. Roosevelt Presidential Library, Hyde Park, NY.

${ }^{31}$ Dominic Tierney, FDR and the Spanish Civil War: Neutrality and Commitment in the Struggle that Divided America, American Encounters / Global Interactions (Durham: Duke University Press, 2007), 82-83.

${ }^{32}$ Secretary of State Cordell Hull had gone to Lima intent on securing a commitment from the other American Republics "to resist any threat, either direct or indirect, to their peace, safety, or territorial integrity on the part of any non-American country." As he had at Buenos Aires two years earlier, though, Hull encountered spirited resistance from Argentina. In the end, as Robert Dallek notes, at Lima the United States settled for "a non-
} 
in the wake of the disappointment, the alarming reports that continued to emanate from South America moved the administration to step up its efforts at military and naval cooperation on the continent. The next month, as 1939 dawned, the inter-agency working group of the State, War, and Navy Departments that the administration had formed to coordinate the government's hemispheric defense efforts (an entity known as the Standing Liaison Committee, or SLC), discussed the apparent acceleration of Nazi efforts to subvert South American governments and began weighing options to combat it.

Chaired by Sumner Welles, the committee was especially worried that large German populations in South America, especially in Argentina, Uruguay, and Chile, could be pushed into cooperating with Nazi military efforts to overthrow established governments on the continent. Welles believed that such prospects were "unfortunately not remote possibilities." ${ }^{33}$ It was against this backdrop that, at the same January meeting, the committee weighed options for expanding U.S. naval and military cooperation in South America. The priority in such cooperation went to countries such as Peru that, like the countries in question, also had substantial European populations. Accordingly, the first issue the SLC took up after discussing the recent revelations of German subversive efforts in

binding declaration...to defend the principles of American continental solidarity against all foreign threats: should the peace, security, or territorial integrity of any American Republic be threatened, the Conference announced, the American states would share a 'common concern' and would 'make effective their solidarity'." See Dallek, Franklin D. Roosevelt and American Foreign Policy, 1932-1945: With a New Afterword, $176-77$.

\footnotetext{
${ }^{33}$ Although the charter of the Standing Liaison Committee states generally that its purpose was the "coordination of the basic established policies of this Government which affect the three departments concerned," its main function was to coordinate U.S.-Latin American military cooperation. Section IV of its charter states that "The Department of State considers it most imperative to undertake immediately a reappraisal of the policies of this Government with respect to cooperation in military and naval matters with the other American republics." See "The Proposed Standing Liaison Committee of the State, War, and Navy Departments," March, 1938, RG 353 (Records of Interdepartmental and Intradepartmental Committees), Entry 12, Box 3, National Archives. President Roosevelt "heartily" approved of the creation of the SLC. See President Roosevelt to Under Secretary of State Sumner Welles, April 4, 1938, Sumner Welles Papers, Box 150, Franklin D. Roosevelt Presidential Library, Hyde Park, NY. For additional context, see Stetson Conn and Byron Fairchild, The Framework of Hemisphere Defense, United States Army in World War II: The Western Hemisphere (Washington, DC: Office of the Chief of Military History, Deptartment of the Army, 1960).
} 
Brazil was the granting of executive control to the U.S. naval mission in Peru. In their deliberations, committee members were impressed by the case made by Minister Saldías in his aide-memoire to Laurence Duggan. Allowing U.S. officers to assume command of the Peruvian Navy could certainly put them "in a very difficult position," Chief of Naval Operations William Leahy noted, but the rewards of such an arrangement could be worth the risks - especially if it paved the way for the establishment of a U.S. naval aviation mission to replace the Italian aviation mission whose contracts would expire later that year. The other SLC principals, Welles and Army Chief of Staff Malin Craig, agreed, provided that such expanded authority be accompanied by a broad "escape clause" protecting U.S. personnel from the kinds of entanglements that beset the Leguía-era naval mission. U.S. officials remained insistent that American personnel not become involved in any foreign war or civil disturbance during their duty in Peru. Yet given the prevailing threat to the Western Hemisphere, they were now open to assuming some risk in that regard. ${ }^{34}$ In retrospect it was a bold move because a war between Peru and Ecuador remained a reasonable possibility. A settlement of the two countries' border dispute remained elusive and tensions still simmered. Nevertheless, after two years of near-constant pressure from the Peruvian government, the United States seemed poised to accede to the Peruvian desire to grant the naval mission executive powers.

It was a change supported by mission members themselves, though U.S. Navy leaders in Washington viewed it with skepticism. For naval mission chief Bruce Canaga, executive authority held the promise that U.S. personnel could achieve more successful outcomes in their work. In March 1939 he had voiced opposition to the idea, writing to ONI that "it

\footnotetext{
${ }^{34}$ Minutes of the Meeting of the Standing Liaison Committee, January 21, 1939, RG 353, Entry 10, Box 1, National Archives.
} 
doesn't make any difference how hard one works" in Peru - "if you turn your back they go back to type and there is no money for the Navy." 35 But throughout that year his mounting frustration with the mission's lack of results, which he blamed on chronic budget shortfalls and the intransigence of resentful senior-level officers, convinced Canaga that having greater control could yield better results. In August he wrote to ONI that the persistence of the situation in Peru had "very much changed" his view. In order to fulfill the mission's original charge of "fending off the European powers," he wrote, mission personnel needed to be in a position "to force our ideas" because, as advisors, mission members' recommendations often did "not get a whole long ways" through Peru's naval bureaucracy. The reasons for this, in his estimation, were as clear as ever: a scarcity of money made it impossible to operate with more than the "really vital necessities," he argued, while senior officers consistently failed cooperate in carrying out the mission's recommendations. Behind Canaga's frustration, though, were doubts that Peruvians could effectively manage their own affairs. Explaining his change of heart on the issue of executive authority, he wrote that "As long as I thought that it would be possible to teach these people anything I was against that [assuming executive authority]." But now, after nearly a year and a half on duty in Peru, Canaga concluded that Peruvians were incapable of ever improving their Navy on their own. Having Americans assume control of Peru's Navy was, in his view, "the only way to get real efficiency." ${ }^{36}$ Yet Canaga's superiors in ONI were not convinced. By then the State Department had already withdrawn its opposition to letting the mission assume executive authority. In the face of the threat of Nazi aggression in the hemisphere, U.S. policy deemed

\footnotetext{
${ }^{35}$ Head of U.S. Naval Mission to Peru (Canaga) to ONI, March 21, 1939, RG 38, Entry 48-A, Box 5, National Archives.

${ }^{36}$ Head of U.S. Naval Mission to Peru (Canaga) to ONI, August 7, 1939, RG 38, Entry 48-A, Box 5, National Archives.
} 
the rewards of closer naval cooperation with Peru to be worth the risks. But the concerns ONI Director R.S. Holmes had raised nearly two years earlier remained valid, ONI leaders insisted. Placing Americans in command of a Peru's naval establishment could enflame the Peru-Ecuador border situation, they cautioned, and could unwittingly align the United States too firmly with one or more particular political factions within Peru. While it was the U.S. Navy's job to help carry out American foreign policy and not to make it, ONI leaders believed, it seemed distinctly within the realm of possibility that a grant of executive authority could lead to a replay of some of the significant challenges posed by the Leguía-era mission. $^{37}$

Yet in the face of a growing threat to hemispheric security, foreign policy considerations outweighed the kinds of concerns expressed by ONI. At the same time that it embraced executive authority for the U.S. naval mission in Peru for political reasons, the Roosevelt administration was busy expanding the number, size, and scope of its naval and military missions throughout Latin America. For example, in its February 1939 meeting the SLC discussed the desirability of expanding the U.S. naval mission to Brazil. The hope was that that mission, established in 1936 mainly to advise the Brazilian Naval War College, could get involved in making more substantive improvements to the Brazilian Navy. ${ }^{38}$ In April the Committee fielded a request from the Colombian government to send up to twenty additional personnel to the U.S. naval mission there, with an emphasis on officers expert in

\footnotetext{
${ }^{37}$ An ONI commentary contained as addendum on Canaga's August 7th letter notes that "State has reversed itself officially in writing since Admiral Holmes letter was written, having withdrawn its objection to granting executive authority to missions. The other objections pointed out by Admiral Holmes still appear to be valid, particularly in view of the experience of the first mission which had executive authority." See ONI routing slip attached to Head of U.S. Naval Mission to Peru (Canaga) to ONI, August 7, 1939, RG 38, Entry 48-A, Box 5, National Archives.

${ }^{38}$ Minutes of the Meeting of the Standing Liaison Committee, February 8, 1939, RG 353, Entry 10, Box 1, National Archives.
} 
aviation. ${ }^{39}$ Chief of Naval Operations William Leahy feared such developments. If the mission in Colombia were expanded, he argued, then other Latin American nations would undoubtedly demand similar treatment. Welles, however, citing Colombia's "special position" in the Americas, expressed unhesitating approval. ${ }^{40}$ Deeper naval-military cooperation with South American nations, he believed, would yield both practical benefits and political benefits for Washington's inter-American policy.

In key cases like Brazil and Colombia, such aid could help improve navies that the Roosevelt administration believed could make real contributions to a U.S.-led defense of the Americas, while closer naval and military links with other South American nations, whose militaries were less likely to contribute operationally, would nevertheless burnish Washington's political efforts to build solidarity among the American republics. The political imperative became even more important after the outbreak of war in Europe in early September 1939. That month the SLC decided the United States should offer naval and military missions to all Latin American nations that were losing European missions to the exigencies of the war. ${ }^{41}$ One such nation was Peru's southern neighbor, Chile, part of the continent's "southern cone" that had historically maintained close naval and military ties with Great Britain and Germany. ${ }^{42}$ At the September meeting of the SLC, Welles reported that the Roosevelt administration had just received a request for "assistance of a practical kind" from Chile to improve its Navy and Army. It was the first time Chile had sought such

\footnotetext{
${ }^{39}$ Minutes of the Meeting of the Standing Liaison Committee, April 1, 1939, RG 353, Entry 10, Box 1, National Archives.

${ }^{40}$ Minutes of the Meeting of the Standing Liaison Committee, July 26, 1939, RG 353, Entry 10, Box 1, National Archives.

${ }^{41}$ Minutes of the Meeting of the Standing Liaison Committee, September 13, 1939, RG 353, Entry 10, Box 1, National Archives.

${ }^{42}$ Scheina, Latin America: A Naval History, 1810-1987, 138-39.
} 
assistance from Washington, he noted, and he recommended that the Committee do everything within its power to respond favorably to the request. Underscoring the political value of assistance to such nations, Welles called Chile "the last link in our South American chain." 43

The outbreak of war in Europe and subsequent developments in inter-American affairs confirmed the essentially political function of the U.S. naval mission in Peru. Members of the mission continued to judge their progress against the advances made by their Leguía-era predecessors, and focused on making substantive improvements to the Peruvian Navy. However, they found their efforts held in check when they ran counter to the thrust of U.S. hemispheric policy. In late September, just weeks after Hitler's Wehrmacht had stormed into Poland, representatives of all the American republics gathered in Panama to assess the war's impact on the Americas. Delegates to the meeting unanimously approved a general statement of neutrality, established mechanisms to boost inter-American trade, and most importantly, created an offshore buffer zone of between three hundred and one thousand miles around the Americas that was to be "free from the commission of any hostile act by any non-American belligerent." ${ }^{44}$ The zone was to be patrolled jointly by the navies of the American republics. However, most Latin American nations lacked the naval power to make meaningful contributions to its enforcement. ${ }^{45}$ It was a problem that many Latin American nations, interested in improving their military establishments, would aim to address during the war years.

\footnotetext{
${ }^{43}$ Minutes of the Meeting of the Standing Liaison Committee, September 13, 1939, RG 353, Entry 10, Box 1, National Archives. See also Division of the American Republics Memorandum, November 22, 1939, RG 59, File 823.30/242 1/2, National Archives.

${ }^{44}$ Dallek, Franklin D. Roosevelt and American Foreign Policy, 1932-1945: With a New Afterword, 205.

${ }^{45}$ Scheina, Latin America: A Naval History, 1810-1987, 144.
} 
Many nations, Peru among them, saw in the war an opportunity to gain U.S. support for their military and naval plans under the banner of hemispheric defense. In late 1939 Captain Canaga, whose frustrations with the mission's lack of impact throughout its first year and a half were well known in Washington, gave voice to the Peruvian Navy's aspirations by drafting a reform program calling for new ships and equipment as well as substantial increases in annual appropriations. Even though the U.S. mission was equipped with executive authority, his memorandum stated that it would be a waste of Peruvian resources to maintain the naval mission without giving the Navy the resources required "to justify the work of the mission." The plan specified appropriations of four to five million dollars per year as the minimum needed to achieve a meaningful overhaul of the Peruvian fleet. Mindful of the diplomatic difficulties that had attended naval mission chief Clark Woodward's proposed naval buildup in 1923, the State Department put an end to Canaga's effort before the officer could even present his recommendations to Peru's Minister of Marine. Such high naval expenditures would place an undue burden on the already strained finances of Peru's government, embassy staffer George Butler wrote to Sumner Welles in Washington. Beyond that, he continued, permitting the U.S. naval mission to guide a buildup of the Peruvian Navy at that moment could endanger American aims for hemispheric defense. Outside of perhaps Brazil and Argentina, Butler argued, U.S. assistance to South American navies could only serve to improve their effectiveness against neighboring countries and would yield no real benefits for a broader U.S.-led defense of the Americas. The risk was that by extending such help, the United States could embolden countries with longstanding grievances against neighbors to resort to force. To the Roosevelt administration, peace and tranquility throughout the hemisphere was essential to ensuring that the Americas could withstand a 
possible assault by Germany. Tensions among Latin American nations, such as those that lingered between Peru and Ecuador, were seen as possible threats to inter-American unity. Butler's memorandum underscored the administration's position that American naval and military missions should do nothing to raise tensions in South America. Such missions had "a distinct political value apart from their technical work," he stressed, and in countries like Peru, whose Navy operated under "serious handicaps," the "political aspect...may be more important than [the naval mission] doing the best professional job." Certainly it was "most desirable to maintain the mission and to do the best possible job under existing conditions," he added, for mission members could "do much toward assuring discipline, good organization and honesty in administration" in the Peruvian Navy without jeopardizing Washington's inter-American policy. But in Peru as in so many other Latin American countries, the "political aspect" was of overriding importance. ${ }^{46}$ Sumner Welles and Laurence Duggan, the State Department's leading voices on Latin American issues, agreed. ${ }^{47}$ In short, Butler's message confirmed, the work of naval and military missions in Peru, and throughout Latin America, was fundamentally diplomatic. Appearances were key.

\footnotetext{
${ }^{46}$ In this remarkable memorandum, Butler offered one of the clearest statements found anywhere in State Department or Navy records on U.S. naval and military assistance to Latin America during the World War II years. He wrote that "it seems to me that our missions must necessarily have widely different objectives in the respective countries. In Brazil and Argentina they might shoot the works and aim at doing a first rate professional job. But a naval or aviation mission in Ecuador - or even in Peru or Chile under present conditions - must start out under serious handicaps. The material to work with simply does not exist. It seems to me that the political aspect is the most important one in such cases." George Butler, First Secretary of U.S. Embassy to Laurence Duggan, October 20, 1939, RG 59, File 823.30/243 1/2, National Archives.

${ }^{47}$ In a memorandum to Welles commenting on Butler's dispatch from Lima, Duggan wrote "However irksome it may be to the officers on details to these countries not to have sufficient equipment with which to do a good professional job, nevertheless there is a very important political value in having these missions in these countries. Their mere presence in times like these can contribute to the development of opinion in support of the things which the American countries consider valuable, as set forth in the preamble of the Declaration of Lima. It does seem desirable and important, therefore, that the members of our missions have an understanding of the larger role that they can play in these countries in order that they not become restless and recommend huge military expenses to the disadvantage of trade and investment interests." See Laurence Duggan to Sumner Welles, October 30, 1939, RG 59, File 823.30/243 1/2, National Archives.
} 
Within the bounds set by the State Department, U.S. naval cooperation with Latin American nations intensified as the perceived threat to the Americas grew throughout 1940 . At the beginning of that year, the U.S. goal was to signal inter-American unity by renewing all existing naval and military mission contracts that were set to expire, and to secure new mission agreements in as many Latin American countries as possible. In Peru, this meant negotiating a longer-term contract to keep the U.S. naval mission in place and, in accordance with Peruvian wishes, formalizing its executive powers over that nation's Navy. Deliberations over the naval mission's renewal dragged on from January through April with little in the way of concrete progress, though, as American officials weighed Peruvian requests that the United States defray its costs by picking up a substantial share of the mission's overall tab. ${ }^{48}$ Meanwhile, the original two-year contract concluded in 1938 expired in March. At that point, military developments in Europe intervened and imparted a new sense of urgency to the negotiations. In the span of little more than six weeks in May and June 1940, German armies overran the Netherlands, Belgium, and Luxembourg en route to conquering France. By the end of June, only Britain stood between Hitler and total domination of Western Europe. ${ }^{49}$ To the Roosevelt administration as to much of the world, the Nazi military machine looked invincible, and the threat it posed to the Western Hemisphere loomed larger than ever. ${ }^{50}$ Worried that continued military success in Europe

\footnotetext{
${ }^{48}$ In November, 1939 Captain Canaga had informed the U.S. Chargé d'Affaires in Lima, Louis G. Dreyfus, that the administration of new Peruvian President Manuel Prado had signaled to him that in all likelihood it would not have funds available to cover the naval mission's operations in 1940, and would seek relief from the United States. See U.S. Chargé d'Affaires in Peru to Secretary of State, November 20, 1939, RG 59, File 823.30/242, National Archives.

${ }^{49}$ Among the best treatments of Germany's campaigns in the spring and summer of 1940 is Williamson Murray and Allan Reed Millett, A War To Be Won: Fighting the Second World War (Cambridge: Belknap Press of Harvard University Press, 2000), 63-90.

${ }^{50}$ In late May, Sumner Welles wrote to Claude Bowers, the U.S. Ambassador to Chile, that "I think there is no doubt that in the event of continued German victory in Europe, German agents in many of the Latin American
} 
might lead Hitler to unleash a strike against the Americas, in July representatives of all the American republics gathered in Havana, Cuba, and agreed that no "new world" European colonies should be allowed to fall into German hands as a result of military developments in Europe. In inter-American naval and military cooperation, time was of the essence.

In the face of what it saw as a grave and growing threat to hemispheric security, the Roosevelt administration was increasingly anxious to conclude the Peruvian naval mission agreement along with a host of others. ${ }^{51}$ In short order U.S. officials agreed to shoulder a larger share of the financial burden not only for its mission in Peru, but for its missions throughout Latin America. ${ }^{52}$ In June 1940 the U.S. Congress passed and President Roosevelt signed legislation expanding the government's authority to "assist the governments of the American republics in increasing their military and naval establishments." ${ }^{\circ 3}$ At the same time, the Roosevelt administration hastened to wrap up an agreement to finally send a naval aviation mission to Peru - something that Peruvian officials, anxious to reconnect with the aviation successes achieved under Commander Grow and the Leguía-era mission, had first

countries will undertake immediately activities with a view to the overthrow of existing governments." See Under Secretary of State Sumner Welles to U.S. Ambassador to Chile, May 24, 1940, Sumner Welles Papers, Box 150, Franklin D. Roosevelt Presidential Library, Hyde Park, NY.

${ }^{51}$ Dallek, Franklin D. Roosevelt and American Foreign Policy, 1932-1945: With a New Afterword, 234-36. Dallek notes that although German documents subsequently revealed that "Roosevelt and most Americans greatly exaggerated the German threat to the Americas" in the summer of 1940, "Hitler's past behavior and growing military capability left Roosevelt little choice but to take all possible precautions against an eventual attack."

${ }^{52}$ In December, 1939 Welles had written to Roosevelt notifying him that the Peruvian government was having difficulty finding sufficient funds to pay for a continuation of the U.S. naval mission in that country. "A withdrawal of our naval mission on whatever ground," he stressed, "would be tantamount to a rejection" of the advances the mission had facilitated in overall U.S.-Peruvian relations, and would open the way for greater European influence within Peru. See Under Secretary of State Sumner Welles to President Franklin D.

Roosevelt, December 16, 1939, FDR Official File, OF-287, Box 1, Franklin D. Roosevelt Presidential Library, Hyde Park, NY.

${ }^{53}$ John Child, Unequal Alliance: The Inter-American Military System, 1938-1978 (Boulder: Westview Press, 1980), 32-33. 
raised in late $1938 .^{54}$ The signing of naval mission and aviation mission contracts with Peru at the end of July 1940 ensured that one of Washington's longest-running military-to-military relationships in the Americas, and one that in many respects had been the test bed for the system of naval and military advising on which U.S. designs for hemispheric defense depended, would continue until the external threats to the Western Hemisphere subsided. ${ }^{55}$ Although its work had often fallen short of the expectations set by the Peruvian Navy and officers of the mission itself, from the point of view of U.S. efforts to build inter-American solidarity, the naval mission's work was a success.

\section{GOODWILL CRUISING AND HEMISPHERIC DEFENSE}

As the Roosevelt administration re-established the U.S. naval mission in Peru and expanded its naval and military advising efforts throughout Latin America in the interests of hemispheric security, it continued to employ the other component of its "good neighbor" naval diplomacy" - goodwill naval cruises and port visits - for the same purpose.

Dependent as its inter-American policy was on communicating U.S. strength and cultivating inter-American accord, it is not surprising that the Roosevelt administration made public demonstrations of American naval prowess in Latin America a priority as hemispheric security concerns began to dominate. The success of naval visits to Latin American ports in

\footnotetext{
${ }^{54}$ In his January, 1939 aide-memoire to Laurence Duggan, Minister of Marine Roque Saldías had reiterated his government's desire for a U.S. naval aviation mission. "Just as soon as it can be arranged," he wrote, "I want to get an Aviation Mission from the United States. These officers I do hope can be given executive authority. With the Italian aviation Mission at present, the system of having a Peruvian officer in charge has been a failure." See Saldías Aide-Memoire to Laurence Duggan, January 5, 1939, RG 38, Entry 48-A, Box 5, National Archives.

${ }^{55}$ See U.S. Department of State, "Naval Mission: Agreement Between the United States of America and Peru, Signed July 31, 1940," Executive Agreement Series, No. 177, and U.S. Department of State, "Naval Aviation Mission: Agreement Between the United States of America and Peru, Signed July 31, 1940," Executive Agreement Series, No. 178.
} 
the earlier years of Roosevelt's presidency had made them an indispensable part of his administration's “good neighbor" diplomacy, and the U.S.S. Ranger's 1937 visit to Lima during the Inter-American Technical Aviation Conference had signaled the utility of such cruises to U.S. efforts at building hemispheric unity. The latter underscored an emerging consensus in the Roosevelt administration: U.S. naval vessels and aircraft plying the waters and skies of Latin America could not only send messages of friendship and good neighborliness, but could also send an undeniable message of U.S. strength and resolve to lead a defense of the Western Hemisphere from external attack. From that point forward, such cruises had a clear role in Roosevelt's efforts to build inter-American solidarity.

As he had earlier in his presidency, Roosevelt himself emphasized the importance of goodwill cruises to his administration's inter-American policy in the late 1930s. The subject of goodwill naval cruises to Latin America was among the first items discussed by the Standing Liaison Committee, for example, at its first meeting in April 1938. During that meeting, Under Secretary of State Sumner Welles advised SLC members that "the President has agreed that part of the fleet should visit the east coast of South America this summer," and that Roosevelt would be taking the issue up directly with the Navy Department. ${ }^{56}$ When the Committee weighed the specifics of that cruise, the centerpiece of which was the aircraft carrier U.S.S. Enterprise, Welles made a clear connection between that carrier's impending visit to South America and the past Latin American cruises of the U.S.S. Ranger, which in his view had set the standard for how such visits should be conducted. In view of the Ranger's successful visit to Lima the year before, Welles noted, a visit to Brazil by the Enterprise without aircraft "might be seen as disappointing" to its Brazilian hosts. Moreover,

\footnotetext{
${ }^{56}$ Minutes of the Meeting of the Standing Liaison Committee, April 26, 1938, RG 353, Entry 10, Box 1, National Archives.
} 
memories of the performance given by the Ranger's aircraft in the skies over Lima during the Inter-American Technical Aviation Conference were still fresh. It would be better from an inter-American policy point of view, Welles concluded, for the Enterprise to embark with a full complement of aircraft and carry out aerial demonstrations wherever practicable. ${ }^{57}$

Roosevelt continued to stress the importance of naval cruises in Latin America into 1939, as U.S. concerns about German subversion in South America grew. In September 1938 he had directed the Navy and State Departments to begin coordinating a springtime visit of a division of cruisers to South America. The president's stated intent was to have the vessels visit ports that he himself had not visited during his own trips to Latin American waters, meaning a great deal of its emphasis would be on west coast ports such as Valparaiso, Chile and Lima, Peru. ${ }^{58}$ In November, as planning for the cruise was just getting underway, Under Secretary of State Sumner Welles alerted the Standing Liaison Committee to yet another "German plot to create trouble in Brazil, Uruguay and Argentina." It was the kind of information that U.S. intelligence assets had been reporting to Washington with increasing regularity in the latter months of 1938, and to Roosevelt, seemed like confirmation of the assessment provided by special emissary Breckinridge Long. ${ }^{59}$ Administration officials, including the president himself, were more and more consumed with what they saw as a gathering Nazi threat in South America. In such a climate, public displays of naval strength in Latin American waters took on even greater importance to U.S. policy. Accordingly,

\footnotetext{
${ }^{57}$ Minutes of the Meeting of the Standing Liaison Committee, May 25, 1938, RG 353, Entry 10, Box 1, National Archives.

${ }^{58}$ Roosevelt had visited Rio de Janeiro, Brazil and Montevideo, Uruguay en route to the Inter-American Conference for the Maintenance of Peace in late 1936, and had made several visits to Caribbean and Central American countries such as Haiti and Panama. Minutes of the Meeting of the Standing Liaison Committee, September 26, 1938, RG 353, Entry 10, Box 1, National Archives.

${ }^{59}$ Secret Report of Breckinridge Long to Franklin D. Roosevelt, November 18, 1938, President's Secretary's File, Box 50, Franklin D. Roosevelt Presidential Library, Hyde Park, NY.
} 
Roosevelt reiterated his desire to send a division of heavy cruisers to South America following springtime naval exercises in the Caribbean. Now, however, for the first time U.S. vessels would circumnavigate the entirety of South America and make a "goodwill" cruise a show of force for the whole continent to behold - beginning at La Guaira, Venezuela, and continuing southward along the east coast before passing through the Straits of Magellan and proceeding up the west coast for large stops in Chile and Peru. ${ }^{60}$

In some respects, the six-week cruise of the U.S. Navy's 7th Cruiser Division that took shape in April and May 1939 was little different than the goodwill cruises that had come before it. At each stop the Division's commander, Husband E. Kimmel (Rear Admiral, U.S. Navy), his staff, and enlisted crew engaged in public diplomacy activities intended to burnish their nation's good neighbor credentials. In large measure these activities conformed to what, by then, had become a familiar pattern in America's naval diplomacy in Latin American waters: there were highly public displays of U.S. respect for Latin American nations' sovereignty, along with efforts to maximize the visibility of the ships and their crews before the local public. At Buenos Aires and in the Peruvian port of Callao, for example, Kimmel laid wreaths at monuments to national heroes - gestures that, as the U.S. Chargé d'Affaires in Argentina noted, had become "traditional" for U.S. naval crews during the good neighbor years. And during the vessels' four-day anchorage in the Argentine capital, their decks played host to "no fewer than" fifteen thousand local visitors while throngs of others gathered at the pier. ${ }^{61}$

\footnotetext{
${ }^{60}$ Minutes of the Meeting of the Standing Liaison Committee, November 14, 1938, RG 353, Entry 10, Box 1, National Archives.

${ }^{61}$ U.S. Chargé d'Affaires in Buenos Aires to Secretary of State, May 12, 1939, RG 59, File 811.3310/1372, National Archives.
} 
But along with these established elements of good neighbor naval diplomacy appeared other features that betrayed both the depth of the threat that officials within the Roosevelt administration perceived in South America and the sense of urgency they felt about confronting it. During the ships' stay in Argentina, a nation that had proven itself a thorn in the side of Roosevelt's efforts to unify the hemisphere at inter-American meetings in 1936 and 1938, public remarks by U.S. officials stressed the shared history and heritage of the Americas and sought to contrast their history of peaceful, cooperative coexistence with the turbulent international situation prevailing in Europe. The American desire to influence Argentina's hemispheric policy was palpable. Addressing a gathering of Argentine and American officials during the ships' visit to Buenos Aires, U.S. Chargé d'Affaires S. Pinkney Tuck noted that the world had recently witnessed a "collapse of the forces which modern civilization has developed to resolve international problems," and emphasized that, in an increasingly dangerous world, it was important that "no shadow of misunderstanding or suspicion" exist between the American republics. ${ }^{62}$ In Peru, which had been more cooperative with U.S. efforts despite being led by a Europhile President, Oscar Benavides, who was reserved toward the United States, U.S. officials reinforced such rhetoric with gestures designed to underscore the two nations' comparatively deep naval ties. ${ }^{63}$ Their hope was that the bonds between the two nations' navies could help inspire Peruvian officials to make public statements of solidarity with U.S. aims for hemispheric security, and in doing so, help further built inter-American solidarity. On the Division's third day in the port of

\footnotetext{
${ }^{62}$ Remarks of U.S. Chargé d'Affaires, May 9, 1939, enclosure to U.S. Chargé d'Affaires in Buenos Aires to Secretary of State, May 12, 1939, RG 59, File 811.3310/1372, National Archives.

${ }^{63}$ Lawrence Clayton notes that Benavides "was not a fan of the United States, its people, or its institutions. He had spent many years in Europe, especially in France and Italy, in various military and diplomatic missions, and was disposed to favor Germans and Italians equally with Americans in Peru's relations with foreigners." See Clayton, Peru and the United States: The Condor and the Eagle, 160.
} 
Callao, after a full schedule of sporting competitions, receptions, and ceremonies, Admiral Kimmel took the extraordinary step of welcoming President Benavides and a host of highranking officials aboard his flagship, the U.S.S. San Francisco, as the three vessels of the Division embarked for a brief demonstration of "simple maneuvers" at sea. Just beyond the waters of Callao harbor, as the ships demonstrated high-speed movements, their crews launched two aircraft each, which subsequently flew in formation with Peruvian planes in a visual representation of inter-American naval cooperation. The demonstration had the desired effect. During the on-board lunch that followed, Benavides remarked that he saw in the U.S. ships far more than a mere display of raw naval power. Rather, their presence in Peruvian waters represented "the strength of the historic ties of friendship and mutual regard which have always existed between our countries and of moral strength and integrity in a troubled world." ${ }^{, 64}$

While officials in the Roosevelt administration welcomed such sentiments as evidence that Benavides and his government were moving more clearly into the U.S. fold, they were no doubt more encouraged by Peruvian press retrospectives on Cruiser Division Seven's visit. ${ }^{65}$ On June 1st, the day after the American vessels departed for Panama, an editorial in La Cronica concluded that the six days when "the flag of the United States flew in Callao together with the bicolor of Peru" had been far more than "a simple expression of protocol." The visit represented a "sincere and fruitful" renewal of "expressions of fraternal camaraderie and continental solidarity" between the longtime partners at a time when South

\footnotetext{
${ }^{64}$ Commander, Cruiser Division Seven (Kimmel) to Chief of Naval Operations, "Report of Visit of Courtesy of Cruiser Division Seven to Callao, Peru," June 3, 1939, RG 59, File 811.3310/1427, National Archives.

${ }^{65}$ The State Department noted approvingly Kimmel's report that the maneuvers conducted with President Benavides aboard "should have a favorable reaction on the relations of our naval mission with the present administration" and "may, possibly, also tend to weaken the Italian influence over the [Peruvian] air force." Ibid.
} 
American nations had to be guardians of their unity. The friendship between Peru and the United States had been founded more than a century earlier on shared ideals, the paper stated, and would endure as an expression of "true americanism" in the face of gathering danger. ${ }^{66}$ The positive reports flowing from Peru were "typical" of the news flowing into Washington about Cruiser Division Seven's South American tour, reported the State Department's Division of the American Republics. It gave momentum to the Roosevelt administration's efforts, and was entirely satisfactory to the president himself, the architect of the voyage. ${ }^{67}$ The visit of the Seventh Cruiser Division to Peru in May 1939 underscored that nation's value to U.S. naval diplomacy at a critical juncture. Peru had been the test bed for the system of U.S. naval and military advising that Washington was deploying throughout Latin America in an attempt to stiffen hemispheric defense. At the same time, Peruvian shores had long been among the friendliest and oft-visited in the hemisphere for U.S. Navy goodwill cruises. Indeed, Admiral Kimmel noted in his after-action report that there seemed a "casual" attitude and "a tendency to take things for granted" among Peruvian officials during the visit - developments he chalked up to the Peruvians' comfort with a long-term U.S. naval presence in their country. The naval mission had been reestablished after a fiveyear absence, he noted, while American naval vessels had been "no uncommon sight" in

\footnotetext{
66 “Zarpó con destino a Colón la división naval norteamericana q' comanda el Contralmirante Husband E. Kimmel," La Cronica, June 1, 1939 - contained as attachment to U.S. Chargé d'Affaires to Secretary of State, June 3, 1939, RG 59, File 811.3310/1387, National Archives.

${ }^{67}$ On May 25th, Selden Chapin, a State Department staffer of the Standing Liaison Committee of the State, War, and Navy Departments sent a brief memorandum to Laurence Duggan, chief of the Division of the American Republics, suggesting that he draft a letter Sumner Welles could send to President Roosevelt informing him of the "real cordiality" that Cruiser Division Seven had encountered in South America up to that point. He noted that the president would likely be keenly interested "since, as you know, this cruise was undertaken more or less at the President's own personal suggestion." See Chapin to Laurence Duggan, May 25, 1939, RG 59, File 811.3310/1372, National Archives. That letter, sent to Roosevelt on June 10th, forwarded copies of dispatches and press clippings attesting to "spontaneous popular demonstrations of welcome and friendship which greeted the officers and men of the Division and attended the entire stay at each port." See Under Secretary of State Sumner Welles to President Roosevelt, June 10, 1939, RG 59, File 811.3310/1372, National Archives.
} 
Peruvian waters throughout much of the decade. ${ }^{68}$ Such intimate naval ties made the U.S. task of keeping Peru within the inter-American hemispheric defense network considerably easier than it otherwise might have been.

\section{A DEEPENING SECURITY PARTNERSHIP}

Aided in no small measure by both strands of American naval diplomacy, U.S.Peruvian security ties, which had grown tighter as the external threat to the Americas grew in the late 1930s, entered their closest period since the Leguía years with the election of Manuel Ignacio Prado y Ugarteche to the Peruvian presidency in late 1939. Prado, the son of a wealthy, politically active family from the Peruvian aristocracy, proved to be a willing partner who supported U.S. and Allied aims to a degree that Benavides, who had done more to support American aims for hemispheric security than U.S. officials had expected, never entertained. Prado's father had been President of Peru at the outset of the War of the Pacific against Chile, and in the eyes of many Peruvians had tainted his family's name by fleeing the country during that conflict's opening months. His patriotism in question because of his father's actions, the younger Prado had much to prove to his countrymen both as a candidate and as president. He rode the promise of a broad middle-class tax cut to victory over the ineffective José Quesada Larrea in the November elections, and as Daniel Masterson notes, set out to govern as a "conservative modernizer" once in office. In practical terms, that meant Prado would pursue a more intimate economic relationship with the United States, which, for its part, was preparing to significantly expand its Latin American trade in order to capitalize on the inevitable collapse of Latin America's European trade as a result of the war.

\footnotetext{
${ }^{68}$ Commander, Cruiser Division Seven (Kimmel) to Chief of Naval Operations, "Report of Visit of Courtesy of Cruiser Division Seven to Callao, Peru," June 3, 1939, RG 59, File 811.3310/1427, National Archives.
} 
Prado's would be Peru's most pro-American administration since Leguía (19191930), something that was politically possible because of the unique alignment of political forces within the country at the time. Most significantly, the Alianza Popular Revolucionaria Americana (APRA), the leftist party founded in the 1920s in opposition to Leguía's brand of export-led development, and which had fought a pitched battle against the government of President Luis M. Sanchez Cerro in the early 1930s, was no longer staunchly opposed to such cooperation. By the later part of the decade APRA, which had been forced underground in the later years of the Benavides administration, was busily moderating its core ideology in an attempt to regain its lost public standing. Accordingly, Aprista leaders opted not to oppose Prado's candidacy in the 1939 election, as they no doubt would have done under more normal circumstances, in the hope that he would support the party's legalization once in office. ${ }^{69}$ Moreover, in an effort to curry favor in the United States, APRA founder and longtime U.S. critic Víctor Raúl Haya de la Torre had even taken to praising both the Roosevelt administration's Good Neighbor Policy and U.S. aims for hemispheric security. ${ }^{70}$ Such acts would have seemed incomprehensible just a few years before, and represented a sea-change in Peruvian politics. Thus, by the late 1930s APRA no longer enjoyed the prominence it once had as the leading voice of Peru's political left. It also toned down its vocal criticism of Peru's capitalist development, recognizing that the country's improved economic fortunes had done much to undermine such appeals in the eyes of Peru's voting public. As a result, Prado faced no real political threat on his left as the

\footnotetext{
${ }^{69}$ Frederick Pike notes that "In spite of consistent APRA denials, there are indications that before the elections Prado had reached a secret understanding with Apristas: in exchange for their promise to support him or at least not to oppose him at the polls, Prado agreed to legalize their party after coming to power." See Pike, The Modern History of Peru, 276.

${ }^{70}$ Ronald Bruce St. John notes that "Before World War II, Haya had begun to court the US government as well as influential North American citizens to encourage their intervention on APRA'S behalf." See St. John, The Foreign Policy of Peru, 181.
} 
1939 election approached. Nor did he encounter any real opposition from Peru's politicallyminded military establishment. The Army, which had played the decisive role in Leguía's 1930 ouster, had just come through a decade of unprecedented growth and was flush with resources, the product of 1) having an Army man (Benavides) as president for much of the time, and 2) facing a possible ground war with Ecuador. Enjoying the higher profile that came with a 300-percent increase in troop strength, Peruvian Army leaders looked to Prado, Benavides' hand-picked candidate, to keep the good times rolling. ${ }^{71}$ At the same time, the Navy, whose budgets were consistently lean under Benavides, was nevertheless satisfied both with Benavides' embrace of a U.S. naval mission as well as Prado's more enthusiastically pro-U.S. outlook, which optimistic naval officers believed could only portend good things for their institution. ${ }^{72}$

As President, Prado was a stalwart friend of the Allied cause and a staunch supporter of U.S. aims for hemispheric security. It was his administration that concluded the agreement that brought a U.S. aviation to Peru in mid-1940, closing the Italian mission Benavides had favored and opening Peru even further to U.S. military influence. ${ }^{73}$ That same year, the Peruvian Ministry of Foreign Affairs began issuing clear statements, pleasing to Washington, that were supportive of "the unity and general neutrality of the Pan-American system." And, also satisfactory to the Roosevelt administration, at the July 1940 meeting of American republics in Havana, Peruvian representatives signaled the Prado administration's

\footnotetext{
${ }^{71}$ Masterson notes that the Peruvian Army grew from just over 8,000 troops in 1933 to nearly 25,000 by decade's end. See Masterson, The History of Peru, 136.

${ }^{72}$ This summary of Peruvian politics in the late Benavides and early Prado years is based on the work of Daniel Masterson, Jorge Ortiz Sotelo, and Ronald Bruce St. John. See ibid., 135-36. See also Daniel M. and Jorge Ortiz-Sotelo Masterson, "Peru: International Developments and Local Realities," in Latin America During World War II, ed. Thomas M. and John F. Bratzel Leonard (New York: Rowman \& Littlefield, 2007), 131. Finally, see St. John, The Foreign Policy of Peru, 181-82.

${ }^{73}$ U.S. Department of State, "Naval Aviation Mission: Agreement Between the United States of America and Peru, Signed July 31, 1940," Executive Agreement Series, No. 178.
} 
willingness to prohibit the dissemination of potentially damaging "warlike propaganda" within Peru. $^{74}$

Peru's cooperation with Washington under Prado only accelerated after the United States entered the war in late 1941. Peru broke diplomatic relations with the Axis powers in January 1942, only weeks after the Japanese attack on the U.S. Pacific Fleet at Pearl Harbor, Hawaii. ${ }^{75}$ It also cooperated very closely with controversial Roosevelt administration efforts to round up and isolate persons of suspect nationalities (principally Japanese and German) during the war. Between 1942 and 1945 Prado's government arrested and deported nearly two thousand Peruvians of Japanese descent to the United States, where they were held in internment camps for the duration of the war. It was a measure of collaboration that historian Lawrence Clayton calls a "tragic persecution" of a vibrant and ultimately unthreatening minority of the Peruvian population. ${ }^{76}$ It also served as a clear indication of Prado's devotion to the Allied cause.

Prado also put Peruvian resources at the disposal of the United States and the Allied war effort. At his direction, the Peruvian Navy supported U.S. naval units guarding southern approaches to the Panama Canal. In 1942 he cleared the way for the United States to build a new airfield, El Pato, near the northwestern coastal city of Talara, to further assist with Canal security and to provide protection to the nearby Talara oil fields. ${ }^{77}$ Perhaps most significantly, though, Prado ensured that Peru offered steadfast economic support for the Allied war effort. Throughout the war years, Peru maintained steady exports of critical war

\footnotetext{
${ }^{74}$ Carey, Peru and the United States, 1900-1962, 105-06.

${ }^{75}$ Masterson, "Peru: International Developments and Local Realities," 126.

${ }^{76}$ Clayton, Peru and the United States: The Condor and the Eagle, 161.

${ }^{77}$ The airfield at Talara also served to help secure nearby oil fields being serviced by U.S. oil companies. See Carey, Peru and the United States, 1900-1962, 108.
} 
materials to the United States, including rubber, copper, vanadium, petroleum, cotton, and cinchona bark - the last an essential ingredient in the anti-malarial drug quinine needed by U.S. soldiers, sailors, and Marines fighting in the Pacific. ${ }^{78}$ As Jorge Ortiz Sotelo and Daniel Masterson note, although Peru made an indispensible contribution to the Allied war effort by continuing to ship these materials, its cooperation came at a significant cost. Under Prado's leadership the Peruvian economy, which like most Latin American economies was wellpositioned to parlay intensified wartime exchange with the United States into a sustained industrial and commercial boom, failed to implement a "coherent development strategy" and ended up becoming more dependent on U.S. assistance and foreign direct investment than ever before. A sustainable development strategy could have taken shape, they argue, had Peru been successful - as other Latin American countries during the war were - in accumulating a substantial base of foreign exchange reserves. However, in his effort to lend the greatest possible assistance to the Allied war effort, Prado made the fateful decision to maintain price controls on the war-critical raw materials Peru sent to the United States. As a result, Peru's foreign exchange reserves grew at a rate of only 55-percent during the war - far less than countries such as Brazil (635-percent), Colombia (540-percent), and Mexico (480percent), all of which let prices keep pace with market rates and whose economies derived greater long-term benefit from their wartime cooperation. ${ }^{79}$ In short, perhaps more than any other Latin American country, Peru embodied the ideal of wartime good neighborism envisaged by the Roosevelt administration. ${ }^{80}$ It offered unflinching support for Washington's

\footnotetext{
${ }^{78}$ Clayton, Peru and the United States: The Condor and the Eagle, 161.

${ }^{79}$ Masterson, "Peru: International Developments and Local Realities," 127.

${ }^{80}$ In making this point, I embrace the argument of Donald Dozer, who maintains that in the late 1930s, as the Roosevelt administration became increasingly preoccupied with hemispheric defense and inter-American unity, the philosophy underlying the Good Neighbor Policy changed from one of "live and let live" to one of "live and help live." The result, he argues, was that during those years "the nation which called itself the Good Neighbor
} 
aims before the United States became a belligerent, and only intensified that support afterward - at considerable cost to its own longer-term economic well-being.

It is important to note, however, that as one-sided as the wartime economic relationship between the United States and Peru ultimately turned out to be, Peru was successful in leveraging its broader relationship with Washington to secure other vital interests. The Prado administration succeeded, for example, in securing more than $\$ 18$ million in U.S. military assistance under the 1941 Lend-Lease Act. That assistance made the construction of the El Pato air base possible, and enabled to Peru to acquire a small number of military aircraft. It was but a small share of the total amount of Lend-Lease aid the United States distributed to Latin American countries at approximately four percent, and certainly was not as much as Peruvians desired, but it did provide the Peru's armed forces with a noticeable boost in strength. ${ }^{81}$

More significantly, Peru was able to leverage its relationship with the United States to effect a favorable settlement of its long-simmering border dispute with Ecuador. The dispute had been especially heated dispute since Peruvian delegates walked out of U.S.-brokered negotiations in Washington in September 1938. Emboldened by a military buildup undertaken by President Benavides and continued under Prado, Peruvian Army authorities made two critical strategic calculations in June 1941 aimed at resolving the longstanding stalemate. First, as historian Robert Scheina notes, they determined that with the German Army penetrating deeply into the Soviet Union and with the Roosevelt administration undertaking a crash rearmament program to prepare the United States for war, Washington

now eagerly sought to become a Good Partner to the rest of the American nations and to enlist them also as partners in a common cause." See Dozer, Are We Good Neighbors?, 115.

${ }^{81}$ Child, Unequal Alliance: The Inter-American Military System, 1938-1978, 48, 62. 
would view the outbreak of any war in the Americas in 1941 as an "unwelcome distraction" and would do everything possible to settle it as quickly. Accordingly, the Peruvian General Staff, confident of Peruvian Army's superiority over Ecuador, devised a plan to rapidly invade, occupy, and hold the disputed areas of the frontier until Washington, desperate to put an end to inter-American discord, swooped in to facilitate negotiations that confirmed Peru's gains. Peruvian Army units in the contested border regions went on alert in June 1941 after American mediation efforts broke down entirely.

It was at this point that General Eloy Ureta, the Peruvian Army commander in the region, made a second critical strategic calculation: he bet that President Prado, who up until that point had taken a firm but solidly diplomatic approach to resolving the crisis, would be politically unable to stop the Army from taking military action given that his family name was still tainted by his father's actions during the War of the Pacific. The president could not risk further sullying his family name by disavowing a military operation against Ecuador once it was underway, Army leaders concluded. Their calculations were correct. General Ureta ignored President Prado's order that on-alert Army forces stand fast and avoid offensive action, and in late June informed the commander-in-chief that he would imminently be ordering units under his command to attack. On July 5th the Peruvian assault went forward on two fronts - in a small disputed area near the Pacific coast and in a much larger area in the eastern interior. Militarily, it was a rout for Peruvian forces. The smaller, poorly equipped and ill-prepared Ecuadorian forces were no match for Peruvian ground units that had benefitted from years of favorable budgets and an influx of modern equipment. The military campaign was over in a matter of weeks. By mid-August, for all intents and purposes, the Ecuadorian Army ceased to exist as a viable field army. Under intense 
international pressure to halt the fighting, in October the two governments agreed on terms for a ceasefire. Peruvian Army units halted active combat operations and became an army of occupation in the disputed areas. For the Peruvian Army and the Prado administration, the wait for Washington's diplomatic validation began. ${ }^{82}$

As Peruvian Army leaders had suspected they would, Peru's territorial gains received quick validation. The settlement was accelerated considerably by the Japanese attack on Pearl Harbor on December 7th, which raised the stakes for the United States and filled the Roosevelt administration with a new resolve to forge anti-Axis unity in the Americas. A settlement of the Peru-Ecuador dispute, the only ongoing international conflict in the hemisphere, thus became an even more urgent matter than before. It was a major concern of inter-American delegates who gathered at an emergency meeting in Rio de Janeiro in January 1942 to address hemispheric security challenges stemming from U.S. involvement in the war. The meeting fell short of expectations in some respects, as Argentina and Chile, coastal nations that had longstanding ties with Germany and feared the prospect of military invasion, refused to break relations with the Axis nations. But agreement proved easier to achieve on the issue of making peace between Peru and Ecuador. Encouraged by the U.S. representative, Under Secretary of State Sumner Welles, and by the foreign ministers of Brazil, Argentina, and Chile, Peruvian delegate Alfredo Solf y Muro and Ecuadorian representative Julio Tobar Donoso signed a Protocol of Peace, Friendship and Limits on the conference's last day. The agreement broadly affirmed Peru's complete military success and upheld Lima's claims to most of the disputed areas. As a result, the territorial area of

\footnotetext{
${ }^{82}$ This summary of Peruvian strategic calculations and the military situation between Peru and Ecuador is based on accounts by Robert Scheina, Jorge Ortiz Sotelo, and Daniel Masterson. See Scheina, Latin America's Wars: The Age of the Professional Soldier, 1900-2001, 114-21. See also Masterson, "Peru: International Developments and Local Realities," 129-32.
} 
Ecuador was reduced by nearly one-half. Included in the lost territory were tributaries of the Marañón River, which had given Ecuador access to the Amazon River and a means of accessing the Atlantic Ocean. In that sense, Ecuador was a transcontinental nation no more. Given the highly charged diplomatic environment, however, there was little the Ecuadorian government - although bitterly disappointed - could do to resist. For the United States, the overarching imperative was ensuring the peace and unity in the Americas. Peru had proven itself a willing partner in that pursuit, and had demonstrated an ability to leverage U.S. concerns on behalf of its own interests. The quick settlement of the boundary question on terms highly favorable to Peru underscores just how far the U.S.-Peruvian relationship had come since the difficult years just after the fall of Leguía. As Lawrence Clayton concludes, it stands as a testament to the depth of friendship between the United States and Peru during the Prado administration. ${ }^{83}$

\section{CONCLUSION}

For the United States, the close cooperation Peru provided before and during World War II served as an example of what was possible in inter-American relations, and helped facilitate broader inter-American collaboration in hemispheric security. During World War II, few Latin American nations had stronger, more cordial diplomatic ties with the United States than did Peru. Although its significance to U.S. military designs for hemispheric defense lagged behind that of nations like Colombia and Brazil, Peru's history of close, cooperative naval relations with the United States recommended it to the Roosevelt

\footnotetext{
${ }^{83}$ For Clayton's conclusion, see Clayton, Peru and the United States: The Condor and the Eagle, 150. This treatment of the Rio meeting is based on accounts by Robert Scheina, Jorge Ortiz Sotelo and Daniel Masterson, and Ronald Bruce St. John. See Scheina, Latin America's Wars: The Age of the Professional Soldier, 19002001, 122. See also Masterson, "Peru: International Developments and Local Realities," 132. See also St. John, The Foreign Policy of Peru, 182.
} 
administration as a useful partner and ally in securing the Western Hemisphere from external threat. The close relationship that the U.S. and Peruvian navies had developed during the 1920s and early 1930s served as a foundation for the strong bilateral ties that bound the United States and Peru during the World War II years. Moreover, it helped pave the way for broader naval and military cooperation that has characterized inter-American relations ever since. Although the substantive accomplishments of the U.S. naval mission sent to Peru in 1938 were comparatively modest in real terms, its presence served an important political purpose, and helped anchor that productive wartime relationship. At the same time, goodwill visits by U.S. Navy vessels to Peruvian waters gave that cooperation a highly visible public dimension. Together, both threads of U.S. naval diplomacy served as a springboard for broader inter-American military cooperation during the war years. 


\section{CONCLUSION}

Peru offered staunch support to the United States and the Allies even after its territorial gains from Ecuador were confirmed at the January 1942 meeting of American Republics at Rio de Janeiro. Throughout World War II, Peru continued to export critical raw materials to the United States at below-market prices. The Peruvian and U.S. navies jointly patrolled the waters of the southeast Pacific Ocean. And the administration of Peruvian President Manuel Prado carried on arresting and detaining persons of Japanese descent well into 1945. In all respects, Peru was a stalwart ally of the United States, cooperating in strategic, economic, and diplomatic matters in equal measure. ${ }^{1}$ Although relations between the two nations had been cordial and generally cooperative before 1919 , it is hard to imagine Peru offering such strong support to the United States and the Allied war effort during World War II in the absence of the interwar developments that drew the two nations together. The most important of those developments, this dissertation contends, took place in the realm of naval affairs.

In the early 1920s, the naval relationship the United States developed with Peru enabled it to integrate the Andean nation into its expanding empire. The key development in this regard was the sending of the U.S. naval mission to Peru in 1920, which gave Washington a substantial degree of strategic and economic influence within that country at a time when political conditions, both within the United States abroad, made the use of armed intervention in South America unthinkable. At the invitation of Peruvian President Augusto

\footnotetext{
${ }^{1}$ Daniel Masterson and Jorge Ortiz Sotelo conclude that Peru was "one of the most ardent supporters of the Allied cause" throughout World War II, and that it "cooperated fully with the United States, economically, commercially, and diplomatically." See Masterson, "Peru: International Developments and Local Realities," 141.
} 
Leguía, naval mission members assumed positions of formal command within the Peruvian Navy, and quickly became key members of the president's inner circle. Their extraordinary access to the center of power gave U.S. foreign policymakers and naval leaders in Washington a tool with which to advance American interests in Peru and in the region. U.S. Navy leaders, for example, saw the mission's efforts to develop Peruvian naval education as a long-term good, believing that American security interests would be well served by having compatible, like-minded naval establishments in as many Latin American countries as possible. This is visible also in the mission's work to establish a modern submarine force as the cornerstone of the Peruvian fleet. At the same time, U.S. diplomats looked favorably on mission members' efforts to develop a national aviation system in Peru, believing that that nation's need for foreign expertise in flight would create a valuable opening for American aviation concerns to enter the lucrative South American market. All the while, both foreign policymakers and businessmen viewed the U.S. naval mission as a stabilizing influence in Peru. The remarkable political stability that prevailed under Leguía, with the assistance of the U.S. naval mission, increased the confidence of American investors, who in turn showered that country with more than $\$ 100$ million in loans - infusions of capital that, although they increased Peru's indebtedness, fostered economic growth that further solidified Leguía's grip on power. By the late 1920s, the United States maintained no closer, more cordial relations with any nation in Latin America than it did with Leguía's Peru. The U.S. naval mission was integral to the development of that relationship, and helped pave the way for Peru's integration into the American empire in the Western Hemisphere.

It is important to stress that, in casting the U.S. relationship with Peru during the interwar period in imperial terms, this dissertation is not suggesting that Peru stood passively 
by as the United States dictated the course of the bilateral relationship. Rather, it recognizes that Peruvian leaders retained a significant degree of agency in the relationship, and exercised considerable control over their nation's relations with the United States. In no aspect of the bilateral relationship was this more apparent than in naval affairs. In the 1920s, for example, President Leguía proved quite adept at pushing American foreign policymakers further than they wished to go in lending support to his naval designs. He pushed the United States to sell Peru modern naval hardware (especially submarines) early and often in his presidency. When he ran into opposition, Leguía resorted to manipulating the American bureaucracy, playing Navy and State Department leaders against one another to create openings through which he could achieve his objectives. And, as in the case of the Woodward imbroglio of late 1923, the dictator used the naval mission's executive authority over the Peruvian Navy to give his designs the appearance of American approval.

Throughout his reign, Leguía strengthened his hand by using flattery and public professions of fondness for American values to ingratiate himself to Washington. For example, he declared the Fourth of July a Peruvian national holiday, and hung a large portrait of U.S. President James Monroe - father of the "Monroe Doctrine," the cornerstone of U.S. hemispheric policy since the 1820 s - in the presidential palace. ${ }^{2}$ Moreover, rarely did Leguía or his representatives speak publicly of the United States without referring to it as the "Great Republic of the North." ${ }^{3}$ Over time, moves such as these caused U.S. foreign policymakers

\footnotetext{
${ }^{2}$ One of the many examples of this type of flattery that is worth noting came in an August, 1922 speech in which Leguía declared "Our respect and admiration for the United States of America were once more evidenced unmistakably by the inauguration of the monument that my Government in response to national sentiment dedicated on the $4^{\text {th }}$ of July to the Founder of the Great Republic of the North, the immortal George Washington.” See Report on General Conditions Prevailing in Peru During the Previous Month, August 8, 1922, RG 59, File 823.00/423, National Archives.

${ }^{3}$ One of many examples of this comes from 1926, when, in lauding U.S. foreign policy in the hemisphere, $\mathrm{La}$ Prensa, the state-controlled newspaper Leguía seized in the early 1920s, declared that "The Great Republic of
} 
to see Leguía as an enlightened leader worthy of their nation's full support. Each adoring superlative Leguía lobbed at the United States reinforced American diplomats' deep-seated belief (conditioned by racial attitudes) that the mestizo Leguía was uniquely suited to lead the heavily indigenous, "ignorant” nation to a brighter, more prosperous future. ${ }^{4}$ Leguía’s highly public, freely expressed admiration for the United States had the desired effect. U.S. support for his government grew consistently stronger throughout the 1920s, and by the end of the decade, Washington was deeply invested in his rule.

Another way Peruvian leaders throughout the interwar period exercised control over their relationship with the United States was by playing on U.S. fears of European encroachment in South America. Leguía, for one, employed this tactic again and again first, to secure a U.S. naval mission in 1920, and later, in an attempt wither U.S. resistance to the idea of sending his government a mission of Army officers to complement the work of the naval mission. As proficient as he was in deploying the boogeyman of European meddling to get what he wanted from Washington, however, Leguía's accomplishments in this regard were surpassed by those of President Oscar Benavides (1933-1939), whose Europhilic tendencies gave American foreign policymakers fits in the late 1930s. In late 1937 Benavides' government dangled the prospect of accepting a British naval mission in order to press ongoing naval mission negotiations with Washington toward a productive end. To U.S. officials preoccupied with inter-American solidarity and hemispheric security, the prospect of Europeans (even the British) gaining sway over a Latin American military establishment was unacceptable. The move had the effect the Peruvians desired, as the U.S.

the North never yet fired a single cannon shot in South America." See Report on General Conditions Prevailing in Peru During the Previous Month, August 21, 1926, RG 59, File 823.00, National Archives.

${ }^{4}$ As noted earlier in this work, see U.S. Chargé d'Affaires in Peru to Secretary of State (Confidential), November 29, 1921, RG 84, Vol. 182, National Archives. 
State Department moved quickly to close the deal and dispatch a new naval mission to Lima. In another shrewd, well-timed move, at almost the same moment Benavides contracted with the Mussolini government of Italy for a mission of aviation officers to advise the Peruvian Navy and Army. Coming on the heels of the successful naval mission negotiations, this put the Roosevelt administration on edge. The net effect was that from late 1937 until it ultimately succeeded in securing an agreement in 1940, the United States made sending a U.S. naval aviation mission to Peru to displace the Italian one a priority of its policy toward Peru.

Also visible in the naval dimensions of the U.S.-Peruvian relationship in the interwar period is a clear divergence, persistent in U.S. foreign policy, between professed ideals and actions. In the years immediately following World War I, the United States under President Woodrow Wilson championed the principles of democracy and national self-determination in the world, and led international efforts to build a new, permanently peaceful global order. If American policy at the time had been consistent with the Wilson administration's highminded progressive rhetoric, U.S. relations with Peru would certainly have proceeded along a far different track in the 1920s. As it stood, though, postwar U.S. policy toward Peru, and Latin America more broadly, turned on traditional strategic and economic concerns. A strong desire to prevent European nations from reasserting their dominant influence over South American military and naval establishments helped drive the Wilson administration's favorable response to Leguía's request for a U.S. naval mission. Meanwhile, the keen interest of American business in exploiting Peru's rich natural resources led U.S. foreign policymakers to quickly embrace Leguía’s open invitation for American investment in Peru. Together, the prevalence of strategic and economic concerns left little room for progressive 
idealism in Washington's approach to Peru. ${ }^{5}$ To U.S. foreign policymakers, Augusto Leguía was the kind of leader who could protect and promote tangible American interests. As a result, U.S. foreign policymakers in administrations from Wilson through Herbert Hoover saw Leguía's growing authoritarianism, and the stability it provided, as a net positive for American interests.

The U.S. naval mission served as a guarantor of that prized stability. It gave Leguía a measure of security from his domestic political foes. It helped strengthen the Peruvian Navy, Leguía's favored branch of national military power, and enabled it to serve as counterweight to the politically active Peruvian Army, of which the dictator was wary. Without a doubt, the U.S. naval mission aided Leguía in fashioning a stable, orderly, and repressive dictatorship. More broadly it was a vital part of the large, direct, and ongoing support that the United States extended to Leguía's government for more than a decade. And in that sense, the U.S. naval mission to Peru was an integral player making the 1920s a watershed period in U.S.Latin American relations: it was the first time the United States went to great lengths to strengthen a Latin American dictator's hold on power. Today, the history of U.S. support for dictatorships in Latin America is well known. Most contemporary studies trace its origins either to the Cold War or to the non-interventionist Good Neighbor Policy pursued by the Franklin D. Roosevelt administration - a period when the United States embraced Latin American strongmen as a way of maintaining regional order without having to wield the threat of intervention. But in examining the naval dimensions of U.S.-Peruvian relations during the 1920s, its true origins come more clearly into focus. In its dealings with Leguía, the United States exposed itself as a nation willing to depart from its ideal of promoting

\footnotetext{
${ }^{5}$ See Tulchin, The Aftermath of War: World War I and U.S. Policy Toward Latin America.
} 
democracy and self-determination abroad when national interests could best be served, at least in the short term, by embracing stable, non-democratic regimes.

The gulf between ideals and actions in U.S. policy toward Peru is visible in the postLeguía years, as well. In the late 1930s, as U.S. relations with Latin America became dominated by hemispheric security concerns, foreign policymakers in the Roosevelt administration redoubled their efforts to burnish the good neighbor image of the United States throughout Latin America. Driving this effort was the belief that, whether or not they were capable of contributing to a military defense of the hemisphere, all Latin American nations had important roles to play in resisting both armed attacks and possible subversive efforts mounted by external powers. Courting the maximum degree of cooperation, U.S. officials used public statements to emphasize the common heritage of the Americas, North, South, and Central: their experience throwing off European colonialism, their mutual embrace of democratic institutions and republican government, and their shared belief in the superiority of the "new world" over the old. ${ }^{6}$ Accordingly, U.S. naval and military assistance to Latin American nations before and during World War II was billed publicly as an effort to help improve their ability to make substantive contributions to the defense of shared American ideals. Behind the scenes, however, it was a different story. As this dissertation's examination of the reestablished naval mission to Peru demonstrates, in Peru as throughout much of Latin America, U.S. military assistance served the fundamentally diplomatic purpose of keeping up appearances. ${ }^{7}$ With the exceptions of Brazil, Colombia, and Mexico,

\footnotetext{
${ }^{6}$ David Rock, "War and Postwar Intersections: Latin America and the United States," in Latin America in the 1940s: War and Postwar Transitions, ed. David Rock (Berkeley: University of California Press, 1994), 19-20.

${ }^{7}$ Brazil and Mexico eventually contributed troops to Allied military efforts in Europe, and were the two largest recipients of U.S. military assistance under the Lend-Lease Act. In State Department correspondence from the late 1930s, Colombia, because of its geographic location vis-à-vis the Panama Canal and its naval capabilities,
} 
each of which was viewed as capable of making a significant military contribution to hemispheric defense, the priority of such assistance to Latin American nations was visibility. It was important that the United States be seen as helping to provide for Latin America's defense needs. Less important was whether that assistance was significant in scope, or whether it contributed materially to actual improvements in Latin American nations' defense capabilities.

Finally, the naval relationship the United States forged with Peru during the interwar period demonstrates the centrality of non-coercive naval power to U.S.-Latin American relations. The U.S. naval missions to Peru, first in the 1920s and later from 1938 into the World War II years, represented a clear break from the gunboat diplomacy that had characterized U.S. naval involvement in Latin America in the early twentieth century. Both were of fundamental importance to the course of U.S.-Peruvian relations during challenging times. For all the problems and challenges that flowed from the Leguía-era naval mission, its achievements laid the foundation for a close, enduring naval relationship between the two countries. Moreover, in the longer-term, the naval mission's work demonstrated that interAmerican cooperation in the naval-military realm could achieve significant results. In that sense the U.S. naval mission to Peru stands out as the forerunner to the extensive network of naval and military advisers that the United States has maintained throughout Latin America ever since World War II. Today, these advisory groups remain a cornerstone of interAmerican military cooperation, and of U.S. foreign policy in the region more generally. Naval power has remained a central feature of U.S. policy toward Latin America in another key respect, as well: since the Hoover and Roosevelt administrations first embraced 
it as an instrument of policy during the interwar period, the United States has continued to employ naval cruises for the purposes of directly reaching and convincing Latin American peoples of its good neighbor intentions. That is, goodwill naval cruises have continued to play a key role in U.S. public diplomacy in the Western Hemisphere. Prior to Hoover's preinaugural goodwill tour of Latin America in late 1928 and early 1929, U.S. naval vessels and personnel had been agents of a long-term policy of armed interventionism which was reviled throughout Latin America and increasingly unpopular at home. Following Hoover's journey through Central and South American waters, changes in U.S. naval policy reflected the importance that U.S. diplomats and naval leaders began attaching to foreign goodwill cruises. Such cruises, they increasingly thought, could help substantially improve U.S.-Latin American relations. Indeed, changing the U.S. approach to Latin America was one of the few things on which Hoover and his successor, Roosevelt, could agree. ${ }^{8}$ Despite their myriad differences in other areas, both saw value in using the Navy to facilitate real change.

Upon assuming office, Roosevelt, who had served as Assistant Secretary of the Navy during the Woodrow Wilson administration, took a personal interest in employing the Navy as the face of good neighborism in Latin America. After some early successes, most notably the 1934 shakedown cruise of the U.S.S. Ranger, Roosevelt dispatched active elements of the U.S. Fleet on public diplomacy missions aimed at fostering goodwill. These missions consistently featured activities intended to demonstrate a neighborly respect for the sovereignty of Latin American nations, maximize the direct contact local populations had with U.S. ships and naval personnel, and showcase the technological advancement and strength of the United States. The high-profile goodwill cruises the Navy made to Peru in

\footnotetext{
${ }^{8}$ DeConde, Herbert Hoover's Latin-American Policy. See also Wood, The Making of the Good Neighbor Policy. See also Pike, FDR's Good Neighbor Policy: Sixty Years of Generally Gentle Chaos.
} 
1936, 1937, and 1939 were particularly influential in helping to repair bilateral relations that had been troubled since the overthrow of the U.S.-backed Leguía dictatorship. They confirmed to key officials in the Roosevelt State Department, especially Under Secretary of State Sumner Welles, that the Navy had an integral, ongoing role to play in the nation's public diplomacy. Goodwill naval cruises helped clearly align Peru and much of Latin America with U.S. designs for hemispheric defense. And more broadly, they became key components of U.S. public diplomacy in the Western Hemisphere in the longer term. Today, more than seventy years later, ships of the U.S. Navy routinely cruise in Latin American waters. Most often, as in the cases of the hospital ship USNS Comfort's regular visits to Latin America and the U.S. Navy's participation in the annual inter-American UNITAS naval exercise, their itineraries are packed with public diplomacy activities. ${ }^{9}$ That naval cruises have continued to play important roles in U.S. public diplomacy in Latin America further underscores the importance of the changes that took place during the interwar period.

\footnotetext{
${ }^{9}$ For example, see "Grapple Crew Participates in Perry Memorial Gateway Rededication Ceremony [Trinidad and Tobago]," U.S. Navy story \#NNS120405-24, accessed April 8, 2012, http://www.navy.mil/submit/display.asp?story id=66332. See also "Underwood Crew Commemorates Chilean Naval Hero," U.S. Navy story \#NNS120608-13, accessed June 10, 2012,

http://www.navy.mil/submit/display.asp?story id=67707. See also Terri M. Cronk, "USNS Comfort Completes Humanitarian Mission,” Armed Forces Press Service, accessed September 17, 2011, http://www.defense.gov/News/NewsArticle.aspx?ID=65236.
} 


\section{APPENDIX 1: PHOTOS}

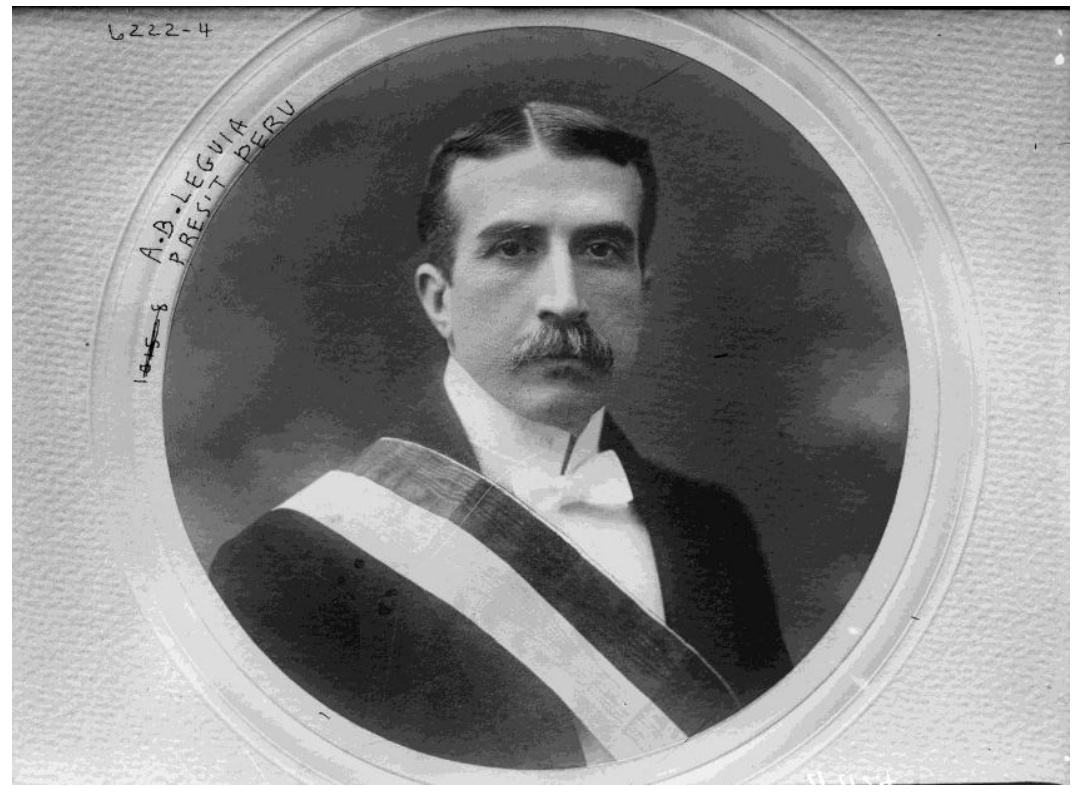

PHOTO 1: Augusto B. Leguía y Salcedo, President of Peru, 1908-1912, 1919-1930.

Source: Library of Congress

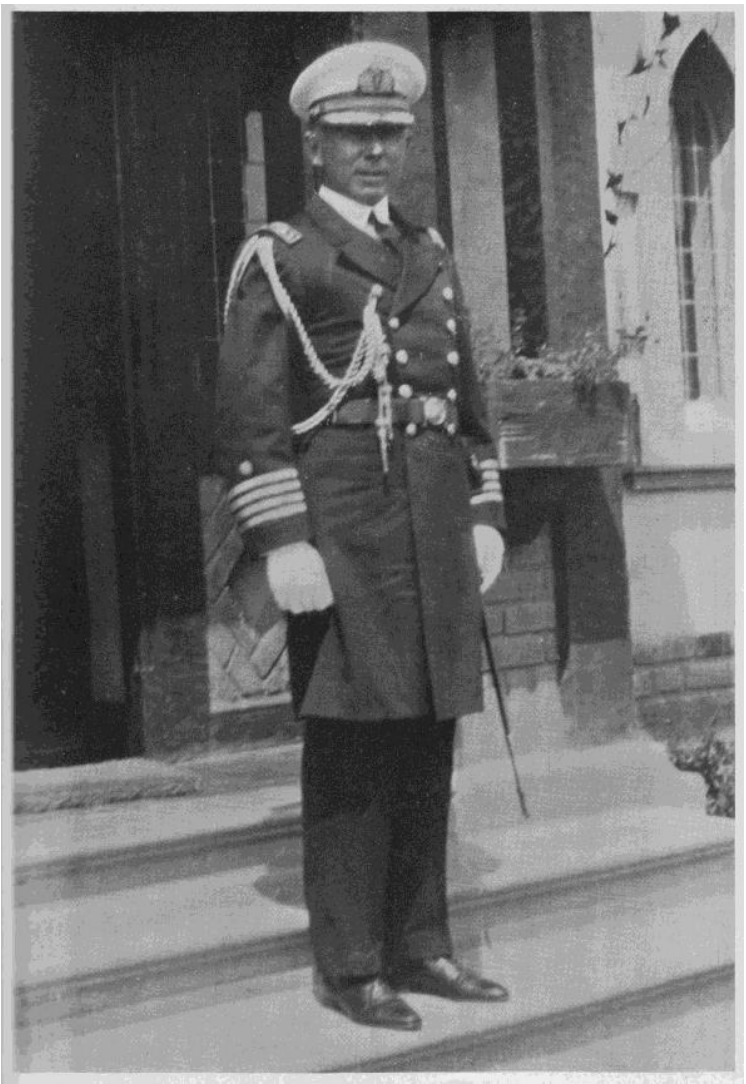

PHOTO 2: William O. Spears (Captain, U.S. Navy) in Peruvian Naval Uniform, 1930.

Source: U.S. Naval Academy 


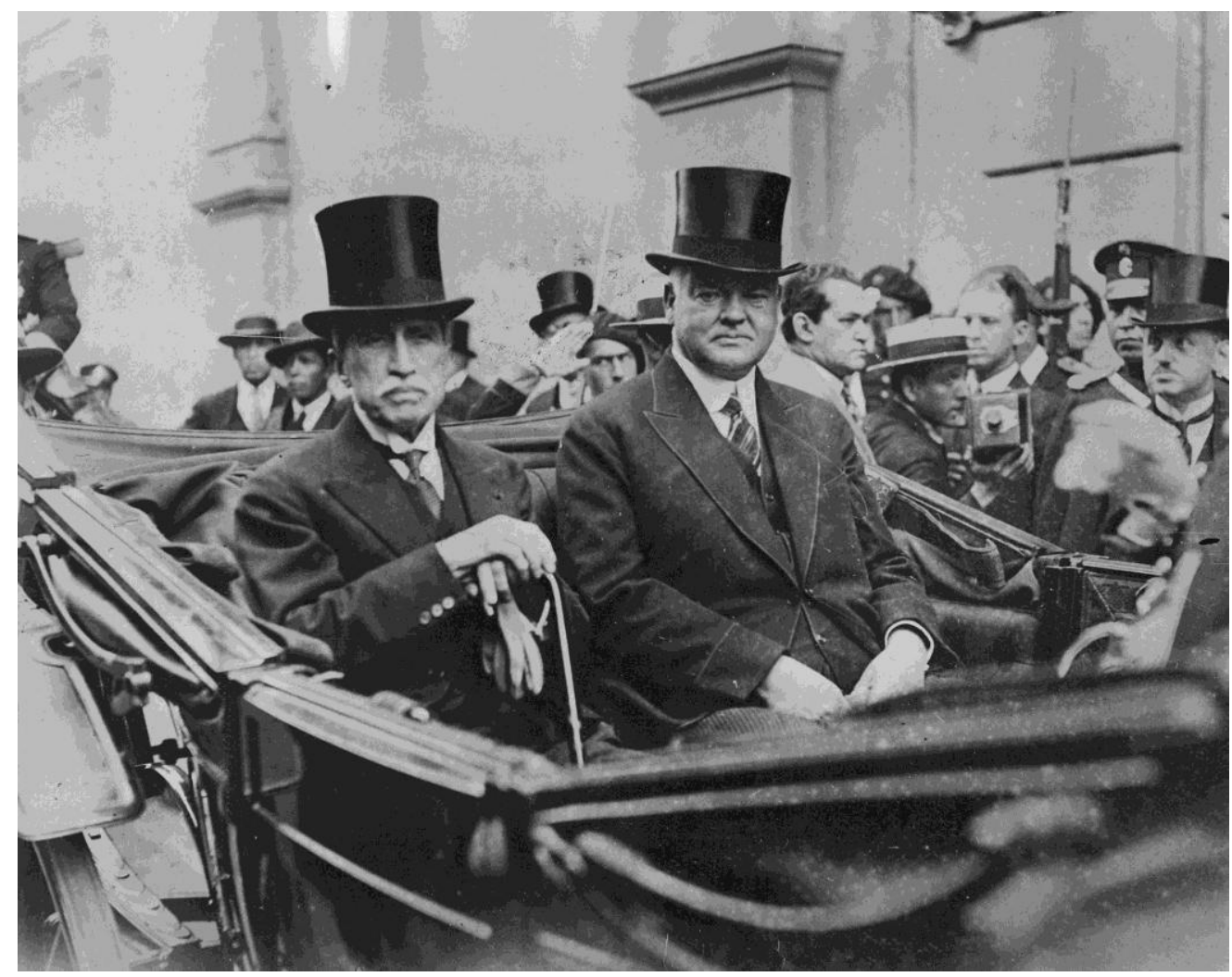

PHOTO 3: U.S. President-Elect Herbert Hoover with Peruvian President Augusto Leguía in Lima, 1928. Source: Herbert Hoover Presidential Library and Museum

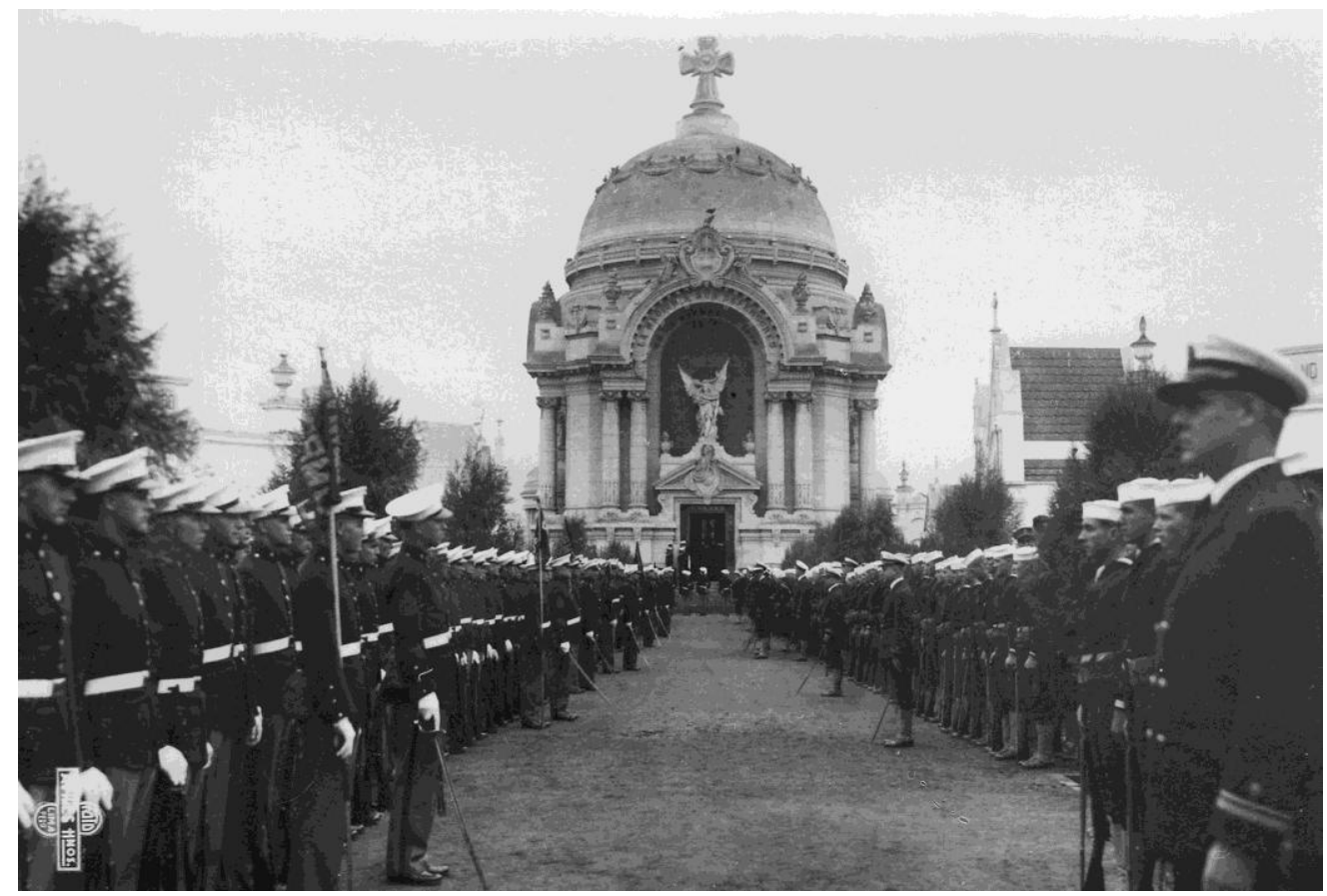

PHOTO 4: U.S. Sailors and Marines render honors at the tomb of Peruvian Almirante Miguel Grau Seminario, 1936. Source: National Archives 


\section{APPENDIX 2: MAPS}

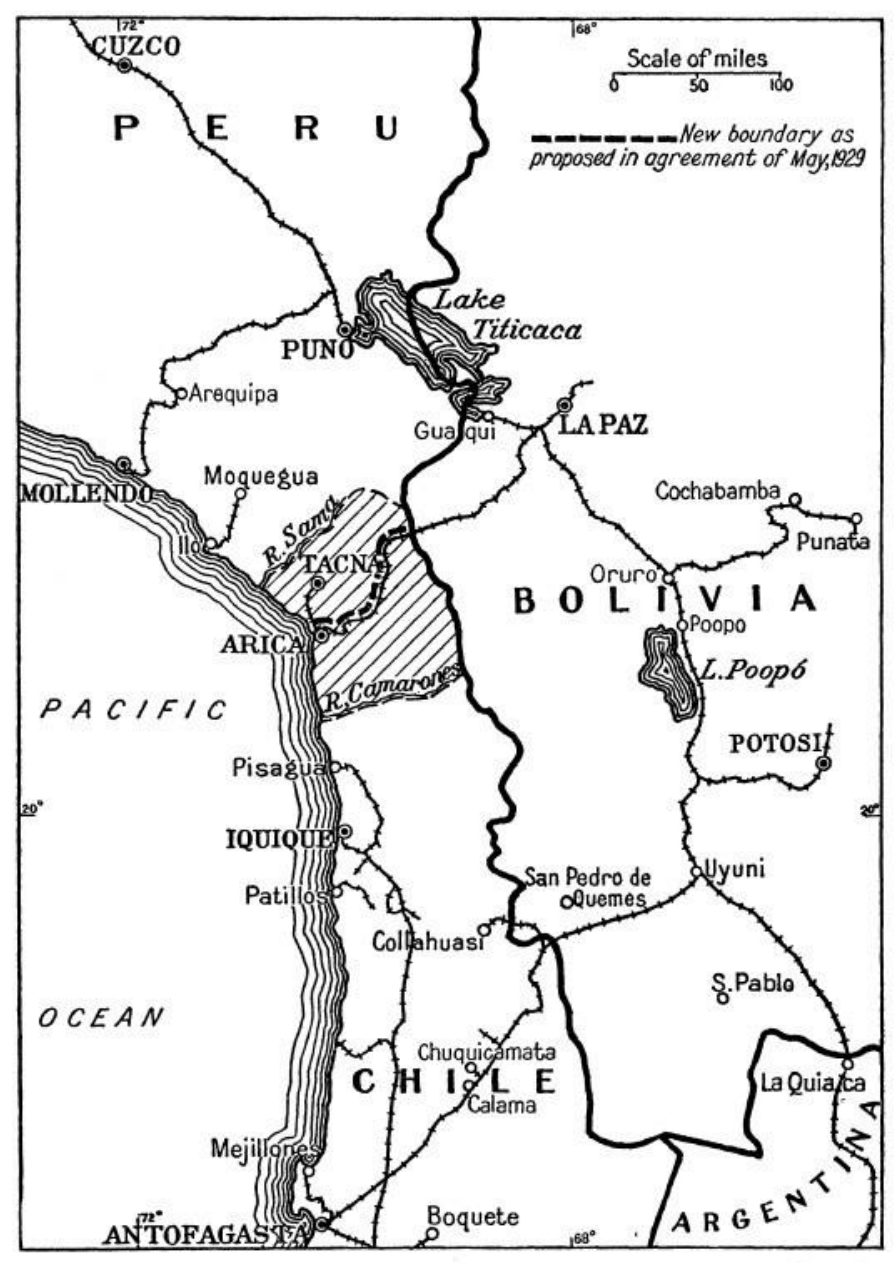

MAP 1: Map depicting the 1929 settlement of the Tacna-Arica dispute stemming from the War of the Pacific. Source: Foreign Affairs 


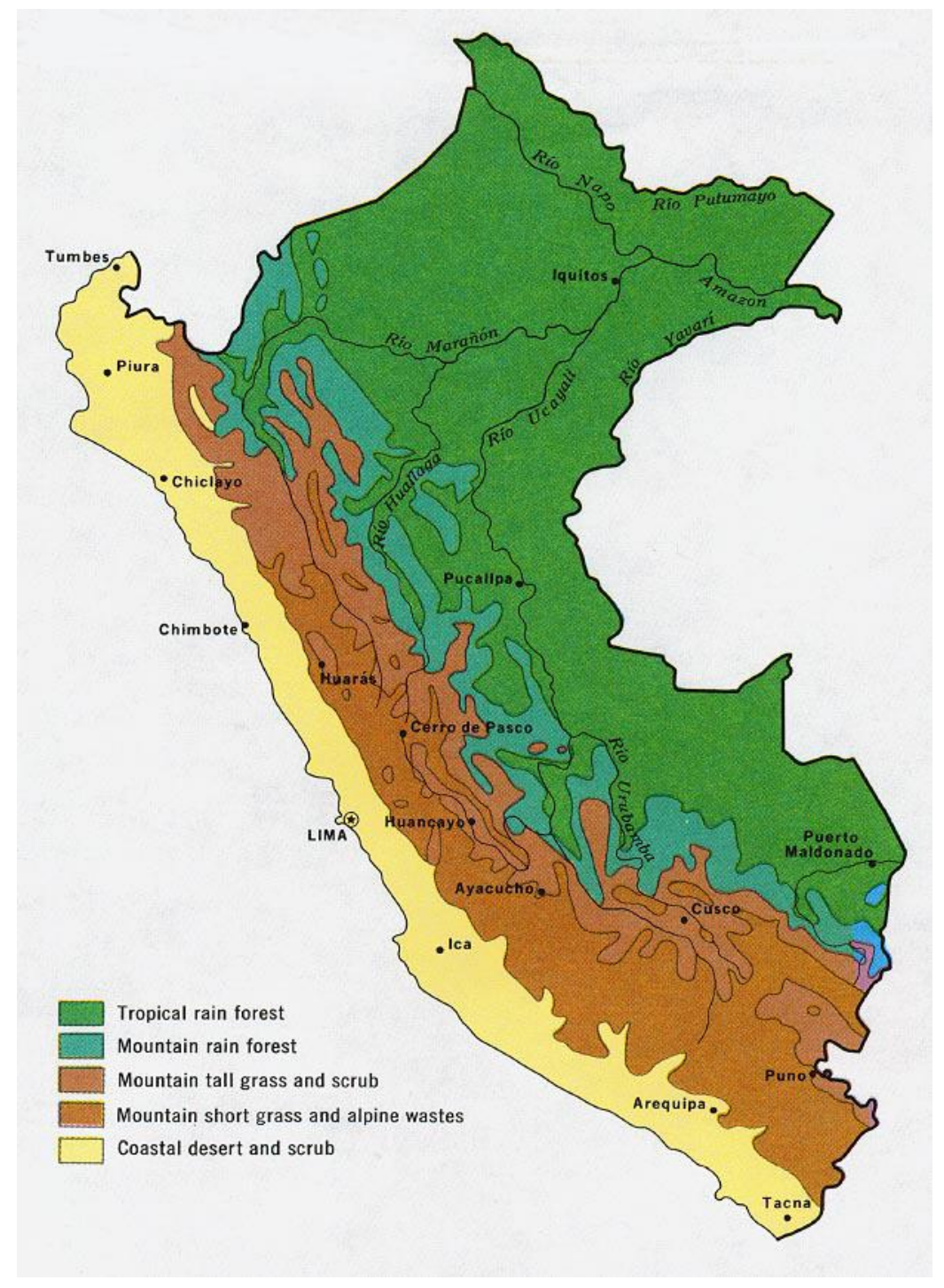

MAP 2: Map of Peru depicting its distinct regions: the costa (coastal desert), sierra (mountains), and selva (rainforest). Source: Perry-Castañeda Library Map Collection, University of Texas 


\section{BIBLIOGRAPHY:}

\section{Manuscript Sources:}

Herbert Hoover Presidential Library, West Branch, Iowa:

President's Personal File

Campaign and Transition File

Lou Henry Hoover Papers

Francis White Papers

National Archives, Washington, DC:

Record Group 38, "Records of the Office of the Chief of Naval Operations"

Record Group 45, "Records of the Office of Naval Records and Library"

Record Group 80, "General Records of the Department of the Navy"

National Archives, College Park, MD:

Record Group 59, "General Records of the Department of State"

Record Group 84, "Post Files of the Department of State"

Record Group 353, "Records of Interdepartmental and Intradepartmental

Committees"

Franklin D. Roosevelt Presidential Library, Hyde Park, New York:

President's Secretary's File

Sumner Welles Papers

FDR Official File

University of North Carolina Libraries (Southern History Collection), Chapel Hill, North Carolina:

William Oscar Spears Papers

\section{Government Publications:}

Aubry, Luis. El Torpedero Submarino y la Reciente Guerra Mundial. Washington: National Publishing Co., 1920.

U.S. Senate. "Munitions Industry: Hearings before the Special Committee Investigating the Munitions Industry, United States Senate, Seventy-Third Congress, Pursuant to S. Res. 206, a Resolution to Make Certain Investigations Concerning the Manufacture and Sale of Arms and Other War Munitions, 1934." Washington, DC: U.S. Government Printing Office, 1935. Marina de la Guerra del Peru. Revista de Marina. Lima, Peru. 
National Archives and Records Administration. "Public Papers of the Presidents of the United States: Herbert Hoover." Washington, DC: U.S. Government Printing Office, 1974.

U.S. Department of State. Foreign Relations of the United States, 1919. 2 vols. Washington, DC: U.S. Government Printing Office, 1934.

U.S. Department of State. Foreign Relations of the United States, 1920. 3 vols. Washington, DC: U.S. Government Printing Office, 1935.

\section{Books:}

Albion, Robert Greenhalgh, and Rowena Reed. Makers of Naval Policy, 1798-1947. Annapolis: Naval Institute Press, 1980.

Baer, George W. One Hundred Years of Sea Power: The U.S. Navy, 1890-1990. Stanford: Stanford University Press, 1994.

Basadre, Jorge. Historia De La República Del Perú, 1822-1933. 6. ed. 17 vols. Vol. 14, Lima: Editorial Universitaria, 1968.

—. Historia De La República Del Perú, 1822-1933. 6 ed. 17 vols. Vol. 13, Lima: Editorial Universitaria, 1968.

Bell, P. M. H. The Origins of the Second World War in Europe. Origins of Modern Wars. London; New York: Longman, 1986.

Bemis, Samuel Flagg. The Latin American Policy of the United States. New York: Harcourt, 1943.

Biles, Roger. A New Deal for the American People. DeKalb: Northern Illinois University Press, 1991.

Booth, Ken. Navies and Foreign Policy. London, New York: Croom, Helm, Crane, Russak, 1977.

Braisted, William Reynolds. Diplomats in Blue: U.S. Naval Officers in China, 1922-1933. New Perspectives on Maritime History and Nautical Archaeology. Gainesville: University Press of Florida, 2009.

Bushnell, David. Eduardo Santos and the Good Neighbor, 1938-1942. Latin American Monographs. Gainesville: University of Florida Press, 1967.

Carey, James C. Peru and the United States, 1900-1962. International Studies of the Committee on International Relations, University of Notre Dame. Notre Dame: University of Notre Dame Press, 1964.

Challener, Richard D. Admirals, Generals, and American Foreign Policy, 1898-1914. Princeton: Princeton University Press, 1973.

Chasteen, John C. Born in Blood and Fire: A Concise History of Latin America. 1st ed. New York: Norton, 2001. 
Child, John. Unequal Alliance: The Inter-American Military System, 1938-1978. Boulder: Westview Press, 1980.

Clayton, Lawrence A. Peru and the United States: The Condor and the Eagle. The United States and the Americas. Athens: University of Georgia Press, 1999.

Coleman, Bradley Lynn. Colombia and the United States: The Making of an Inter-American Alliance, 1939-1960. New Studies in U.S. Foreign Relations. Kent, OH: Kent State University Press, 2008.

Coletta, Paolo E. A Survey of U.S. Naval Affairs, 1865-1917. Lanham, MD: University Press of America, 1987.

Conn, Stetson, and Byron Fairchild. The Framework of Hemisphere Defense. United States Army in World War II: The Western Hemisphere. Washington, DC: Office of the Chief of Military History, Deptartment of the Army, 1960.

Cooper, John Milton. Woodrow Wilson: A Biography. 1st ed. New York: Alfred A. Knopf, 2009.

Cressman, Robert. USS Ranger: The Navy's First Flattop from Keel to Mast, 1934-46. 1st ed. Washington, D.C.: Brassey's, 2003.

Cross, Robert F. Sailor in the White House: The Seafaring Life of FDR. Annapolis: Naval Institute Press, 2003.

Dallek, Robert. Franklin D. Roosevelt and American Foreign Policy, 1932-1945: With a New Afterword. New York: Oxford University Press, 1995.

DeConde, Alexander. Herbert Hoover's Latin-American Policy. New York,: Octagon Books, 1970.

Dozer, Donald. Are We Good Neighbors? Gainesville: University of Florida Press, 1959.

Drake, Paul W. The Money Doctor in the Andes: The Kemmerer Missions, 1923-1933. Durham: Duke University Press, 1989.

Farcau, Bruce W. The Ten Cents War: Chile, Peru, and Bolivia in the War of the Pacific, 1879-1884. Westport: Praeger, 2000.

Ferrell, Robert H. American Diplomacy in the Great Depression: Hoover-Stimson Foreign Policy, 1929-1933. New York: W.W. Norton \& Company, Inc., 1970.

Francis, Michael J. The Limits of Hegemony: United States Relations with Argentina and Chile During World War II. International Studies of the Committee on International Relations, University of Notre Dame. Notre Dame, IN: University of Notre Dame Press, 1977.

Friedman, Max Paul. Nazis and Good Neighbors: The United States Campaign against the Germans of Latin America in World War II. Cambridge; New York: Cambridge University Press, 2003.

Gardner, Lloyd C. Economic Aspects of New Deal Diplomacy. Madison: University of Wisconsin Press, 1964. 
Gilderhus, Mark T. Pan American Visions: Woodrow Wilson in the Western Hemisphere, 1913-1921. Tucson: University of Arizona Press, 1986.

Grimmett, Richard F. Instances of Use of United States Armed Forces Abroad, 1798-2009. Vol. RL32170, Washington, DC: Congressional Research Service, 2010.

Hagan, Kenneth J. This People's Navy: The Making of American Sea Power. New York: Free Press, 1991.

Hart, Justin. Empire of Ideas: The Origins of Public Diplomacy and the Transformation of U.S. Foreign Policy. Oxford: Oxford University Press, 2013.

Healy, David. "Admiral William B. Caperton: Proconsul and Diplomat." Chap. 3 In Behind the Throne: Servants of Power to Imperial Presidents, 1898-1968, edited by Thomas J. McCormick and Walter LaFeber. 67-100. Madison: University of Wisconsin Press, 1993.

- Drive to Hegemony: The United States in the Caribbean, 1898-1917. Madison: University of Wisconsin Press, 1988.

- Gunboat Diplomacy in the Wilson Era: The U.S. Navy in Haiti, 1915-1916. Madison: University of Wisconsin Press, 1976.

—. James G. Blaine and Latin America. Columbia: University of Missouri Press, 2001.

Hoganson, Kristin L. Fighting for American Manhood: How Gender Politics Provoked the Spanish-American and Philippine-American Wars. Yale Historical Publications. New Haven: Yale University Press, 1998.

Holmes, James R. Theodore Roosevelt and World Order: Police Power in International Relations. 1st ed. Washington, D.C.: Potomac Books, 2006.

Howarth, Stephen. To Shining Sea: A History of the United States Navy, 1775-1991. 1st ed. New York: Random House, 1991.

Johnson, John J. A Hemisphere Apart: The Foundations of United States Policy toward Latin America. The Johns Hopkins Symposia in Comparative History. Baltimore: Johns Hopkins University Press, 1990.

Karsten, Peter. The Naval Aristocracy: The Golden Age of Annapolis and the Emergence of Modern American Navalism. 1st Naval Institute Press pbk. ed. Annapolis: Naval Institute Press, 2008.

Kirkland, Robert O. Observing Our Hermanos De Armas: U.S. Military Attachés in Guatemala, Cuba, and Bolivia, 1950-1964. Latin American Studies: Social Sciences and Law. New York, N.Y.: Routledge, 2003.

Klarén, Peter F. Peru: Society and Nationhood in the Andes. Latin American Histories. New York: Oxford University Press, 2000.

Knock, Thomas J. To End All Wars: Woodrow Wilson and the Quest for a New World Order. New York: Oxford University Press, 1992.

Krenn, Michael L. U.S. Policy toward Economic Nationalism in Latin America, 1917-1929. America in the Modern World. Wilmington: SR Books, 1990. 
LaFeber, Walter. Inevitable Revolutions: The United States in Central America. 1st ed. New York: Norton, 1983.

- The New Empire: An Interpretation of American Expansion, 1860-1898. Ithaca: Cornell University Press, 1963.

Lambert, Nicholas A. Sir John Fisher's Naval Revolution. Studies in Maritime History. Columbia: University of South Carolina Press, 1999.

Langley, Lester D. America and the Americas: The United States in the Western Hemisphere. The United States and the Americas. Athens: University of Georgia Press, 1989.

- The Americas in the Age of Revolution, 1750-1850. New Haven: Yale University Press, 1996.

- The Banana Wars: United States Intervention in the Caribbean, 1898-1934. Wilmington: Scholarly Resources, Inc., 2002.

Lehman, Kenneth D. Bolivia and the United States: A Limited Partnership. The United States and the Americas. Athens: University of Georgia Press, 1999.

Leonard, Thomas M. Central America and the United States: The Search for Stability. The United States and the Americas. Athens: University of Georgia Press, 1991.

Leuchtenburg, William Edward. Franklin D. Roosevelt and the New Deal, 1932-1940. The New American Nation Series. [1st ed. New York: Harper \& Row, 1963.

- Herbert Hoover. The American Presidents Series. 1st ed. New York: Times Books, 2009.

Long, David F. Gold Braid and Foreign Relations: Diplomatic Activities of U.S. Naval Officers, 1798-1883. Annapolis: Naval Institute Press, 1988.

Loveman, Brian. No Higher Law: American Foreign Policy and the Western Hemisphere since 1776. Chapel Hill: University of North Carolina Press, 2010.

Mahan, A. T. The Influence of Sea Power Upon History, 1660-1783. New York: Dover Publications, 1987.

Marolda, Edward J. FDR and the U.S. Navy. The Franklin and Eleanor Roosevelt Institute Series on Diplomatic and Economic History. 1st ed. New York: St. Martin's Press, 1998.

Masterson, Daniel M. The History of Peru. The Greenwood Histories of the Modern Nations. Westport: Greenwood Press, 2009.

- Militarism and Politics in Latin America: Peru from Sánchez Cerro to Sendero Luminoso. Contributions in Military Studies. New York: Greenwood Press, 1991.

Masterson, Daniel M. and Jorge Ortiz-Sotelo. "Peru: International Developments and Local Realities." In Latin America During World War II, edited by Thomas M. and John F. Bratzel Leonard. 126-43. New York: Rowman \& Littlefield, 2007.

McBride, William M. Technological Change and the United States Navy, 1865-1945. Johns Hopkins Studies in the History of Technology. Baltimore: Johns Hopkins University Press, 2000. 
McCullough, David. The Path between the Seas: The Creation of the Panama Canal, 18701914. New York: Simon \& Schuster, 1977.

Murray, Williamson, and Allan Reed Millett. A War to Be Won: Fighting the Second World War. Cambridge: Belknap Press of Harvard University Press, 2000.

Ninkovich, Frank A. The Wilsonian Century: U.S. Foreign Policy since 1900. Chicago: University of Chicago Press, 1999.

O'Connell, Robert L. Sacred Vessels: The Cult of the Battleship and the Rise of the U.S. Navy. Boulder: Westview Press, 1991.

Ortíz Sotelo, Jorge. Apuntes Para La Historia De Los Submarinos Peruanos. Lima: Biblioteca Nacional del Perú y Asociación de Historia Marítima y Naval Iberoamericana, 2001.

. "Captain Davy and the U.S. Naval Mission in Peru, 1920-1930." In New Interpretations in Naval History: Selected Papers from the Ninth Naval History Symposium Held at the United States Naval Academy, 18-20 October, 1989, edited by William R. Roberts and Jack Sweetman. 57-66. Annapolis: Naval Institute Press, 1991.

—. Escuela Naval Del Perú: Historia Ilustrada. La Punta-Callao: Escuela Naval del Perú, 1981.

Paullin, Charles Oscar. Diplomatic Negotiations of American Naval Officers, 1778-1883. Baltimore: Johns Hopkins Press, 1912.

Payan, Tony. Cops, Soldiers, and Diplomats: Explaining Agency Behavior in the War on Drugs. Lanham: Lexington Books, 2006.

Pérez, Louis A. Cuba: Between Reform and Revolution. Latin American Histories. 2nd ed. New York: Oxford University Press, 1995.

Pike, Fredrick B. FDR's Good Neighbor Policy: Sixty Years of Generally Gentle Chaos. 1st ed. Austin: University of Texas Press, 1995.

- The Modern History of Peru. Praeger Histories of Latin America. New York: Praeger, 1967.

—. The United States and the Andean Republics: Peru, Bolivia, and Ecuador. The American Foreign Policy Library. Cambridge: Harvard University Press, 1977.

Renda, Mary A. Taking Haiti: Military Occupation and the Culture of U.S. Imperialism, 1915-1940. Chapel Hill: University of North Carolina Press, 2001.

Roberts, William R., and Jack Sweetman. New Interpretations in Naval History: Selected Papers from the Ninth Naval History Symposium Held at the United States Naval Academy, 18-20 October 1989. Annapolis: Naval Institute Press, 1991.

Rock, David. "War and Postwar Intersections: Latin America and the United States." In Latin America in the 1940s: War and Postwar Transitions, edited by David Rock. xiv, 302 p. Berkeley: University of California Press, 1994. 
Roorda, Eric. The Dictator Next Door: The Good Neighbor Policy and the Trujillo Regime in the Dominican Republic, 1930-1945. American Encounters/Global Interactions. Durham: Duke University Press, 1998.

Roosevelt, Franklin D., and Samuel I. Rosenman. The Public Papers and Addresses of Franklin D. Roosevelt. 13 vols. Vol. 2, New York: Russell \& Russell, 1969.

Rosenberg, Emily S. Financial Missionaries to the World: The Politics and Culture of Dollar Diplomacy, 1900-1930. Cambridge: Harvard University Press, 1999.

- Spreading the American Dream: American Economic and Cultural Expansion, 1890-1945. American Century Series. 1st ed. New York: Hill and Wang, 1982.

Sater, William F. Andean Tragedy: Fighting the War of the Pacific, 1879-1884. Studies in War, Society, and the Military. Lincoln: University of Nebraska Press, 2007.

Scheina, Robert L. Latin America's Wars: The Age of the Professional Soldier, 1900-2001. 1st ed. Washington, D.C.: Brassey's, 2003.

- Latin America: A Naval History, 1810-1987. Annapolis: Naval Institute Press, 1987.

Schmitz, David F. Henry L. Stimson: The First Wise Man. Biographies in American Foreign Policy. Wilmington: Scholarly Resources, Inc., 2001.

Schoultz, Lars. Beneath the United States: A History of U.S. Policy toward Latin America. Cambridge: Harvard University Press, 1998.

Schroeder, John H. Shaping a Maritime Empire: The Commercial and Diplomatic Role of the American Navy, 1829-1861. Westport: Greenwood Press, 1985.

St. John, Ronald Bruce. The Foreign Policy of Peru. Boulder: L. Rienner Publishers, 1992.

Stallings, Barbara. Banker to the Third World: U.S. Portfolio Investment in Latin America, 1900-1986. Studies in International Political Economy. Berkeley: University of California Press, 1987.

Stavridis, James. Partnership for the Americas: Western Hemisphere Strategy and U.S. Southern Command. Washington, D.C.: National Defense University Press, 2010.

Tierney, Dominic. FDR and the Spanish Civil War: Neutrality and Commitment in the Struggle That Divided America. American Encounters / Global Interactions. Durham: Duke University Press, 2007.

Tulchin, Joseph S. The Aftermath of War: World War I and U.S. Policy toward Latin America. New York: New York University Press, 1971.

Utz, Curtis A. Cordon of Steel: The U.S. Navy and the Cuban Missile Crisis. The U.S. Navy in the Modern World Series. Washington: Naval Historical Center, 1993.

Venn, Fiona. The New Deal. Baas Paperbacks. Edinburgh: Edinburgh University Press, 1998.

Willmott, H. P. The Battle of Leyte Gulf: The Last Fleet Action. Bloomington: Indiana University Press, 2005. 
Wood, Bryce. The Dismantling of the Good Neighbor Policy. 1st ed. Austin: University of Texas Press, 1985.

- The Making of the Good Neighbor Policy. New York: Columbia University Press, 1961.

Yerxa, Donald A. Admirals and Empire: The United States Navy and the Caribbean, 18981945. Columbia: University of South Carolina Press, 1991.

\section{Journal Articles:}

Andrade, Ernest. "Submarine Policy in the United States Navy, 1919-1941." Military Affairs 35, no. 2 (1971): 50-56.

Friedman, Max Paul. "Retiring the Puppets, Bringing Latin America Back In: Recent Scholarship on United States-Latin American Relations." Diplomatic History 27, no. 5 (2003): 621-36.

Goldberg, Joyce S. "Consent to Ascent: The Baltimore Affair and the U.S. Rise to World Power Status." The Americas 41, no. 1 (July, 1984 1984): 21-35.

Lears, T. J. Jackson. "The Concept of Cultural Hegemony: Problems and Possibilities." The American Historical Review 90, no. 3 (1985): 567-93.

Millett, Richard. "The State Department's Navy: A History of the Special Service Squadron, 1920-1940." The American Neptune 35 (April 1975): 118-38.

Ortíz Sotelo, Jorge. "Las Rebelliones Navales Del Callao, 1932 y 1948." Apuntes 45, Segundo Semestre (1999): 83-95.

Sater, William F. "Revisiting the Battle of Iquique." History Compass 5, no. 1 (2007): 21826.

Stewart, Edward C. "American Advisors Overseas." Military Review 45, no. 2 (February, 1965 1965): 3-9.

Zeiler, Thomas, Brian McAllister Linn, Jennifer D. Keene, Phyllis L. Soybel, and Mark A. Stoler. "The Convergence of Military and Diplomatic History: A Roundtable." Passport: Newsletter of the Society for Historians of American Foreign Relations (September 2012): 30-37.

\section{Theses and Dissertations:}

Gerlach, Allen. "Civil-Military Relations in Peru: 1914-1945." Ph.D. diss., University of New Mexico, 1973.

Pope, Sharon S. "Harold B. Grow and the Establishment of Aviation in Peru, 1924-1930." M.A. Thesis, University of West Florida, 1973. 